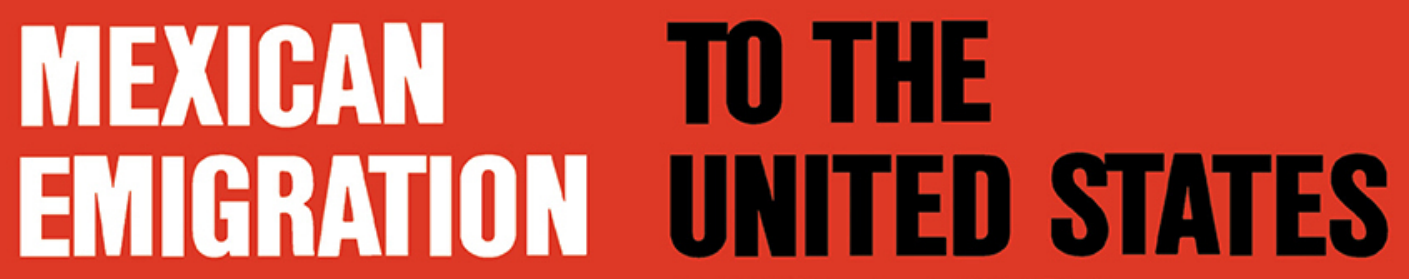

LAWRENCE A.CARDOSO

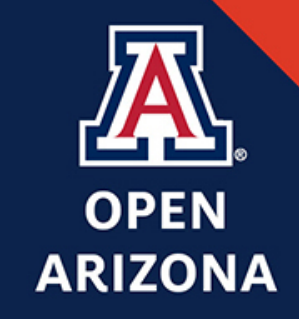





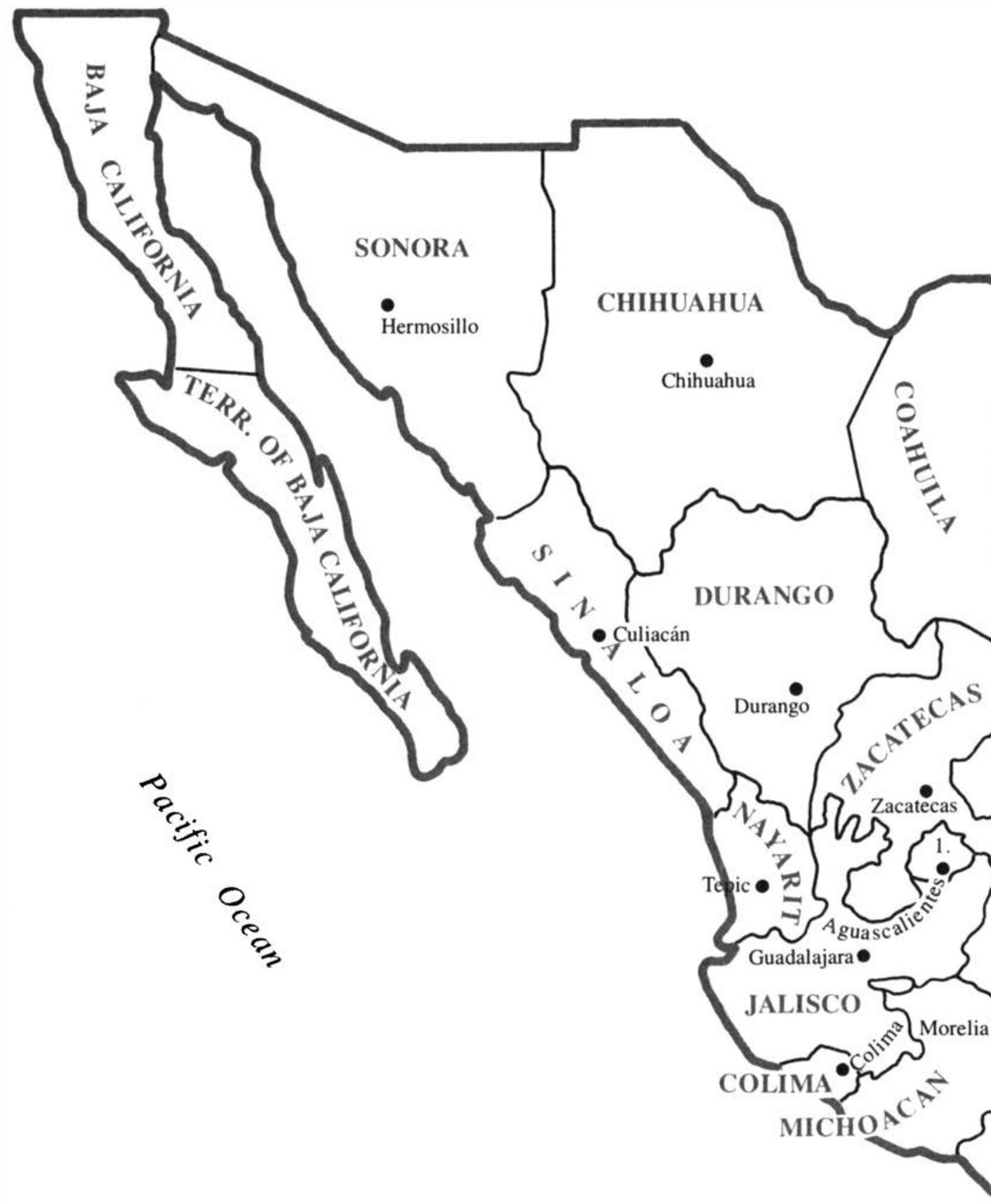

Mexico, 1931 



\section{Mexican Emigration to the \\ United States \\ 1897-1931}





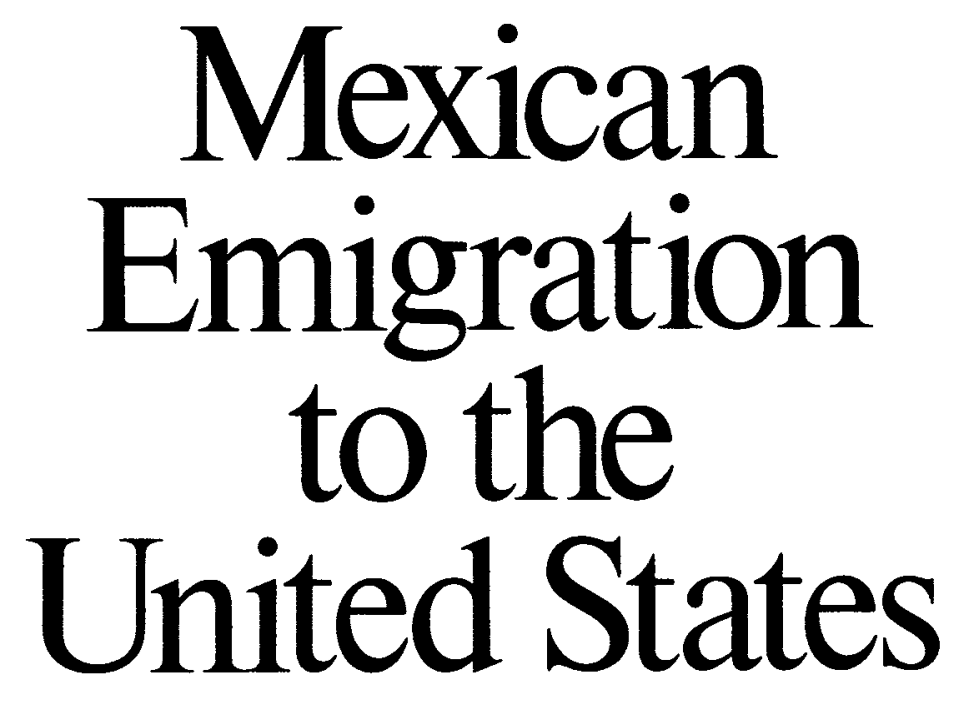

1897-1931

Socio-Economic Patterns

\section{Lawrence A. Cardoso}

THE UNIVERSITY OF ARIZONA PRESS 
About the Author...

LAWRENCE A. CARDOSO, a specialist in twentieth-century Mexican history, became a member of the history department of the University of Wyoming after receiving his Ph.D. from the University of Connecticut in 1974. His articles on Mexican immigration have appeared in various journals on southwestern and Mexican history.

This Open Arizona edition is funded by the National Endowment for the Humanities/ Andrew W. Mellon Foundation Humanities Open Book Program.

The University of Arizona Press

www.uapress.arizona.edu

Copyright (c) 1980 by The Arizona Board of Regents

Open-access edition published 2019

ISBN-13: 978-0-8165-4029-7 (open-access e-book)

The text of this book is licensed under a Creative Commons AttributionNonCommercial-NoDerivatives 4.0 International License (CC BY-NC-ND 4.0), https://creativecommons.org/licenses/by-nc-nd/4.0/.

Typographical errors may have been introduced in the digitization process.

The Library of Congress has cataloged the print edition as follows:

Cardoso, Lawrence A.

Mexican emigration to the United States, 1897-1931.

Bibliography: $\mathrm{p}$.

Includes index.

1. United States-Emigration and immigration-History. 2. Mexico-Emigration and immigration-History. 3. Mexicans in the United States-History. I. Title.

JV6798.M6C37 325’ '0973 79-20029

ISBN 0-8165-0678-7

ISBN 0-8165-0659-0 pbk. 
To the memory of my mother and father 



\section{Contents}

Preface xiii

Acknowledgments $\quad$ xvii

1. Porfirian Mexico: The Background of Massive Emigration 1

2. Emigration, 1897 to 1910: The Establishment $\begin{array}{ll}\text { of Patterns } & 18\end{array}$

3. Revolution and War, 1910 to 1921

4. Labor Emigration to the Southwest, 1910 to 1920: Mexican Attitudes 55

5. Floodtide of the 1920s 71

6. Mexican Policies and Attitudes in the 1920s: New Urgency 96

7. American Policy and Attitudes, 1918 to $1930 \quad 119$

8. The Great Depression: Emigration Halts and Repatriation Begins

Abbreviations $\quad 153$

Notes 154

Bibliographic Essay 179

Index 191 


\section{Maps}

Mexico, 1931

Mexican Railroads in 1880

Mexican Railroads by 1910 with Connections to

United States Lines

United States Railroad Pattern by 1900

\section{Tables}

1.1 Landholding in 1910

1.2 Mexican Population, 1793-1910 10

1.3 Daily Agricultural Wages and Wholesale Food Prices in the Central Plateau of Mexico

1.4 Emigrants From Native States, 1900-10

2.1 Daily Wages Available to Braceros in the United States, 1910-20

3.1 Legal Mexican Entrants Into the United States, 1910-20

5.1 Daily Wages Paid to Mexican Workers by Enterprises More Than 100 Miles From the Border, 1920-29

5.2 Mexican Immigrants in Selected States as of April 1, 1930

5.3 Legal Mexican Entrants Into the United States, 1920-29 


\section{Preface}

"Once I thought to write a history of immigrants in America," commented Oscar Handlin in The Uprooted. "Then I discovered that the immigrants were American history."*

An important segment of that history is the large numbers of Mexicans who began moving into the United States in the very late 1800 s. They were one of the successive waves of newcomers who helped transform an almost empty area into a powerful nation. Their coming coincided with the immigration of millions of "new" immigrants from southern and eastern Europe who came to the United States for similar reasons.

From 1897 to 1930 low-paid, unskilled workers were in strong demand in the United States, especially for agricultural work and railroad building. Simultaneously, events in Mexico created a large class of migrant workers. In view of the migrant's strong ties to their ancestral area, migratory patterns would not have emerged by the turn of the twentieth century without the existence of compelling factors in the Mexican society and economy. Circumstances in Mexico provided the initial impetus for the movement northward of campesinos and peones.

My major concern throughout this study is the people whom the Mexican novelist Mariano Azuela called "the underdogs" (los de abajo). This group of people comprised upward of 90 percent of Mexican immigrants to the United States from 1897 to 1930 . The history of middle- and upperclass immigrants forms another story, related to this one but not part of it. People in this second catagory were few in number, and their decision to

*Oscar Handlin, The Uprooted (Boston: Little, Brown and Company, 1951), p.3. 
remain in the United States hinged largely on the political attitudes of leaders in Mexico City.

Mexican immigration into what is now the United States started with the expedition of 1539 led by Fray Marcos de Niza and sponsored by Viceroy Antonio de Mendoza. Others had previously attempted to extend the effective territorial claims of the Spanish monarch to the north of Mexico City, but it was not until 1539 that the search for gold and souls was carried on in an organized manner with long-term effects. Niza was only the first of many thousands who came to the Borderlands from Mexico from the early sixteenth century to the late nineteenth century. Although these early population movements succeeded in establishing Spanish and Mexican settlements in the area from Louisiana to California and north to what is now the state of Colorado,* they were negligible in comparison with the myriads of Mexicans who came to the United States beginning in 1897.

External factors that affected emigration from Mexico at this time included governments, employers, church-affiliated individuals, revolutions, and civil wars. However, the internal psychological impetus to emigration was as important, if not more so, than the external stimuli. An integral part of my aim in this volume is to examine the human desire for self-improvement both as a factor with its own intrinsic merit and as a necessary complement to understanding the successes and failures of the established institutions. Institutional attainments were largely dependent on this human factor. All these phenomena help us to understand the continuing existence of Mexican emigration to the United States.

This study ends with 1931, but the Great Depression caused only a temporary suspension of immigration from Mexico. By 1940 the American economy had recovered partially from the severe dislocations of the early 1930s, and large numbers of Mexican workers began to come again in search of employment. The creation of the bracero program in 1942 served as a further inducement to emigration, just as the temporary program of World War I had done. During the twenty-two years of its existence more than 4,500,000 Mexicans crossed the border in order to work under the provisions of this bi-national treaty. Many times that number entered the United States illegally in search of work. When the program ended in 1964, conditions in both nations coupled with the revolution of rising expectations continued to contribute to large-scale emigration. There were an estimated three to six million wetbacks in the United States in the mid-seventies. $f$

\footnotetext{
* See John F. Bannon. The Spanish Borderlands Frontier, 1513-1821 (New York: Holt, Rinehart and Winston, 1971) for a sampling of the rich literature of the northward movement from Mexico in the colonial period.

†U.S. Congress, House Committee on the Judiciary, Illegal Aliens, 92nd Congress, Ist and 2nd sessions, 1971-72, 5 vols. (Washington: GPO, 1972), passim; Raul A. Fernandez, The United States-Mexico Border: A Politico-Economic Profile (Notre Dame: University of Notre Dame Press, 1977), p. 116.
} 
At the end of the seventies, Mexicans were still crossing the border to take advantage of the United States' higher standard of living. Unemployment and underemployment in Mexico remained high. As many as 5 million heads of families were without jobs; fully 50 percent of all Mexican families had an income of less than $\$ 50.00$ a month. In the United States, on the other hand, many American citizens spurned the low-paid jobs offered them. Yet the existence of a federally mandated minimum wage continued to exercise a strong attraction for restless braceros eager to seek their fortunes outside their homeland. Mexicans were expected to continue to come to the United States as long as this international imbalance existed.*

The size of the Mexican American community has increased steadily as a result. The 1930 census figure of $1,600,000$ climbed to $6,293,000$ in 1973 . If the latter figure is combined with the low estimate of 3 million illegal aliens, the total number of Mexican-descent people in the United States was well in excess of 9 million in 1973. It was probably considerably higher. The importance of this ethnic group was even greater than its size indicated because it was concentrated in the states of the Southwest. In the 1970s the populations of Texas, New Mexico, Arizona, California, and Colorado were on the average 12 percent Mexican and Mexican American, and, at points near the border, concentrations reached 80 percent. There were also hundreds of thousands of immigrants and their children in places such as Nebraska, Kansas, and Illinois. $\dagger$

The political, social, and economic conditions in the United States and Mexico affected the northward movement of Mexican laborers from 1897 to 1931. This is a study of the effects of assimilation, settlement patterns, and ethnic relations on the dynamics of emigration from the rule of Porfirio Díaz to the beginning of the Great Depression.

\section{LAWrence A. Cardoso}

\footnotetext{
*El Universal, June 2, 1972; Ifigenia Martínez de Navarrete, La distribución del ingreso y el desarrollo económico de México (Mexico: Instituto de Investigaciones Económicas de la Universidad Autonoma de Mexico, 1960), passim; Victor L. Urquidi, "Perfil general: economía y población," in El perfil de México en 1980, 3 vols.; 7th ed. (Mexico: Siglo Vientiuno, 1976), vol. 1, pp. 1-13.

†Arthur F. Corwin, "¿Quién Sabe?" in Corwin (ed.), (Immigrants-and Immigrants: Perspectives on Mexican Labor Migration to the United States (Westport: Greenwood Press, 1978), p. 128; U.S. Bureau of the Census, Statistical Abstract of the United States: 1975 (Washington: GPO, 1975). p. 34; Joan Moore, Mexican Americans (Englewood Cliffs: Prentice-Hall, Inc., 1970), pp. 52-54.
} 



\section{Acknowledgments}

I cannot give here the lengthy list of all the people who have provided assistance in preparing this study. However, I especially thank Hugh M. Hamill, Jr., who first interested me in the study of Mexico and Arthur F. Corwin who introduced me to the intricacies of Mexican emigration. Earlier versions of this work have been read and criticized by Michael C. Meyer, Stanley R. Ross, Rodney D. Anderson, Henry C. Schmidt, William H. Beezley, John M. Hart, and William Howard Moore. All provided valuable suggestions. Any errors of fact or interpretation which remain are entirely my own.

I am indebted to the staff members of the Archivo General de la Nación; Condumex, S.A.; the Secretaria de Relaciones Exteriores; the Hemeroteca; the National Archives; the libraries of the Universities of Connecticut, Texas, and Wyoming; Yale University; El Colegio de México; the Biblioteca de México.

Funding for research and compilation of this project has been provided by the Henry L. and Grace Doherty Foundation, the Ford Foundation, and the University of Wyoming. I thank them all for their aid and hope I have justified their confidence in me.

Marie L. Webner and her coworkers at the University of Arizona Press, which effected publication, assisted in the finalizing of the study and prepared the maps. They have never failed to show their commitment to the scholarly community.

The use of copyrighted materials was freely granted by the editors of the Southwestern Historical Quarterly, Historia Mexicana, and Indiana University Press. Songs of the Mexican migration are quoted from Puro Mexicano, edited by J. Frank Dobie (Austin: Texas Folklore Society, 1935).

My wife Arline never failed to provide the constant encouragement needed to complete this book. 



\section{Mexican \\ Emigration to the \\ United States \\ 1897-1931}




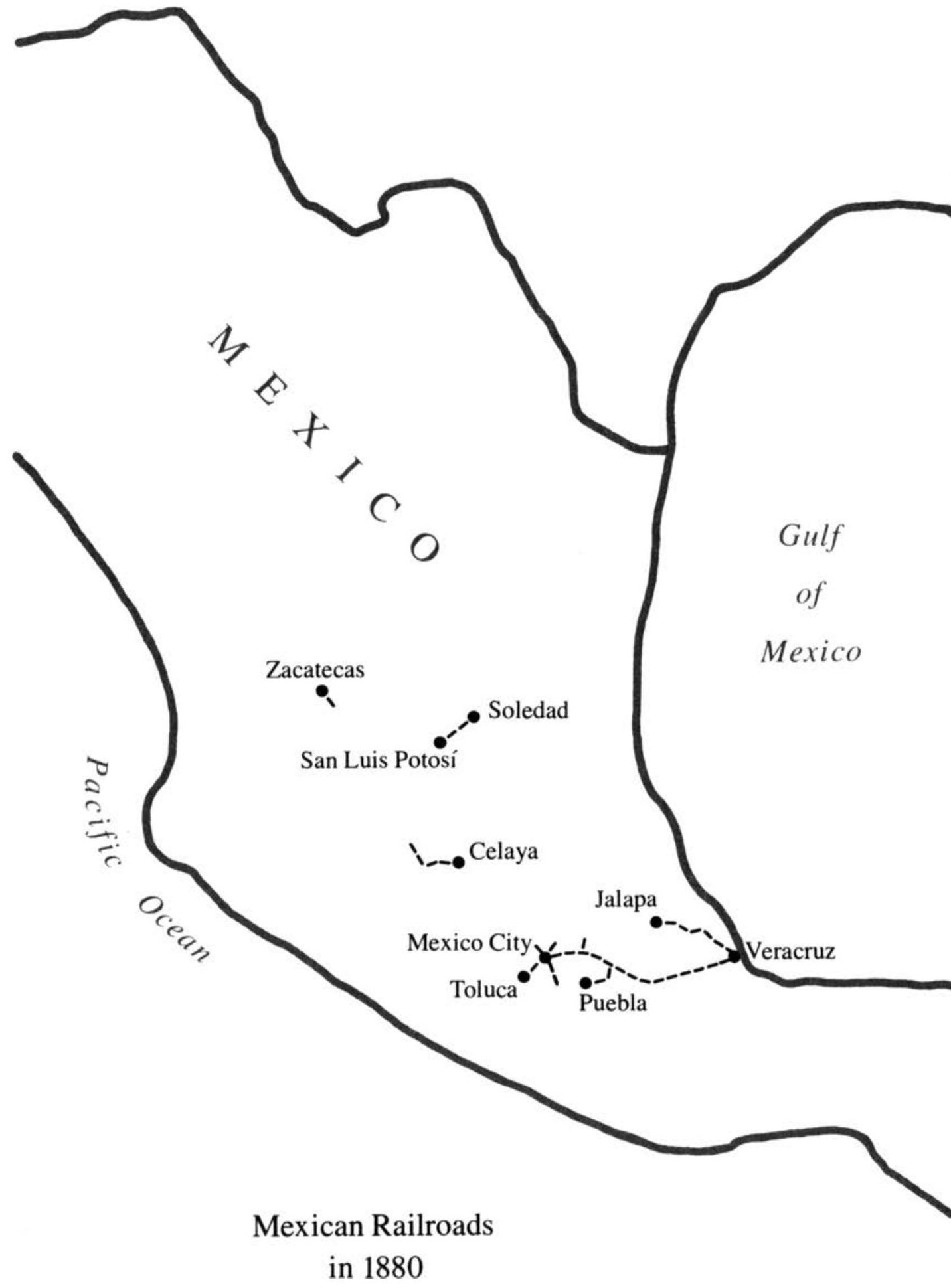




\section{Porfirian Mexico: The Background of Massive Emigration}

Many of the root causes of Mexican emigration to the United States resulted from rapid changes in the land and labor systems of rural Mexico in the 1890s. Before the institution of these government-sponsored programs, a substantial number of rural inhabitants lived, if not always comfortably or securely, on communally owned ejidos or on privately owned haciendas, both of which had as their main economic function the provisioning of nearby urban centers. The initial impetus for emigration resulted from attempts to achieve capitalist modernization of the countryside. Ejidos were destroyed so that the more efficient hacienda could grow vast quantities of export items such as coffee and sugar. Ejido dwellers, ejidatarios, were forced by the millions either to reside on new haciendas as workers or to join the migratory labor stream which supplied landowners with extra helpers at planting and harvesting times.

This enclosure process happened at the same time that other developments further worsened the standard of living of rural inhabitants. The new railway system helped destroy the ejidos because it allowed the export of luxury food items, which increased the value of the lands held by villagers in common. Real wages, never that high to begin with, declined because of a rapid population increase which provided employers with an oversupply of laborers. Food prices shot up because of the utilization of land for export crops. Living and working conditions on the hacienda steadily degenerated as owners and overseers, with the full support of the Porfirian government, put their profits into modernization schemes. The men, women, and children of rural Mexico paid a horribly disproportionate price to pull their country into the twentieth century. It was natural that they sought better conditions for 
themselves elsewhere. The northern part of their nation offered them a better alternative, but not the best, and a jumping-off point for the United States.

Mexican geography was a constant factor which pushed people from their native land. The central plateau area includes the country's most populous states, with population density ranging from twenty to sixty people per kilometer. México, Guanajuato, San Luis Potosí, Querétaro, Hidalgo, Jalisco, and Aguascalientes are some of the states in this region. They are ringed by mountains on the east, west and south; the north quickly gives way to relatively flat desert. Mountains and other land useless for agricultural production comprise about two-thirds of this core area. Only about 10 percent of the land can be used for the production of foodstuffs because of the paucity of fertile land and the frequent absence of timely rains. In states to the southwest of the central region such as Michoacán and Oaxaca there is insufficient crop land also because of the topography, and a heavy population density. These areas provided two-thirds of the emigrants to the United States, in part, because of their inability to support adequately the local populations. ${ }^{1}$

The emigrants' history in this period is largely one of rural people. Over 80 percent of the total Mexican population were of the rural lower classes in the latter part of the nineteenth century. Rural campesino villagers, those living in settlements of less than 2,500 people, engaged almost exclusively in farming and stockraising in an attempt to feed themselves. The home was the economic base of the family, given the nature of farming activity. All ablebodied members of the family unit were forced to work in an attempt to avoid starvation; the campesino family generally could not feed itself because of the poor quality of the land and the lack of technology and resources to improve production. One result of this situation was a steady migration of males in search of seasonal or casual employment to earn money to help meet family needs. ${ }^{2}$

This system of land use and labor was based on ancient Indian Mexican culture. Ejidos dotted the countryside throughout the central plateau region in the pre-Porfirian period. For hundreds of years under both Spain and independent Mexico campesinos had some recognized claim to village lands, or at least to land use. Most governments before the end of the nineteenth century had intentionally reinforced village cohesion by grants of land and protection of properties used as ejidos, with the purpose of making peasants more easily responsible for their taxes and other obligations to society. The communal response to this protection was the development or retention of a strong internal system of organization with marked ties to religious worship and, in many instances, pre-conquest Indian practices and beliefs. ${ }^{3}$

The prevalent form of land tenure in the late nineteenth century, however, was the large hacienda, which ranged in size from 45,000 to one million 
acres and often embraced peasant villages in a state of bondage. The landless peasantry were subjected to a nefarious socio-economic system. The acasillados, or resident peones, as well as migrant workers employed during planting and harvesting seasons, were often brutally exploited. In the words of contemporary critic Wistano Luis Orozco, most hacienda workers were still like Indian slaves, beasts of burden "destitute of illusion and all hope." 4

Debt peonage was one of the most onerous features of the hacienda during Porfirian times. Although this form of involuntary servitude was outlawed by the Constitution of 1857 and by state constitutions, it survived through sheer force of custom in most rural areas. Owners and administrators advanced money, food, seed, and supplies to their workers, usually through the tienda de raya, the company store. In many cases, the value of a given transaction exceeded the illiterate worker's monthly wage. Because of static income and manipulated accounts, these debts were rarely paid up. The force of ancient custom then bound sons to pay the debts of their fathers, unless, of course, they chose to run away.

The mechanisms of debt peonage had become a sophisticated form of legal entrapment by the turn of the century. Luis Cabrera, who spent many years as a schoolteacher on a hacienda and became an important spokesman for agrarian reform after 1910, explained how the system operated. Landowners traditionally extended credit to their workers three times a year on religious holidays. During Holy Week the worker could buy 3 to 5 pesos of new clothing for his family. On All Saints' Day he received a loan of 6 to 10 pesos. At Christmas a third loan rounded out the cycle. In addition, other periodic loans were made throughout the year. The resulting debt meant that the average bracero owed his employer 400 to 500 pesos at any given time when his salary averaged 120 pesos $(\$ 60.00$ U.S.) a year. This situation, Cabrera told his fellow congressmen in 1912, was the "forging of a chain [of slavery] which you all are aquainted with.", 5

Other harsh features of the hacienda system gave peon families additional reasons to flee. Rural isolation, coupled with governmental support of the proprietary class, allowed the landowners near-absolute control over acasillado and migrant peones. The classic indictment of the evils of Porfirian Mexico, first published in 1909 by Andrés Molina Enríquez, accused landowners and their administrators of exercising the absolute domination of a feudal lord. They, or the rural police, could mete out corporal punishment with impunity and execute workers and their families for real or supposed infractions of hacienda rules. Molina Enríquez continued, "With rare exceptions there is not a rural farm where those in charge (administrators and lessors) are not the terror of the poor, defenseless and ignorant campesinos. The sickness exists as a terrible gangrene which causes incalculable evil for the working class." 6 
Abuses were also common in dealings with sharecroppers and helped contribute to emigration. There were two major forms of this system of labor. The medieros al rajar furnished their own agricultural implements and animals and received 50 percent of the harvest, the other half going to the landowner. The medieros al quinto furnished only their labor and gave the usual half of the crop to the hacienda owner plus one-fifth of the remaining harvest in return for the use of machinery and animals. By the turn of the century the majority of medieros worked on the quinto system, and many were assessed extra fees either in the form of money or labor for the privilege of having access to land. Inevitably, sharecroppers took advances of money, food, and supplies from the company store as their real wages decreased, and many of them were quickly reduced to the status of peones. Karl Kearger, a German consul who studied Mexico's agricultural development extensively, wrote in 1901 that medieros at harvest time in Michoacán "not only received no corn but ended up in debt to the hacendado.' 7

The experience of Elías Garza in the early 1900s provides a typical instance of how this arrangement led to emigration. Garza began to work on the La Piedad hacienda in the state of Michoacán when he was a boy of twelve. When he reached the age of fifteen or sixteen, he contracted with the landowner to grow corn on shares. The owner provided the seed, animals, and land; Garza planted, tended, and harvested the crop with the expectation of receiving a percentage of it in return for his labor. At the end of the season, however, the landowner cheated Garza and refused to give him anything for his efforts. With no recourse except the "judicial appeal" of flight, Garza fled to El Paso, Texas, where he obtained employment as a railroad track laborer. ${ }^{8}$

Abject poverty dominated rural peasant existence. Generally, the entire peon family lived in a one-room shack made of reeds or bamboo in warmer climates and adobe in colder areas. Animals owned by the family often shared living quarters with them. Household and human wastes were thrown in a heap near the family dwelling and left to decompose or be eaten by animals. Water was often contaminated, and this, along with the many other unsatisfactory conditions, led to a high consumption of alcoholic beverages. ${ }^{9}$

The peon could do little with the amount of land available to him on the hacienda. Iron tools and animals to work the land were usually not to be found. His perennial foods were, above all, corn, the "staff of life," followed by beans, squash, and chili peppers. Meat, fish, eggs, or milk were unheard-of luxuries. Even the production of these meager food items declined as the Porfirian period wore on, in part because more and more land was taken from the peasantry and used to produce more profitable export items. From 1877 to 1907 corn production dropped by .84 percent each year while export crops climbed an estimated 4 percent every year. Total agricultural production rose only 3.1 percent in the same period and, in the three years before the 
Revolution of 1910 , actually decreased because of unfavorable weather and economic recession. ${ }^{10}$

These shifts in agricultural production brought great suffering to Gonzalo Plancarte and his father. In the late 1890 s both men were forced to leave the land they worked on because their cattle foraged in areas the hacienda owner wished to use for the production of export items. Since neither man was able to eke out an existence, both left their native state of Guanajuato and went to Michoacán. Once there, they remained only a short time in each place they stopped because landowners chased them away. They were soon forced to sell their animals for lack of grazing land to sustain them. The father died in 1900 and his son, reduced to the direst poverty, emigrated to the United States in search of work. ${ }^{11}$

The "Tyranny of Maize," as Lesley Byrd Simpson called this preColumbian pattern of heavy dependence on one crop, drove countless thousands of famished peasants from the areas of their birth. Centuries before the Spanish conquest in 1521 indigenous people had developed varieties of corn to feed themselves and their animals. The grain gradually became the most important crop in the area: its growing season coincided with the May to November seasonal rains; its protein content was high; and it kept well with little effort. Maize, however, exacted an insidious tribute for all its favorable qualities. It quickly exhausted soils and forced peasants to seek everexpanding fields to sustain new crops. The worst feature of corn culture was the people's overdependence on it. In times of flood, drought or early frost, there was simply nothing to take its place. During periods of adverse conditions, a slow but sure starvation descended upon the rural masses. What nature had done at random prior to the Porfirian period, men now did with a fixed purpose over an extended period of time. ${ }^{12}$

The hacienda peon had little hope but in flight. He ran away to other parts of Mexico or to the United States, often taking his family with him. At a distance from his home, who could discern his original status? No one could lay claim to his person: he was his own master and beyond the reach of the rural police and hacienda administrators. Little wonder that landowners frequently heard some of their workers shout that freedom awaited those who fled to the north. Migration was the only liberation. ${ }^{13}$

The campesino and peon family had good cause to flee the land by the turn of the century, but as if this were not enough, the regime of General Porfirio Díaz (1876-1911) sponsored a series of colonization schemes and land reforms that deprived almost all ejidatarios of their ancestral rights to whatever remained of their common lands. Mexican planners of the time sincerely believed that immigration into their country from northern and western Europe was one of the best ways to accelerate national development. It was hoped that white European colonists would plant the seeds of economic 
progress in the countryside and have a favorable influence on the "regressive' Indian and mestizo peasantry. The government's method of stimulating immigration was to offer public lands to would-be immigrants and immigrant impresarios. These "public lands"' were in reality the common lands of the campesinos, confiscated by the government. As one hacienda owner explained this form of racism in 1900, "The Indians are a burden which the Mexicans must carry; without education of any kind, they are a hindrance to progress, an obstacle to our advance .... We can not become great by ourselves; in order to produce more, we require the colonizing element."'14

The first step in this policy of forced development was the enactment in 1883 of a new land law. Under its provisions a private colonizing company would receive up to one-third of any land it surveyed and subdivided. The remaining land could then be bought at a very low rate. The rough dimensions of the ensuing land grab are as follows: by 1892, about one-fifth of Mexico's entire land area had passed into the hands of private land companies, and, by 1910, 27 percent of the country's "public" lands, totaling over 134,000,000 acres, had been alienated; in almost every state of the central plateau not one acre of land remained for the rural peasantry. Many ejidatarios, unable to prove their title to the newly surveyed and claimed lands, saw their lands swallowed up by the colonization companies. ${ }^{15}$

The next step taken by the government to rid rural areas of nonproductive economic units was the outright abolition of the ejido. The Constitution of 1857 had forbidden civil corporations to own any land at all. The theory of the Reform Liberals who wrote this document had been that individual proprietorship, as opposed to the communally owned ejido and Catholic Church land, was the most desirable precondition for capitalistic economic progress. The Constitution's provisions, however, had not been enforced until the publication of two Porfirian decrees in 1889 and 1890. All village-held land was ordered to be divided immediately into individually owned plots. The illiterate peasantry had little understanding of the concept of private property and quickly fell prey to land speculators and colonizing companies which bought the former village lands for a nominal sum. ${ }^{16}$

Colonization companies and hacienda owners employed other means to gain title to campesino lands. Until the latter part of the Porfiriato the hacienda and many ejido dwellers had coexisted without much notice of each other. Encroachments by private land owners had occurred throughout the centuries since the Spanish conquest, but there had been little coordinated effort on the part of hacienda owners to monopolize land at the expense of the ejido. This state of equilibrium changed rapidly after the introduction of the railway system in Mexico in the 1870 s and 1880s. New, lucrative markets for foodstuffs and raw materials in the United States and Europe developed because of the fast, economical transportation made available by the railroad system. Hacienda owners quickly realized that huge profits would accrue to 
them, and they took steps to modernize their properties by bringing in foreign technicians and new technology. They also sought to increase as much as possible the size of their holdings in order to maximize their sales and profits.

The Porfirian legal code gave entrepreneurs many other devices which could be used to destroy the ejidal system. Many landowners formed colonizing companies without any intention of encouraging European immigration, but only for the purpose of swallowing up nearby communal property. If a legal battle ensued, the burden of proving title fell to the villagers; because of the lack of legal funds to hire attorneys and pay court costs or the impossibility of proving title, many humble villagers had to abandon lands held in common for generations. Denunciation of title proved yet another tool for land monopolizers to gain title to ejido lands. Anyone could lay claim to occupied lands which did not have a registered title simply by going to local authorities and "denouncing" the pretended title of the land's inhabitants. The denouncer then paid a registration fee which put the title to the land in his name. Since communally owned properties were ipso facto illegal, they, along with vast areas of poorly surveyed land, were fair game for denunciation. Throughout the heavily populated central states hundreds of villages lost their land in this manner. One author has estimated that because of these Porfirian practices up to $5,000,000$ campesinos lost their rights to the use of ejido land. ${ }^{17}$

By the time of the Mexican federal census of 1910 there were so few ejidos left that enumerators did not bother to count them. The statistics collected did show the number of people who were completely landless (see Table 1.1).

TABLE 1.1

\section{Landholding in 1910}

\begin{tabular}{lcc}
\hline State & $\begin{array}{c}\text { Number of } \\
\text { Rural Families }\end{array}$ & $\begin{array}{c}\text { Families Without } \\
\text { Land, \% }\end{array}$ \\
\hline Durango & 81,515 & 96.8 \\
Guanajuato & 155,289 & 97.1 \\
Hidalgo & 118,159 & 98.7 \\
Jalisco & 186,447 & 96.2 \\
México & 166,269 & 99.5 \\
Michoacán & 165,789 & 97.3 \\
Puebla & 179,324 & 99.3 \\
Querétaro & 40,042 & 98.4 \\
San Luis Potosí & 97,779 & 98.2 \\
Zacatecas & 81,243 & 98.1 \\
\hline
\end{tabular}

Adapted from census figures in George McBride, The Land Systems of Mexico, (New York: American Geographical Society, 1923), p. 154. 
The experience of the village of Naranja, in central Michoacan, typified the experience of many peasant ejido holdings. This Tarascan area had remained semi-isolated because of its high mountains, limited arable land, and geographical remoteness. Naranjeños had lived unmolested by their nominal Spanish and Mexican overlords except for an occasional tax collector. Naranja's economy was intimately related to the nearby swampy lake of Zacapu. In 1885 the lake and village, with its several hundred inhabitants, comprised an area of about 3,000 acres. The villagers exploited the marshy lake through their hunting, fishing, and collecting activities. Men, women, and children collected clams, lizards, and roots, and hunted frogs, ducks, and other wildlife. Nearby trees provided wood, fruit, and roots used to prepare several types of soup. All of these items supplemented the cultivated crops of corn, chili, squash, and beans. Overall, the diet was nutritious and fairly well balanced. ${ }^{18}$

The ejidatorios' intricate relationship with the soil and lake came to an abrupt end soon after 1885. In 1881, surveyors discovered a black soil of rare fertility under the Zacapu marsh. Two years later, two Spanish investors, the Noriega brothers, entered into negotiations with the national government to claim the area in accordance with new colonization laws. One-third of the land was granted outright to them, and the remainder sold for a pittance. The village of Naranja retained only a small strip of land which, by itself, was insufficient to sustain the local inhabitants.

The Noriegas completely drained the lake and planted the soil to com by 1900. The yearly harvest, conservatively estimated in excess of 400,000 bushels, was sold to urban area markets around Mexico City after being transported there on a railroad built by the Spaniards. Catastrophic changes resulted for the Naranjeños. Alongside the new-found opulence of the two brothers was a threat of starvation for the villagers. The artificial desiccation of the lake brought about a sharp reduction in daily caloric intake. Weeds and wild flowers from the surrounding mountains became the primary food for those with little or no land to grow crops on. The most intense crisis afflicted the people: possible death by starvation.

The response of the villagers further helped to eradicate all vestiges of their once-comfortable existence. The families with oxen and plows left the village to work on the Noriega hacienda. Many individuals who owned small private plots of land were forced to sell them as the land alone could not sustain them. As late as 1921, before the restitution of ejidal lands, the few remaining landowners were producing only a "laughable quantity" of corn according to a government inspector. Emigration was another response of the Naranjeños. Approximately one-third of the village's people gained employment as migrant laborers on haciendas throughout Mexico; an intensive emigration to the United States also took place. The inhabitants of Naranja had been forced abruptly from their traditional local economy and culture, de- 
veloped through the centuries in an intimate relationship with the land, in a classic sequence of ejido destruction. By 1900 , the vast majority of the villagers were members of a large, impersonal, and hard-pressed labor force migrating in search of work. ${ }^{19}$

An exhaustive study of the inhabitants of the Valley of Teotihuacán, carried out in 1917 under the direction of Manuel Gamio, provides a unique quantitative insight into the conditions brought about by the destruction of the ejido system. Field workers systematically studied 8,330 persons in that area which lies to the north-northwest of Mexico City and encompasses parts of the states of Hidalgo, Puebla, México, and Tlaxcala as well as a section of the Federal District. Although fieldwork was carried out after the Porfiriato, Gamio made it clear that the conditions his group found had come into existence before 1910 and had been little affected by revolutionary events since that date.$^{20}$

The peasants showed a remarkable persistence of pre-Hispanic traits. Their language and food habits were those of the Indians who had lived in the area 500 years before. Their living styles reflected, in the opinion of the study team, many shortcomings. Housing, for example, was found to consist of a one-room building, or jacal, made of clay walls and a straw roof. Many people lacked even these minimal conditions and were found living in caves. Hygienic standards were noted as "completely deplorable." Starvation was endemic to the area. In optimal years, when maize received abundant and timely rains, peasants could count on 500 grams of corn a day per person. This amount was insufficient for a child's proper nutrition. ${ }^{21}$

So thoroughgoing was the destruction of the ejidos and the creation of misery by the process that Andrés Molina Enríquez was moved to remark in 1909 that there was no need to recapitulate these well known events. It was, however, "painful to realize that the Republic has been less than just to the ejidos while they were respected during the period of Spanish domination. It is even more painful to reflect that if the latter recognized their right to exist-if only because they existed before the conquest-the former has not considered that fact, or the fact of 400 years of possession to be of sufficient weight for their continued existence.",22

Increased population also exacerbated land shortages and rural misery. Available statistics are far from precise, but their overall import is quite clear. Until the last quarter of the nineteenth century population growth was very slow. Numerous revolutions, beginning with the revolt of Father Miguel Hidalgo in 1810 , coupled with economic and social displacements, had caused a high death rate in Mexico. This situation changed after 1876 with the establishment of the "Porfirian peace" along with some advances in public health measures. The result was a sharp rise in the survival rate so that from 1875 to 1910 population increased by more than 50 percent, adding almost $6,000,000$ people to a subsistence economy. Demographic increases were 
disproportionately higher in some of the central plateau states. Michoacán's population rose by 105 percent in the period from 1895 to 1910; in Puebla and Querétaro the number of people increased by 140 percent. Indeed, population growth was so great that the economy's inability to absorb new workers caused a slowdown of all economic growth.$^{23}$ Table 1.2 shows the magnitude of the Porfirian increases.

The impact of this marked increase in population has rarely been appreciated by critics of the Porfirian regime. A labor surplus helps explain the phenomenon of static wages and rising food prices. The Porfirian government supported policies of classic economic liberalism when it came to the position of workers in the economy. Labor was, therefore, just another commodity whose price was set by market laws of supply and demand. Why should employers pay in wages any more than the amount determined by the free market system? There were usually several people looking for any one job, and this fact allowed hacienda owners to depress or at least not raise wages. At no time during the thirty years preceeding the Revolution of 1910 did the daily agricultural wage exceed $\$ .15$ a day. One worker told Manuel Gamio in the 1920s that his pay on a hacienda in Zacatecas at the turn of the century was "so little that I don't even remember how much it was." The trend of food prices was in sharp contrast to the rural wage structure (see Table 1.3). The cost of corn and beans rose quickly because of the country's expanding population and the decline of staples for local consumption. ${ }^{24}$

TABLE 1.2

Mexican Population, 1793-1910

\begin{tabular}{cc}
\hline Year & Total Population \\
\hline 1793 & $5,450,000$ \\
1803 & $6,225,000$ \\
1810 & $6,122,000$ \\
1820 & $6,204,000$ \\
1831 & $6,382,000$ \\
1840 & $7,016,000$ \\
1850 & $8,000,000$ \\
1861 & $8,212,000$ \\
1875 & $9,495,000$ \\
1880 & $10,448,000$ \\
1895 & $12,632,000$ \\
1900 & $13,607,000$ \\
1910 & $15,160,000$ \\
\hline
\end{tabular}

Adapted from Charles Cumberland, Mexico: The Struggle for Modernity (New York: Oxford University Press, 1968), pp. 367 and 204; and Luis González y González et al., La República restaurada: La vida social, vol. 3 of Historia moderna de México, ed. Daniel Cosío Villegas (Mexico: Editorial Hermes, 1956), pp. 50-52. 
Although to date there has been no comparable comprehensive survey of retail prices, the evidence available indicates they rose just as fast as wholesale indicators. One study, carried out by the International Bureau of American Republics, showed a 50 percent rise in the retail price of corn during the 1877 to 1903 period. Mexican commercial surveys showed a similar price increase for the latter part of the Porfiriato. By 1910 the lower classes, rural and urban, had to spend almost their entire income to provide themselves with a bare subsistence diet consisting mostly of corn and beans. Economist Walter Weyl explained in 1902 the effect of shrinking real wages and rising food prices in the following terms:

The wages received by Mexican employees, whether agricultural or industrial, actually suffice for the bare maintenance of life and for real increase in the population. It is therefore self-evident that the cost of living is less than the wages received. The conclusion to be deduced from this fact, however, is merely that the Mexican laborer consumes very much less, and not, as has been too frequently assumed, that the individual article of consumption costs less.

TABLE 1.3

Daily Agricultural Wages and Wholesale Food Prices in the Central Plateau of Mexico, in Pesos

\begin{tabular}{cccc}
\hline & & Corn & \\
\cline { 3 - 3 } Year & Wages & Cost of 100 Kilos & Cost of 100 Kilos \\
\hline 1890 & 0.25 & 3.6 & 6.9 \\
1895 & 0.30 & 3.9 & 6.0 \\
1900 & 0.27 & 4.0 & 5.0 \\
1901 & 0.25 & 4.7 & 6.6 \\
1902 & 0.25 & 4.8 & 8.9 \\
1903 & 0.28 & 4.0 & 6.0 \\
1904 & 0.27 & 4.2 & 6.6 \\
1905 & 0.24 & 5.4 & 7.6 \\
1906 & 0.22 & 6.0 & 9.2 \\
1907 & 0.23 & 6.0 & 10.1 \\
1908 & 0.23 & 6.0 & 10.4 \\
\hline
\end{tabular}

Adapted from Colegio de México, Estadísticas económicas del Porfiriato (Mexico: Colegio de México, n. d.), pp. 148, 156-59.

Molina Enríquez, in more prosaic terms, lamented in 1909 that rural wages available provided braceros with "neither tortillas with salt or cotton clothing," or decent housing. He concluded that the "currents which are carrying our working population to the United States" will continue to snatch up Mexicans and carry them across the border. ${ }^{25}$ 
Inflationary conditions had the effect of forcing large numbers of the rural population into the migrant labor stream in search of money with which food could be purchased. This process was most notable in the heavily populated central plateau states. The high population densities, land shortages, hacienda brutality, and depressed wages were prime factors in encouraging the emergence of a migrant labor class. Hundreds of thousands of braceros yearly left their native states to look for work elsewhere. This startling and unexpected result of national colonization laws led essayist Genaro Raigosa to note in 1910 that the hacienda had unfortunately been the "most effective instrument for the depopulation of [rural] territory.",26

The following statistics shown in Table 1.4 probably represent only a fraction of the migrant labor force because of the inherent difficulties in counting such a mobile group.

TABLE 1.4

Emigrants From Native States, 1900-10

\begin{tabular}{lccrrr}
\hline & \multicolumn{2}{c}{1900} & & \multicolumn{2}{c}{1910} \\
\cline { 2 - 3 } \cline { 5 - 6 } States & $\begin{array}{c}\text { Absolute } \\
\text { No. }\end{array}$ & $\begin{array}{c}\text { Percent of State } \\
\text { Population }\end{array}$ & & $\begin{array}{c}\text { Absolute } \\
\text { No. }\end{array}$ & $\begin{array}{c}\text { Percent of State } \\
\text { Population }\end{array}$ \\
\hline Guanajuato & 77,263 & 8.86 & & 102,696 & 9.75 \\
Hidalgo & 39,513 & 4.53 & & 56,455 & 5.36 \\
Jalisco & 98,408 & 11.29 & & 97,386 & 9.25 \\
México & 151,037 & 17.32 & & 142,169 & 13.50 \\
Michoacán & 30,522 & 3.50 & & 48,802 & 4.64 \\
Puebla & 64,260 & 7.37 & & 66,825 & 6.35 \\
San Luis Potosi & 68,298 & 7.83 & & 83,011 & 7.89 \\
Zacatecas & 84,970 & 9.74 & & 112,949 & 10.73 \\
\hline
\end{tabular}

Adapted from González Navarro, La vida social, p. 27.

These conditions of unrest, insecurity, and geographical mobility worsened greatly during the last few years of the Porfirian period. In 1905 and 1906 Mexico lost part of her food and export crops because of drought. In 1907 , and for the next few years, crop losses were almost total in some areas because of continuing lack of rain. The worldwide recession which struck in the latter year also helped to lower the standard of living in Mexico because of the decline in the volume of food and material exports. In an attempt to compensate for this trading imbalance, Díaz's government lowered wages for workers so as to increase the sale of Mexican export items. ${ }^{27}$

The migratory labor stream directed itself primarily toward northern Mexico in order to escape increasingly distressful conditions in the central part of the nation. For this reason, certain developments in the north deserve a brief explanation. The Mexican government had long sought to promote settlement in the border zone with the United States. States such as Nuevo 
León, Tamaulipas, Chihuahua, Coahuila, and Sonora went into an economic decline after 1848 because the new boundary with the United States created by the Treaty of Guadalupe Hidalgo cut off their normal trading patterns with Texas, New Mexico and California. To counteract this stagnation and frustrate possible new losses, the Mexican government in 1861 created a free zone along the border. The new law allowed the duty-free importation of consumer goods destined for Tamaulipas. The resulting prosperity was quick and striking. Prices for consumer items fell below prices for the same goods in the United States, and hundreds of Mexicans returned from Texas to their own country to take advantage of the new affluence. Many Mexicans in the central part of the country then migrated to the northern states to enjoy the generally lower cost of living there. Soon thereafter, a large-scale contraband trade into Texas developed because of the American market for low-priced Mexican goods. ${ }^{28}$

Railroad construction further stimulated northern prosperity and at the same time tapped the large pool of laborers in central Mexico. It was primarily because of the railway system that braceros were able to seek opportunities for themselves outside their native areas. Ironically, the same transportation system that made ejido land more tempting to speculators and luxury export items more profitable for landowners also provided the dispossessed with an avenue of escape from the strange new world of Porfirian capitalists. Díaz's government sought to bind the country's political center with the northern frontier and gave special emphasis to railroad construction in the 1880s. One of the most important north-south links was the Mexican Central Railroad. It opened regular passenger service and freight service from Mexico City to Ciudad Porfirio Díaz in Coahuila on April 10, 1884. Later, the construction of spur lines and the acquisition of smaller railroad companies resulted in the company's deep penetration into the populous states of the central plateau. By 1894 the Mexican Central crossed the states of México, Hidalgo, Querétaro, Guanajuato, Jalisco, Aguascalientes, Zacatecas, Coahuila, Durango, and Chihuahua. Other lines completed connections with the Pacific coast as well as with several large coal fields near Ciudad Porfirio Díaz which provided the new network with its needed fuel. ${ }^{29}$

Lines from the United States met the Mexican railroads at the border and penetrated deeply into Mexico proper. The Southern Pacific Railroad of California built a line down the Pacific Coast of Mexico beyond the city of Mazatlan. The same company had reached eastward from California in 1881 through New Mexico and Arizona to reach El Paso, Texas, with its line. The Atchison, Topeka and Santa Fe company stretched from Kansas to California with border connections at El Paso. The Galveston, Houston and San Antonio Railroad later made connections with Eagle Pass, Texas. By 1890 , with the addition of other lines and several mergers, all of the forty-eight 
contiguous states of the United States were connected with the Mexican rail system. (See maps $1-3$.) ${ }^{30}$

Railway development was of paramount importance to northern migration. Railroad construction drew numerous workers from central plateau states. Labor recruiters, or enganchadores, actively sought workers there for the completion of the rail system. Many labor agencies, operating primarily from Mexico City, sent recruiters into the countryside looking for braceros. As a result of the inducements offered, "along the whole length of the railway lines which traversed the country gathered laborers, peons who had escaped the yoke of our great haciendas." Mr. Eber Byam, for example, worked in Mexico as a foreman for a track construction firm from 1895 to 1907 . During those twelve years he constantly traveled through the heavily populated central area and induced hundreds of villagers and migratory workers to leave their ancestral areas to go to work for his company. Labor agents, however, did not penetrate all areas of the region. News of higher wages available for construction work spread by word of mouth to thousands of unskilled peones, who learned they could earn four times their agricultural wage of $\$ .12-.15$ a day. Because of better medical care and schooling for their children, they were also assured of a better standard of living in the north. Employers were forced to provide their workers with fairly decent living conditions because of the relative shortages of braceros in the sparsely settled northern tier of states. If there were bad harvests or temporary unemployment, workers could always cross the border into the United States and earn supplemental money to tide them over the crises. ${ }^{31}$

This first wave of the "March to the North" was the forerunner of a massive exodus out of the south. The new rail system made possible the rapid development of many industries in northern Mexico as well as the creation of an agricultural export industry and a mining industry. The magnitude of the boom is typified by the experience of the city of Torreón, Coahuila. In 1882 the site of the future city was only a small village of 200 people. Its transformation began in 1883 and 1884 when the Mexican Central and the Mexican International Railroad chose Torreon as a train junction. This connected the city with Durango in the west and Saltillo, Monterrey, and Ciudad Porfirio Díaz to the east and northeast. By 1895, Torreón had a population of about 5,000 people; by 1910 , in excess of 34,000 . Industry developed to serve the new inhabitants: by 1895 the city boasted a soap factory, a textile mill, a brewery, and an ice plant. The surrounding hinterland developed a large cotton growing industry as well as other agricultural products to feed the city's inhabitants and to provide export crops for the United States. Labor for all these activities flowed from the central plateau region. Several hacienda owners there complained that almost their entire work force had gone to the La Laguna area around Torreón. ${ }^{32}$ 


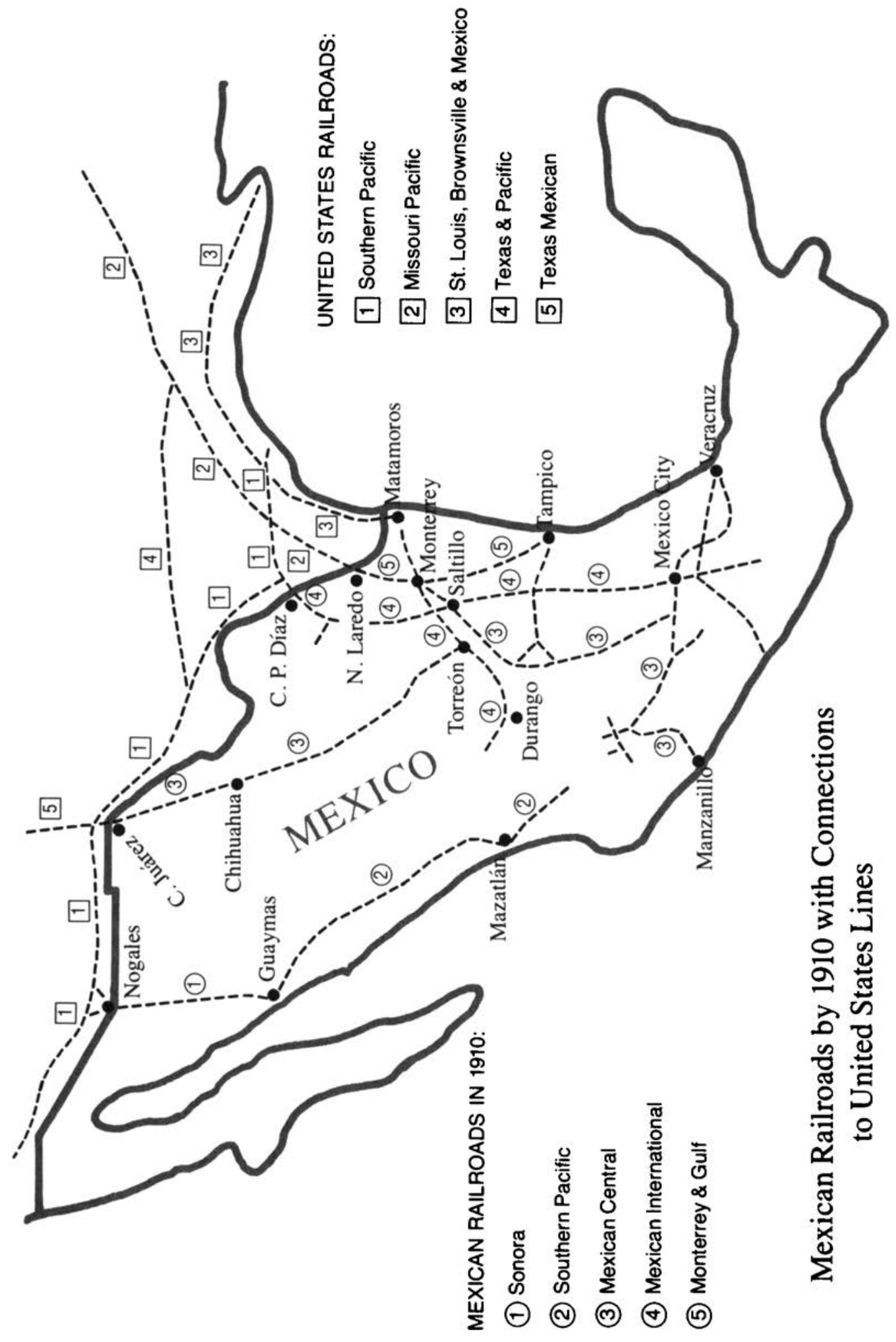




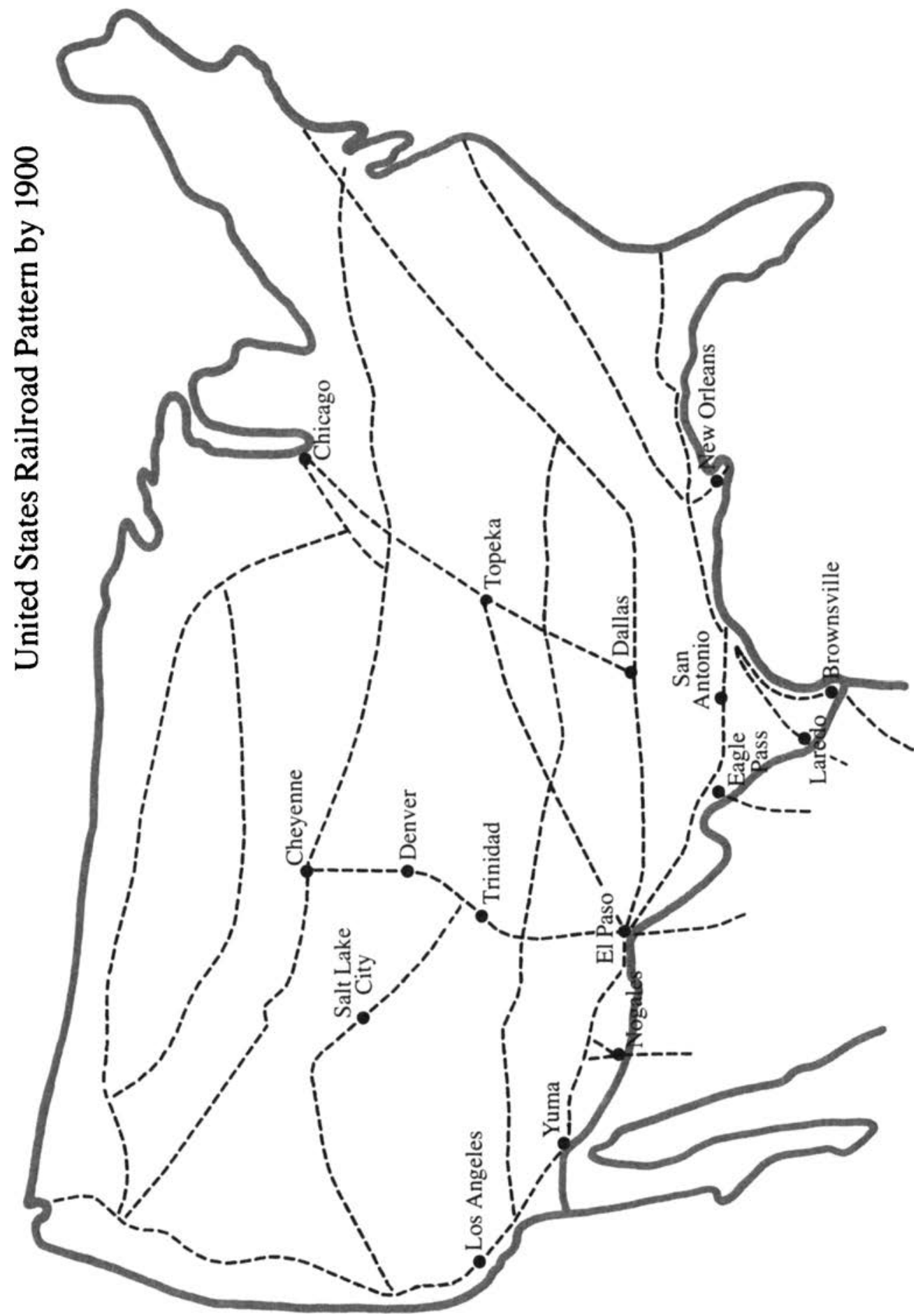


A mining boom in northern Mexico was also directly related to railway expansion. The Mexican International operated extensive coal fields around Ciudad Porfirio Díaz, worked by large numbers of campesinos brought from the south. Other extractive industries, such as the Cananea copper mines in the state of Sonora, only fifty miles from the Arizona border, also expanded rapidly. The newer and cheaper rail transportation made possible the export of metals as well as the development of smelters like those in Monterrey, Nuevo León. The northern drift of labor to work in mining is clear from the following statistics: in 1877,46 percent of all unskilled mine labor worked in the central plateau region, but by 1910 that area accounted for only 41 percent of the mining force. ${ }^{33}$

Wage differences paid to laborers in northern and central Mexico were another important factor in inducing migration. A peon in the central states rarely received a wage of as much as $\$ .15$ a day. Yet the same man could go north and earn $\$ .50$ a day working in railroad construction. Once this job was completed, he could earn the same wage or more in a variety of jobs calling for unskilled labor. Miners in the central area usually earned about $\$ .25$ a day, but could make up to $\$ .75$ for the same work in northern mines. This differential, especially for the unskilled peon and campesino, was a decisive influence in the northward drift of population. ${ }^{34}$

Immigration to the United States during this period could not have taken place without the development of northern Mexico. The area served as a funnel for braceros who left their native land. If the area had not been connected by rail to the more populous areas of Mexico, there would have been no outlet for dissaffected inhabitants of the core region. In the latter area rapid changes forced hundreds of thousands of people into the migratory labor stream. Rapid increases brought the population to a level where it outpaced the area's available resources of food supplies and economic activities. All of these pressures worsened the effects of the Díaz government's policy of destroying the ejido system in order to encourage white European immigration. Although this end was never realized, the government's initiatives did provide for the accelerated growth of the hacienda and the consequent harsh exploitation of displaced braceros so as to move Mexico toward her goal of a modern export economy. Economic liberalism had brought about conditions of restless turbulence for the majority of the country's citizens. This dissatisfaction had as one of its effects emigration to the United States. 


\section{Emigration, 1897 to 1910 : The Establishment of Patterns}

Large numbers of Mexicans crossed the border beginning around the turn of the century because of strong economic inducements in the southwestern United States. The development of mining and agriculture in particular required a large work force of unskilled and semiskilled laborers. The sparsley settled Southwest of the early 1900s did not offer to employers enough people to draw upon for this purpose; workers from Asia were rejected as a solution to these shortages. Employers therefore turned to Mexico as an alternative source. This solution to the labor shortage was acceptable to employers and the indigenous population at large who perceived the bracero as a "safe" immigrant who presented no danger to the Anglo-Saxon way of life. The government of the United States, in view of manpower shortages which would not allow internal development to proceed apace, went along with this regional special interest group and allowed immigration to take place largely unhindered by legal considerations. The number of Mexicans entering the Southwest grew rapidly, thereby providing the much-sought avenue of escape for Mexico's peon and campesino classes. Díaz's government remained preoccupied with internal economic development through the infusion of large numbers of European settlers. Only after the recession of 1907 had made clear the growing scope of emigration and the regime's political foes had seized on the issue as a point of criticism did Mexican officials attempt to initiate a program to dissuade would-be emigrants from leaving their native land and to protect those already across the border. The very eve of the Revolution of 1910, however, proved too late for the implementation of a coherent plan to deal with the problem. There was no effective impediment to Mexican emigration. 
Development was most dramatic in the extractive industries. Mining shifted away from the search and development of precious metals to the large-scale exploitation of deposits of copper and coal, especially in the states of New Mexico, Arizona, Oklahoma, and Colorado. New technology such as the steam shovel, dynamite, and more accurate instruments for surveying made possible the extraction of enormous quantities of ore on a profitable basis. Metals were then shipped from smelters to eastern industrial areas. Copper mining grew most dramatically: the number of mines went from 3 in 1869 to 180 in the year $1909 .{ }^{1}$

The expansion of agriculture was even more significant as it created a need for veritable armies of workers. Acreage planted to sugar beets increased more rapidly than any other crop after 1900 . The production of sugar from this crop to meet the domestic demand had been minimal until the Tariff Act of 1890 which mandated a cash bounty. By 1909 production exceeded $4,249,000$ short tons and was valued at over $\$ 23,000,000$. This new industry was centered in the Rocky Mountain and western Nebraska regions, both of which accounted for over 50 percent of all sugar beet production. Farmers in Ohio, Michigan, and California also began to grow this crop. Total land planted to sugar beets went from 110,170 acres in 1899 to 364,093 acres in 1909. All irrigated acreage, located primarily in the Southwest and devoted to other labor-intensive crops such as cotton, grapes, melons, lettuce, and other vegetables, almost doubled from 1899 to 1909 to slightly less than $14,000,000$ acres. Close to the border, citrus and cotton cultivation in California, New Mexico, Arizona, and the lower Rio Grande Valley of Texas flourished because of the new railroads and desert irrigation projects encouraged by the federal Newlands Act of 1902. Acreage reclaimed from the Imperial Valley desert, for example, totaled about 250,000 acres from 1900 to $1909 .{ }^{2}$

Farming areas in the Southwest were distinct exceptions to the typical pattern in other parts of the United States. Outside of the border area the majority of farms were operated by an owner and his family or by a small force of hired employees who often lived year-round on the property. This pattern was not, on the whole, found in the Southwest. Beginning during the periods of Spanish and Mexican sovereignty over the area, grants of land from crown or republican governments had frequently conveyed huge plots to private parties. In the arid climate a block of thousands of acres of land was needed if stockmen were to have a chance at economic survival. With the advent of irrigation projects many of these same properties, and others conveyed subsequent to 1848 , were converted to intensive agricultural use. The sheer size of the new farmlands obviated the possibility of a resident labor force. In any event, the sparsely settled Southwest did not have on hand a sufficient number of native laborers to perform farm tasks on a seasonal basis. Large numbers of workers, drawn from outside the local area, were needed. The most extreme instance of this patterm occurred in California. There, by 
the year 1900, farming operations of over 1,000 acres accounted for more than 60 percent of all agricultural acreage. ${ }^{3}$

Climate also stimulated the use of migratory labor by permitting the year-round production of crops. By 1900 growers in the Southwest raised specialized foods for a particular geographic market in the eastern or midwestern parts of the country. In this way, premium prices could be had for the product. In California, for example, lettuce was shipped from Salinas in the northern part of the state from March to December and from the Imperial Valley in southern California from December to March. Migrant lettuce workers had to follow the crops in order to obtain steady employment, and landowners could be assured of a work force acquainted with local crops through previous experience. The essential key to these operations was the presence of a migratory labor stream. The large-scale, intensive, and diverse nature of agricultural production required armies of men, women, and children to complete the growing season successfully. Workers had to move about the southwestern region in a timely fashion to meet the needs of growers, and they had to be willing to work for a low wage. ${ }^{4}$

Asian sources of cheap migratory labor were cut off just as agricultural expansion reached a stage of sustained growth after the turn of the century. Growers in California had relied extensively on Asiatic labor for land clearing and cultivation beginning in the $1860 \mathrm{~s}$. By 1882, 132,300 Chinese lived on the Pacific Coast, employed in mining, agriculture, and various urban enterprises. Public resistance to this group developed quickly, however. The recession of 1871 threw thousands of native workers out of their jobs, and trade unions began a campaign to halt further Chinese immigration in order to lessen competition for available jobs. Moreover, a strong popular revulsion developed against this group of Asians because of their very different race and culture. Not only were the Chinese denigrated as inferior individuals, but their native culture was portrayed as a danger to the United States. Bayard Taylor, a journalist from Philadelphia, expressed this sentiment in 1855 when he wrote, "their touch is pollution, and ... justice to our own race demands that they not be allowed to settle on our soil." These nationwide anti-Chinese attitudes brought about the federal Chinese Exclusion Act of 1882 which caused immigration from China to taper off immediately to an insignificant trickle. Growers and other employers sought Japanese as a source of labor, but, again, were frustrated in their attempts to secure large numbers of lowpaid workers. The Japanese proved to be highly competitive and unwilling to remain wage laborers for any period of time. Furthermore, they inherited the prejudices which had plagued the Chinese, and soon there were cries of yet another "Yellow Peril." The outcome of this situation was the Gentlemen's Agreement of 1907 whereby the Japanese government agreed to deny passports to its citizens who wished to emigrate to the United States. ${ }^{5}$

American nativism was the intellectual and emotional current most re- 
sponsible for the hue and cry raised against Asian immigration. The three major components of nativism, race, religion, and radicalism, provided a prism of fear through which local citizens viewed the infusion of large numbers of Chinese and Japanese workers. John Higham, author of the standard study of this phenomenon, defines nativism as "intense opposition to an internal minority on the ground of its foreign (i.e., 'un-American') connections.... While drawing on much broader cultural antipathies and ethnocentric judgements, [it] translates into a zeal to destroy the enemies of a distinctively American way of life." At the heart of nativism are the twin assumptions that some foreign groups may ultimately destroy the United States and its culture, that homogeneity is an ideal which must be attained if the status quo is to be preserved. The intensity and popularity of nativism ebbed and flowed, but always existed during the period under discussion here and were intimately intertwined with the question of Mexican immigration. ${ }^{6}$

American nativists at the turn of the century viewed Mexican immigration as a comparatively benign danger to the United States. The social distance between white culture in the Southwest and brown civilization in Mexico was short compared to the yawning chasm between the worlds of white and yellow. Porfirio Díaz ruled in Mexico with a coterie of individuals who were friendly to the United States and its citizens who wished to invest money in the country. Industrialization was proceeding rapidly and the modernization of agriculture was bringing prosperity and the chance for further investments in rural areas. Nor was the Mexican an unfamiliar person in the Southwest. The area had been populated by people of Mexican descent since the late $1500 \mathrm{~s}$. All citizens of the United States who came to the area after 1848 had been confronted with the presence of the Mexican and his language, architecture, religion, and food. Moreover, by the late 1800 s and well into the twentieth century there appeared in the cultural matrix of the Anglo-Saxon world a romanticized, acceptable view of the "Spanish" Southwest and its inhabitants. Literary works portrayed the area as an idyllic, pastoral refuge from the hurried, sooty, money-grubbing industrialism of the eastern United States. Thus, the stern race consciousness of whites, so much in evidence when it came to Asian immigrants, mellowed to a degree and showed more tolerance toward the Mexican. ${ }^{7}$

To be sure, the white community's consensus at this time labeled the Mexican as an inferior being. Anthropologists of the late nineteenth century viewed the Mexican people as a regressive group because of their biological antecedents. The Indian genetic pool, despite more than three centuries of intermixture with Spaniards and Europeans, had brought about a race which was perceived as lacking self-reliance, foresight, a sense of abstraction and calculation, and stability of character. In short, the Mexican, particularly from the uneducated, lower classes, was innately precluded from attaining 
the industrial and political evolution which whites in the United States had attained. A large body of popular opinion also regarded Mexicans as inferior to whites. These beliefs had been widespread since the time of the war between the two countries from 1846 to 1848 . Invading troops had eagerly anticipated a bold, swift victory against a nation said to be composed of Indians, half-breeds, and blacks, "mere slaves" and "degenerate Spaniards." 8

Mexican immigration was perceived as distinct from that of other groups, even in the eyes of the most rabid race determinists. Braceros were alleged to have a "homing pigeon" instinct. They did not have to cross vast oceans to secure employment in the United States, and were never more than a short train ride away from their native land. The general presumption was that members of this group worked in local fields or mines for a season or two and then returned to Mexico to spend the money they had earned for improvements on their family property somewhere south of the border. The Mexican was a "safe" worker to bring into the bosom of the American nation for short periods of time. He would not settle permanently near his place of employment, would cause no threat to the status quo, and would create no social problem as had the Chinese and Japanese. ${ }^{9}$

Other racially determined characteristics distinguished Porfirian immigrants. Ironically, the Mexicans' much-touted lack of ambition also favored their acceptance by employers and the population at large. They would not purchase land and compete for farm markets dominated by whites. They were tractable, obedient, and quick to learn under proper supervision. Furthermore, the climate of their native land and their genetic makeup were said to suit them ideally for arduous work under the hot southwestern sun. The bracero was also usually willing to work for a low wage. What had proven to be a miserly wage for Europeans, Asians, and native laborers was an adequate income for the peon or campesino from rural Mexico. The Mexican was also often the only one willing to perform tasks disdained by others because the wage structure and working conditions compared so favorably with those found in his native land. The Pacific Fruit Grower, a news organ of western agriculture, best summed up these views in 1907 when it called for the importation of large numbers of Mexicans who were "plentiful, generally peaceable, and ... satisfied with very low social conditions." 10

Wages available to Mexican workers provided, by themselves, a strong impetus to continuing emigration. Rural wages in Mexico hovered around $\$ .12$ a day for those working on the great haciendas. Those unwilling or unable to work for that wage had little else available to them in their native land. In the United States, on the other hand, employers paid markedly higher wages to their unskilled workers. Grubbers who cleared land in south Texas earned $\$ .50$ a day; a miner could earn well over $\$ 2.00$ daily; railroad workers were usually paid $\$ 1.00$ to $\$ 2.00$ a day. Table 2.1 brings the wage differential into focus. 


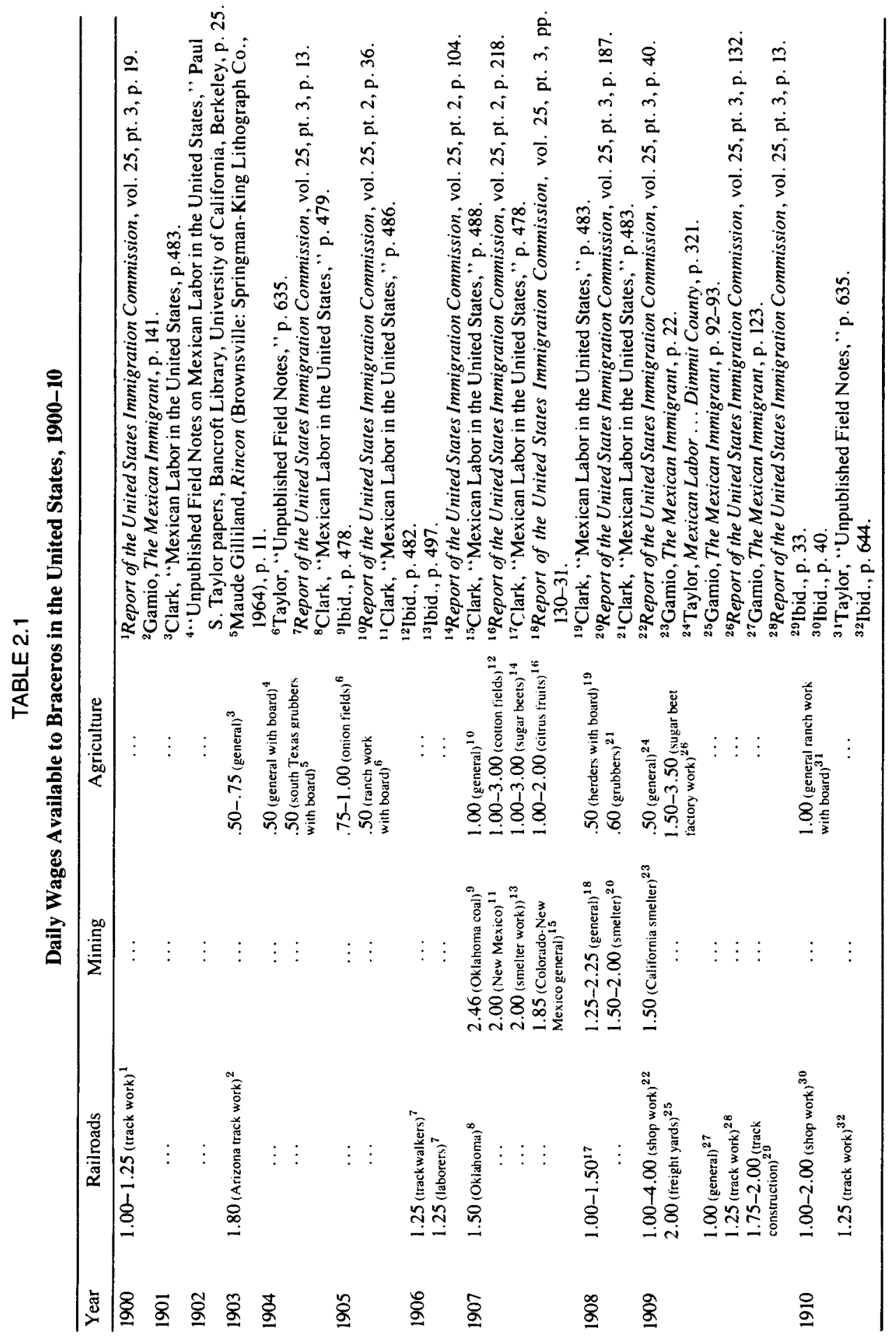


Large numbers of Mexicans came to the United States to work in agricultural areas. California growers began to import workers in large numbers in 1907. Earlier in Texas, Mexicans had been employed by the thousands as grubbers to clear the land of brush and cactus so that it could be leveled and irrigated. Once this was done and the land was planted to crops, the same workers, and many more after them, stayed on to continue working. There were many farming areas where braceros never formed more than a tiny percentage of the work force. This was particularly true in the midwestern region, where well before the start of World War I extensive mechanization through the use of gas engine harvesters and seeders had eliminated the need for large numbers of farm workers. This was particularly true for crops such as corn, wheat, hay, and other forage crops which were produced in such abundance in the area. The crops that were grown and harvested partially or exclusively by hand came to form the major employment areas for agricultural braceros through the 1920s and afterward. Sugar beets, for example, continued to be produced with almost no mechanical aids; as late as 1942 cotton harvesting still required 4,000,000 pickers; most vegetables and fruits could be handled only partially by machinery. ${ }^{11}$

The key element in unmechanized agricultural production during this period was stoop labor. Human muscle with the help of simple tools performed almost all tasks from the planting of seeds in spring to harvesting the crop at the end of the growing season. Sugar beet cultivation was typical of this type of labor-intensive activity. Workers first had to prepare the soil for planting by breaking up dirt clods and removing stones and weeds. They then planted and covered seeds in rows that stretched for mile after mile on all farms where this crop was grown. As soon as the new shoots were above the ground, they had to be thinned, leaving only the strongest. Thinning was done by the workers on their hands and knees. As the summer season progressed the crop needed daily attention such as constant weeding and loosening of the earth, and irrigation. At the end of the harvest season the beets were pulled from the ground and their tops cut off. The work was extremely fatiguing and poorly paid when compared with the money available in nonagricultural pursuits. Most United States citizens refused to engage in this type of work, or, at best, would do it only as a temporary expedient. Growers therefore brought in thousands of Mexican migrants to work the beet fields and other crops. ${ }^{12}$

Braceros came to form a large part of the sugar beet work force well before 1910. The labor pool, easily tapped by labor recruiters at border cities such as El Paso and moved northward and westward by railroads such as the Southern Pacific and the Santa Fe, provided growers with thousands of workers. The experience in the South Platte Valley of Colorado was typical. As early as 1906 nine processing plants for beets had been built. The first Mexican workers were brought in in 1903; by 1909 there were more than 2,600 of them and they constituted over 40 percent of the total sugar beet work force. 
In California, similar rapid increases took place in the growth of the Mexican migrant community. The Dillingham Commission, in its study of immigrants, reported 1,000 Mexicans working in California beet fields out of a total of 6,000 to 7,000 men and women..$^{13}$

Closer to the border Mexican migrants comprised larger percentages of the work force. The cotton industry in the Imperial Valley of California, for example, could not have developed were it not for the bracero labor force. As one early grower stated: "the picking of cotton is held to be a drawback in the valley [because of the lack of native laborers for stoop labor], but this is not true. We mean to get Mexicans for the work and get all we need... "' This is precisely what happened: by 1910 the local newspaper, the Press, was running advertisements of local labor agencies for "as many [Mexican] pickers as may be wanted," and braceros made up almost 100 percent of the field hands in the area. Similarly, the development of citrus and truck gardening industries in southern California, in the lower Rio Grande Valley, and in the lower Colorado River area rapidly became dependent on Mexican migrant labor. This labor, combined with the presence of refrigerated railroad cars, allowed shipment to midwestern and eastern markets of items such as tomatoes, citrus fruits, onions, cabbage, spinach, carrots, cucumbers, and watermelons. As early as 1900 one produce company shipped over 40,000 carloads annually of farm products to eastern markets, and companies in all of California shipped eastward over $\$ 159,000,000$ worth of produce by 1909.14

Texas's lower Rio Grande Valley is another striking example of the link between agricultural prosperity and Mexican workers. With the completion of the St. Louis, Brownsville and Mexico Railroad in June 1904, the area began a sustained period of economic development. The new transportation facility tapped into the supply of migrant labor through its connection with the Mexican rail system at Matamoros, Tamaulipas. To the north, the new railroad linked with lines to more populous regions of the United States. Within a few years dozens of cities sprang up to service the newly established farm areas. Kingsville, Texas, for example, did not exist in 1904, but by 1914 it was a thriving town of 3,000 people with railroad offices, machine shops, and many commercial establishments. Many other urban areas in the Valley experienced a similar pattern of development..$^{15}$

Nueces County was a prime example of agricultural growth coupled with the development of auxiliary enterprises in southern Texas. Before 1904, the county, including the city of Corpus Christi, exported sheep and cattle, using Mexican shepherds and cowboys to raise and tend the animals. The economic structure of the county changed radically after 1904. New farms sprang up to produce fruits, vegetables, cotton, and pecans as these crops had become more profitable than livestock raising. Cotton, to give one example, jumped from 498 bales ginned in 1899 to 8,566 bales by 1910 ; produce shipments totaled 125 railroad carloads in 1909 and had been higher earlier (321 carloads 
in 1907) owing to more favorable weather conditions. The economic change was reflected in the county's population which rose from 10,439 in 1900 to 21,955 in 1910. Paul S. Taylor, in his extensive history of the county, found that it was Mexican migrant labor which provided the bulk of the labor force needed for the changeover. Mexicans cleared the land of brush and cactus and helped to level it. Later they were instrumental in planting, tending, and harvesting the new crops. Almost 60 percent of the migrants came from the central plateau states of Mexico and had increased the number of Mexicans in the area from 1,983 in 1900 to 2,828 in $1910 .{ }^{16}$

Well before 1910 agriculture in the southwestern and parts of the western United States had become heavily dependent on Mexican migratory labor. By word of mouth or through letters from relatives, peones in central Mexico quickly learned of the relatively high wages which were available. Victor S. Clark, the first to study the causes of Mexican emigration, wrote in 1908 that railroads regularly carried thousands of villagers and former hacienda workers a thousand miles from their central plateau homes to the border. Once they were at the border employers had little difficulty in attracting them to the United States with the promise of high wages. Spring planting in the United States had caused a new phenomenon in border cities in northern Mexico well before the start of the Revolution of 1910: a steady stream of emigrants who crossed the border to provide the human muscle so necessary to unmechanized agriculture. In one city, Ciudad Juárez, Chihuahua, just across the border from the great rail center of El Paso, Mexicans left their native land at the rate of 100 to 150 a day during the spring exodus. ${ }^{17}$

Intensive coal and copper mining operations in the Southwest also drew braceros over the border. Mexicans took jobs in mines that others refused to do. They chopped wood for timber, did general cleanup work, and extracted ore with pick and shovel. The coal mining district of southern Colorado, near the towns of Trinidad and Pueblo, was an area of heavy Mexican settlement. Over 10,222 Mexican miners and their families lived in the area as early as 1905 , and comprised more than 10 percent of the total work force of one of the largest companies there. Elsewhere coal companies providing fuel for the railroads employed many Mexicans. This was especially true in the mines near Gallup, New Mexico, and in southern Texas. Those operations, a scant forty or fifty miles from the Cananea copper mines in Mexico, drew many workers from the latter area. ${ }^{18}$

It was the railroads more than any other single factor that pulled Mexican workers over the border and spread them over the entire Southwest and beyond as a mobile, cheap labor force available for all types of unskilled work. Railroads also determined the early settlement pattern of Mexican communities. Braceros were initially brought to the United States and used extensively to lay tracks and construct roadbeds; many then stayed on to fill 
track maintenance jobs. Administrators quickly came to favor Mexican workers. The campesinos and peones learned fast, worked hard, long hours, and they were efficient in their tasks. Perhaps more importantly from the viewpoint of his employer, the Mexican worked for a lower wage than members of other groups: a dollar or more per day for common labor work offered a powerful inducement to the bracero. In one village, Arandas, Jalisco, the first worker who brought back word of wages available for railway work in the United States initiated a steady stream of fellow emigrants who sought similar wages. Mexican laborers comprised over 10 percent of the workshop crews on southwestern railroads by 1909 and made up more than one-half of track crew personnel on most of the same companies' lines. The fact that Los Angeles, California, one of the main rail centers on the Pacific coast, had a Mexican community of about 15,000 in 1908, was in large part because of the employment of braceros by railroad companies. Other rail centers such as San Antonio and El Paso in Texas, and Kansas City, Kansas, also attracted thousands of Mexican workers. Railway camps provided braceros not only for immediate employers but also for a large, surrounding hinterland. Since there was often a large number of unneeded workers in these railway centers, they served as a way station for migratory laborers who could go in any direction to follow crops or other seasonal work. ${ }^{19}$

Railroads infiuenced the pattern of settlement in other ways. The railroad companies frequently served as temporary, intermediate employers. Coal mines in Oklahoma hired scores of Mexican track construction workers once rail lines in the state had been completed. Indeed, many who worked on the tracks had earlier deserted their original employer and had gone to the coal mines; a similar occurance helps account for the more than 10,000 braceros around Trinidad, Colorado. Pay for work in the mines ranged as high as $\$ 2.46$ a day compared with the $\$ 1.00$ a day average wage for railroad work. Precisely because of this pay differential, mines were the constant recipients of former rail workers in search of higher pay. Partly because of this drift of labor, Mexicans made up almost 100 percent of the personnel in copper and smelting operations near the border by 1910 . Railroad companies also encouraged the agricultural employment of Mexican migrants. In many areas served by the companies there was not sufficient labor to tend and harvest crops. In order to promote production in areas along their rights of way and thus to increase their carrying trade, rail corporations frequently allowed farmers to borrow temporarily or to hire permanently their Mexican workers. After all, they would have no problem replacing the lost workers with new ones from a nearby city or from below the border. ${ }^{20}$

An extensive system of labor recruitment drew braceros across the border in order to provide the manpower needed in the Southwest. Many companies opened contracting offices in border towns in the United States and 
used Mexican recruiters to reach deep into Mexico. This practice was carried on despite the federal Immigration Act of 1885 which forbade alien immigration induced by promises of employment. Later amendments to this law attempted to stiffen this prohibition by offering rewards to informers and empowering the President to refuse admission to those people whose entrance into the United States would be detrimental to the intent of the legislation. Apparently this contract labor law was designed only for the entry of aliens through seaports. There immigration officials could easily enforce its provisions as immigrants disembarked from their ships. The border with Mexico by its very nature frustrated the intent of the federal legislation. It was nearly 2,000 miles long, and a group of mounted officers, never in excess of seventy-five men before 1910, had the responsibility for policing the border to prevent illegal walk-in entries. Their task was a hopeless one. Over 22,000 railroad cars carrying 70,000 passengers entered the United States from Mexico each year well before 1900 . Outside of a handful of towns that served as official ports of entry the border consisted of an imaginary line running through vast, underpopulated desert regions. According to one thirty-year veteran of law enforcement along the border, the international line of demarcation remained largely unpoliced and unregulated before 1910 and for many years thereafter. ${ }^{21}$

Recruiters from the United States worked openly with their counterparts in Mexico. The Mexican enganchador drew upon displaced campesinos and peones who milled around Mexican border towns after their flight from rural villages or haciendas. It seemed dangerous for the recruiter to seek laborers in rural areas because of the hostility of the hacienda employer and the rural police. Many of the recruiters in Mexico were Mexican Americans. Because of their unobtrusiveness of skin coloring and language they could go about their work in the towns along the border with little fear of being noticed. Their promises and descriptions of conditions in the United States greatly facilitated the recruitment of large numbers of Mexicans. Once a laborer was "hooked" (enganchado) by a recruiter there were several ways he could get to the border and across. Some went in a gang headed by a crew leader. Once in the United States the recruiter from Mexico handed the group over to his partner in the United States and received his commission of a few dollars per head. With the workers in hand and over the border the second agent turned them over to their employer and received his fee for the transaction. The cost of railroad tickets was later deducted from the pay of most of the workers brought into the country in this manner. Braceros often paid their own fares to the border after having raised the money through loans from friends of relatives or through the sale of personal property. The newcomers were eagerly received by labor agents. ${ }^{22}$

Agents in border towns were in turn connected with contractors in interior parts of the United States. Clark reported agencies as far from the border as Denver and Trinidad, Colorado. Closer to the border employment agencies 
acted as if they had never heard of the law of 1885. An agency in Corpus Christi openly advertised in 1909 for the services of all kinds of Mexican workers at reasonable rates. Most of the larger agencies were responsible for profiteering in the supply of food, shelter, and clothing along with various commissary provisions for contract workers. Clark wrote that "indeed, this is their main source of revenue ... to furnish labor ... in return for the privilege of keeping the commissary." He went on to describe the arrangement as a modified form of debt peonage:

The workingman buys at the commissary because he can get credit there, which is not given by other merchants; and the commissary can grant this credit because its arrangement with the employing corporation gives it the exclusive right to charge such debts against the pay roll. Laborers who pay cash are generally free to patronize other stores. Although the commissary debts are thus secured to some extent, prices are high, the reason given for this being that losses from bad debts are very heavy. ${ }^{23}$

Private employers near and far from the border also sent their own agents to recruit workers. The owner of an establishment or his foreman directly recruited Mexicans along the border or openly dealt with those whose jobs were the inducement of immigration. With the promise of good working conditions and high wages, it was not unusual for planters from Texas, Oklahoma, and Colorado to gather up at the border a party of one hundred or more men and their families and take them far inland to their farms. ${ }^{24}$

United States citizens and corporations who had business enterprises in Mexico were another important element in the development of the recruitment of workers. Many railroads in northern Mexico were owned by investors from the United States. These entrepreneurs frequently had interests in rail lines in the United States such as the Southern Pacific. A similar concentration of foreign ownership was evident in mining: by 1910 three-quarters of all active mines in Mexico had passed into the hands of American investors. In the state of Chihuahua alone, this investment totaled almost $\$ 100,000,000 .{ }^{25}$ The people with these rail and mining interests helped start the migratory process by bringing their trained work gangs over the border to work in their establishments. For example, thousands of miners went from Anaconda copper mines at Cananea, Sonora, in northern Mexico to work in Anaconda mines in southern Arizona. Naco, Arizona, just to give one example, had a Mexican mining community of over 2,000 adults in October 1908. Railroad companies' importation of braceros was even more marked. As early as 1900 Mexicans comprised from 70 to 90 percent of the track crews on all the principal southwestern lines. The Southern Pacific was importing two to three carloads of workers each week in 1906. In one eight-month period, July 1908 to February 1909, western railroad companies brought in 16,471 workers, many of them former employees of the companies' Mexican branches. ${ }^{26}$ 
This heavy, chronic outflow of population was the object of intense concern and criticism in Mexico. As early as 1901 opposition newspapers initiated a blistering attack on the Porfirian government's apparent lack of concern with emigration. El País, a Catholic daily published in Mexico City, remained in the forefront of this stream of attacks. The validity of capitalist modernization for Mexico was questioned in light of the emigration that it spawned. If economic development and growth were balanced and vigorous, sufficient employment and adequate wages would be available to braceros. It was a loss of national dignity and self-respect to have so many nationals forced abroad to earn their daily bread. What Mexico needed, an editorialist concluded in October 1907, was an end to the "silence of adulation" of Díaz and a thorough examination of the evils that beset the rural working classes. Provincial and expatriate newspapers also scrutinized emigration in the light of the much-touted progress claimed by governmental spokesmen. El Comercio, published in Hermosillo, Sonora, sarcastically noted that six demented Mexicans had been deported from Arizona and would soon be begging in local streets. Officials who had permitted this situation to develop were said to be "non-entities, pure non-entities." For them to say that Mexico enjoyed prosperity was an outright lie in the face of the lack of work which first forced the men abroad and then failed to provide for them once they had been deported. ${ }^{27}$

The press also freely criticized the lack of protection afforded braceros in the United States by their government. Workers were said to be humiliated by immigration authorities when they were examined at border entry points. Workers were then bought up by labor contractors like sides of beef and shipped to points far from the border and their native land. Often, they were subject to rampant discrimination and ill treatment at their places of employment because of their skin coloring and culture. False promises were made to them regarding wages and working conditions, and, once their seasonal work was no longer available, braceros were thrown on their own meager devices to get back home. The fault for this situation did not lie with the illiterate, defenseless expatriates; the blame rested solely with the uncaring attitudes of the Mexican consular service and the national government in Mexico City. ${ }^{28}$

Unexpectedly strong reactions also came from people who had allied themselves with the government and its policies of economic modernization. Hacienda owners in the central states of Jalisco, Guanajuato, Zacatecas, and Michoacán complained of the chronic shortages of labor brought about by peon flight to the United States. The landowners also wanted to know why the government was doing nothing to stop returning workers from spreading new ideas and inducing many of their former co-workers to flee their bondage. A new and better way of working and living was made known to the more adventurous hacienda employees, and money and luxury items brought back from the United States offered visible proof. Oscar J. Braniff, owner of 
several large haciendas and at times a confidant of Díaz, even suggested that the daily plethora of peones heading north was proof that the indigenous lower class was not indolent and refractory by nature. Perhaps many of the social ills of rural Mexico could be better explained by a re-examination of the prevalent attitudes and resulting policies of employers and officials. ${ }^{29}$

Many political enemies of the status quo also seized on the issue of emigration as a chink in the armor of Mexico's capitalist development. The Flores Magón brothers' Liberal party manifesto of July 1, 1906, excoriated the ill treatment and low wages of agricultural workers in Mexico, saying the rural proletariat class had been reduced to the status of a "decayed beast." The emigration that resulted from this situation made it obligatory that the Mexican government immediatly repatriate all braceros in the United States and give them land to work once they had returned. Francisco Madero also spoke of this issue in his campaign which was ultimately to topple Diaz from power in 1911. As he expressed his feelings in his La sucesión presidencial en 1910 , " The situation of the Mexican worker is so precarious that despite the humiliations suffered across the Rio Grande, thousands annually emigrate to the neighboring republic and, in truth, their luck there is better than in their native land. Mexico is the only country in the Americas where citizens emigrate to foreign lands. "30

In the face of this mounting criticism it is suprising that the Diaz administration took as long as it did to view emigration as a by-product of serious problems on the home front. Indeed, until the eve of the Revolution of 1910 the government warmly defended emigration as a necessary and natural manifestation of laissez-faire economics. The poor laboring classes were said to possess only their labor as their capital. Since the laws of supply and demand must operate unhindered by the government, it would be "unnatural" 'to interfere with emigration, a logical and necessary way for the poor to profit from their only resource. The higher salaries earned in the United States were a strong inducement to go there; to attempt to raise wages at home to offset emigration would also constitute undue interference with the free market economy. In any event, most workers were said to return to their homeland either because of their inability to adapt to the United States, or their natural desire not to stay abroad for an extended period of time. The government's only responsibility, in short, was to protect braceros who were inequitably treated in the United States and to try to induce employers to pay the costs of repatriation once the harvesting season was completed.$^{31}$

Even this limited role assumed by the Porfirian government was not fulfilled until after the spurt in emigration which resulted from the recession of 1907 . Beginning in 1897 consular reports from officials in the United States had been circulated to personnel of the Department of Migration and governors of selected central states. The information disseminated in this manner always related to adverse conditions faced by braceros in the United 
States. The item relayed was sent as information which might be of interest to local newspapers but was not intended specifically to dissuade workers from leaving their native locales. In this manner news of unemployment because of mine shutdowns, disasters resulting from fires and other natural causes, and discrimination against Mexicans were all reported. Apparently, these notices had little or no effect upon the stream of northbound laborers. ${ }^{32}$

Mexican consuls did at times aid braceros who sought assistance. One of the primary forms of help was the facilitation of repatriation for those who were unemployed and destitute. At the end of 1907, for example, several thousand railroad track laborers in California and Arizona lost their jobs because of the effects of the recession. Local consuls met with officials of the Southern Pacific Railroad and persuaded them to provide free transportation to the border city of Ciudad Juárez. After they had returned to Mexico the braceros received food and free rail passes to their homes in the interior. ${ }^{33}$

A combination of developments by the beginning of 1908 caused a new intensity and larger scope in the role played by consuls in the United States and brought about a heightened concern with the effects of labor expatriation on Mexico. The attitudes of casual concern and the hit-or-miss protection policy gave way to the start of a coordinated campaign to deal more effectively with the problem. The recession of 1907 played an important part in these new realizations. Many braceros in the United States had lost their jobs, and the consequent desperate plight of those who returned to Mexico had come into full public view. Not only was it evident that emigration involved many thousands of workers, but it was also plain that the Porfirian government could only respond to the situation as it developed and was not in a position to control events. Too, by 1908 criticism of this largely do-nothing policy was growing. Landowners complained of untilled lands and uncollected harvests because of the lack of workers, and political activists used immigration as part of the salvo of charges of mismanagement hurled at the government. Perhaps trying to fend off a potentially dangerous issue in the upcoming presidential elections of 1910, Díaz ordered his Secretaries of Foreign Relations, Ignacio Mariscal and Enrique C. Creel, to take steps to solve the problem.

Creel sought in vain to ascertain the number of emigrants in the United States from his consuls. The latter had not paid much attention to the local Mexican community and did not have the resources to carry out a census of Mexicans in their districts. Creel cabled his government's embassy in Washington, D.C., for a figure. As the census of 1900 was the only information the ambassador and his staff had, he remitted the figure of 103,000 Mexicans in the United States as of that last census date. In a parallel effort to discover the root causes of the loss of Mexican nationals, Creel attempted to find out from state officials and personnel of the Department of Migration stationed in border towns the reasons that were given by workers going north. The results from this effort were apparently not satisfactory, for in July 1910 
Creel formed a commission in his ministry which was to determine the causes of emigration and formulate a policy that could be used to keep nationals at home. The approach of revolutionary upheaval, however, prevented his even naming people to serve on the study group. ${ }^{34}$

Not all of Creel's efforts met with such minimal results. Workers in the Ministry of Foreign Relations gave to newspapers copies of all consular reports which referred to the drawbacks of life across the border. Editors were asked to give full publicity to this propaganda and to offer pointed advice to would-be emigrants to stay home where things were better for them. At face value the news stories painted a gruesome picture wherein workers were always lied to and maltreated by employers and government agents. The pro-government newspaper El Imparcial labeled as traitors those workers who were foolish enough to expose themselves to life in the United States. Agricultural production was indeed not what it should be, an editorial writer observed in early 1910 , because of the desertions of much-needed workers who flocked to the aid of the United States ${ }^{35}$ It is probable that this press campaign had no effect upon emigration. Those who left Mexico did so to flee the same people and institutions which now sought to keep them home through bluster. No move was afoot to raise wages or improve working conditions on the hacienda; no person in a position of power talked about the restitution of ejidal land taken away from rural villagers. There was simply no valid reason to place trust in the words and warnings of officialdom now.

Consuls in the United States did initiate an amplified policy of assistance to workers because of directives from the Secretaries. Practical considerations had forced the diplomats to abandon their earlier philosophical concern with the braceros' free exploitation of their natural capital. The consul in Phoenix, Arizona, Arturo Elias, accompanied four stranded, unemployed track workers to several company offices and assisted them in getting new jobs. In Bisbee, Arizona, the consul urged the equal treatment of his fellow countrymen by municipal authorities in the wake of a disastrous fire which deprived many local residents of their housing and access to city services. Other officials closely watched court cases where Mexicans were involved to insure their equal treatment under the state and federal civil rights laws of the United States. In most cases of this type of vigilance, copies of the consular reports were dutifully forwarded to newspapers, especially where the consuls had helped undo some harm to their clients. ${ }^{36}$

If the Porfirian government's policy was too late and too little to have an impact on emigration, the policy of the United States' government was more forceful in its effects. Policymakers in Washington accepted the arguments of southwestern growers and other employers as to the benign nature of the Mexican. The conclusions of the Dillingham commission, which generally reflected a moderately restrictionist viewpoint, evinced a pro-immigration stance when it came to the matter of the need for workers in the Southwest. Members of the commission believed that Mexico's economy was 
rapidly expanding and thus providing jobs for most people who sought employment; furthermore, the differential in wages available in the two countries was thought to be narrowing rapidly. Unlike the "new" immigrants from Asia and eastern and southern Europe, braceros were transients in the country only for a short period of time and always came in small groups. In short, the Mexican provided the booming southwestern economy with a "fairly acceptable supply of labor in a limited territory in which it is difficult to secure others." 37

The attitude of the Dillingham commission allowed the development of a local, regional veto over national immigration laws. Incoming Mexicans were exempted from the head of $\$ 2.00$ and $\$ 4.00$ levied, respectively, by the Immigration Acts of 1903 and 1907. These exceptions were "in the nature of a favor," and "great inconvenience and discomfort" to the free intercourse and intermingling of people living along the border would result if the levies were to be applied. Private corporations such as the Southern Pacific Railroad wholeheartedly urged these exceptions to the law so as to preclude obstacles to their transnational passenger service and to ensure an ample supply of incoming workers from Mexico. ${ }^{38}$ Applicable national laws, principally those of 1885, 1903, and 1907 which forbade the entry of prior contract laborers, the diseased, the insane, and certain criminal classes, were enforced little if at all on the Mexican border because of administrative procedures which further catered to the special interests of southwestern employers. Until 1908 the United States Bureau of Immigration did not even bother to count the number of incoming Mexicans except for the small number who signalled their intention to settle permanently in the country. Examination of the northward flow of braceros was limited to a few specified ports of entry because of the prohibitive costs of policing the entire land border; at times, no inspectors of any kind were in the area because of shortages of funds. To what use were existing personnel put? The Annual Reports of the Commissioner General of Immigration make it abundantly clear that the exclusion and deportation of Chinese and Japanese who crossed the border illegally through Mexico were the primary concern of officials in the area. ${ }^{39}$

With no effective bars to it, Mexican immigration grew rapidly in the first decade of the twentieth century. The open-door policy of each of the governments involved makes it difficult, however, to assess the number of braceros who worked in the United States and returned to Mexico or who stayed permanently in the United States. Neither country kept statistics of the labor movement until 1908, and the underpopulated, desert nature of the border region meant that immigration was in large part "invisible." It is possible that more than 500,00 border crossings took place from 1900 to 1910 . This estimate seems substantiated by the few public announcements of the time. In 1910 the Mexican Secretary of Development thought that over 50,000 of his countrymen left yearly for the United States. Victor S. Clark, 
after his extensive tour of the border area in 1908 , believed that the number of emigrants totaled 60,000 a year; the United States Commissioner General of Immigration estimated the number at $50,000 .{ }^{40}$ Other extant sources provide little satisfaction in arriving at a determination of the scope of immigration. From 1900 to 1907 officials counted less than 6,000 Mexicans as crossing the border with the intent to settle permanently. From 1908 through 1910 this category totaled almost 40,000 people. Several sources of data do suggest that the generally accepted figure of about 50,000 a year may be too low an estimate. Several examples will suffice here: the Dillingham commission found that in the eight months from July 1908 to February 1909 five labor recruiting agencies in El Paso supplied five railroad companies, with 16,471 workers; in a few weeks during the summer of 1907, long after the peak period of spring planting, over 7,000 braceros left their country through Ciudad Juárez. ${ }^{41}$

The federal census of 1910 does not provide complete information either but is probably the best indication of the "tip of the iceberg" of Mexican immigration. This enumeration was plagued by problems, particularly in the sparsely settled sections of the West and Southwest. Time and funding for a thorough survey were lacking; enumerators were paid on a per diem basis and frequently failed to carry out a comprehensive survey in the districts for which they were responsible. In addition, distrust and suspicion were common responses to the questions they asked. This situation west of the Mississippi resulted in a general undercounting of the people in the area. To further compound the problem, the total lack of Spanish-speaking enumerators probably accounted for an even higher incidence of error in counting members of the Mexican community. Moreover, Mexicans were not classified as an identifiable group. Instead, they were listed as "white" because local usage in the West defined an Indian as a descendant of hunting and nomadic tribes. ${ }^{42}$ The general problems of the Bureau of the Census in the West, and the special problems encountered in counting and classifying braceros, surely did result in undercounting. It would not be unreasonable to assume that the following figures represent only 90 percent of the braceros who were in the United States in 1910.

Census figures alone show a striking increase in the number of Mexicans from 1900 to 1910 . The count in the former year reported 103,393 citizens of Mexico; by 1910 this group had increased to 219,802 , a gain of 116,409 . In addition to this increment must be added the 107,866 people listed in the census of 1910 as children of Mexicans who were born in the United States. These young people were citizens of their parents' place of residence, but they were also members of a distinctive cultural and racial enclave which was viewed as foreign by the vast majority of other United States citizens. Their identity, as defined by both their parent group and the wider community, was therefore Mexican and they will be considered as such in this study. The 
census of 1910 also lists 54,334 people as children of mixed parentage, that is, having a Mexican mother or father. It is now impossible to determine what percentage of this latter group would be culturally and racially defined as Mexican because of the unavailability of more detailed census records. Therefore, the first two categories, braceros together with their children born in the United States, represent the best extant source reflecting the growth of the Mexican community for the first ten years of this century. This group totaled 327,668 people, an increase in excess of 300 percent when compared with the total of 103,393 in 1900 . If we assume a modest correction factor of 10 percent, we may add 32,767 people to the reported total for a sum of 360,435 . An estimate made by personnel in the United States Bureau of the census in 1930 supports this revised figure. When the definition of "Mexican" used in the count of 1930 was read back to the census of 1910 , including all persons born in Mexico who were not white, black, or Oriental, and all persons whose parents had been born in Mexico, the estimate for 1910 was 367,510 . This latter figure nearly agrees with the 10 percent correction factor discussed above. The exact number of immigrants probably lies somewhere in between the two estimates. ${ }^{43}$

This large number of Mexicans who entered the United States helped form some patterns of emigration and employment which were to last until the Great Depression. Migration mounted in the spring as braceros flocked northward to seek employment in the fields of the Southwest. This pattern, in addition to the less fluctuating labor flow to mining and railroad enterprises, meant that the size of the bracero community peaked in the time from late February to October. The types of work available were also developed at this time. Mexicans usually had awaiting them the lowest-paid, most menial tasks which were spurned by laborers from other groups. This development coincided with the low population density of the Southwest, the cutoff of Asian sources of workers, and the attraction of employment in other regions of the country for native laborers. Employers needed some group of people to work for them. This was a sine qua non for the physical development of the Southwest.

The urgent need for the bracero fit neatly with what society at large in the United States would accept in an immigrant group. The Mexicans in the Southwest worked and lived primarily in rural areas instead of congregating in the cities where their presence would be more noticeable. Moreover, since most did come to work only on a seasonal basis, the myth of the homing pigeon developed and grew. The aura of a potential cancer which could corrupt and destroy the civilization of the United States did not firmly take hold in the mind of nativists. The Mexican was already a familiar presence in the Southwest. What difference could a few more make if they were in the area for only a short period of time? 
This general attitude of unconcern was shared by policymakers in charge of immigration in the United States. These officials and members of congress had their attention drawn to other groups of foreigners from Asia and certain sections of Europe. Federal legislation during this period was designed to deal only with these two latter groups. The long-term implications of Mexican immigration were not thought out, and decisions regarding it were left to those presumed to know the most about it: southwestern employers. Nor did the braceros' home government seem to regard the population exodus as that important. Mexican leaders failed to show concern because of their preoccupation with the development of a laissez-faire model of capitalism. If this development led to the loss of a few lower-class Mexicans to the United States, that was the price which had to be paid. Capitalism, first through the destruction of the ejidos and then by accelerating emigration, thus proved to be the radical mechanism which aided in the free enterprise development of the Southwest. It was only after the Mexican elite realized that their own interests were being hurt by emigration that they evinced interest and attempted a policy of control. Their response, however, came too late to be effective.

These patterns of employment, settlement, and attitudes had established a system of immigration which could accommodate many more times the number of workers than had crossed the border before 1910. All that was lacking was the liberation of the majority of Mexican workers from the fields, factories, and mines. That liberation came with the Revolution of 1910. 


\section{Revolution and War, 1910 to 1921}

The second decade of the twentieth century saw the start of massive emigration to the United States. In Mexico the Revolution begun by Francisco I. Madero on November 20, 1910, initiated a ten-year period of instability and violence. Armies and bands of marauders numbering in the hundreds of thousands marched, countermarched, robbed, and killed over the face of the country. In the process, the civilian government was destroyed and agriculture and other economic activities were disrupted. The resultant inflation, starvation, unemployment, and lack of personal security forced upwards of 10 percent of Mexico's population, probably in excess of $1,000,000$ people, to flee to the United States. These displaced people found ready refuge across the border because of the continuing development of mining and agriculture. Native laborers had flocked to northern and midwestern industrial areas, and the national mobilization for World War I gave added impetus to labor shortages and the demands of employers for Mexican muscle to help provide the food and fiber needed by the western democracies. Policymakers in the United States, in order to meet these wartime demands and provide a haven for Mexicans, threw down the few bars that existed along the border. A special waiver to immigration laws was put into effect, and authorities winked at the almost daily failures to comply with even the minimal requirements of this program. Revolution and war, both of which so readily brought about social disequilibrium in both nations, thus neatly dovetailed to stimulate and enlarge the patterns and pathways of emigration which had come into existence before the Revolution of 1910 .

Díaz's remark that Madero had "unleashed a tiger" came close to the truth in describing the situation faced by the wealthy landowner from 
Coahuila and those leaders who later claimed the mantle of his revolutionary movement. For a decade after November 20, 1910, Mexico suffered the shocks and aftershocks of repeated civil wars and military rebellions. A detailed account of military actions from 1910 to 1920 would be beyond the scope of this study, but a brief outline of the campaigns of the various contending factions shows the near-pervasive destructiveness of the period. It was not until May 1911 that Madero and his followers toppled Porfirio Díaz and his top advisers from power. Military engagements during this first period of the Revolution were minor compared with later battles, but they were scattered throughout the entire country. Once he became president, Madero grappled with a series of revolts spearheaded by such leaders as Emiliano Zapata in Morelos, Pascual Orozco in Chihuahua, and Félix Díaz in Michoacán. General Victoriano Huerta's overthrow of the Madero regime in February 1913 turned loose all the destructive forces which modern warfare had made possible. Huerta's accession to power brought together a loose coalition of rebels headed by Venustiano Carranza. The Northern Dynasty wreaked havoc on Huerta's forces and the country in general.

In July 1914, Huerta went off into exile, but the hoped-for peace and national reconstruction of the men of the Northern Dynasty did not materialize. The rebels quickly split into warring factions which pitted the military genius Álvaro Obregón and Carranza against Pancho Villa and his sometime ally Zapata. Again, the nation was engulfed in civil war, and, as proved true in the campaign against Huerta, Obregón's self-taught military expertise aided his forces to win the day. By early 1917, peace of a sort prevailed in Mexico, and Carranza was elected president. Until he was ousted from power in May 1920, however, there was not a single day when someone was not in arms against the government. The ever-present acts of revolution and banditry caused a steady and massive drain on an already war-blighted economy. As the decade closed in 1920, Mexico was a devastated land. Perhaps 1,000,000 people, military and civilian, had been killed.

The mayhem born of the Revolution was particularly harsh for the lower classes of the country. Never secure even before 1910 , events after that year were all that were needed to plummet rural and urban workers to new depths of deprivation. Unemployment mounted quickly in all areas of the economy as the seemingly ceaseless warfare disrupted normal commercial activity. Work in all mines in Chihuahua, for example, came to a complete halt in 1915 because of the armed conflict between the forces of Villa and Obregón. Unemployment among industrial workers also mounted. This loss of security brought about a widespread epidemic of fear to many who were not in direct contact with any of the numerous military campaigns of the time. So great was this real or imagined fear of further social displacement that it became responsible for a high percentage of emigration to the United States. ${ }^{1}$

The most important impulse given rural migration by the Revolution was 
that it uprooted and set in motion hundreds of thousands of panic-stricken families. The bonds between hacienda owners and their peones were frequently broken as the latter joined marauding groups or fled the countryside for the safety of Mexican cities or the United States. Revolutionary chieftains in attempts to gain adherents, decreed sweeping changes in land and labor systems in the areas under their control. The Vera Cruz decrees, issued by Carranza in early 1915 at the low point of his political fortunes, were typical. Carranza declared the restoration of lands which had been taken away from the rural villagers contrary to the Reform laws and the abolition of the hated tienda de raya. There were two principal effects of these decrees. In areas already controlled by Carranza's forces, they served to legalize revolutionary measures in favor of the peasant class. In other instances, they had the effect of justifying the agrarian demands of other revolutionary leaders such as Zapata. Frank Tannenbaum has estimated that these abrupt changes in land and labor systems were responsible for the loss of over one and one-half million workers from the haciendas. ${ }^{2}$

Because of the ensuing land grab and the destruction of age-old institutions and relationships, few persons, peasant or landlord, could be assured of personal safety. A wholesale flight across the border into the United States followed. For example, in September 1912 the entire population of Villa Acuña, Coahuila, totalling 358 people, fled to Del Rio, Texas, in order to escape advancing orozquista troops. In October 1913, 8,000 people from Piedras Negras, Coahuila, found refuge in Eagle Pass, Texas. By the eve of Carranza's victory over Pancho Villa in 1916 tens of thousands of Mexican refugees from all sections of their country had emigrated to border cities such as Brownsville, Laredo, San Antonio, El Paso, Nogales, and Los Angeles. ${ }^{3}$

The experience of Pablo Mares was typical of many who fled across the border. Mares was a native of a small village near Guadalajara and, as a youth, had worked as a house servant on a hacienda. Shortly before the outbreak of the Revolution he set up a small retail store in his hometown. His dreams of advancement, however, were dashed in 1915 when a group of soldiers arrived one night at his store and demanded whiskey. The corporal in the group became angered when Mares told him he had no liquor, and tried to kill the storekeeper with his rifle. Early the next morning, Mares left his village as soon as he could and headed north. Another man, Luis Tenorio, also went to the United States from his native state of Jalisco after he had to join a military group. As soon as he had the chance he fled to Ciudad Juárez and crossed the border to El Paso. An emigrant from Querétaro probably expressed best the view of many people when he summed up his feelings in the following words:

I would like to go Mexico but I wouldn't go there to live because now I am used to this city [not identified]. What I don't like about Mexico is that they are fighting all the time, revolutions and revolutions. All want to be in power to rob and that is why the country doesn't progress. ${ }^{4}$ 
Not all emigrants were of the campesino or peon class. Hacienda owners who feared reprisals from their former employees also fled across the border. Once they were in the United States their circumstances often reduced them to the direst poverty. One landowner from the state of Sinaloa wound up in the county charity hospital in Douglas, Arizona, after he had broken his leg in an accident. Another wealthy man had been the mayor of a small town in the state of Durango and had enjoyed a comfortable income from several mines and pieces of land. When revolutionary violence broke out in 1911, the man, his wife, and children fled to San Antonio for fear their support of the Díaz regime would bring retribution. Military units which feared defeat at the hands of their enemies also sought refuge. In January, 1914, 5,000 of Victoriano Huerta's federal troops crossed the border and were temporarily interned at Presido, Texas. Typically, the soldiers were accompanied by a large number of camp followers. Regardless of their status in Mexico, the great majority of those who entered the United States soon fell on hard times and were forced to eke out an existence as best they could. José Puig Casauranc, the Secretary of Education under President Calles in the late 1920s, traveled to San Antonio in March 1915 and noted that low-paying, unskilled jobs were the principal livelihood of all the refugees. ${ }^{5}$

The near-collapse of agricultural production in Mexico continued to push people from the land. The wholesale flight of peones had left a labor force woefully inadequate in size to tend crops properly, and, with the threat of seizures of land or crops by peasants and revolutionary groups, landowners were unwilling to make the heavy investments of time and money needed for agricultural production. Furthermore, because of the general state of anarchy, there was no assurance that hacienda products would reach their intended markets. Peasants who had seized land for their own use often grew only what they needed to meet their own food requirements and had no surplus to sell. The hacienda system was virtually destroyed in many sections of the heavily populated central states, and much of rural Mexico reverted to subsistence farming or no farming at all. In many areas with high population densities, previously productive lands lay entirely abandoned. Statistics for the period are inadequate, but they clearly show a sharp decline in the food supply. According to one source, corn and bean production in 1918 was only 66 percent of the figures for $1910 .^{6}$

Mexico's rural and urban proletariat looked gloomily upon revolutionary chaos and its effects. These classes of society suffered disproportionately from the imbalances wrought by a decade of warfare, and it was only natural that they expressed despair for the future of their homeland. Only a small body of extant sources is available to gauge the emotions triggered by the chaos, and the corrido rates exceptionally high as a source of information. Corridos were ballads that commented upon or simply narrated contemporary events to the singer's audience. Since the majority of Mexicans were illiterate at this time, this form of music served as a news reporting and 
editorial service for them. The singers and listeners are essentially anonymous, and much of the subject matter of the songs is not subject to verification through the use of standard historical criticism. This body of literature does have value, however, because of the constant repetition of certain themes and ideas. This repetition of parts of the world view of the lower classes must be taken as affirmation of the authenticity of certain beliefs and attitudes. Hunger, in the stanzas of one corrido, had transformed Mexico into a living hell for the poor people. The singer went on to describe the lamentable condition of the "women of the plebe, desperate and hungry with their hair disheveled and beaten."7

The rampant inflation spawned by the Revolution also brought suffering and a further lowering of the standard of living inflicted upon the lower classes during the Porfirian period. Wages remained what they had been before 1910, but prices rose rapidly. One measure of the inflation was a government survey taken in 1920 which showed that prices for a large number of consumer items and foodstuffs in and around Mexico City rose from 100 index points in 1910 to 230 index points in 1920. In other parts of the nation prices for food reached such exorbitant heights that many of the bare necessities of life could not be had. Meat cost over $\$ 10.00$ a pound, corn sold for $\$ .50$ a pound, and beans could be had for $\$ 1.00$ a pound. In a lengthy study of the Revolution's overall impact on Mexican agriculture, government economist Fernando González Roa found that with the rising cost of food and the decline in real wages the majority of Mexico's rural inhabitants were literally dying of hunger. Similar hardships faced persons engaged in mining, industry and commerce. ${ }^{8}$

Carlos Almazán's story is typical of those who suffered economic hardships because of the Revolution. He was born on a hacienda in the state of Michoacán and fled to Mexico City in 1895 to escape his family's conditions of terrible poverty. He obtained employment in a butcher shop and within a few years thought he had carved out a favorable niche for himself. Almazán's hopes of security disappeared soon after 1910. First he lost his job in the butcher shop because his employer could not buy meat from farmers in the countryside. He then tried to buy fruits and grains from Vera Cruz for sale in Mexico City, but, because of the large amounts of worthless paper money in circulation, he was soon destitute. Left with no hope of finding work in Mexico, he and his family went to El Paso, Texas, where he quickly secured work as a track laborer for a trolley company. ${ }^{9}$

Many corridos express the widespread damage done to the lower classes by inflation. One composer blamed Carranza for the atrocious hunger suffered by poor people because "he circulated paper money with the most ferocious trickery." Once Obregón became president in 1920, the people looked to him to correct the still too high prices for the basic necessities of life. The following lines are typical of the lower class's frustrated hopes: 
Now what the people ask General Obregón

Is that prices are lowered in

Every part of the nation.

Earnings are not enough to live on

Because everything is so expensive. ${ }^{10}$

Another song expressed similar sentiments:

I ask in these verses

That General Obregón

Give relief to the poor people

In all parts of the nation.

That the price of food goes down

And the price of clothing is reduced,

So that the people, who are so on edge,

can live happily. ${ }^{11}$

As if widespread starvation and currency debasement were not enough to drive Mexicans toward the United States in search of refuge, the Revolution also destroyed whatever remained of civilian rule in Mexico. With the rulers of the Porfirian period gone, rural and urban districts came under the rule of the newly emerged revolutionary leaders. The new class of military bosses, in the words of Spanish journalist Vicente Blasco Ibañez, were little more than "rustic illiterates." They tyrannized the population in localities under their control, and sometimes killed people in drunken rages and arbitrarily seized their property. Even in areas not directly affected by revolutionary turmoil the uncertainty of what might happen caused many families to migrate from their homes. As Ernesto Galarza remembers the situation shortly after the overthrow of Díaz, "this great event was not the end of hard times... There seemed as much trouble ahead as there had been behind." In more prosaic language, one corrido singer suggested that whoever really wanted to make a contribution to the welfare of the nation should get back to where he came from and start tilling the land again. ${ }^{12}$

Constant fears for personal safety and private property were common in those areas which lacked even the most rudimentary organizations of law and order. This pervasive fear caused civilians to arm themselves at a truly alarming rate. Rifles and pistols were readily available because of the millions of weapons imported into Mexico by the various revolutionary factions. Harry A. Franck, who took an extensive tour of Mexico at the height of revolutionary foment, reported that in the state of Michoacán "gun toting" was limited among all classes of Mexican men only by the disparity between their wealth and the price of a weapon. One suspects that Franck was too conservative in his estimate of those who went about armed. Thousands of 
soldiers had returned from military campaigns with their guns as well as those taken from fallen enemies. Another eyewitness, Emile Dillon, a close friend of Obregón and a generally reliable observer of the Mexican scene, reported that from day to day "death or mutilation and robbery were contingencies about which one could never be sure" because of the presence of so many armed and desperate people. ${ }^{13}$

What relief could a Mexican worker seek from these horrendous conditions in his native land? Many, of course, stayed in the rural areas they had inhabited before 1910, but the potential dangers inherent in the unstable countryside surely made this alternative an increasingly dangerous one during the course of the decade. Many did flee to cities in Mexico, but, because of inflation and unemployment there, little could be found in the way of a stable, permanent resettlement. Side by side with the alternatives presented in Mexico was the possibility of emigration to the United States. As the decade unfolded this latter choice became more and more attractive to hundreds of thousands of displaced persons. Those who decided to exercise this option found that developments across the border greatly facilitated their access to this avenue of escape.

There was no obstacle to the refugee from Mexico in the immigration policy of the government of the United States. As discussed above, before the outbreak of the Revolution the conclusions of the Dillingham Commission had painted immigration from Mexico as a benign movement which presented little danger for the host country. When the Revolution in Mexico degenerated into anarchy, the United States Immigration Service readily allowed tens of thousands of braceros to cross the border, believing that they were temporary refugees and not permanent settlers. The offer of political asylum to half-starved and panic-stricken refugees was justified by the Commissioner General of Immigration as a "measure of humanity." By the middle of 1915, as the battle raged in Mexico between the forces led by Carranza and Villa, the Commissioner expanded the definition of "refugee" to include those suffering from "industrial depression and its attendant evils" because of the horrendous economic conditions brought about by the fighting. The influx of population from this open-door policy created large Mexican communities overnight in almost every town along the border. In order to alleviate overcrowding, find employment for the refugees, and meet the needs of southwestern employers, the Immigration Service worked out an arrangement with the United States Employment Service to move large numbers of Mexicans farther north from the immediate border area. The Employment Service sent information concerning the need for workers in specific agricultural areas to Immigration personnel. The latter then publicized job notices to Mexicans in search of work; on several occasions, federal officials aided employers in transporting laborers to job sites. These measures were carried out in the 
belief that once peace returned to the workers' native country, prosperity would follow and they would leave for home. ${ }^{14}$

Many frightened and destitute families also moved across the border seeking the relief services offered by social aid groups such as the Red Cross and Protestant missions. These organizations established ad hoc centers to supply food, clothing, and shelter for people streaming across the border. Once the initial needs of the emigrants had been met, many of the helping agencies sought permanent housing and employment for them. Protestant missionary workers proved to be zealous in their approach to incoming Mexicans. The Southern Methodist, Presbyterian, and Baptist denominations were especially active in El Paso, one of the major funneling points for the stream of migrants. The three groups, in cooperation with others, helped braceros with the hope of bringing them into their respective theological folds. The Revolution was seen by missionaries as a great jolt to the migrant's old religious and political beliefs, and it was hoped that they would respond to the example of Christian humanitarian assistance either through assimilation or as a friendly voice of the United States once they returned to their homeland. This aid and the policy of asylum, together with degenerating social conditions in Mexico with no immediate prospects of improvement, had the effect of encouraging thousands of temporary refugees to settle permanently in the states of the Southwest. ${ }^{15}$

Revolutionary violence and turmoil in Mexico coincided with rapid economic growth in the Southwest and encouraged more people to abandon hard times in Mexico for job opportunities in the United States. By the eve of World War I, big, irrigated cotton and sugar beet farms covered the river valleys of the Southwest. These farms had become like plantations and required large numbers of cheap, unskilled, migratory laborers. Railroads were in constant need of track crews to keep their rolling stock in proper order, and the mining industry continued to employ thousands of workers in pick and shovel work and in smelting work. Wages in the United States for these types of work continued to be much higher than those paid in Mexico and continued to provide an even more potent inducement to immigration and permanent settlement than had been the case before 1910. Almost any able-bodied rural villager or former hacienda employee could earn from $\$ 1.00$ to $\$ 3.00$ a day in unskilled agricultural work. If the bracero chose to work in mines near the border, he found even higher wages. Mexican miners in Globe, Arizona, for example, commonly earned $\$ 4.50$ to $\$ 5.50$ a day in local copper mines. Railroad track laborers earned $\$ 3.00$ a day or more. ${ }^{16}$

The economic mobilization brought on by World War I further accentuated labor shortages in the Southwest and in many other industrial areas of the country beginning in 1915. Over 1,000,000 citizens of the United States were conscripted for military service. Thousands of poor white and black laborers 
left the South and Southwest for cities such as Chicago, New York, and Detroit in search of better paying jobs which the war had brought into being. In many areas, only old men and women were available for stoop labor in the fields. This drain on the manpower of rural areas probably accounted for an exodus of perhaps $1,000,000$ workers. ${ }^{17}$

The extensive recruitment of Mexican workers was also encouraged by a sharp drop in European immigration brought about by the war and the Immigration Act of 1917. This law was based in part on the recommendations of the Dillingham Commission and was, up to that date, the high point of restrictionist legislation against southern and eastern Europeans. The Act imposed a head tax of $\$ 8.00$, and, for the first time, a literacy test which excluded many unskilled laborers who would otherwise have been admitted prior to 1917. Also excluded were those "who have come in consequence of advertisements for laborers printed, published, or distributed in a foreign country; contract laborers ... whether such offers or promises are true or false ...." These provisions, like those of the law of 1885 , were designed to halt the inducement of immigration by the direct or indirect assurances made by labor recruiters in foreign nations. ${ }^{18}$

The new law was effective in cutting deeply into the supply of laborers for many southwestern and western farms, mines, and railroads. Sugar beet growers and refiners in Colorado, for example, were no longer able to hire Germans and Russians to work in their fields. Farming interests in California were deprived of Italian, Slav, Greek, and Portugese workers. Immigration from southern and eastern Europe was reduced by almost 50 percent as a result of this legislation. This sharp decrease was in addition to the decline in immigration caused by the war. In 1914, 1,218,480 persons entered the United States; for the remainder of the war the annual number of immigrants hovered around the 300,000 mark. By 1918, after the implementation of the law of 1917, the annual number of immigrants was less than 10 percent of those in $1914 .{ }^{19}$

It also appeared that the number of braceros entering the United States would be sharply curtailed, since most of them were illiterate, could not afford to pay the head tax, or came through inducements held out by employers. There had been no special exemption to Mexican immigration in the law as had been the case earlier, and restrictionists had expressed the hope that their new legislation, passed over the veto of President Wilson, would reduce all immigration to the United States. For the few months during which the new exclusionary standards were applied along the border with Mexico, there was a sharp drop recorded in the number of legal entries. Only 31,000 Mexicans entered the United States compared with 56,000 for the same period in 1916. No information exists regarding illegal immigration, but the pressing needs for laborers in the Southwest leads one to believe that it was not much affected. The many opportunities for ready employment remained 
coupled with inadequate enforcement facilities and personnel. The handful of officials in the area were more attentive to the Asian immigrants and possible subversives from Europe than to braceros. ${ }^{20}$

Any reduction that occurred was only temporary. The law of 1917 nearly coincided with the entry of the United States into World War I in April 1917. Acute labor shortages began to develop almost immediately after passage of the law. Entrepreneurs in the West and Southwest were quick to point out to the federal government the possible consequences for the war effort if Mexican labor was not readily available. They argued that because of the wartime draft, the near-total elimination of European immigrant labor, and the flight to northern industries by native workers, agriculture would rapidly and totally collapse at a time when vast quantities of food and fiber were needed to feed and clothe men and women in uniform as well as the civilian populations of the United States and its European allies. Under the ninth proviso of the new immigration law the Secretary of Labor, at that time in charge of immigration matters, was authorized to set aside any of the law's provisions if he were convinced of a labor shortage in a particular sphere of the economy. Secretary Wilson was pursuaded by the contentions of employers, and on May 23, 1917, he specifically exempted agricultural workers from Mexico from any and all tests imposed by the Immigration Act of 1917. This waiver lasted until March 2, 1921, at the urging of employers of Mexican immigrants. Over 72,000 workers registered as entering under the terms of the waiver, but no one knows how many others, unregistered and unrecorded, came to work in agricultural jobs. All along the border anxious employers welcomed countless braceros whether they were registered or not. Immigration authorities made only minimal efforts to ensure full compliance with the program's provisions. ${ }^{21}$

Meanwhile, railroad, mining, and industrial interests pleaded for Mexican workers in the name of national defense. The United States Railroad Administration asked governmental permission to secure 50,000 track laborers from Mexico. One industrialist, apparently expecting a long war, suggested that $1,000,000$ braceros be recruited by the United States government to fill factory jobs throughout the country. Because of the concern expressed by these and other private employers, the Secretary of Labor extended his waiver in July 1918 to include nonagricultural workers. Braceros were allowed to work in railroad, mining, and construction work as temporary contract laborers admitted with no regard for the Immigration Act of $1917 .^{22}$ This waiver also lasted until March 1921.

By June 1918, even before the formal expansion of the waiver for agricultural workers, the number of incoming Mexicans was so large that the Department of Labor set up a formal structure to apportion arriving braceros to private employers. A labor council was established in El Paso, Texas, to represent agricultural, mining, and industrial interests. The sectors' agents on 
the council saw to it that their respective industries received a fair share of incoming laborers. Mexicans thus found it quite easy to move from unskilled agricultural work to a variety of wartime employment opportunities. ${ }^{23}$

At the same time, Secretary Wilson outlined procedures that employers had to follow in order to obtain workers under the waivers in force. To initiate the process the employer had to apply to the United States Employment Service or Bureau of Immigration and list the number of workers needed, the kind of work available, the wages paid, and the place of employment. Once permission to hire braceros had been granted to the employer, he could pick up his workers at any entry point along the border. He was then supposed to follow certain guidelines once the workers were at their place of employment. The Department of Labor standards included minimum levels of housing and sanitation, and a specific length of time that the workers were to be retained. Furthermore, the employer had to inform the Department of Labor if any workers left their place of employment in search of other jobs and to pay the costs of transportation back to the Mexican border. ${ }^{24}$

This program failed almost totally to live up to the established control guidelines. Remarkably, no governmental enforcement machinery was established to ensure compliance on the part of the employers. There was, instead, exclusive reliance on the goodwill of the involved parties without penalties for those who did not adhere to the stipulations of the Department of Labor. It must be presumed that the federal government did not wish to establish a layer of bureaucratic control over the agricultural sector. Any attempt to do this would have certainly run into resistance from farmers. It is also probable that federal officials tacitly assumed that the matter of Mexican labor could be best handled by those who traditionally had the most experience with it. This loose supervision of the program allowed it to serve as a "pump primer" for illegal entries. Once across the border, legally or not, Mexican migrants could with total impunity move from their original jobs to higher-paying work elsewhere. By late 1917 there were thousands of braceros who worked in factories as far from the border as New England and New York. Others worked in packinghouses, hotels, and restaurants in cities such as Chicago, New York, and Omaha, Nebraska. So many mine laborers emigrated that in one instance the Mexican consul in El Paso advertised in local newspapers for Mexican miners to return to their jobs in northern Mexico. ${ }^{25}$

There was little difference in employment patterns or settlement patterns between most of the true political refugees and the continuing stream of migrant laborers who, revolution or no revolution, eagerly sought better wages and employment opportunities. With the exception of several hundred middle- and upper-class families who settled permanently in border cities such as San Antonio, Laredo, and Los Angeles, most Mexicans who crossed the border during this period were not political exiles in the traditional sense of the word. They did not come to the United States primarily to practice a 
form of republican or democratic government or a form of religious devotion or to establish a model community or to escape persecution for political reasons in Mexico. They came to the United States driven by more basic human fears and hopes such as hunger, fear for personal safety, and the ever-present human desire for self-betterment as defined in the mind of each individual. Once in the United States the vast majority of Mexicans from the peon and campesino classes had skills which were of little value in a technological economy. They took common labor jobs in border cities or followed the paths already marked out to points in the interior by an earlier generation of Mexican migratory workers. Recruiting agencies in the border area also placed them on farms, railroads, and mines as well as in restaurant work or domestic service.

The Revolution provided a powerful stimulus to mass, permanent immigration from Mexico to the borderlands and from there to the interior of the United States. Many families decided not to return to Mexico even after peace was restored there after they discovered higher wages and more affluent living conditions in the United States. Other families, more indecisive, resided in border towns close to Mexico but also near jobs or migrant labor agencies in their new homeland, and so reinforced a settlement pattern and a unique pocho culture which was not quite committed to either country. Much of the fear and hostility deeply felt by many Mexicans toward Americans since the war between their two countries was partially dispelled by a long sojourn in border communities and in interior cities. Affluent social agencies, public and private, generally treated Mexican refugees and hapless migrant workers with sympathy and a degree of solicitous care unknown in Mexico at that time. Many Protestant groups spent the majority of their time and funds to secure living quarters and jobs for newly arrived migrant families. Word of the availability of well-paid work for the unemployed and generous, if temporary, aid for the refugees spread rapidly to thousands of families who sought work, security, or reunion with relatives already in the United States. ${ }^{26}$

The "draft scare" of the summer of 1917 indicated the desire and ability of the western business community and the government of the United States to induce braceros across the border for prolonged periods of time. The genesis of this crisis began with the Selective Service Act of May 18, 1917. Under the provisions of this law all adult males from twenty-one to thirty-one years of age were obligated to register for the wartime draft. All foreigners who resided in the United States and who had taken no steps to change their original citizenship had no duty whatsoever to serve in the military. They simply had to register with their local draft boards and offer proper proof of their national status. These minimal requirements expected of Mexican laborers had totally unexpected results. State and federal governments apparently had taken no steps to inform Spanish-speaking men of their status. Unfounded rumors and half-truths spread through towns and work camps of the West. 
Workers heard they would be drafted upon presenting themselves to their local draft boards and would be used as cheap cannon fodder while Americans stayed home and took advantage of war-induced prosperity. Few braceros who heard and believed these stories were about to risk death and mutilation for the Yankee behemoth. ${ }^{27}$

The initial responses of officialdom further tended to substantiate the rumors. Selective Service personnel began induction proceedings against thousands of braceros who did not have readily available certified proof of nationality. On many occasions Mexican consuls attempted to aid their fellow countrymen by issuing them temporary papers which attested to the bearer's place of birth. In some cases it even appears that overzealous consuls knowingly gave "proof" of Mexican birth to Mexican Americans who sought to escape the draft. Where this happened, Selected Service officials refused to accept any proffered consular proofs and initiated draft proceedings. ${ }^{28}$

Untold thousands of workers responded to the situation of uncertainty by voluntary repatriation. Along the entire length of the border United States immigration officers and employers viewed with dismay the quick loss of so many braceros needed for the domestic war effort. During the first five days of June, 5,451 repatriates streamed across the border; by June 11 another 4,000 had left the United States. Through the remainder of June and July the daily count of returning workers continued to mount ${ }^{29}$

Businessmen, employers, and those concerned with the war effort responded to the situation by near-hysteria. Local economic prosperity was heavily dependent upon the continued growth of agriculture and its related industries. With agriculture so heavily manned by braceros, it was obvious the repatriation would quickly push the local economy into a downturn. All interested parties soon turned to the government in Washington for a quick solution. Business groups cited the dangers to the border economy, saying retail sales would fall off as the numbers of braceros in their area lessened and the percentage of employer profits declined. The Eagle Pass, Texas, Chamber of Commerce earnestly pleaded for the federal government to do something, anything, so that "uneducated persons [could] remain in the United States." Groups of employers such as the Sugar Grower's Association, whose members employed thousands of braceros throughout the West, placed unheeded advertisements in newspapers, informing the workers of the true provisions of the draft law. ${ }^{30}$

Officials in the federal government were more concerned with the loss of braceros because of its possible implications for the war in Europe, and they moved quickly to stem the outward migration. An extensive propaganda campaign along the border advised Mexicans of the minimal requirements of the law. On telephone poles, billboards, train station walls, and stores, Spanish language posters informed braceros that they had nothing to fear: not 
one of them would be drafted. Secretary of State Robert Lansing also enlisted the aid of the Roman Catholic Church. All parish priests read a letter of assurance to their Mexican communicants. In many localities priests visited farms, mines, and rail camps to explain the position of the American government. Lansing also put his consular officers from northern Mexico into the campaign. All official personnel were ordered into the Southwest, where they were to make use of their Spanish language facilities and aquaintance with Mexicans to help stem the loss of workers. The United States government also called upon Mexican consuls for help. They too visited, at times with Catholic priests, with groups of workers and beseeched them not to retum to their homeland because of the congested travel facilities in northern cities and the impossibility of obtaining similar employment and pay once they left the United States. This latter effort seemed to have a marked effect in quieting fears about possible difficulties with the draft. ${ }^{31}$

The stream of repatriation diminished beginning in early August, and administrative changes were undertaken to facilitate the return of those who had fled and to encourage the entry of as many new workers as possible. Immigration officers on the border were ordered to aid the war effort and charge no applicable fees; few, if any, questions were to be asked of an individual's current or past draft status. The war effort had to be supported by large numbers of braceros if it were to succeed, and legal technicalities were not to obstruct the more pressing needs of the moment. By August 21, 1917, personnel directing the campaign to retain Mexican workers declared their efforts to be a total victory. Consul General Hanna wrote to Lansing that the labor supply had been sufficiently increased so that agricultural laborers were "plentiful" and railroad lines were "better supplied" with migrants for all types of work. In July 1918 the government suspended even the minimal obligations of Mexicans under the draft law and no longer required them to register for the draft. This latter action was not carried out in an attempt to check wartime repatriation but as an inducement to the continued emigration of labor for the war effort. ${ }^{32}$

The responses of summer 1917 provided clear insights into the attitudes of the government and business community of the United States in relation to Mexican labor in the West and Southwest. It was evident that almost every sector of the economy, especially in areas close to the border, depended heavily on the bracero. Without the continuing inflow of large numbers of unskilled laborers from Mexico, the Southwest's contribution to the war effort would probably have collapsed. Had this not been the case the public and private response to repatriation would not have been so quick and determined. By 1917 this fact of economic life was well known to officials in Washington. Their wartime policies had been formulated and effected with these considerations in mind in order to sustain the prosperity of the area.

The volume of Mexican immigration continued to be so large after the 
end of the war that braceros in search of employment faced little competition from native labor. Many blacks and poor whites remained in the North after the war, and most homecoming soldiers did not seek stoop labor or pick and shovel work, especially when continued industrial prosperity offered better employment opportunities. The shortage of common laborers continued and the government of the United States found it was confronted with myriad demands for more laborers from Mexico. Several western senators and the United States Sugar Manufacturers' Association, for example, claimed that severe manpower shortages in early 1919 would seriously impair the supply of sugar beets for that year. In January, prompted by these and other pleas from other spokesmen for agriculture and industry, the Secretary of Labor allowed as many braceros to enter the country as needed by domestic businesses. This was done through the simple extension of the wartime waivers. Later, another extension was effected with the acquiesence of Congress after it had conducted extensive hearings on the matter ${ }^{33}$

An unprecedented jump in legal migration from Mexico rose from wartime employment opportunities, postwar prosperity, and the diminution of other sources of foreign labor. Employers sponsored the entry of Mexican workers, and Secretary of Labor Wilson, in view of the economic needs of the West and Southwest, cooperated with them. In the two years following the conclusion of the war, almost 150,000 Mexicans legally crossed the border. Important sectors of the economy had become completely or heavily dependent on Mexican migrant labor, particularly in the Southwest. Braceros constituted the majority of unskilled laborers in agriculture and were to displace nearly all other groups in the decade that followed. It was rare not to find Mexican workers in other areas of employment, often in locations far from the border. ${ }^{34}$

Statistics of immigration from the 1910-20 period show a remarkable rise in the number of legal entrants admitted from Mexico. These official figures can be taken only as a partial measurement of immigration because of the United States' policy of asylum, the wartime need for braceros, and the large numbers of wetbacks. Concerned personnel in both nations rejected outright the official statistics of the population flow. The Assistant Chief of Staff for Military Intelligence for the Southwest estimated that from February 1 to March 19, 1920, alone, over 100,000 laborers crossed the border illegally. This estimate, and others contrast sharply with the data from the Annual Reports of the Commissioner General of Immigration shown in Table 3.1.

Census data from 1920 provide additional proof that the number of immigrants was far in excess of officially recorded statistics. A total of 651,596 Mexicans and their children were counted by enumerators on January 1, 1920. This count was plagued by many of the technical problems encountered in 1910. More importantly, the date chosen by the Bureau of the Census was in a time of the year when the Mexican migratory population was at its lowest point, after the completion of the harvesting season and before the start of 
spring planting. Within a few weeks of the census date hundreds of thousands of seasonal migrants began to pour across the border in search of employment. This group of workers and their familes were therefore absent when the enumeration was taken, and their absence diminishes the true size of the Mexican community. The reported total of 651,596 is of itself significant. This represents an increase in population of 437,321 people when compared with the 224,275 which had been reported ten years earlier. It is probable that by midsummer of 1920 , at the height of demand for workers, the number of migrants in the United States was near or slightly above the 1,000,000 mark. Robert McLean, who worked for many years as a Protestant missionary with Mexicans along the border, believed that as early as 1916 the bracero community in the Southwest was in excess of 500,000 . It is possible that with the growing stream of expatriates in the immediate postwar period that the number of border crossings during the entire decade by individuals who either remained in the United States or returned to their native land was nearer a total of $2,000,000$ than the 330,000 counted by United States immigration officials. ${ }^{35}$

This rapid growth in the size of the Mexican and Mexican American community within the United States because of the migratory process was well underway before the outbreak of the Mexican Revolution of November 20, 1910. Revolutionary violence and its aftermath merely caused larger numbers of people to join the stream of population which had crossed the border beginning around the turn of the century. The strongest effect of the Revolution was that it freed countless thousands of rural and urban inhabitants from their miserable places of toil and living. The "epic phase" of the regeneration of Mexico allowed many of these newly freed people to take

TABLE 3.1

Legal Mexican Entrants Into the United States, 1910-20

\begin{tabular}{cccc}
\hline $\begin{array}{c}\text { Year Ending } \\
\text { June } 30\end{array}$ & Immigrants & Non-Immigrants & Total \\
\hline 1910 & 17,760 & 3,327 & 20,997 \\
1911 & 18,784 & 3,581 & 22,365 \\
1912 & 22,001 & 3,701 & 25,702 \\
1913 & 10,954 & 4,541 & 15,495 \\
1914 & 13,089 & 3,990 & 17,079 \\
1915 & 10,993 & 7,649 & 18,642 \\
1916 & 17,198 & 7,963 & 25,161 \\
1917 & 16,438 & 9,442 & 25,880 \\
1918 & 17,602 & 14,147 & 31,749 \\
1919 & 28,884 & 15,932 & 44,776 \\
1920 & 51,042 & 17,350 & 68,392 \\
\hline
\end{tabular}

Adapted from Commissioner General of Immigration's Annual Reports from 1910 to 1920; idem, Annual Report, 1920, pp. 707-21; James Davis, Secretary of Labor, to Representative Cole, April 25, 1924, in Congressional Record (January 6, 1925), pp. 1366-67. 
advantage of the pre- 1910 avenues of escape and economic betterment laid out by an earlier generation of emigrants. What the Revolution did bring during its first decade was decidedly unappealing. Inflation, food shortages, military rule, loss of land, and the possibility of death or mutilation gave added causes for fleeing Mexico for the safety of the United States. The mass migration of braceros to the Southwest and from there along the railroad arteries to the interior seems in retrospect to have been inevitable. A massive labor exodus to the United States probably would have occurred in the period after 1910 with or without the Revolution. The latter must be viewed not as the primary cause of emigration, but only as an additional circumstance which prompted the labor exodus.

Strong attractions for Mexicans appeared side by side with social and economic degeneration in their homeland. Prior to the stimulus to the economy provided after the early phases of the European war, the continued expansion of southwestern agriculture, mining, and railroads created a heavy demand for bracero labor. Manpower shortages intensified after 1915 as native farmworkers and other employees migrated to industrial centers. The year 1917 is a watershed in the history of Mexican immigration because of two important events. The wartime draft aggravated already precariously low supplies of workers in certain sectors of the economy, and the Immigration Act of 1917 further lessened the competition for employment that braceros faced once in the United States. Mexican workers inexorably and inevitably moved into the accelerating vacuum of labor created by these two events.

This could not have happened without the cooperation of the government of the United States and its officials. Still convinced of the essential correctness of the view that held Mexican immigration to be only of a temporary nature, officials threw open border ports of entry to hundreds of thousands of panic-stricken refugees fleeing the conflagration of warfare and then the aftereffects of industrial depression. This open-door policy was in essence designed to extend humanitarian aid to Mexicans. That they aided the domestic economy was viewed as beneficial but only secondary. The need for labor quickened beginning in 1915 and greatly accelerated in 1917 when the United States entered the war. The wartime waivers and careless attitude concerning the enforcement of other immigration legislation showed the intention of the government to use Mexican labor to the fullest in order to ensure a successful conclusion of the war. Indeed, the contribution to the Allied cause provided by braceros was of singular importance. Without the Mexican, who would have provided the human muscle to produce the food, metal, and fiber for the United States and its allies? The techniques employed by the government of the United States, however, were only a small part of official attempts to exercise control over Mexican immigration. The braceros' home government also made Herculean efforts to establish itself as an active participant in controlling the outward flow of population. 


\section{4}

\section{Labor Emigration to the Southwest, 1910 to 1920: Mexican Attitudes}

Emigration was widely recognized as a problem of national urgency as Díaz left Mexico for Paris in May 1911. Reformers and political dissidents had earlier cited the loss of laborers as a national disgrace. For these reasons, the Madero government immediately gave its attention to developing some sort of response which would bring back those braceros already in the United States and prevent more workers from leaving their homeland. In this springtime of the Revolution, many proposals were thrown out for discussion; some laws were put on the books; high hopes for a new Mexico without the shame of emigration were raised in many quarters. The nationalism and mestizo consciousness spawned by Madero's successful overthrow of Diaz had given rise to their necessary corollary of the repatriation of Mexicans forced to go abroad to earn their daily bread.

Those concerned with population losses were wont to analyze the causes of emigration and propose possible solutions to a degree unheard of in pre1911 politics. Most of the blame for the loss of braceros was rightly placed on the land and labor systems imposed upon rural Mexico by the hacienda. The low wages, brutality, near-starvation, and lack of sufficient employment were not secrets to the leaders who took over the government in 1911. At issue was the question of what kind of land or agrarian reform was needed, and the early days of the Revolution clearly showed there was no consensus. Emiliano Zapata and his followers saw the answer in clear, if not simplistic terms: the immediate restitution of the ejidos to the peasantry of Mexico. Luis Cabrera supported this contention in December 1912 from the floor of the congress when he spoke in favor of legislation designed to check emigration by establishing some ejidal holdings. Other proposals included the establishment of 
homesteads patterned upon the model of the United States' rural development in order to fix securely a domicile for Mexico's rural poor. Rafael Hernández, Madero's Secretary of Development, called for the government to acquire private property and then sell the land in small parcels to braceros who wished to return home. Victoriano Huerta's Secretary of Finance, Toribio Esquivel Obregón, later agreed that this was a proper role for the Mexican government. ${ }^{1}$

This wide spectrum of opinion did lead to a modest legislative program. A law of December 18, 1911, empowered the executive to aquire property for the purpose of encouraging repatriation of braceros. In November 1911 the federal Department of Labor was created. One of the intentions of congress in establishing this office was that emigration would be checked through the creation of a nationwide system of employment offices which would match workers with available employment. This would mean there was no need to emigrate in search of work. Officials within the Ministry of Development strongly urged quick congressional passage of this latter law. To fail to do so, they argued, would negate all of the best intentions and hopes of Madero's regime. Only when the bracero could dress as well as the returning worker and have just as much money in his pocket, could the Revolution be considered successful. ${ }^{2}$

Little could be done to implement these laws during the fifteen months of Madero's presidency. Madero did return one group of laborers from El Paso in January 1912 under the power granted to him by the legislation of the previous month. A group of 296 people were sent to their homes in the central part of Mexico with the expectation of receiving land parcels from the government at a minimal cost. Apparently, this group never established an agrarian colony because the government lacked the funds to make the initial purchase. Nor was there enough money to set up a coordinated campaign to find employment for would-be emigrants. One policy that the Madero government did continue from the days of Porfirio Díaz was the wide dissemination of notices which described unfavorable conditions for braceros in the United States. ${ }^{3}$

These minimal accomplishments from December 1911 to February 1913 must not obscure the important transition which took place. There had been positive attempts to establish bureaucratic and statutory controls over emigration, but those efforts had largely failed because of the lack of resources and the short tenure of the Madero regime. Had he been allowed to serve out his entire term it is possible that long-term programs could have been established which would have significantly altered the history of emigration for the remainder of the twentieth century. The assassinations of Madero and his vice president Pino Súarez, however, plunged Mexico into as near total chaos as any nation has undergone in this century. It was the anarchy of revolution and the ensuing disequilibriums in society which accounted in large part for the responses of post-Madero governments to emigration. What had changed by 
February 1913 were certain attitudes and beliefs of revolutionary leaders. Emigration was not desirable and could not be ignored, as was the case during most years of the Porfirian regime. Instead, the loss of nationals to the United States began to receive the attention it merited. Mexico's strength lay partly in her people who were sorely needed for national reconstruction. The plans and schemes of governments before 1910 to induce European immigration had largely failed. If Mexico was to prosper, it was to be through the efforts of the Mexican people. Any government which accepted the mantle of revolutionary legitimacy had to deal with migration in such a way that Mexico's vital national interests were given primacy.

Venustiano Carranza, first chief of the Constitutionalist Army and President of Mexico from 1916 to 1920 , became the first leader to attempt to slow down and regulate the exodus of Mexican laborers to the United States. This policy consisted of two major parts: advising would-be emigrants of the pitfalls which awaited them across the border and protecting those who had already left Mexico. Mexican authorities could do little to keep their fellow citizens at home. Economic developments in both nations were the determinants of emigration. The asylum policy of the United States, manpower needs in southwestern agriculture, and mobilization for World War I brought about the influx of hundreds of thousands of unskilled workers. Mexico's revolution-wracked economy gave braceros added cause to flee. Carranza and his government officials sought to protect Mexicans in the United States once it became evident that administrative controls were not sufficient to keep nationals at home. This protective policy was severly restricted because of lack of funds and shortage of consular personnel, but it did meet with some success, particularly in the areas of employer-employee disputes and difficulties with officials of the United States Selective Service system.

Carranza's government had to take into account strong public sentiments when it formulated its policy toward expatriate nationals, for massive emigration was a matter of serious concern to Mexican government officials, employers, and nationalists, even in the midst of many other pressing revolutionary problems. On the one hand, many observers believed that certain benefits accrued to Mexico and her people as a result of extensive contacts with the culture and civilization of the neighboring United States. As early as May 1913, Manuel Bonilla, Madero's Secretary of Development, pointed out that former hacienda workers found good working conditions across Mexico's northern border. In the United States one did not have to face starvation or brutal treatment by employers. Bonilla concluded that the experience of being near an advanced culture aided emigrants in improving their own life styles. Later writers elaborated on the cultural benefits to which Bonilla had alluded. An editorialist of El Universal, one of the leading dailies in Mexico City, believed that the peasantry learned how to be temperate, to dress well, to eat properly, to speak English, and to employ the latest agricultural 
techniques and machinery. When the migrants returned to their homeland with their new skills, they were cultured persons and a progressive element for Mexico. ${ }^{4}$

On one occasion, even Carranza's government officially praised the cultural benefits and progressive attitudes supposedly manifested by returning nationals. Undoubtedly, this finding favor with labor expatriation was, in part, a defensive attitude. The government was embarrassed by the fact that Mexican citizens, especially those of the peasant class, were forced to go abroad to seek their livelihood. It was an open admission to the world that Mexico reborn could not yet take care of her own people. What benefits did the Revolution provide for the humble lower classes? The government could at least reply weakly that emigrants in the United States were enjoying the benefits of temporary refuge. ${ }^{5}$

On the other hand, most available sources of information suggest that the majority of literate Mexicans were totally opposed to emigration. Revolutionary nationalists were convinced that Mexico was underpopulated and that this fact had frustrated economic growth and national security in the past. Emigrants, therefore, were traitors to the fatherland. Just when their own nation was in need of their labor and support, they deserted Mexico and went to provide benefits for the Yankee colossus. Nationalists also believed that the flight of labor had weakened industrial development because of the exodus of much-needed technicians. Agricultural production was in a very grave state, according to Secretary of Development Lugo, because of the lack of workers needed for proper cultivation. This nascent populationist policy of the Revolution of 1910 was best expressed in 1915 when a spokesman said that demographic increases were the "greatest and most effective growth of [Mexico's] riches." Many other people lamented the personal hardships imposed on emigrants. Presidential candidate Álvaro Obregón, for example, implicitly criticized the Carranza government in November 1919 when he railed at the spectacle of freight cars full of Mexicans being taken by labor recruiters from Nogales, Sonora, "like penned cattle." He then observed, "To go to a foreign country men have to sell their sleeping roll, a burro, and even the beams of their home for firewood, attracted by the sweet promises of the labor recruiters. When they return, there is no longer sleeping roll, nor burro, nor home." 6

In addition to inflammatory responses from other political leaders, the Carranza government was obligated to take a strong course of action because of certain provisions of the Constitution of 1917. This document was the basic statement of some of the ideas of the Revolution, and its tone of belligerent nationalism made it the lodestar of any leader who laid claim to revolutionary legitimacy. Section 26 of Article 123 dealt specifically with emigration. It dictated that municipal authorities must insure that each departing bracero have a signed contract which spelled out his rights in the United States. Since 
this provision for a contract was within the broad array of protective legislation of Article 123, the emigrant was to enjoy a minimum wage, maximum hours, medical care, and equal treatment with fellow employees. The employer was to pay all costs of repatriation from the United States and was forbidden by section 26 to charge any fees to the pay of his workers. The committee that wrote these provisions expressed a strong desire to halt abuses against Mexican workers who had crossed the border, and their recommendations to the constitutional convention at Querétaro were approved without discussion. ${ }^{7}$

Public opposition to emigration was so vehement that the Carranza regime felt obliged on several occasions to defend its policies. At least, stated an editorial in the Diario Oficial in November 1917, officials aided returning workers by giving them free railroad passes to their homes once they had crossed the border to their homeland. Previous administrations had wasted their time and money in futile attempts to induce white European immigration, but the minimal assistance extended by the Carranza government to repatriates quickly and surely aided in the reconstruction of Mexico. On two occasions in March 1920 a spokesman for the Secretary of the Interior indignantly denied the government had been indifferent to the fate of expatriates. On March 17 an article reprinted some of the circulars sent to Department of Migration officials at border points. These documents were offered as proof that strenuous efforts had been made to protect workers by allowing the exit of only those protected by contracts and warning of areas in the United States where Mexicans were ill treated. An editorial in the Diario Oficial on March 23 stressed the government's intentions to continue protecting poor workers, who often lacked the means to look after their own interest. On this occasion, the writer even invoked the principles of Pope Leo XIII's encyclical Rerum Novarum which called for the paternalistic protection of the lower classes by the state. ${ }^{8}$

In spite of conflicting opinions, national political leaders believed that emigration should and must continue. Carranza's government had to face several pressing realities in formulating a policy that sought to profit from the population exodus and at the same time to control it. Economic conditions in Mexico during this period were obviously deplorable, and most of the lower classes were suffering from elemental wants. Any money sent by relatives from the United States would help greatly to alleviate their poverty and suffering. While no official spokesman ever said so publicly, Mexican administrators were inclined to regard emigration as a political safety valve. Miserable have-nots and potentially dangerous rebels and demagogues might support or seek to lead armed protests against the often shaky government. In fact, Mexican consuls and Migration personnel frequently did all they could either to keep braceros in the United States or to facilitate their re-entry into that country. Braceros who had been deported, for example, were immediately 
issued Mexican passports so that they might legally recross the border and resume their employment. During the draft scare of 1917 , discussed above, Mexican officials acted decisively to effect the stay of their conationals in the United States. One tantalizing event indicates that Carranza may have used emigration as a bargaining chip in diplomatic negotiations. In July 1918 the American government announced that it had lifted its arms embargo against Mexico. Officials in Mexico City told reporters they were pleased with the decision and planned to provide a train to take a large number of braceros to Laredo, Texas. All political considerations aside, to force braceros to stay at home would only expose them to "absolute misery," as one Migration official on the border frankly stated. ${ }^{9}$

Mexican nationalists and employers also urged their government to blockade the northern border. This could have been done on the grounds of fighting United States imperialism. Military incursions into Mexico had taken place on several occasions in attempts to protect United States nationals and to influence the course of the Revolution. Many not too subtle attempts to interfere in Mexican domestic matters had been made through diplomatic channels. Carranza, however, could not adopt this proposal. His regime faced political enemies on all sides and had few troops to spare for border watching. Recognition, support, and arms were sorely needed from Washington as props for his revolutionary government. Furthermore, the government felt obliged not to contravene Article 11 of the Constitution of 1917 which granted citizens the right to enter and exit their country subject only to administrative restrictions and procedures. ${ }^{10}$

Emigration was also considered to be only temporary by most policymakers in the Carranza administration. This provided an additional reason for the mild responses of the government to population losses. It was believed that, once peace returned to Mexico, industrial and agricultural prosperity would supply sufficient employment at home for braceros. The worst of the military campaigns were past, rampant inflation had slowed, and the country had been provided with a legislative framework for future development by the Constitution of 1917 and Carranza's implementing decrees. Jesús Acuña, Carranza's Secretary of Interior from February 1913 to November 1916, claimed in 1933 that his chief's protective legislation for Mexican workers was designed, partially, to offset the attractions of employment in the United States. Pastor Rouaix, Secretary of Agriculture, believed that once the monopoly of the hacienda on the countryside had been broken, emigration would end. In one of his few public pronouncements on the matter, Carranza said it was natural to hope that "with the return of legal order all expatriated Mexicans would return to their homes." Privately Carranza told American Ambassador Fletcher that he was only too happy to see the underfed, underpaid Mexicans go to the United States in search of work provided that American Selective Service officials left the braceros alone. ${ }^{11}$ 
The government sought a middle course of policy which would placate, at least partially, all interested parties. The moderation of beliefs on the part of most policymakers dictated that the more extreme steps advocated by certain individuals were not to be taken. If emigration was only temporary, there was no reason for undue alarm. One basic thrust of the regime's response began in late 1916 when, on the advice of the governors of the border states, an intensive propaganda campaign was launched to advise would-be emigrants of the prejudice and exploitation faced by Mexicans in the United States. From Carranza's partial pacification of the country in 1916 until his overthrow in May 1920 a stream of news items unfavorable to bracero conditions across the border poured forth in the news media and in governmental publications. A typical example of this propaganda appeared in the Diario Oficial of March 10, 1920. The Mexican reader was told that emigration per se was not harmful, but that braceros were subject to rampant racial discrimination, received lower pay for doing the same types of work as American citizens, and were treated unfairly by police and court agencies. The article went on to say that since 99 percent of all immigrants were ignorant of United States immigration laws they were often stopped at the border and forced to congregate in border cities such as Nuevo Laredo and Ciudad Juárez. Once there, without friends, family or money, the workers formed large "parasitic masses" on the verge of starvation. The natural result of the situation was that many tried to cross the border illegally. If this step were attempted, workers ran the risk of being shot by United States border patrol authorities. Those who succeeded in their clandestine efforts then faced multiple instances of ill-treatment and the much greater danger of Americanization. Everywhere in the Southwest, concluded the article, Protestant missionaries in league with the general American citizenry sought to deprive the bracero and his family of their native culture and religion. Other articles claimed that with the end of World War I hundreds of thousands of returning veterans had resumed their prewar employment, leaving few, if any, jobs for braceros. If Mexicans wanted work, they would be better off to look for such opportunities in their own homeland. ${ }^{12}$

The propaganda campaign made selective use of consular reports sent to the Secretary of Foreign Relations. Once a particular report-or parts of it-had been approved by the Secretary, it was given wide circulation through newspapers. State governors were also informed of anti-Mexican conditions in the United States and were charged by the federal government to make known to all of their states' inhabitants the "penalties and miseries" which awaited braceros across the border. All federal employees, especially those in the Secretary of the Interior's Department of Migration, were also to give warnings to would-be emigrants. Almost all reports from the Secretary of Foreign Relations placed special emphasis on the broken promises of employers. Arizona cotton companies were frequently singled out as prime culprits in this regard. They were accused of inducing workers to cross the 
border with promises of high wages and good working conditions, and then, with an excess number of braceros on hand, exploiting them. The result for the expatriates was a disastrous situation of unemployment or substandard wages wherein hapless migrant workers, far from home in a strange, hostile country, often faced starvation..$^{13}$

Law enforcement officials were also attacked for using high-handed methods in dealing with Mexicans. United States immigration authorities were accused of arresting migrants, dumping them arbitrarily over the border, and leaving them to their own meager resources, which resulted in great hardship. According to other published reports, police officers, local and state, frequently committed atrocities against defenseless Mexican workers. Alberto Ruiz Sandoval, the consul in El Paso, for example, wrote that police agents in that city killed 391 Mexicans in the short period from 1911 to 1919. ${ }^{14}$

This intensive propaganda campaign had little effect on emigration to the United States. The vast majority of rural Mexicans were illiterate, and it is doubtful that they were much influenced by written government news notices. What had a more decisive influence was the "grapevine." There is no doubt that many of the instances of unfair treatment were true, but they represented only a part, perhaps a small one, of the bracero experience in the United States. Returning workers generally painted glowing pictures of better living and working conditions across the border. Besides, the worker more often than not distrusted his own government, whose agents seemed always to exploit him and protect the employer class. Why, now, should one believe in the protective efforts of untried revolutionary regimes? Why stay at home and face possible starvation or violent death? If the United States employers and officials occasionally abused Mexicans, the workers' experiences with employers and officials in their own country had taught them how to deal with such treatment. As Consul Cornelius Ferris of Mexico City wrote concerning the propaganda efforts of Carranza's government,

\footnotetext{
... such representations made by the Mexican authorities make very little impression on Mexicans of the laboring classes. At San Luis Potosí, especially during the year of 1918, I examined hundreds of Mexican applicants for passport visas .... Nearly all had friends in the United States .... [They] told me that they placed no reliance whatever on representations made by their own government officials, and they felt assured of good treatment in the United States. ${ }^{15}$
}

Many other consular dispatches recorded the same beliefs concerning the propaganda campaign, but perhaps no more eloquent testimony is needed as to its failure than the rising tide of emigration.

Carranza's government also sought to regulate the outflow of laborers 
through a series of administrative procedures. One policy decision was to leave in the hands of state governors the issuance of passports needed by braceros to leave the country legally. Presumably, local politicians were more aware of the effects of the loss of laborers to their states and were better able to enforce the dictates of the central government. Jalisco, one of the states in the central plateau which provided a disproportionate percentage of workers who went to work in United States agriculture, attempted a policy of uniformly denying passports because of the chronic complaints of labor shortages made by local industrialists and agriculturists. United States consular officials, especially during the acute labor shortages occasioned by World War I, totally defeated the state's intentions by privately encouraging braceros to go to the border without passports, knowing that at the border they would be readily admitted. ${ }^{16}$

State governors were also under orders from the central government to take active measures to discourage emigration by whatever steps they deemed necessary. Not only did state officials give wide publicity to the propaganda from Mexico City, but some tried to stop labor recruiters who boldly invaded their states during the war in search of braceros. In one case, a representative of Arizona cotton growers who was seeking helpers to harvest crops under authorization from Secretary of State Robert Lansing was forbidden to carry out his work in the state of Sonora by Governor Plutarco Calles. Calles told the recruiter he could contract for workers only if his employers posted a bond of $\$ 1,000$ for every man induced to go to Arizona. In this way, Calles hoped to discourage the recruiting of large numbers of Mexicans and at the same time to ensure that the cotton companies honored all their promises and guaranteed the return passage of workers once the harvesting season was completed. Lansing, when he heard of Calles's demands, refused to intervene through diplomatic channels and presumed that the growers would obtain all the help they needed through the normal flow of braceros once news of the work available in Arizona was made known to Sonorans. ${ }^{17}$

For these reasons, Mexico's central government under the guidance of Venustiano Carranza failed almost totally to reduce the volume of labor expatriation or to protect by contractual arrangement those who did emigrate. A few individuals were doubtlessly persuaded not to leave their nation, but their number was small, if not insignificant. The human desires for security and self-betterment controlled the decision to emigrate or not to emigrate. Those who saw little chance for immediate improvement of their lot in Mexico and wished to go to the United States followed the lures of peace, money, and employment as their alternative to the situation at home-not the stories of Carranza's government.

Unable to control the steadily increasing number of emigrants, the Mexican government tried to secure favorable work contracts for its nationals 
before they left Mexico. Beginning in January 1917, Department of Migration inspectors were ordered to prevent the exit of any worker who did not have a signed, valid, and written contract in accordance with Article 123 of the Constitution of 1917. The document had to contain specific provisions as to wages and hours and would not be binding on any of the concerned parties unless an employee of the Migration service witnessed its signing. Later in the year inspectors were instructed to tell all emigrants to register with the nearest Mexican consul once they were in the United States. Once this had been done diplomatic officers could make sure that employers complied with all of their contractual promises. ${ }^{18}$

The federal government published a model contract in March 1920 which was intended as a remedy for complaints concerning mistreated Mexicans in the United States. This document also provides a good illustration of the protection which revolutionary leaders hoped to give to the emigrants. No bracero could leave Mexico unless he was protected by this document and accompanied by his family. Presumably, this would act as a brake on attempts to corrupt or Americanize peasants and prevent families from being abandoned in Mexico. Transportation costs to and from the place of employment were to be paid by the employer, who was also obligated to pay all entry fees levied by United States law for the worker and his entire family. Detailed working conditions were also spelled out. The minimum wage was set at $\$ 2.00$ a day, and free medical care was to be provided for those who suffered a work-related accident. Any worker disabled in the course of his employment was to be repatriated at the employer's expense. Several enforcement procedures were also stipulated in the suggested contract. Before the worker left his native state, his employer had to sign a notarized agreement in the presence of Department of Migration and state officials and post a bond to guarantee compliance on his part. Once the worker was at his place of employment the nearest Mexican consul was to act as a watchdog over the employer. National railroad companies were also charged with the responsibility of enforcing this contractual relationship. Trains, the major form of transportation to the north and over the border, were to be constantly policed so as to halt would-be emigrants who did not have contracts. ${ }^{19}$

This administrative effort also failed. Peasant mistrust of the government helped cause the failure, but a more basic reason lay in the attitudes of Department of Migration officials. Many, for humanitarian reasons, felt they could not deny their countrymen a chance for a better life. Many more, if not most, according to the accusations which poured out of Mexico City, took advantage of the situation for self-enrichment. They regularly cooperated with enganchadores and professional smugglers of aliens by serving as contact men for workers who wished to cross the border. ${ }^{20}$

The naiveté of the framers of this model contract is so striking that it raises questions as to their true intentions. Any employer who signed this document 
went on record in a signed and sealed legal paper as having violated the United States Immigration Act of 1885 which forbade the inducement of immigration by prior contract. Moreover, no state jurisdiction in the United States provided, by law, any of the work guarantees for agricultural workers mentioned in Article 123 of the Mexican constitution. Did the contract's framers truly believe they had the power to legislate social provisions for workers in another country whose climate was in many ways antithetical to those ideals? It is doubtful that more than a handful of employers would seriously have considered the extension of these benefits to braceros. In fact, no instance of an employer's signing this document has come to light. The easiest and most profitable tactic was simply to ignore the designs of the government in Mexico City. It is probable that the publication of this contract was designed more to pacify domestic critics of the Carranza regime's emigration policy than to give the specified protection to braceros.

The protection of workers already in the United States was another concern of the Mexican government, and it was here that the most success came about. So many nationals found immediate employment across the border that officials were forced to take a realistic view of the situation. As Secretary of Foreign Relations Cándido Águilar expressed it in September 1917: " since it is not possible for the government to prevent emigration, it must make every effort to bring about the least possible suffering for our conationals during their stay in a foreign land.' In fact, this policy of consular protection antedated the Constitution of 1917 and had been in evidence since November 10, 1916. On that date Mexico's diplomatic representatives in the United States were ordered to use the full powers of their offices and all legal resources available to aid their fellow countrymen. They were to visit jailed migrants and inform them of their rights under local law and see that those rights were respected. This was to be done by contacting police and court agencies to press for nondiscriminatory application of state and federal law, or, when funds were available, through legal representation..$^{21}$

Recourse to diplomatic pressure was to be used only as a last resort. The day after the first set of instructions was sent to consuls, they were told to exhaust all legal procedures in each and every case which came to their attention. If necessary, federal courts were to be used as a device to check abuses committed by state and local judicial bodies. The circular of November 11 went on to say that if justice could not be obtained, the consul was to notify the Secretary of Foreign Relations as well as the Mexican Embassy in Washington, D.C. After each case was studied on its merits, a decision would then be made as to presentation of a formal protest to the American government. ${ }^{22}$

In order to avoid these procedures and cut down on the work load of consuls, the Secretary of Foreign Relations repeatedly cautioned his employees to admonish braceros to avoid confrontations with the police, courts, and 
local citizens. The use of Mexicans as strike breakers was particularly to be avoided. If workers took employment in a strike situation they risked a great dcal more than they could earn in the form of wages. American strikers became incensed, and this could only contribute to animosities between the two groups. Nor should braceros take part in labor stoppages against their employers. This course of action, the Secretary cautioned, inevitably led to many arrests and abuses by local police and additional difficulties with courts, especially in wartime. ${ }^{23}$

There were serious limitations on the implementation of this protective policy. Given the clandestine nature of much of the emigration, few consuls ever had an accurate idea of how many migrants were in their areas of jurisdiction. Many illegal entrants were fearful of making their presence a matter of public notice. Therefore, many instances of possible unfair treatment were never reported by braceros who, in any case, tended to distrust the whole of officialdom. One laborer who broke his leg in a packing plant in Kansas City typified the lack of trust migrants had in their home government's agents. The man's employer refused to pay damages for his loss of salary and pain and suffering. Rather than go to the local consul, the bracero followed the advice of his Mexican friends who told him he would be wasting his time to take that course of action. Other complaints were that consuls were only spies for Carranza's government; that they cared nothing for the migrants; that they were in the United States only "to enjoy the salary." 24

Other handicaps prevented consuls from fully protecting their conationals. These diplomatic representatives had as their primary charge the fomenting of commercial relations between the United States and Mexico: there was rarely enough time to give full attention to the problems of braceros. Financial resources were also severely limited. Rarely were funds available to pay for legal aid. Moreover, consular districts were so large and office staff so woefully inadequate that only small portions of any given area could be policed. There were never more than fifty-one consuls at a time when Mexican nationals in the United States numbered in the hundreds of thousands. ${ }^{25}$

Despite these inherent limitations, the Mexican diplomatic corps acted vigorously at times. Consuls were generally anxious to promote good relations with the United States under the "Carranza doctrine" of respecting the sovereignty of the laws of all nations. All braceros were urged repeatedly to register with their nearest consul so that he could ensure their protection by establishing nationality and providing a legal basis for consular intervention should it become necessary. Migrants were also exhorted to obey all laws of the host country in order to preclude possible difficulties with police and court officials. Zealous cousuls also helped illegal entrants by issuing them passports ex post facto to legitimize their status with the United States immigration authorities. The Department of Migration did not chastise consular officials who pursued this highly questionable course of action. ${ }^{26}$ 
Diplomatic representatives worked intensively to ensure the equal treatment of their fellow citizens. One major problem developed from the involvement of braceros in a wave of strikes sponsored by radical unions during the war. In Ray, Miami, and Globe, Arizona, for example, many of the 9,000 Mexican miners joined in a strike against local copper companies seeking higher pay and better working conditions. Reprisals rained down upon the Mexicans because their activities were considered treasonous by local civilian and military authorities. Strikers were jailed on the slightest pretext and continually harassed in other ways. The local consul, Yves Lelevier, was ordered by the Secretary of Foreign Relations not to interfere in any way with the course of the strike. He was, instead, to tell all Mexicans to obey all applicable laws, to help those who ran afoul of the law, and to make certain that the constitutional rights of each arrested Mexican were respected in conformity with local custom. ${ }^{27}$

In other cases which represent this category of diplomatic intervention, Ambassador Ygnacio Bonillas filed a formal note of protest with the United States Department of State concerning the courtroom practices of a muncipal judge in Oklahoma City, Oklahoma. The judge, with the support of the local newspaper, carried on a campaign to rid his area of people he termed "idle greasers." He ordered the city police to arrest all Mexicans encountered on local streets on a charge of vagrancy. Once the arrested persons were brought into court, they were given the choice of a term in jail or voluntary departure to Mexico. The Department of State promised to investigate the Ambassador's charges immediately to verify his allegations. If they proved to be true, the governor of Oklahoma would be asked to take steps to end the situation. Other consuls, acting in league with Bonillas, pressed state and federal authorities to use the full power of their offices to bring to justice Americans who had been arrested on charges of lynching Mexican workers. ${ }^{28}$

Consuls also became involved deeply in employer-labor disputes under this policy of aggressively promoting the rights of Mexican braceros abroad. Illustrative of this type of intervention was action by Consul General Teódulo Beltrán in May 1918 to protect braceros employed by the Spreckles Sugar Company in California sugar beet fields. According to Beltrán's report, Mexican migratory laborers were being treated worse than Porfirian peones. He found conditions of near-slavery, with open-ended hours, irregular pay, poor food, unfit housing, and armed men in the work camps to ensure submission. Beltrán filed formal complaints with workers' groups, state labor authorities, and the United States Department of Immigration. Then, once the Spreckles company faced imminent legal action and a barrage of bad publicity during a wartime period when Mexican labor was sorely needed, he began negotiating a new contract for the workers. An agreement was quickly concluded. Workers were to receive a wage of $\$ 2.25$ for a nine-hour day and 25 cents extra for every hour worked overtime. The company further promised better food and 
lodging, as well as the removal of its armed guards. Finally, the braceros were to enjoy complete personal freedom after work hours and on holidays. ${ }^{29}$

Many other activities of Mexican consuls related to employer disputes. For example, a road building firm in Hayden, Arizona, went bankrupt in the course of a construction project. This left a large number of Mexican nationals unpaid for work already completed; in the meantime, the owner of the company had disappeared along with most of his liquid assets. The consul in Tucson promptly sought to obtain some of the wages owed through a lien on the employer's property. In other cases, diplomatic representatives helped migrant workers and their families collect what was due them in the form of unemployment compensation or severance pay and death benefits. ${ }^{30}$

Perhaps the best example of the uses of Carranza's diplomatic agents to keep workers in the United States and protect them there was the manner in which the draft scare of 1917 was handled. Consuls went to work camps throughout the Southwest in the period from June to August and gave constant assurances that braceros would not be drafted into the armed services if they cooperated with their government's agents. Mexico was said to depend heavily on the money remitted home by the expatriates; thousands of men, women, and children relied on the money for their daily bread. If the workers returned, there was little for them to do at home anyway. Why give up the security of a good job and income because of the uncertainty of what might happen? Hand in hand with this campaign of persuasion in places of employment, Ambassador Bonillas worked out an agreement with representatives of the Department of State to avoid confusion and loss of workers in the future. Selective Service officials were to accept consular certificates of nationality and not insist on a notarized certificate of birth. The statement had to contain the bearer's name and current address, date of entry into the United States, and any actions taken to change his original citizenship. ${ }^{31}$

Throughout the course of the war, despite the actions described above, confrontations with local draft boards continued. Many, if not most, braceros neglected to comply with the wishes of the consular corps; some local draft boards continued to refuse to accept proffered consular documents of nationality. In Baltimore, Maryland, for example, when eleven workers were inducted after having failed to present proper proof of their place of birth, the local consul rushed to the Department of Justice and the Department of the Army and began a door-knocking, desk-pounding campaign of complaints. The army then discharged the men after they came up with satisfactory proof of citizenship which the consul had provided. In Jerome, Arizona, Consul Efren Ornelas accompanied six braceros through every stage of the induction process all the way to the training camp, protesting every step of the way. At the same time, Ambassador Bonillas pressed officials in Washington for action in the matter. After ten days of such pressure and protest the local board gave in 
and turned the men over to Ornelas. In the vast majority of those instances where consuls were careful in issuing proof of nationality, friction with local boards was kept to a minimum, and braceros were provided with either an additional reason to come to the United States or remain there without fear of being drafted. ${ }^{32}$

Despite some success, the Mexican government never solved the dilemma of emigration. Political leaders, particularly the feisty Carranza, wanted to stand up to the United States by allowing the exodus of only fully protected workers. The majority opinion that unregulated emigration was an evil which Mexico and Mexicans could ill afford gave added impetus for Carranza's government to attempt decisive action. The broader implication of emigration control was obvious: in a real sense it posed a test of political and revolutionary legitimacy. Mexican national interests and the welfare of Mexican citizens abroad had to be given priority - at the expense of the United States if necessary.

This ideal, however, had little chance of realization. The United States government extended almost no assistance to its Mexican counterpart in the management of the population flow. The wartime waivers, for example, were effected without prior consultation with Carranza's government; United States consular officers and labor recruiters surreptitiously urged defiance of Mexican law by braceros who wished to emigrate. Only when its own national interests were threatened in the draft scare of 1917 did the government in Washington allow its agents to pursue the common goal of keeping Mexicans in the United States in league with the Mexican consuls. The impossibility of any program of mutual, long-term cooperation dictated that Mexico alone had to regulate emigration and try to protect braceros or nothing would be done.

The disparate economic and political conditions in each nation further negated the ideal scenario hoped for by Mexican revolutionaries. Carranza could not afford the real and potential problems caused by large numbers of unemployed workers in an economy largely destroyed by civil war and inflation. The miserable have-nots were too much revolutionary tinder to be kept at home. The unemployed Mexican easily found work in the United States and sent home money which alleviated suffering and improved his native country's balance of trade position. In this very immediate sense the vigor of the United States' economy with its demand for braceros helped serve as a guarantor of governmental stability in Mexico. From the perspective of those who were in power, there was no valid reason to attempt a total halt to emigration.

Carranza and his bureaucrats largely failed in what they did try to do. Braceros placed little trust in their warnings. Driven by the imperious necessities of food and personal security, it is doubtful that any government could 
have succeeded in keeping workers at home. Once in the United States, the hundreds of thousands of Mexicans were left largely to their own devices as they coped with new experiences in a new land. Their home government lacked the funds and personnel to extend a full array of protective measures; they had little reason to look to that source for aid in any event. Individual consuls showed the clearest manifestation of zeal and humanitarianism for their fellow citizens. Their efforts to protect workers from employer excesses and from the errors of draft officials were surely one of the brightest spots in the United States for braceros and must be viewed as additional, albeit minor, inducements to emigration. When Carranza was ousted from power in May 1920 , some of the principles of the emigration policy of subsequent revolutionary governments had been thought through and articulated, but little had been put into effect. This minimal impact of the Mexican government upon labor expatriation helps to explain Mexico's unparalleled loss of workers in the 1920s. 


\section{5}

\section{Floodtide of the 1920s}

The number of emigrants increased greatly in this decade. In Mexico, violence motivated by religion, politics, and land redistribution schemes provided cause for flight for hundreds of thousands of workers. The quality of life was further worsened by food shortages and inadequate wages which resulted from inflationary conditions during the preceeding decade. Testimonies left by braceros clearly evince the desires for personal safety and self-betterment as the two major, continuing causes of exodus. In the United States, the booming economy of the 1920s gave rise to a growing demand for Mexican laborers. New laws permanently reduced the immigration of unskilled workers from Europe and gave rise to an increased need for braceros at points far from the border. Smugglers and recruiting firms helped to serve these new needs and were partially responsible for the growth of the Mexican immigrant community. Higher wages induced migrants to travel to points far from the border. There also appeared more sophisticated devices and procedures to ensure permanent settlement and an ample supply of workers. By the end of the decade the number of Mexicans in the United States had reached unparalleled proportions.

Historians customarily date the military phase of the Revolution in Mexico from 1910 to 1920 . For the rural campesino and peon classes in many areas, however, violence continued to be an almost everyday occurrence after 1920. Indeed, our sources reveal that to live in rural Mexico was to experience at times life in a slaughterhouse. Violence and death continued to come from armed rebellion. Perhaps the best known military action of this period is the Cristero rebellion, in evidence in every state of the central plateau and especially in Jalisco. Savage attacks on both Catholics and their enemies were 
commonplace and resulted in the loss of many lives, often for senseless reasons. The town of San José de Gracia in Michoacán suffered a fate similar to many other settlements in central Mexico. Predominantly mestizo, the town's inhabitants had suffered indirectly from the Revolution because of the difficulties in marketing their cattle and foodstuffs. Cataclysmic disaster did not strike until October 1927 when federal army General Juan B. Izaguirre, frustrated at his troops' inability to encounter and defeat Cristero guerrillas, ordered the town burned to the ground. Thousands of head of cattle were stolen and the villagers were driven off. "It was a place of roofless walls, rubble, ashes, and charcoal, with green grass sprouting in the streets and on garden walls" in the words of one local historian. This disaster, coupled with the effects of the earlier trade disruptions, made San José de Garcia a fertile source of emigration throughout the 1920s. The area lost 15 percent of its population by 1930 , some of it to the United States. Many workers fled from other areas to avoid taking sides in the conflict or risking their safety through attemps to remain neutral at home. Many other minor, but no less deadly, disturbances also plagued the countryside. For every person killed, many more fled their homeland in order to ensure their personal safety. ${ }^{1}$

The agrarian and land distribution programs of revolutionary leaders also led to bloodshed. Once Obregón became president in 1920 he started a program of distributing ejidos to rural inhabitants who petitioned for them. From 1920 to 1929 Obregón and his successor, Plutarco Calles, gave out almost $4,500,000$ acres of land in ejidal grants to 588,692 people. The resulting change in land tenure patterns was disastrous for the tranquillity of rural areas. Some hacienda owners, now back on their properties after the violent shocks of the previous decade, organized "white guards," small private armies, to fight peasants who had obtained ejidal grants or had asked the government for them. State and local governments often aided landowners in areas where revolutionary sentiment was not strong. The resulting battles were savage as scores of men, women, and children were murdered. Houses were burned, animals killed, and wells poisoned. The carnage and destruction became so intense that on many occasions the federal army had to intervene to bring order. ${ }^{2}$

Even the hope of ejidal grants provided an element of unrest before the government had become a party in the matter. Many landless peasants had expectations of receiving land from federal authorities. In anticipation of a favorable decision, workers took over by force parcels of land, hoping their claim would be reinforced by actual possession. In this manner, many farmers were evicted from their properties and had no choice except emigration from the countryside. ${ }^{3}$

Violence also frequently accompanied disputes unrelated to changes in land tenure. There were few men who did not go about armed because of the importation of millions of small arms and rifles during the Revolution. Local political leaders armed their followers, and the federal governments of the 
1920s gave guns and ammunition to many campesinos in an attempt to counterbalance the power of the military. In other instances, agents of the federal government armed members of the hacienda's private armies in order to forestall local anarchy or to ensure the on-going functioning of agricultural lands. The inevitable result of these situations was that bloodshed regularly accompanied almost every public or private dispute. ${ }^{4}$

Rural instability meant that domestic agriculture was incapable of growing enough food to sustain the national population. Throughout the decade critical food shortages continued to plague the heavily populated central plateau states as they had since the days of Porfirio Diaz. The governments of Obregón, Calles, and Portes Gil expended millions of pesos in an attempt to import enough corn and beans to keep the population at a near-subsistence level of food consumption. The total volume of agricultural production in the 1920s never exceeded in any given year the amount of food grown in 1910, but from 1910 to 1930 Mexico's total population, despite emigration and losses from revolutionary violence, grew from $15,160,000$ to 16,553,000. As had been the horrendous case in late Porfirian times, the third decade of the twentieth century saw no respite from widespread starvation in the countryside. One immediate response to these conditions was that campesinos, armed and often unchecked by any strong governmental institutions, seized their neighbor's crops and consumed them in the course of a year. During the next growing season fewer people would bother to plant their lands for fear of being robbed again. For many, only the United States could ensure an ample supply of food. ${ }^{5}$

Nor did the government's program of distributing ejidal lands offer hope for increasing the supply of food. Apparently not wishing to tamper with an already precariously low volume of food production, Presidents Obregón, Calles, and Portes Gil granted ejido lands which were generally of poor quality, and, given the sparse private and public resources that were available to improve these lands, the new ejidos were negligible factors in the amounts of surplus food they provided. To be sure, in early 1926 Calles founded the Irrigation and Agricultural Development Bank to aid the newly created ejidos, but none of the intended results took place because of shortages of funds and wide-scale lack of probity on the part of bank employees. Ejidal grants caused a sharp decline in food production on land previously held as private property. Many owners of private plots, large and small, refused to plant their holdings for fear the land would not be theirs at harvest time. ${ }^{6}$

Insufficient wages for those lucky enough to have a job in the 1920 s continued to be a causal factor of emigration. Money paid to peones and campesinos had increased in a few areas but did not keep pace with rising prices brought about by food shortages and population increases. According to the office of the Secretary of Industry, Commerce, and Work, prices had generally risen 300 percent faster than wages. There had been, the report concluded, no revolutionary benefits in rural areas. Campesinos and peones 
in the vast majority of instances spent all their disposable income for a subsistence diet of corn and beans, when they were able to find these staples. In many states of the central plateau region wages were the same as in 1910 and earlier. The situation found by Ernest Gruening was not atypical:

In [the states of] Guanajuato, México and Querétaro I found peons' wages as low as 12 centavos a day, and in two instances of women doing men's work around the private gardens-six centavos ( $\$ 0.03$ cents, U.S. cy.). To this must be added a daily ration of about 6 centavos worth of com. In 1923 I discovered in fourteen haciendas no instance of wage increases or decreases within the memory of the oldest workers. ${ }^{7}$

Nor did industry in Mexico offer a refuge for those who sought to flee from rural conditions. A government study carried out in 1927 showed that industrial wages averaged 1.29 to 1.76 pesos a day for a variety of jobs in 700 urban areas. Yet in order to maintain a "minimum of comfort" standard of living as defined by Mexican economists the average city family had to receive five pesos per day. Structural imbalances in the economy added increased unemployment to depressed wages. Manufacturing productivity stagnated until the late 1920s because of the violent shocks of the first decade of the Revolution, continuing labor strife, and the lack of investment capital. Per capita agricultural production fell 18 percent from 1907 to 1929; in absolute terms, Mexico grew 40 percent less corn and 31 percent less beans in 1929 than had been produced in 1907 . The heavily populated central states suffered proportionately larger declines and thus continued to provide the largest share of emigrants to the United States. Economic recovery did not begin until the very eve of the Great Depression. This long-awaited growth did little during the decade for the more than $1,000,000$ people added to the Mexican population from 1921 to $1930 .^{8}$

Those who left Mexico to escape these harsh conditions brought about by the Revolution have expressed their fears and hopes, past and future, in corridos, interviews, and hundreds of letters to political leaders. The fratricidal conflicts brought about by religion and politics caused intense despair in the hearts and minds of rural dwellers. As Merle Simmons has observed in his classic study of Mexican folk songs, "the ever-rising demand for peace with its corollaries of justice and an opportunity to work [took] precedence over all other needs."

We must understand that the war is among brothers; although we are of different political beliefs, we are all Mexicans....

Let's try to end the war. ${ }^{9}$ 
In the words of another folk song, "we were already suffering incredibly bad conditions when this new revolt crushed us in a horrible manner." 10

The letters of expatriates to Mexican political leaders show an overwhelming desire for personal safety as an important cause of emigration. Gonzalo González, for example, wrote to President Obregón in March 1921 and stated that the peace, personal safety, and individual guarantees found in Texas made his life worth living. If Mexico was ever able to attain these same conditions, then he would return home. The family of Mónico Escalante fled to the United States in 1927 because of a situation engendered by uncontrolled violence. The family owned a small piece of agricultural property near a newly created ejido. Neighboring campesinos used the general agitation for agrarian reform to take control of as much land as they could in anticipation of a grant from the Calles government. The Escalantes' house was burned down one night, and they feared that this act of arson was but a prelude to acts of assassination. Another worker who fled across the border gave his reasons more succinctly: "I did not want to get shot down from one day to the next." 11

Many rural workers placed the blame for their poverty-stricken lot on the hacienda. The miserable working conditions before and after the Revolution and the turmoil and violence in the countryside in the 1920s evoked a strong feeling of hatred and disgust for the land-owning class. As one peon saw his plight,

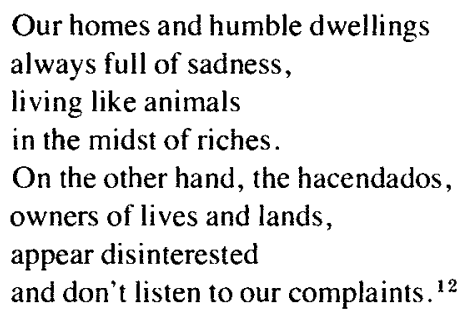

A defender of the emigrants explained the great disparities in life styles on the hacienda in more graphic terms:

But those who are to blame [for emigration]

are those unkind employers

who don't give their people

enough to buy a jacket.

I'm not criticizing the country,

but I certainly tell you

that many of the laborers

go naked to their navels. 
The rich go in automobiles, riding a good horse and a good saddle, while the poor peones go about half naked.

The peon is always burdened, is treated with cruelty; the rich would like to see his head where they see his feet.

They treat him like a slave, not always a useful servant who pours out for the rich his last drop of sweat.

Here one works a year without earning enough for a shirt; the poor man suffers always and the rich man laughs and laughs. ${ }^{13}$

Grinding poverty thus provided an extremely strong inducement to emigration. Those forced to leave their native land often did so with much sadness. "An Emigrant's Farewell', ('Despedida de un Norteño') poignantly sums up these misgivings of leaving all that is familiar to the worker:

Goodbye, my beloved country, now I am going away; I go to the United States, where I intend to work.

Goodbye my beloved mother, the Virgin of Guadalupe; goodbye, my beloved land, my Mexican Republic.

At last I'm going, I bear you in my heart; my Mother Guadalupe, . give me your benediction.

I go sad and heavy-hearted to suffer and endure; my Mother Guadalupe, grant my safe return. 
Mexico is my homeland, where I was born a Mexican; give me the benediction of your powerful hand.

I go to the United States to seek to earn a living. Goodbye, my beloved land; $I$ bear you in my heart.

For I am not to blame that I leave my country thus; the fault is that of poverty, which keeps us all in want ....

Goodbye, fair Guanajuato, the state where I was born; I'm going to the United States far, far from you ....

And so I take my leave of my country, Mexico. I have reached Ciudad Juárez. Oh, Virgin of Guadalupe! ${ }^{14}$

Despite the difficulties inherent in leaving Mexico, braceros gave many other compelling reasons which sent them northward. Ignacio Palacios wrote Portes Gil from Toledo, Ohio, "exactly two years ago today I and my two sons abandoned the Fatherland and came to this country in search of work ... because work could not be found [in Mexico] and there were no clothes to wear or food to eat." Another emigrant, Abraham Lima, wrote to President Calles concerning his situation. Lima was seventy-five years old and worked in Laredo, Texas, where he hoped to obtain the capital needed to set up a barbershop in his hometown of Monterrey. Attacks on Catholics also drove many across the border. Arandas, Jalisco, for example, lost 1,300 of its inhabitants who had fled for fear of reprisals from federal army groups in their area. As one of the emigrants said, "we all were in fear." Other Catholics who had taken up arms during the Cristero revolt similarly fled to the safety of the United States after the fighting because of the expectation of vicious reprisals upon themselves and members of their families. ${ }^{15}$

Other laborers immigrated into the United States for a wide variety of reasons. For some, a trip across the border was a great adventure, a chance to see a strange new people and culture. Often these adventurers worked and traveled in dozens of states, riding the rails to a new location as soon as the 
newness of their old habitat wore off. Some emigrated in order to join family members already in the United States. Often a husband or younger brother would go alone to seek employment and adquate housing for the rest of the family. Once this was accomplished and a few dollars could be saved to purchase railroad tickets, they would be sent for from Mexico. ${ }^{16}$

Other workers went to the United States so they could be in contact with what they thought to be a superior culture. Many people in this group looked down on their fellow countrymen as lowly Indians who lacked all knowledge of modern living. They were seen as uneducated and frequently in trouble with the police and the court systems. Americans, on the other hand, were gente decente who lived properly. "If our country could only be this way," so one migrant worker expressed this sentiment when he compared the two nations; another, in a similar vein, thought his fellow Mexicans were content only to "loaf around and drink" in Mexico instead of coming to the United States to improve their life-styles. Jesús Mendizábel looked down on his native country because of its Catholicism. In his own words, "my parents taught me the Catholic religion so that I am a Catholic, but I am not a fanatic nor have I ever been. I think that we are so backward in Mexico because the people only think about the Church and not about work." 17

The general popular view of the United States, however, was not a favorable one. Indeed, it is very difficult to encounter materials which praise the new land of the emigrants. Letters and corridos, with almost numbing regularity, forcefully point out the real and potential dangers which awaited would-be emigrants. The most pervasive concern of popular literature was the danger of de-Mexicanization. Witness the disparaging remarks about those who adopt American cultural traits:

You go around showing off

in a big automobile....

When you learn a little American

and dress up like dudes,

and go to the dance.

But he who denies his race

is the most miserable creature.

There is nothing in the world

so vile as he,

the mean figure of the renegade ....

A good Mexican

never disowns the dear fatherland

of his own affections. ${ }^{18}$

Another corrido explains how one emigrant steels himself for the expected assault on his nationality: 
I'll tell the Americans

how beautiful my Mexico is;

where there is work and

a lucky people live happily.

I'll tell them the truth.

That Mexico is beautiful and

is the land of liberty.

We must use our beautiful music

and our virile songs to speak up

for our race. ${ }^{19}$

Many expatriates protested their loyalty to Mexico by offering to defend her should war come with the United States. At the height of the Cristero conflict, for example, Macedonio Navarro led a group of braceros who wrote to Calles and informed him of bitter attacks in the American press which scored the President's "Bolshevik" tactics against organized religion. If this propaganda campaign continued in the United States and led to war between the two nations the workers would return to the fatherland to protect it against foreign invaders. Another letter, written by a worker to Obregón in July 1921, stated that if another war with the United States should occur he was "as always, ready to lend [his] insignificant services for the well-being, honor, and liberty of his nation." 20

Frequent complaints were also voiced about officials in the United States. The song entitled "Life, Trial and Death of Aurelio Pompa," for example, details the unfair trial and execution of an emigrant in California. On the eve of his execution Pompa tells his fellow countrymen with his song,

Tell my race not to come here, for here they will suffer; there is no pity here.

The jailor asked him:

"Are you Spanish?" and he answered, "I am a Mexican and proud of being so although they deny me a pardon."

This is the story of a compatriot who four years ago came there and through misfortune on the same day died in a dreadful way in a prison. ${ }^{21}$ 
Racial prejudice and attendant patterns of discrimination encountered in the United States were also quickly passed along the "grapevine." Gilberto Loyo signaled the hopes and fears provided by the United States for many dark-skinned Mexicans. As a young man Loyo was very impressed by the tangible objects such as shoes and watches which were brought back by migrants to their home villages. It occurred to him, however, that most repatriates were dark complected, and that only the lighter-skinned braceros remained in the United States for extended periods of time. He spoke to many returnees and, confirming his suspicions, was told that the prietos (the dark ones) often had problems because of their skin coloring. He was advised to stay home because of his dark skin. Those who did emigrate reported instances of unpleasant memory. Wenceslao Iglesias, a bracero of white skin and light eyes, and several compatriots were sent by train to a new job site in Kansas. They boarded the train and started to walk through a passenger car to get to their seats. Some Americans "began to rage against us saying that they didn't want to go in the same car with colored people." Other Mexicans were regularly excluded from public swimming pools and dance halls. Others were forced to eat in the "For Colored People" sections of restaurants. This pattern of behavior was deeply resented by immigrants of all classes and colors. ${ }^{22}$

Why, then, did emigration continue unabated during the decade? Many of the fears concerning the United States, of course, turned out to be untrue. Not all workers encountered the dangers they were urged to avoid, and their experiences did much to negate unfavorable reports. Another factor was the non-emigration of many dark-skinned workers such as Loyo. The forces which pushed Mexicans across the border were, in any event, impelling enough to relegate to unimportance possible dangers that emigrants might face. At home, the insecurity, lack of food, and violence were everday, real possibilities; what might have happened to them in the United States could be dealt with when and if it happened. The corrido "Conversation Between Two Ranchers" neatly sums up the advantages of leaving Mexico and going to the United States. The returned worker, although he later recants, defends and boasts of his journey to the north to his friend who remained home in the following terms:

If you could only see how nice

the United States is;

that is why the Mexicans

are crazy about it.

You can't imagine how it is

to live like a lawyer,

with a good shirt, good suit, good overcoat and shoes. 
Your watch on its chain

and your scarf-pin in your tie

and your pockets always filled

with plenty of silver.

Depression is unknown

there in a foreign land;

all the workingmen

always earns good pay ....

Then I went to St. Louis, to Kansas and Santa Fé;

in Washington, how swell!

I got tired of so much pleasure.

I knew Los Angeles

foreward and backward;

I got thick with the gringos,

as I know how to talk English.

Come, man, unbandage your eyes;

don't let yourself be exploited

by men who claim to be wise

and who study only to rob.

Look how splendid the north is-

lots of electricity;

machines for everything, an enormous number of them.

With compressed air they raise up into space not only rails and ties but even whole palaces.

The truth is those big feet [i.e., Americans] are considered very smart; they are not like this country, which is plagued with stupid people.

Over there they have protection, intellegence, and wealth; that is why I sigh for it, and yearn for a foreign land. 
Here for twenty-five cents one works from sun to sun; there is nothing to eat but tortillas and beans.

I grant that Mexico is very pretty, but it's down and out; one works day and night and never ceases to be a pelado [penniless Indian]. ${ }^{23}$

The Annual Reports of the Commissioner General of Immigration for the 1920 s provide a good profile of the migrant laborers who sought economic betterment for themselves in the United States. While no comparable information is available for wetbacks, they probably evinced much the same general characteristics. Migrants were young; in the prime of their lives. In any given year, those forty-five years of age or older did not exceed 7 percent of the total number of entrants; those fourteen years of age or younger comprised around 20 percent of the group. Those in the fifteen to forty-four age bracket were most willing - and most able-to trek northward and face the inherent problems of finding work and settling in a new, strange country. Once this initial step was accomplished, other family members, usually a wife and children, were sent for ${ }^{24}$

The Annual Reports further point to young males as the "advance men" by showing that 65 to 70 percent of the entrants throughout the 1920 s were men. It is likely that many of these individuals who entered the United States legally had their families join them later without passing through the immigration recording stations on the border. In this way a substantial savings resulted as the remaining members of the family did not have to pay the head tax and other entry fees. In cases where heads of households did not send for relatives to join them there were three, four, or more individuals in Mexico who depended on them for money remittances. Manuel Gamio, in a study of postal money orders sent to Mexico in the month of July 1926, found that approximately 12,000 braceros sent almost $\$ 300,000$ to their relatives. For the entire decade over $\$ 58,000,000$ was remitted to Mexico through the medium of postal money orders alone. Other forms of notes, drafts, and cash accounted for additional millions of dollars. ${ }^{25}$

Unskilled workers continued to constitute the vast majority of emigrants throughout the 1920s as was true in previous decades. Agricultural and household laborers in every year made up 80 to 92 percent of those legally admitted. The remainder, classified as skilled or semi-skilled by authorities in the United States, were craftsmen, clerks, and farm managers who were usually employed by firms with large numbers of unskilled braceros. Most of these people were probably bilingual to some degree and served as middlemen 
for their American employers. While the percentage of people in these latter categories rose slightly in the late 1920 s, they never constituted more than a negligible part of the total number of emigrants.

Strong attractions continued in the United States during the booming 1920s. The Immigration Acts of 1921 and 1924 were of primary importance during the decade. The first was a temporary, emergency measure to ensure that millions of Europeans who suffered the effects of World War I would not flood into the United States. This was accomplished by imposing a 3 percent limitation on immigration from any European country based on the number of each nationality in the United States as of the federal census of 1910. During the first fiscal year of the law's application, 1921 to 1922, the number of immigrants from Europe, most of them unskilled laborers, dropped to 309,556 , a decrease of almost 500,000 from the previous fiscal year. ${ }^{26}$

One of the primary reasons for the passage of the laws of 1921 and 1924 was a strong nativist feeling that foreigners presented a threat to American civilization. President Coolidge signaled this belief when he called for immigration "limited to our capacity to absorb them into the ranks of good citizenship." The underlying premise of this statement was that certain ethnic groups were inherently incapable of understanding and acting within the framework of Anglo-Saxon democracy and culture in a beneficial manner. For all intents and purposes the law of 1924 ended the immigration of large numbers of cheap, unskilled workers from European countries such as Italy, Poland, Greece, and Romania. The new legislation set a quota of 2 percent for each nationality group based on the count of the census of 1890 . The key point was the base year. It was not until after that date that the "new" immigrants from southern and eastern Europe had begun to pour into the United States. Moreover, all of the quotas of individual countries were not to exceed 150,000 people annually. The result of this law was that, in the words of its many nativist advocates, the "correct racial preponderance [of] the basic strain of northern and western European strains was maintained." "After three centuries of free immigration America all but completely shut her doors to newcomers.",27

This was not true for Mexicans. Indeed, the abrupt end of other sources of labor to fuel the economic activities of factories, fields, and mines intensified the need for braceros. As a gesture of goodwill and economic self-interest, Mexico and other nations of the New World had been excluded from the provisions of the new legislation. Certain entry requirements were spelled out for braceros in an attempt to cut down on the number of illegal border crossings. Immigration restrictionists placed a great deal of hope on the $\$ 18.00$ levied by the new law in entry fees as most incoming Mexicans did not have that amount of money. There was a fee of $\$ 10.00$ in order to obtain a visa from an American consul, and a head tax of $\$ 8.00$ which had to be paid upon crossing the border. Braceros also had to pass a literacy test, prove they 
were not paupers, and undergo a medical examination to show their physical fitness. ${ }^{28}$

The law of 1924 also established the Border Patrol to enforce the law's provisions. Yet the Patrol was severely limited in its effectiveness. As late as 1928 it had only 747 men to police the vast international boundaries (Canadian and Mexican) under its jurisdiction. Nor did members of the organization ever consider the apprehension of would-be illegal Mexican immigrants to be their primary function until the very end of the decade: most of their efforts went toward the enforcement of customs regulations and prohibition laws. ${ }^{29}$

The expense, delays, and exclusionary clauses imposed by the law of 1924 combined with the lack of border patrol to make illegal entry easy. A large number of professional smugglers called coyotes arose. The most common method of illegal entry was found in small Mexican towns along the border which had lively night spots such as gambling halls and saloons patronized by American citizens. Late at night the coyotes guided small groups of braceros across the border when parties of American residents returned to their country. Wetbacks would usually slip across the line unnoticed with the United States citizens. Manuel Gamio reported that one small town near Ciudad Juárez daily received several busloads of workers who then crossed the border on foot.

Coyotes also employed more sophisticated methods to smuggle wetbacks into the United States. Usually they hung around street corners near rooming houses or employment agencies on the lookout for laborers too impatient with the laws' formalities or unable to meet their requirements. The smuggler approached likely prospects and suggested that for a fee of $\$ 5.00$ or $\$ 10.00$ the worker could be in the United States that night after a short car or boat ride. Other smugglers for a fee of $\$ 2.00$ or so "rented" entry permits to individuals who would mail back the papers once they had crossed the border. Through the use of signals and the maintenance of "safe" stations for the laborers, it was possible for gangs of smugglers to operate extensively and quite profitably along the length of the entire border. ${ }^{30}$

Gamio correctly realized the dynamic force behind this huge illegal population movement to the United States when he wrote,

This immigration developed rapidly [beginning around 1900] and could soon be numbered by the hundreds of thousands. As a result, a large part of the commercial and industrial activity in the frontier cities and states developed by using Mexican labor, and it would now [1926 to 1927] be impossible or exceedingly difficult to continue such enterprises without it. This fact has been proclaimed constantly by employers .... The propinquity of the two countries and the enormous extent of the boundary make it absolutely impossible to prevent immigration .... ${ }^{31}$ 
At places near and far from the border unmechanized agriculture continued to provide seasonal employment for the bulk of Mexican workers in the United States. Rural areas continued to decline in population as native laborers left in search of higher-paying employment in industrial pursuits. About $6,000,000$ individuals left farms for the life of the cities during this decade. So massive was this population outflow that by 1930 United States citizens engaged in farm work numbered about the same as, or slightly less than, those who had followed agricultural pursuits in 1900, despite the millions of additional acres put to farm use. This phenomenon worsened earlier acute shortages of labor in areas of sugar beet, cotton, and vegetable production. Yet the output of these industries continued to grow during this period and produced over $\$ 7,000,000,000$ worth of marketable goods anually. Mexican labor was sorely needed to till and harvest the millions of acres: a sufficient supply of labor was simply unavailable from any other source..$^{32}$

Similar labor shortages also meant that Mexican muscle remained indispensable for many other economic activities. Braceros were the "backbone" of the mining labor force according to Howard D. Smith, Chairman of the American Mining Congress' immigration committee, in his testimony before a Senate group in 1928. He estimated that 60 percent of the 17,000-man work force were Mexicans. A spokesman for the Association of Railway Executives told of his industry's even heavier reliance on continung immigration from Mexico: some railroads had a work force comprised of as much as 90 percent braceros; not one company which belonged to the association had fewer than 50 percent Mexican immigrants in their laboring force. ${ }^{33}$

Labor recruiting agencies well in the interior of the United States sprang up to service the needs of industry and agriculture deprived of European workers. Chicago, because of its central position in the midwestern railroad system, became the focal point of imported Mexican labor soon after 1921. Labor recruiters obtained workers from the border in several ways. The most common device was to form a partnership with a similar firm in San Antonio, Texas, the nexus of southwestern railroads. The northern firm paid a fee to the agency in San Antonio at a stipulated rate per head. Once the workers arrived in Chicago they were apportioned to private firms for a fee. In almost all instances railroad transportation costs were paid for by the ultimate employer who then deducted the money from his workers' paychecks. Another way of obtaining braceros was through the agency's cooperation with coyotes who operated along the border. The smugglers placed their human cargo on a train bound for Chicago; after the arrival of the workers the coyote received a check for each worker who had presented himself.

It was also common for agencies to "raid" employers and induce braceros to work elsewhere for higher wages. This occurred with increasing frequency to railroad workers. It remained so easy for the rail companies to replenish their labor supply from points near the border that this practice was 
not resented, and, at times, even encouraged if it meant that farmers and industrialists obtained braceros to handle crops and products that would be carried by rail. By the late 1920 s packing and steel plants in the Chicago area had come to depend largely on the railroads for their supply of new workers. In 1928 a survey showed that 159 of 401 Mexicans in Chicago's Wisconsin Steel Works listed railroad employment as their last previous work. Almost 50 percent of braceros employed in packing houses of Armour \& Company and Swift \& Company reported a similar shift in employment. Information from only one year has come to light regarding the scope of labor inflow which resulted from labor agency efforts. In 1927 the heads of sixteen such businesses stated that they had placed 75,400 braceros in jobs in the Chicago area. ${ }^{34}$

The timely recruitment of Mexican workers became an essential component of the success of the sugar beet industry in the midwestern and western sections of the United States. Sugar beet harvests were bulky and highly perishable; time was of the essence in getting the harvest to a refinery before its sugar content lessened. These circumstances brought about a highly interdependent relationship between farmers and refiners. The latter usually advanced the large amounts of money needed to plant and grow the crops and purchased the entire harvest while it was still in the ground. In order to expedite all the processes involved, refinery personnel, through labor agents located in border cities, brought to the local area the necessary numbers of Mexican workers. The company determined the wage to be paid by the farmer to his employees. The continuing importation of large numbers of braceros thus became part and parcel of sugar beet farming and refining throughout the United States. ${ }^{35}$

Employers in other agricultural pursuits employed similar methods to attract bracero labor. The most common device used was the creation of a voluntary taxing association. Growers contributed to a general fund an amount of money which depended on the number of acres they had under cultivation. This usually averaged $\$ 1.00$ per acre. Personnnel of the group then remitted this money to recruiting agencies along the border when this self-assessed tax equaled the sum needed. Other employers who sought workers simply placed want ads in Spanish-language newspapers in the Southwest and found that many more applicants than were needed usually applied for work. ${ }^{36}$

Along with these inducements, private companies mounted extensive campaigns to keep Mexican migrant labor in their areas. The sugar beet industry, for example, almost overnight became the exclusive domain of braceros after the laws of 1921 and 1924 all but ended the immigration of Slavic workers. In all western states, and especially in Colorado, Montana, Wyoming, and Nebraska, sugar beet companies purposefully encouraged the 
emergence of a permanent, resident Mexican laboring class in order to ensure quick access to nearby labor pools. The companies provided at minimal or no cost building materials for homes on land they owned. Thousands of Mexican families settled in areas of sugar beet production and refining. Similar influxes of braceros took place as a result of farmer and industrialist promises in other western and midwestern areas. In Chicago, for example, one immediate consequence of the Immigration Act of 1921 was a campaign to draw thousands of Mexican workers and their families so as to provide permanent replacements for the Europeans who had previously swelled the ranks of low-paid jobs. Industry in Pennsylvania also brought in many Mexican workers from the border region. ${ }^{37}$

Rural employers developed other processes to create a stable source of bracero labor. In California local and county farmers' groups formed a statewide organization to coordinate and anticipate times of peak demand for imported laborers. This system of labor allotment meant that many Mexicans never had to leave the state because of the availability of year-round work for them, yet at the same time they could not settle permanently and become landowners. Other less ambitious but equally efficient schemes saw employers send their workers to nearby towns in the winter in hopes they would obtain work in construction projects or indoor work ${ }^{38}$

An untold number of migrants went to the interior of the United States and permanently settled there of their own volition. A pivotal reason for this internal migration was the wage differential between border areas and points further inland. Just as wages drew many Mexicans across the border, they also induced them to leave the Southwest. Within one hundred miles of the border agricultural wages rarely exceeded $\$ 1.00$ a day. Pay for ranch work, usually without board, was $\$ 1.25$ to $\$ 2.00$ a day, while other types of work such as clerking, mining, and factory work ranged up to $\$ 3.00$ a day maximum. ${ }^{39}$ On the other hand, available wages far from the border were markedly higher and reflected the relative scarcity of workers willing and able to perform arduous unskilled work. One should remember that the value of these wages compared exceedingly well to that in Mexico. The cost of living in the United States was lower than that of Mexico, and wages south of the border were only a small fraction of the average expatriate's earnings. Gamio estimated that even skilled workers in Mexico earned only about one-third of what was needed for the normal necessities of life. The vast majority of Mexican laborers received perhaps one-eighth of what they and their families needed. This situation, Gamio concluded, ensured the worker only "insufficient food, inadequate clothing, unhealthful homes, and deficient medical attention." 40 In marked contrast to conditions in the braceros' homeland, Table 5.1 demonstrates the inducement to migration provided by wages in the interior regions of the United States: 


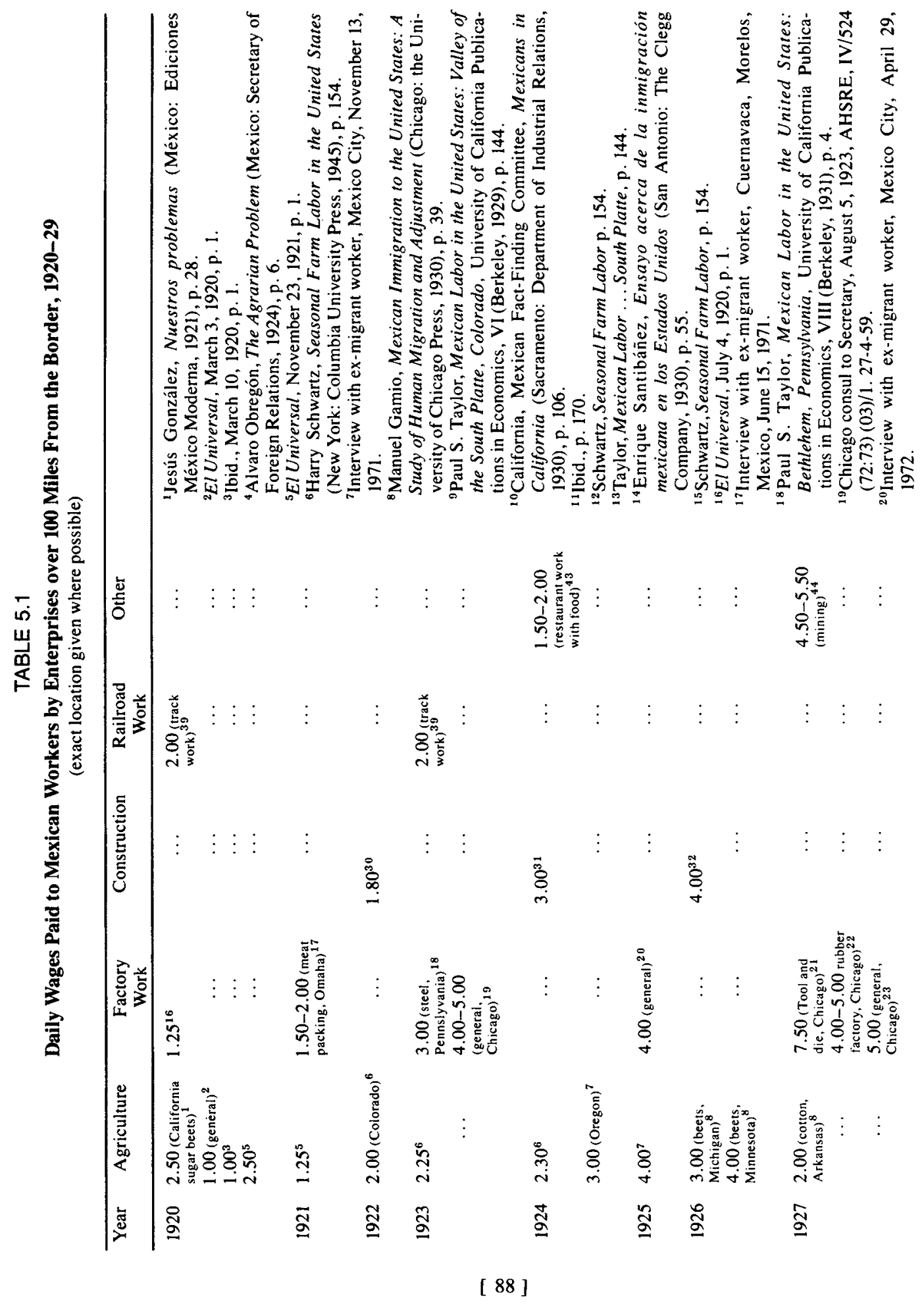




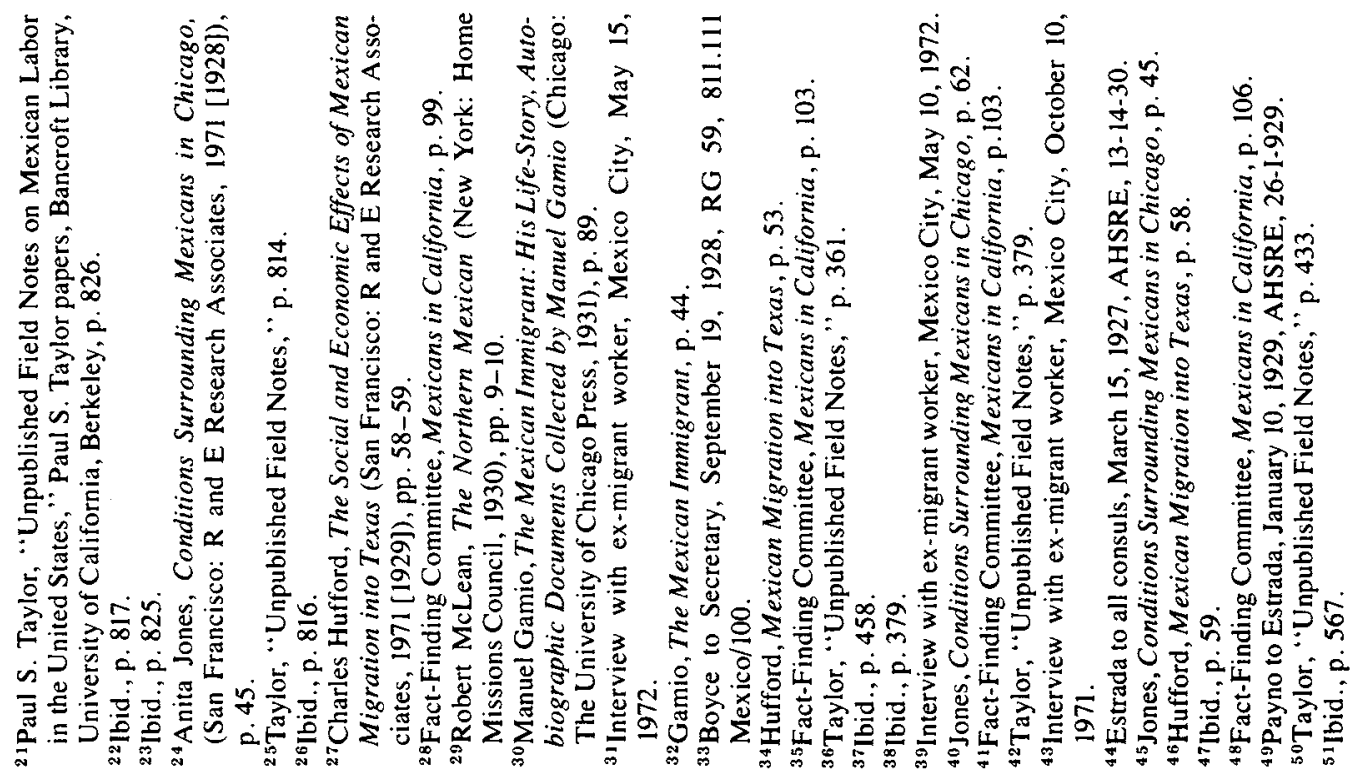

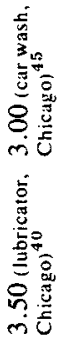

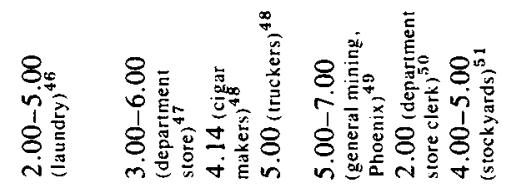

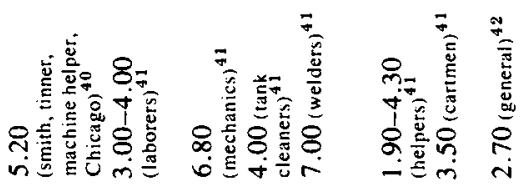

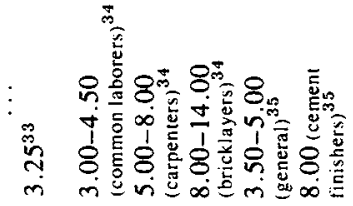

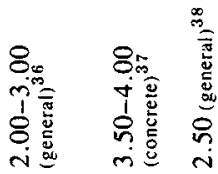

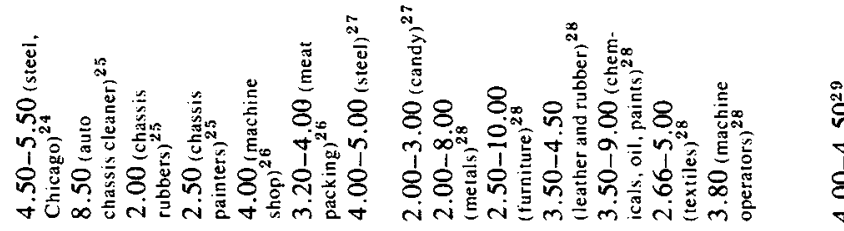

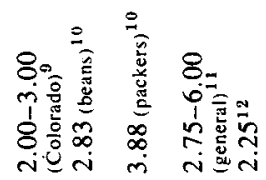

ఏ్

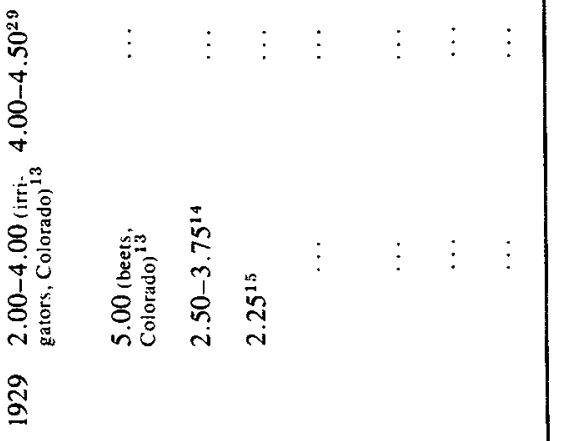


In summary, wages continued to remain a powerful inducement to emigration in the 1920s. In comparing money earned in the United States with wages available to braceros in Mexico, Gamio concluded that Mexican workers earned, on the whole, six times the amount they could earn in their native land. They earned not only an amount sufficient "to satisfy the elemental requirements for minimum comfort, a condition not yet attained in Mexico, but ... [to] spend money for education, recreation, and so on." 41

Public and private charity services available in the United States provided another cause of emigration as well as a motivating force to remain near job markets. Needless to say, such resources and services to meet the exigencies of life were not available in Mexico. In the United States, the vigor of the economy, coupled with a profound desire to alleviate conditions of misery whenever possible, had given rise to a multiplicity of agencies which were capable of providing social assistance in the forms of money, food, housing, and medical care for those unable to purchase such things with their own resources. Since many braceros were employed only in seasonal agricultural work, they faced the bleak prospect of long, hard winters with little chance of obtaining work in their usual occupations. For this reason many migrants, often at the urging of their employers who were anxious to have a labor force nearby for the next spring planting, flocked to the cities at the end of the summer season with the expectation of receiving a dole from municipal or county governments. As one migrant worker recognized when he spoke to missionary Robert McLean, "If you are out of work in this country, somebody will feed you; if you are out of work in Mexico, nobody cares." With this view of charitable services as a cushion during times of slack work, braceros and their dependents quickly came to comprise a disproportionate number of those receiving social assistance in the 1920s. In Chicago and El Paso, for example, one-half of the work of relief workers and agencies was with Mexican migrants; in Los Angeles by the latter part of the decade aid to braceros amounted to one-third of the total money expended for charity services. ${ }^{42}$

Louis Blaylock, mayor of Dallas, Texas, took decisive measures in the winter of 1928 to use charitable resources to keep braceros in his city's area. Several hundred Mexican migrant workers went to Dallas after the completion of the harvest season, and by January 1928 they had exhausted their resources. County welfare authorities aided the indigents but soon ran out of funds. At that point Blaylock stepped in to help through an appeal to the general public. The Good Sinners' Club set up a soup kitchen, and other private parties donated money. By the middle of February, with the planting season only about a month away, public and private charity efforts had ensured a dependable source of laborers for growers in the area adjacent to the city. ${ }^{43}$

Religious bodies also set up elaborate programs of social aid in attempts to gain converts or to keep coreligionists within the fold. Protestant mis- 
sionaries offered money payments, housing, and employment aid as drawing cards for potential converts to their various denominations. The Catholic Church, not to be outdone by any other religious group, also extended aid when it could to migrant laborers in an attempt to show it also had a social conscience when it came to its poor parishioners. ${ }^{44}$

Salvador Pérez was in charge of a Protestant Evangelical Center in San Pedro, California, which offered the typical gamut of social services associated with church-affiliated groups. Pérez became a Baptist when he was a young man and received free religious training in a seminary in Los Angeles. After completion of his course of study, he and his wife went to San Pedro to "do social work at the church, but only with the purpose of carrying the light of Jesus Christ to the hearts of all the brothers in order to convert them." Members of Pérez's congregation received free medical treatment and prescription drugs through the church clinic and had available to them, at no cost, a public bath, a library, English and citizenship classes, a kindergarten, and several social clubs. ${ }^{45}$

This is not to say that braceros came to the United States for the principal purpose of receiving charity. The overwhelming majority of emigrants left their native land in search of ways to improve their economic status or to place themselves in a safe environment. Once in the United States charitable services did play a decided role in inducing many workers to remain near their place of most recent employment and not return to Mexico when jobs were not readily available. Employers were also wont to take advantage of these institutions' services so that their employees did not stray far off during the off-season.

By mid-1929 Mexican migrants had settled in all areas of the United States. The vast majority of legal entrants, approximately 90 percent of them, indicated to border officials that their intended place of residence would be in the five states of the Southwest: Texas, New Mexico, Arizona, California, and Colorado. Only 10 percent said they would go to a state other than those five. It was obvious, however, that because of the attraction of wages in interior areas many thousands did not stay near the border as they originally intended: of the 1,422,533 Mexicans recorded in the federal census of 1930 , about 15 percent or almost 200,000 people resided in states other than the five nearest the border. Even this figure must be considered as inexact as by the time of the census date, April 1, the economic downturn of the Great Depression had already decimated all bracero colonies throughout the United States. Thus the exact magnitude of this internal migration cannot be measured, but the state of Texas, with a Mexican population of 683,681 persons in 1930 , the largest of any state, served as the principal source of supply for the population movement. Employers in Texas became so vexed by this loss of braceros that they had their state legislature enact an emigrant labor agency law in 1929 to hamper the contracting of laborers by out-of-state parties. ${ }^{46}$ 
The following statistics from the census of 1930 give a good idea of the increasing geographic mobility of Mexican migrants. States with a reported bracero population of less than one thousand have been excluded from Table 5.2.

TABLE 5.2

Mexican Immigrants in Selected States as of April 1, 1930

\begin{tabular}{lrlr}
\hline State & Number & State & Number \\
\hline Arizona & 144,173 & Montana & 2,571 \\
California & 368,013 & Nebraska & 6,321 \\
Colorado & 57,676 & Nevada & 3,090 \\
Idaho & 1,278 & New Mexico & 59,340 \\
Illinios & 28,906 & New York & 2,898 \\
Indiana & 9,642 & Ohio & 4,037 \\
Iowa & 4,295 & Oklahoma & 7,354 \\
Kansas & 19,150 & Oregon & 1,568 \\
Louisiana & 4,552 & Pennsylvania & 3,405 \\
Michigan & 13,336 & Texas & 683,681 \\
Minnesota & 3,626 & Utah & 4,012 \\
Mississippi & 1,221 & Wisconsin & 2,396 \\
Missouri & 4,989 & Wyoming & 7,174 \\
\hline
\end{tabular}

On the eve of the Great Depression it appeared that the Mexican community in the United States was beginning to follow the classic assimilation path evinced by other immigrant groups. As Gamio realized, most braceros were "automatically and inevitably incorporated into the lowest American social strata" at the time of their arrival. This condition was doubtlessly true for the vast majority of immigrants by the end of the decade, but it was not true for all of them. The observer of this seemingly monolithic mass could discern the beginnings of a more complex social differentiation.

Certain individuals had made important economic gains; not all worked in arduous manual labor. Paul S. Taylor found that in Chicago, for example, there were perhaps two hundred Mexicans in clerical and retail work. While members of this group tended to be more noticably white than many other Mexicans and came from the middle or lower middle classes of Mexican society, they had emigrated only recently. Chicago also had an emerging middle class composed of people who had engaged in manual labor upon first coming to the United States. Yet by 1928 over two hundred places of business had been established by these workers. A few braceros were beginning to ascend the economic ladder into American middle class respectability despite the many limitations imposed upon them in their new homeland. ${ }^{47}$ 
Income was often utilized to obtain the trappings which signaled further the assimilative process. One study of one hundred Mexican families in San Diego, California, showed that with the exception of food consumption patterns Mexicans and their families had adopted the American standard of living. An average of 30 percent of all disposable income was used to acquire items such as cars, radios, clothing, and homes. Eighty of the families had investments for the future, that is, they had purchased income property, life, health, and accident insurance, and had bank savings. A high percentage of money was spent for leisure time activities, and twenty-six families in the group had purchased an automobile. ${ }^{48}$

As was true of natives of the United States, many Mexicans flocked to urban areas in search of better living conditions. The census of 1930 showed that 50.8 percent of all braceros lived in urban areas, a total of 723,296 people. And in those areas the median size of their families was slightly less than that of their counterparts in rural areas. They had begun to purchase homes and investment properties. In Los Angeles 18.6 percent of all Mexicans were landowners; in San Antonio, Corpus Christi, Tucson, and Fresno, about one-third were homeowners. The resultant change in employment patterns after this shift to the cities meant that members of the group comprised a large minority of the industrial labor force ${ }^{49}$

The momentum of these economic and occupational gains carried over to attempts at psychological and political assimilation. Perhaps the best known and most important attempt to foster acculturation was the creation in 1928 of the League of United Latin American Citizens, or LULAC, in Texas. LULAC's major purposes were to end the maltreatment of Mexicans and Mexican Americans caused by the prejudice and discrimination of many United States citizens, and to accelerate the assimilative process. LULAC urged its members to learn English, to exercise faithfully the rights and duties allowed them under the law, and to pursue educational experiences to encourage the emergence of more professional people. . $^{50}$

The large numbers of immigrants from Mexico in the late 1920s gave added cause for optimism in the betterment and orderly growth of the Mexican-descent community in the United States. Yet the scope of this population flow remains one of the most perplexing problems of this period of history. Registration figures kept by United States immigration authorities are inadequate to use as an exact measurement because of the large number of wetbacks. Figures of the Mexican government also suffer from patently gross errors. One report, written at the end of 1928 by Andrés Landa y Piña, head of the Department of Migration, pointed out some of the discrepancies: more braceros returned to Mexico than had ever left the country. These same figures moved Gamio to remark sarcastically that the United States served as a "marvelous incubator" for Mexicans. ${ }^{51}$ 
There are a few tantalizing clues regarding the number of illegal entrants. In 1920 United States immigration officials believed that about 60,000 wetbacks entered their country each year through and around the port of Laredo, Texas. On the eve of the creation of the Border Patrol in 1924, Secretary of Labor James Davis informed the House of Representatives that in his opinion 200,000 to 300,000 braceros crossed the border surreptitiously from 1921 to 1924. The Mexican government's internal communications not only supported the general estimates of American authorities but also admitted that the majority of Mexican workers were in the United States in contravention of its laws. Secretary of Foreign Relations Genaro Estrada, after a careful scrutiny of the data available to his office from the consular corps in the United States, estimated that the expatriate community may have totaled 2,000,000 people, or about one eighth of Mexico's total population. ${ }^{52}$

It would be reasonable to assume, therefore, that during the 1920 s over 100,000 or so illegal entrants crossed the border yearly in addition to those recorded in the Annual Reports of the Commissioner General of Immigration (see Table 5.3).

TABLE 5.3

Legal Mexican Entrants Into the United States 1920-29

\begin{tabular}{cccr}
\hline $\begin{array}{c}\text { Year Ending } \\
\text { June } 30\end{array}$ & Immigrants & Non-Immigrants & Total \\
\hline 1920 & 51,042 & 17,350 & 68,392 \\
1921 & 29,603 & 17,191 & 46,794 \\
1922 & 18,246 & 12,049 & 30,295 \\
1923 & 62,709 & 13,279 & 75,988 \\
1924 & 87,648 & 18,139 & 105,787 \\
1925 & 32,378 & 17,351 & 49,729 \\
1926 & 42,638 & 17,147 & 59,785 \\
1927 & 66,766 & 13,873 & 80,639 \\
1928 & 57,765 & 3,857 & 61,622 \\
1929 & 38,980 & 3,405 & 42,385 \\
\hline
\end{tabular}

The census of 1930 provides another indirect measurement of the number of Mexicans who came to the United States during this decade. On April 1, $1930,1,422,533$ Mexicans were counted, a net increase of 936,113 when compared with the 486,418 returned in the census of 1920 . The figures from 1930 doubtlessly represent the fullest count taken during the period under discussion here. The "Mexican" category included all persons born in Mexico, or having parents born in Mexico, who were not white, black, or Oriental. When the Bureau of the Census extrapolated this definition to the census of 1920 , it estimated that there were then 700,541 Mexicans in the 
country. Over the ten-year period, then, there had been an increase in excess of 700,000 persons; more "Mexicans" were native born, a total of 805,535 , than were born in Mexico, 616,998 people.$^{53}$ One must remember, however, that even these rather high percentage increases still undercounted the number of braceros. Massive voluntary repatriation had been taking place during the fall and winter of 1929 . Had the census of 1930 been taken one year earlier it would have reported several hundred thousand more Mexicans.

Millions of Mexicans contributed to the rapid growth of the immigrant community throughout the United States. Many came for only short periods of time, and the tale of their journeys has been left largely unrecorded in our historical sources. Many others, judging by the birthplaces of their children and their acquisition of American trappings, came to stay. And it appeared their self-help and political action groups such as LULAC were on the way to an acceleration of the assimilative processes. The United States had become a permanent home for many. It was no longer a place of temporary refuge until things got better in their native land.

Mexico's economy did not recover from the shocks of the Revolution as expected. Employment remained scarce and wages miserably insufficient for the work that could be found. Rural conditions had remained unsettled because of the various schemes concerning land redistribution. Employers' needs in the United States for laborers easily overcame emotional and nationalistic ties to Mexico. Braceros quickly and very willingly moved into the vacuum created by the immigration laws of 1921 and 1924 , and they were received with open arms by governmental and private groups. It was the human desire for self-improvement which propelled emigration and led to the adoption of a new homeland for many of the expatriates. In the face of these strong commitments, anything done by Mexican revolutionary governments to control the exodus of their nationals proved to be largely ineffective. 


\section{Mexican Policies and Attitudes in the 1920s: New Urgency}

The responses of Mexican governments to emigration from 1921 to 1929 differed from those of earlier regimes. An immediate jolt came to newly elected President Álvaro Obregón at the end of 1920 when thousands of braceros who had lost their jobs were left stranded at points far from the border or dumped across the border for an unprepared Mexican government. Obregón heroically attempted to deal with the situation but quickly realized that he lacked the necessary funds, bureaucratic machinery, or cooperation from public and private groups in the United States. This searing experience showed the helplessness of the Mexican government in dealing with problems attendant to emigration and brought about a new intensity to the plans and policies of Mexican leaders for the remainder of the decade. To be sure, some features of attempted control mechanisms such as the propaganda campaign and consular protection were continued. What changed was their intensity and overall purpose. Mounting criticism, at times vitriolic, of the lack of effectiveness continued to pour forth and provided yet another sense of urgency and cause for increased governmental activity. New attempts to harness emigration for the benefit of Mexico proceeded in tandem with efforts to slow down the population exodus. The rampant inflation, violence, and other features of the military phase of the Revolution were gone, but more and more braceros left Mexico for the United States. It had become obvious that the root causes of emigration lay in structural defects within the Mexican economy and were not merely temporary, revolution-induced phenomena. If emigration had become a permanent feature stemming from the proximity of the two countries, then something had to be done to make use of it. 
The sudden end of wartime expansion in the United States confronted the Mexican government at the end of 1920. Inflated prices for farm products during the war had caused record crop production and the utilization of land formerly considered marginal. In the Rocky Mountain states, for example, irrigated acreage for various crops had more than doubled to a total of about 5,000,000 acres; nationwide, farm acreage had increased 9 percent from 1910 to 1920 . By the middle of 1920 , however, surplus food piled up in warehouses and prices dropped rapidly to below prewar levels. Nonagricultural sectors of the economy also underwent abrupt reverses. Mining and railroads, both of which had a high percentage of Mexican employees, suffered greatly in the recession. No precise statistics of unemployment exist, but it was estimated that about 5,000,000 men and women were jobless by October 1921. More than 100,000 businessmen declared bankruptcy and over 450,000 farmers lost their land. ${ }^{1}$

The unemployment rate for Mexicans was higher than that among the general working population. Of the 478,383 legal immigrants registered in the census of 1920, an estimated 100,000 lost their jobs. One cause of the higher rate of joblessness was a drive by organized labor and some political leaders to deport braceros so that their work would then be available for United States citizens. Samuel Gompers, president of the American Federation of Labor, urged his union affiliates to force Mexicans to change their citizenship or face expulsion from organized labor groups. While this extreme step was not undertaken on a wide scale, the rhetoric did signal a strong popular feeling that braceros should be the first to be laid off in a time of crisis. In other instances migrant workers were forced to leave their places of employment because of the fury of nativistic mobs. In Ranger, Texas, "night riders" abused Mexican families and destroyed their personal belongings. In Oklahoma bands of United States citizens threatened to burn down the dwellings of bracero families. ${ }^{2}$

Those left unemployed in rural areas suffered the most deprivation. In Saginaw, Michigan, the Michigan Beet Sugar Company let go its entire work force of 3,500 Mexicans. A federal immigration inspector who investigated living conditions there found braceros "living in a discarded box car. The box car was not partitioned. It [was] about as miserable a human habitation as I have ever seen ...." Other sugar beet companies in Michigan similarly abandoned about 1,500 additional workers. The most dramatic evidence of the harsh impact of the recession was found in Arizona's Salt River Valley. Members of the local growers' association planted only 66,502 acres of cotton in 1921 compared with almost 150,000 acres in 1920. By February 1921 an estimated 15,000 to 20,000 laborers and their families were unemployed, stranded, and on the verge of starvation. Throughout the West unemployment was rampant and worker discontent rose as employers slashed the wages of those with jobs. ${ }^{3}$ 
The economic downturn also caused high rates of industrial unemployment at points far from the border. Railroad companies, packing houses, steel mills, and other concerns in a variety of ventures had brought in thousands of Mexican laborers during the war, but in late 1920 many of these enterprises had to shut down completely or sharply curtail their working hours. No sooner had the business slump begun than thousands of braceros lost their jobs. In Chicago, Mexican consul Francisco Pereda wrote to Mayor William Thompson and complained that an untold number of his conationals were in a "most desperate poverty stricken condition." In New York City a "great number'" of Mexicans besieged the local consul in search of repatriation aid. In Philadelphia, Kansas City, Fort Worth, Dallas, San Antonio, and Los Angeles, similar horrendous conditions prevailed. ${ }^{4}$

Many politicians and spokesmen for private charity groups urged that the federal government conduct a massive deportation drive to rid the country of unemployed, indigent Mexicans. They argued that only the national government had the necessary funds and personnel to carry out the program, and that local and state bodies did not have the responsibility to care for the workers. Officials in the Department of Labor steadfastly rejected these suggestions. They said that most braceros had entered the country on their own initiative and, therefore, would receive no help from Washington. As for the 70,000 who had entered the United States in compliance with all the provisions of the wartime waivers, their employers had to pay for their return to Mexico. In short, the government did not want to set the precedent of helping indigent foreigners stranded in the United States. Nor were funds available to conduct a deportation drive. In March 1921 the Secretary of Labor did end the waivers put into force in 1917 and 1918 in order to make more employment available to citizens of the United States. Through the use of this device the federal government thus added greatly to the numbers of braceros who found themselves unemployed..$^{5}$

Nor was help forthcoming from other levels of government. The "Mexican problem" which was generated by the economic recession was most frequently viewed as the exclusive domain of federal authorities. Many county and city charity bureaus simply and routinely referred applications for assistance from indigent braceros to the Secretary of Labor's employees, arguing that immigrants who had taken no steps to change their citizenship came within the exclusive jurisdiction of federal authorities. Local organizations that were willing to help often had only pitifully small amounts of money at hand because of the general economic slump. On one occasion, E. R. Cockrell, Mayor of Fort Worth, Texas, wrote to President Obregón and informed him that his city's charity board had exhausted all of its funds in providing help to unemployed braceros and their families. Obregón then forewarded $\$ 5,000$ to Cockrell to supplement the depleted welfare fund ${ }^{6}$ 
The problems which confronted Obregón in Mexico did not always allow him to act as generously as he did in his dealings with Fort Worth officials. Mexico was also gripped by economic paralysis. The export of raw materials, a crucially important source of employment, tax revenues, and foreign exchange, plummeted at the end of 1920 . The value of silver exports dropped from $120,700,000$ pesos in 1920 to $76,900,000$ in 1921 ; copper sales abroad declined by more than two-thirds. Similar precipitous tax revenue losses resulted from a drop in the volume of cattle and henequen exports. In addition, a series of strikes further cut into industrial productivity. ${ }^{7}$ Something had to be done for the suffering Mexican communities in the United States despite all these handicaps. Daily consular reports and newspaper notices painted a grisly picture of the hardships faced by expatriate braceros. Mexico could not abandon her nationals both for humanitarian and practical considerations. Indeed, the possibility of doing nothing was not considered. Obregón knew that his response to the situation would be viewed as a test of both his political effectiveness in office and his commitment to the revolutionary tenet that revolutionary regimes had the welfare of the Mexican people as their primary concern.

The President quickly sketched out the administrative framework of repatriation, for in early 1921 there was no department of his government that had responsibility for the matter. Obregón was to direct all of the personnel involved in the project. Only he could authorize the expenditure of funds, and until the crises passed no other Mexican tax revenues were to leave the country for any purpose. Adolfo de la Huerta, Secretary of the Treasury, was to do all in the power of his office to have as much money as possible ready for Obregón's immediate disposal. All consular officials were ordered to obey dutifully chapter 30 of the department's regulations which made them primarily responsible for the protection of nationals outside the country. Consuls were to ensure the proper expenditure of funds authorized by the President and to oversee transportation arrangements as far as the border. The Secretary of Interior, nominally in charge of emigration and repatriation matters, assumed responsibility for the workers once they crossed the border and was to convey them to their home villages by railroad. On February 6, 1921, Obregón and his Secretary of Interior, Plutarco Calles, signed a memorandum of understanding which restricted the immigration of foreigners into Mexico for the duration of the crises. ${ }^{8}$

Obregón extensively used special commissioners in large consular districts where available diplomatic officials were too few in number to carry out his dictates. Several examples of this ad hoc arrangement clearly show the valuable assistance rendered by private citizens. On April 2, W. Jesús Chávez and other mine workers in Ray, Arizona, cabled Obregón and pleaded for help from him. Mines in the area had closed down indefinitely, leaving 275 
miners and their 1,016 dependents without resources. Starvation threatened the group if help did not come from some outside agency. Obregón wired Adolfo T. Pecina of Phoenix, Arizona, on April 4 and asked him to study the situation and inform him of the best course of action. Pecina was the director of the Liga Protectora Latina of Phoenix and had come to Obregón's attention because of his previous work in aiding destitute braceros. Pecina's report confirmed the conditions in Ray. He then sought out Mr. Boyd, president of the Consolidated Mining Company, and asked for assistance for Boyd's former employees. On April 8 Boyd offered to pay one-half of the workers' fares by train to the border, and he began to hand out free food to the most hard-pressed families. By April 13 about 100 families had left for the border with money provided by their former employer. Obregón ordered personnel of the Interior Department to have ready small amounts of money, food, and vouchers for second class rail fare to the interior of Mexico for the returnees. On April 15 Obregón ordered De la Huerta to cable $\$ 4,002$ to Pecina so that the remaining workers and their dependents could be repatriated. At the end of the month all of the Mexicans had left Ray, and Pecina was ordered to go to Jerome, Arizona, to deal with unemployed miners there ${ }^{9}$

The most intense efforts of Obregón's special envoys were directed at conditions in Arizona's Salt River Valley. One of the major causes of misery there was the failure of the Arizona Cotton Growers' Association to live up to its contractual promises. Each member of the group had contributed money to the Nogales Mexican Labor Association, a recruiting firm which sent agents into Mexico during the war. Braceros were induced to come to the United States through promises of good wages, steady employment, and money for transportation back to Mexico once the war had ended. Once the workers arrived in Arizona, however, it soon became obvious to them that most of the representations turned out to be false. The growers and their recruiting agency regularly induced many more workers to emigrate than were needed. Once in the Salt River Valley, employers then offered lower wages than had been promised and forced some workers to make their purchases of food and supplies at company stores. Then once the recession struck at the end of 1920 growers refused to pay the costs of repatriation, saying they could not afford this large outlay of cash. At the start of planting season in early 1921, the thousands of braceros who had remained through the winter in anticipation of spring employment were in the most desperate straits once the cutback in crop acreage became known. In and near the city of Phoenix alone over 10,000 Mexicans were on the verge of starvation. ${ }^{10}$

Obregón dispatched Los Angeles consul Eduardo Ruiz on January 29 to the Salt River Valley to investigate. Ruiz spoke to Governor Campbell and officers of the Growers' Association on February 1. Ruiz, at the urging of Obregón, threatened that his nation would never again allow braceros into Arizona if some agreement was not reached. After protracted negotiations 
which lasted until February 9 the three parties reached a consensus. The Association promised to live up to its word and pay the workers' train fares back to the border; it further stipulated that it would pay back wages owed to braceros by some of its members. The cotton growers did not, however, comply with this agreement, despite the good faith efforts of Ruiz. On March 21 Obregón was forced to authorize the consul in Phoenix to spend $\$ 17,000$ to alleviate the conditions of inadequate shelter and insufficient food which still confronted thousands of workers. Later, the President directed the Secretary of Foreign Relations to finance repatriation from the Salt River Valley for all braceros who wished to return to Mexico. Dr. Fernando Priego of Nogales, Sonora, was given $\$ 1,000$ to feed the returning workers and help speed them on their way to the interior. ${ }^{11}$

In urban areas Obregón's assistance was more effective if for no other reason than the concentration of braceros in a small geographic area. In Los Angeles Ruiz's successor Conrado Gaxiola set up a three-man repatriation board with instructions from the president that it aid only "those who have no job and are in extreme circumstances." Obregón authorized the expenditure of over $\$ 10,000$ for the committee's work in the city. Many destitute families received small sums of money for food and rent payments, and almost 2,000 people went from Los Angeles to Mazatlán, Sinaloa, on the ships México and San Pedro courtesy of Obregón's efforts. The President did caution Gaxiola on May 9 to admonish braceros with jobs not to abandon their positions. To do so would have unnecessarily added to the concerns of the government through this most "imprudent" action. Gaxiola was also instructed to investigate conditions in the Imperial Valley of southern California to see if work was available harvesting melon and other fruit crops. This alternative to unemployment in Los Angeles or Mexico was preferable, Obregón explained, as it did not throw on the shoulders of his government the fate of so many workers. ${ }^{12}$

In many other urban areas other ad hoc commissioners made strenuous efforts to aid braceros. Consul Ruiz made a swing tour of most major southwestern cities after his work in Phoenix was completed, and he reported to President Obregón that most of the special envoys had met with success in their work. In Fort Worth, Texas, Ruiz had given money to his needy countrymen and convinced some local employers to ship their former workers back to the border. In Dallas Obregóns's repatriation board had rendered assistance to braceros to the extent of $\$ 3,000$. Far to the north in Detroit the local Mexican consul and his civilian board of helpers succeeded in repatriating 5,500 braceros out of a total of 8,000 in a period of two months. ${ }^{13}$

Transportation costs had proven to be the largest single expense for Obregón's government regardless of the locale of the unemployed workers. Whereas a few dollars given to a family sufficed to buy food for some time, the cost of railroad tickets, even from points near the border, quickly mounted 
in the face of the tens of thousands who looked to their home government for help. For example, it cost $\$ 17.00$ for each passenger in a second class coach from Fort Worth to Laredo. Tickets from points farther north such as Michigan cost many times that amount. Large numbers of employers, despite their earlier promises, refused to pay this expense or offered to pay only the cost of tickets as of 1917 when the bracero workers were initially brought into the country. This latter solution more often than not proved unsatisfactory to Mexican officials. Consul Ruiz attempted to solve this problem of transportation when he asked several rail lines for permission to purchase large blocks of tickets at a discount price. His request was refused on the grounds that most rail corporations could think of no valid reason for giving special rates to the Mexican government. Obregón fired off a caustic telegram to the head of the Southern Pacific Railroad when he received this intelligence from Ruiz. He reminded the corporate president that thousands of Mexicans had toiled to help build his enterprise and had lent their services to many other sectors of the United States' economy. Now that large numbers of workers faced pressing difficulties, Obregón continued, would it not be just that a special ticket rate be devised so they could return to their native land? If railroads customarily offered reduced rates for tourists to come to Mexico, why could this not be done for their former employees? Through other channels the Southern Pacific made it known that it would not be "consistent" to comply with Obregón's request. ${ }^{14}$

Not all employers responded with such callous disregard for stranded braceros. Some sugar beet companies in Michigan returned hundreds of Mexicans to border cities. The United Verde Copper Company of Jerome, Arizona, gave food to unemployed miners and money for rail fare to Phoenix. The Kansas City, Mexico and Orient Railway of Texas lowered its fares to the border by 50 percent for returning Mexican nationals, bringing about a savings of over $\$ 17,000$ for Obregón's hard-pressed government. The repatriation movement also ended as quickly as it had begun. In July Obregón reported to the Congress that requests for aid had declined, and there was no longer any need for a special repatriation program. Over $\$ 1,000,000$ had been spent in Mexico and the United States to provide workers and their families with money, food, and transportation. Fifty thousand laborers, or about onehalf of all of those who had lost their jobs, had benefited from the efforts of the President, the consular corps, and private citizens. ${ }^{15}$

Little could be done to aid the repatriates once their journey home had ended. Many, back with friends and families and immersed in a familiar culture, doubtlessly were provided with a much-needed psychic balm. Most of the repatriates, however, faced one indisputable fact of economic life: the Revolution-ravaged Mexican economy could not provide them with a livelihood. Few jobs were available even with the federal restriction on immigration, and wages paid for work in Mexico paled in comparison to what had been customary in the United States. Obregón had pondered proposals to establish agrarian colonies for the returned workers and had received sugges- 
tions for many projects designed to reabsorb the braceros back into Mexican society. Whatever the merit of these plans, no practical results came about because of the shortage of resources. Mexico simply became a larger labor pool which awaited a quickening of the economy of the United States and the attendant need for more workers. At the end of 1921 notices abounded that the repatriates were for the most part unemployed and unemployable in their native land. Emigration started to gain momentum again in the spring of 1922 and would continue unabated until the onset of the Great Depression in 1929. It is probable that most people whom Obregón had strained his meager resources of money and personnel to return to Mexico were back in the United States within a year of the end of the repatriation movement. ${ }^{16}$

The lessons of 1921 were quickly learned and deeply remembered by Mexican political leaders in the 1920s. Many braceros who toiled in the United States became helpless in times of economic crises. Their value was high only in times of prosperity; in periods of retrenchment it was minimal. Ethnocentrism and the needs of employers and United States citizens at large dictated that Mexicans lost their jobs first. The unemployed could then look to few quarters for assistance. Promises which helped induce emigration were not kept, and the strained financial resources of public and private charity groups meant priority was given to helping United States citizens first. There was little the Mexican government could do to take control of the situation. It had little money to provide basic necessities for its expatriate citizens and was frequently reduced to begging, not always successfully, former employers for help in feeding and transporting braceros. Only empty threats could be put forth as bargaining chips: witness Ruiz's attempts to coerce Arizona cotton growers. Nor was the government's consular service in the United States sufficiently large to handle this sudden problem of such large dimensions. Special commissioners could be hired for the duration of the crises, but there was no established institution ready to act in league with Mexican consuls. The office of the Secretary of Foreign Relations did not have a bureau in charge of repatriation: the matter fell by default into Obregón's charge. The realization of the permanence of the population movement also began to develop. The Mexican government had few resources which would have permitted braceros to stay home. Perhaps at some time in the future a reconstructed Mexico could provide jobs for her citizens; for the time being, emigration provided a better alternative than restless unemployment at home. If Mexican citizens were to service the needs of the American economy, Mexico must become more of a beneficiary of emigration and the violent ups and downs of 1921 had to be avoided in the future. These were the lessons of 1921; they set the tone for the efforts of revolutionary regimes until 1929.

Despite the setbacks of 1921 , a small minority of Mexicans still continued to defend emigration as a long-term positive benefit. Manuel Gamio was the leading proponent of this point of view. His conclusions were based 
on his years of field research which resulted in the publication of his two books, The Mexican Immigrant and Mexican Immigration. He was firmly convinced that any population losses were only temporary. Once Mexico's industry and agriculture became fully developed, braceros would have no need to leave home for the United States. Nor were there dangers of assimilation for those who did cross the border: a large percentage of braceros were from indigenous groups. As such, they manifested enormous differences in tradition, language, and culture when compared with Americans. Moreover, their dark skin coloring would forever block their acceptance by the people of Anglo-Saxon America. ${ }^{17}$

Returning migrants-either tired of their stay abroad or rejected because of their backgrounds-greatly enriched their homeland in Gamio's view. Braceros easily and readily adopted the material culture of the United States. Tools, radios, and cars comprised the valuable baggage of repatriates and played a role in the material advancement of Mexico. These physical objects were only a small manifestation of a more important quality brought back to Mexico: a work ethic that would contribute to the growth of the Mexican middle class. Nor did Gamio fear the efforts of Protestant missionary workers. He believed there were few true conversions; instead, the bracero experienced only a nominal conversion based mostly on the material aid given to him. Writing at the height of the Cristero rebellion in the late 1920s, Gamio hoped that the exposure to non-Catholic religions would help combat the fanaticism and other evils inherent in many members of the Roman Church. ${ }^{18}$

Gamio remained a voice in the wilderness, however. It is instructive that his research findings were not published in Mexico until long after his death. His moderate, researched, and reasoned arguments were totally out of step with the general intellectual climate concerning emigration. Indeed, as the northward loss of population increased in the 1920 s it became clear that almost all public writers who addressed themselves to the matter saw little that would bring ultimate benefits to Mexico and her people. Newspapers set the tone of discussion through the use of highly slanted and emotional words and phrases. Editorial writers labeled expatriation as "suicidal" and "sterilizing and prejudicial" for Mexico. The doleful caravan of northward bound braceros had reduced Mexico to the status of an "exporter of human meat" for the United States. Gustavo Durón González, a member of the federal Chamber of Deputies, spoke for the majority of Mexican revolutionaries in 1925 when he wrote that all of the nation's wars meant little when compared to the shame of the losses incurred through emigration. ${ }^{19}$

Writers of fiction such as Rafael Muñoz also evinced alarm. This author had fled to California in 1916 because of his anti-Carranza sentiments and had worked in various jobs in that state. He returned to Mexico in 1920 and worked for a time as President Obregón's secretary. Later he was employed as a reporter for two Mexico City newspapers. His strongest statement concerning emigration is found in a short story entitled "El Repatriado," The 
Repatriate. Andrés returns to Mexico in 1913 after a temporary stay in California. He is barely recognizable as a Mexican because of his blue suit, pointed shoes, and hat. On the way to his home village, a revolutionary band of fighters captures him and forces him to join them as they roam about the area. The workings of Andrés's mind during all his experiences are presented as prime examples of how Americanization ruins good Mexicans. The repatriate has no thought of furthering the revolutionary cause, nor does he care to think of the political disturbance at all. Instead, Andrés can think only of a city with its tall, modern buildings and the other amenities found in the United States. His mind has no room for anything else. One day, lost in his thoughts and desirous of returning to the United States, he runs to a hilltop to see his city, and is shot and killed as a deserter. The narrator then describes the body, shoes covered with dust, the blue suit dirty and disarrayed. Only in death could mother Mexico reclaim one of her errant sons from the foolishness of the Yankee dream. ${ }^{20}$

Hand in hand with the growing hysteria of the late $1920 \mathrm{~s}$, newspaper editorialists and other writers began to analyze the root causes of emigration. These essayists saw economic dislocations as the primary cause for the flight of laborers. Mexico City's Excelsior urged rapid industrialization as the way to absorb unemployed rural braceros and avoid the attractions of the United States. Other writers lamented the "death of agriculture" in the new revolutionary order as the primary motivating cause. Revolutionary leaders were also blamed by a few brave editorialists. They were intolerable, "thieves and rogues," to a staff writer of Excelsior, who threatened the hard-earned resources of too many citizens through repeated political and economic experiments based on no order or reason. ${ }^{21}$

More scholarly examination of emigration also heartily criticized the loss of population during the decade. Gilberto Loyo was the main proponent of this school of demographic thought. He believed that the attainment of a high population density was compliance with the nationalistic goals of the Revolution. One important method of achieving this end was the reduction of the intensity of emigration by providing good jobs and adequate pay at home for workers. Another necessity was the establishment of a comprehensive government-sponsored repatriation program for all expatriates. Loyo saw little value in the braceros' journey beyond their enriching a foreign country and suffering untold abuses while their homeland continued to suffer the effects of low population density. Mexico could industrialize and enjoy the fruits of a rich agricultural industry only if she had more of her nationals available for those purposes. The vehemence of the arguments propounded by critics of emigration caused Mexican government leaders to attempt strong measures of control. ${ }^{22}$

Modifications within the bureaucratic structure were the first steps taken in an attempt to gain more control over the situation. In May 1921 Obregón established the Department of Repatriation within the Secretariat of Foreign 
Relations. Never again, it was hoped, would the nation's political leader be put in the storm center of an international crisis of this nature. Instead, consular officials in the United States were to establish standard procedures and have budgeted sums of money to aid in the funneling back of workers to Mexico when the need arose. In this way, Obregón wrote to his Secretary of Foreign Relations Alberto J. Pani, the new office would bring about "better efficiency and [less] loss of time" for all parties concerned. ${ }^{23}$

Obregón also sought to make use of the mutual benefit and self-help societies found in expatriate communities. These voluntary organizations had deep cultural roots in the Mexican community, and they had grown rapidly in number beginning around the turn of the century. The Mexican and Mexican American minority hoped that the financial resources they could muster would help to preserve their culture and to allow them prestige and influence in the wider American culture. One such group, the Alianza HispanoAmericana, based in Tucson, Arizona, had chapters established as far away as Wyoming, Chicago, Illinois, and in Mexico. Some of the benefits available for its members included life insurance, funeral expenses, a variety of social events, savings accounts, and youth leagues. In 1921 and 1922 some of the disposable funds of these groups had been utilized to aid a small number of indigent workers and to pay for some of their rail fares home. In late 1921 Obregón ordered all consuls to encourage the development of similar organizations in their districts. They were to be quasi-official bodies. Their officers and members received no pay from the government but were constantly assured of the importance of their roles. The Comisiones Honorificas (Honorary Commissions) were to be the eyes and ears of the consuls by keeping on the outlook for discriminatory treatment of Mexicans and reporting immediately to the consuls. Commission members were also to foster patriotism through the establishment of libraries and other cultural facilities and the observance of national holidays. The Brigadas de la Cruz Azul (Brigades of the Blue Cross) were intended to assist the Commissions in their roles, but their primary function was to ensure the welfare of braceros and their families. This was to be done through the establishment of a fund made up of small contributions from Mexicans in the area. When bad times befell a worker because of unemployment, accident, or death, his local Brigade would advance money during the crisis and, if necessary, provide transportation back to Mexico. ${ }^{24}$

The size of the consular corps was also expanded through the 1920s. Mexican diplomats, Obregón alleged, had frequently failed to exercise their protective role, and this had to become a thing of the past. There would have to be periodic, exact census data for all workers in each and every consular district, and it was the responsibility of the consuls to do this. There had to be more efficient compliance with the directives issued by Secretary Aguilar in 1916 and 1917: each case of denial of due process involving a Mexican citizen 
had to be accurately recorded and promptly reported to Mexico City for proper action. With the aid of the new workers' organizations, consuls now had a steady stream of information and could offer no excuses for dereliction of duty. To ensure more in-depth attention to these matters, the number of consuls in the United States grew from 51 in 1920 to 60 in 1929. ${ }^{25}$

Severe financial limitations impinged upon the effectiveness of these and other proposals of political leaders. Indeed, the chronic lack of funds accounts for the failure of almost every reform directed at emigration in the 1920s. Two major rebellions, that of Adolfo de la Huerta on 1923 and 1924 and the Cristero War of 1926 to 1929, and many smaller but no less expensive ones caused officials in power to relegate all plans for effective action to secondary importance. The Calles government could not give any support to Gamio's research, for example, for lack of money. What Gamio did accomplish was owed to help from the Social Science Research Council based in the United States. Propaganda efforts in Mexico had to be curtailed for the same reason; consuls more often than not had no resources with which they could help establish Honorary Commissions or Blue Cross groups; consular office staffs were usually well below the needed number of workers. The lack of money a vailable thus cast its shadow over all efforts to control emigration and protect nationals abroad. ${ }^{26}$

Lack of overall planning and study were also serious problems which flowed from this lack of financial resources. Prior to the Revolution of 1910 Mexico's statutory regulation of population movements was based on the Porfirian law of 1908. Its provisions spelled out the steps necessary for entering and exiting the country but did not mention the problem of population losses. The first proposed revision came in October 1923 when Obregón sent a bill to congress for its consideration. He called for the registration of all Mexicans in foreign nations and the contractual protection of rights accorded by the Constitution of 1917. Members of congress failed to vote on this bill and, instead, gave the President extraordinary powers to amend the Porfirian law. This resulted in the law of 1926, only the second in the twentieth century, which did not differ markedly from the proposal of $1923 .{ }^{27}$

The first attempt to ascertain overall goals came in August 1930 with the third Migration Law. Its provisions show clearly what had not been done in the $1920 \mathrm{~s}$. It created for the first time a national advisory commission on migration matters. This body was composed of the Secretaries of Interior, Foreign Relations, Communications and Public Works, Industry, and Agriculture, as well as personnel from the departments of Migration and $\mathrm{Na}$ tional Statistics. Commission members were to coordinate the policies of their various offices as they affected braceros; to determine an effective set of policies to control the exodus of laborers; to protect Mexicans in the United States; lastly, to find out why nationals had to emigrate in order to earn their living. There had been unsatisfactory management of all these areas during 
the preceding decade. Without long-range planning or sufficient funding, and despite the harsh realities of 1921-22, what may be discerned as emigration policy in the 1920s is largely the result of ad hoc, hit-or-miss activities on the part of Mexican political leaders. ${ }^{28}$

An ambitious proposal made in June 1922 demonstrates the high hopes and ultimate failures of the Mexican government. Economic conditions were deplorable, and most members of the lower classes were suffering from elemental needs. Any money sent to relatives from braceros in the United States helped to alleviate poverty and put a damper on the radicalism of would-be rebels. According to the government's information, the migrant workers remitted on the average $\$ 300.00$ per year to Mexico. In addition to helping poverty-stricken nationals at home, this sizeable amount of money also helped to lower the customary trade deficit with the United States. Labor could be looked upon as an exported commodity the same as any material good.

Furthermore, the large number of "exported" Mexicans might prove valuable as a pressure group on the United States government when it formulated its diplomatic policy toward Mexico. Diplomatic relations between the two nations had been broken in 1920 when Obregón and his allies ousted Carranza from power. American oil companies were the chief obstacle to recognition because of their insistence on a formal commitment from Obregón that certain provisions of the Constitution of 1917 would not be retroactive, and would not affect their property rights in Mexico. On the other hand, the Mexican government had allies in the United States who pressed for recognition. Included in this latter group were local chambers of commerce in the Southwest, several governors of border states, and many import-export businesses which traded with Mexico. The bracero presence in the United States accomplished several purposes in this scheme. Those who urged recognition were helped by emigration because of their heavy dependence on bracero labor. Obregón had no intention of hurting the interests of his allies. As for the oil companies and other property holders in Mexico, it was hoped by the planners that braceros would put pressure on the American government by voting and speaking up on the issue of recognition. Presumably, this would lessen the influence of certain investors on official policy.

Policymakers in June 1922 were also heartily impressed by the actions of their Italian and Polish counterparts. Members of the latter two nationalities who had gone to the United States were on approximately the same educational level as Mexican immigrants, and they had responded to their home governments' overtures by remitting millions of dollars to their homelands through banking channels. They were also ardent supporters of their own ethnicity and manifested their support through the celebration of patriotic holidays, schools, and political action groups. Mexicans believed these developments had taken place because of the "care and love" (cuidado $y$ cariño) shown to Poles and Italians by their native governments through 
consular protection. If Mexico could show she cared for her expatriates by duplicating the program of the European nations, her braceros would then reward her with patriotic, cultural, and financial suppport. ${ }^{29}$

Nothing came from this proposal. Obregón and his advisers looked to the emigrants to finance the establishment of more consular offices and cultural centers through payment of a small head tax paid upon departure; those already in the United States were asked for voluntary contributions. More often than not workers proved unwilling or unable to come up with the requested money; those exiting the country pleaded poverty and usually promised to contribute something later. Strapped for funds, consuls in the United States found it impossible to organize large numbers of migratory workers into any type of effective group. In addition, many workers evinced open distrust of these schemes. Some feared they were being persecuted by their home government for their political beliefs; others, especially those who were illegal entrants, wanted no contact whatsoever with officials. Other handicaps stemmed from the inability of Obregón's officials to discern natural leaders in the bracero community or to convey to the workers that they really cared about them. When the recognition was finally granted in August, 1923, it was largely because of Obregón's acquiesence to the oil companies' demands. ${ }^{30}$

Nor was it possible through changes in Mexico's economic structure to keep some workers at home. One effort to correct poor living and working conditions in rural areas came with Obregón's agrarian proposal of August 2, 1923. The preamble of the law signaled his intent to create a class of small landowners in order to stop the "great number of rural proletariat [who] constantly emigrate ... in search of better fortune" and return in worse condition than when they left. This law failed to effect this desired purpose. The lack of money on the part of would-be property owners, general disturbances in the countryside, and the government's inability to extend meaningful assistance, all combined to render the law ineffective in discouraging emigration. ${ }^{31}$

Despite all these frustrations, Presidents Obregón, Calles, and Portes Gil believed that it was not in the best interest of their country to halt the labor exodus. In addition to the political and monetary benefits discussed in the memorandum of June 1922, emigration was believed to bring certain salutary religious influences. The status of the Catholic Church in Mexico was a hotly debated issue after 1910. At issue were questions such as the registration of priests with the government, parochial schools, and the proper role of clergymen in domestic politics. Friction over these matters had resulted in continual skirmishes and had culminated in the Cristero war. Obregón and Calles viewed Catholicism as a negative influence for Mexico's modernization as it tended to obstruct the development of a sorely needed middle class. Returning braceros provided an element of hope for the revolutionaries. They had frequently been in contact with Protestant proselytizers, and many of them spread ideas of Freemasonry in an attempt to instill efficiency in workers and 
small landowners. The repatriates viewed churchmen as their major enemy and the sole cause of Mexico's misfortunes. They constantly attacked religious workers as representatives of a backward, superstitious way of life. This minor side effect of migration was most welcome by revolutionary leaders and gave added impetus to the arguments which saw Mexico benefiting from the exodus to the United States. ${ }^{32}$

It would be well to summarize here the problems and dilemmas faced by policymakers in the 1920s. The postwar recession revealed Mexico's inability to cope with emigration in times of economic downtum because of lack of funds, bureaucracy, and long-term planning. The ugliness of the repatriation drive combined with the vehemence of domestic concern dictated that quick and effective action was needed from revolutionary leaders. If this was not forthcoming, questions might arise as to the various regimes' commitments to certain tenets of the Revolution. Obstacles to these new formulations, however, were towering. There was the severe shortage of money in public coffers. Compared with the many urgent problems facing Obregón and Calles, the irritation of emigration paled. The benefits of labor expatriation for Mexico were just as obvious as they had been in the preceeding decade. What had to change was the quality and intensity of the policies initiated by Carranza. Official propaganda poured from the press as the first step in convincing workers to stay at home if they felt they could not cope with conditions in the United States.

Alfonso Fábila's El problema de la emigración de obreros y campesinos mexicanos represented the most extreme example of anti-emigration literature. The author claimed to have traveled extensively throughout the United States and assured his readers that his profile of bracero life was accurate. Fábila acknowledged that Mexican workers received higher wages, but he also damned them for depriving Mexico of their labor. He then proceeded to describe the typical emigrant's life across the border. The American climate was either too hot or too cold and had a harmful effect on health. Work supervisors created a living hell for the worker as they subjected him to long, brutal working hours which quite often led to blindness or rheumatism. Discrimination and prejudice were also rampant in the United States because of the Mexican laborer's swarthy skin coloring. In many instances overt hostility and murder resulted from this nefarious American racism. Moral standards also degenerated quickly in the United States. Sexual debauchery was widespread in migrant labor camps because of the large number of unmarried men and women who worked there. Fully 25 percent of all female emigrants practiced prostitution in urban areas, Fábila solemnly assured his readers, because of the bad example provided by American women. ${ }^{33}$

Other government publications, although not as transparent as Fábila's assertions, continued to signal the many dangers to be avoided. Arizona cotton companies were continually excoriated for their betrayals of 1921 and 
1922. Other typical conditions alleged to surround all Mexican nationals were unjust jail terms, vagrancy, blatant discrimination, and murder. There was also an intensive effort to inform migrants of the legal requirements necessary to enter the United States. Posters in train stations and oral warnings from federal employees clearly stated applicable statutory tests and fees that one had to meet and pay. To do differently would be to risk jail or worse. It was better to stay at home than to subject oneself to these terrible dangers. ${ }^{34}$

This war of words failed just as it had during Carranza's rule. Most braceros paid little attention to it. If the spokesmen of the Revolution were unable to provide jobs at home despite all the rhetoric about a new, reborn Mexico, why should their stories about the horrors of the United States be believed? The outright misrepresentations of the government made all of its arguments incredible. Oscar Harper, vice consul at Torreón, one of the main funnels to the north via the rail system, was told by 85 percent of his applicants for entry that they had been in the United States previously and had received good treatment. There were, of course, many dangers to be averted in the United States, and a campaign designed to inform workers how to avoid possibly dangerous situations and rectify injustices once they had occurred would have done far more to foster "care and love" than the near-hysterical half-truths that were propagated. The government's arguments for not emigrating simply broadcast the twin admissions that the Revolution had failed and the home government could not keep its nationals at home. The protective and paternalistic self-image conveyed in propaganda statements may have assuaged the zealots, but it did little to provide jobs and security for Mexican workers. The latter went abroad in search of work and self-betterment while the politicians stayed at home spinning their yarns. ${ }^{35}$

Administrative procedures were also employed to impede the exit of unprotected workers. In September 1924, Obregón established new migration offices in the interior rail centers of Empalme de González and Irapuato in Guanajuato, and at Sonoyta and Yavaros in Sonora near the border. In April 1930, when it appeared that economic conditions in the United States would halt emigration only temporarily, President Portes Gil reinforced the network of migration offices when he opened new branches in the rail centers of Guadalajara, Torreón, and Monterrey. The director of the national railroads was ordered in April 1925 to cooperate fully with migration officers by selling tickets to emigrants only in locations where migration personnel were located. It was hoped in this way that no tickets would be sold to those seeking to leave the country without a valid work contract. Migration agents were also to ride on all northbound trains and remove and send back all those thought to be going to the United States without proper documents. At the same time, requirements for legal entry into the United States were explained with precision so that Mexicans would be apprised of what lay ahead for wetbacks. ${ }^{36}$

All of these administrative procedures failed to carry out the intent of the 
government. Some individuals were undoubtedly persuaded not to cross the border, but the growing number of workers who fled Mexico during the 1920s is evidence of overall failure. Peasant mistrust helped cause the failure, but a more basic mechanism was the attitudes of officials in the Department of Migration. Many, for humanitarian reasons, felt they could not deny their countrymen a chance for a better life. Many more, if not most, according to the accusations pouring out of Mexico City, took advantage of the situation for self-enrichment. They regularly cooperated with coyotes and labor recruiters by serving as contact men for workers wishing to go to the United States. ${ }^{37}$

The repatriation policy of the Mexican government was also designed to help dissuade emigration. A memorandum probably written in January 1923 by an employee of the Department of Repatriation established this policy of refusing to finance the return journey of indigent individuals from the United States. The drain on the public treasury during the 1921-22 crises, in excess of $\$ 1,000,000$, had been severe but justified because of the large number of Mexicans who were in need of assistance. In many instances, however, it had been determined that braceros had abused this aid either because they had ample personal resources for the return journey or they had no intention of remaining permanently in Mexico. Barring another major economic downturn, therefore, the Secretary of Foreign Relations and members of his staff, would refuse to entertain requests for repatriation unless they were "'absolutely justified.",38

There was strict adherence to these guidelines. Migrants who had what Obregón called "certain comfortable means" such as a car, furniture, or farm animals were disallowed any help from their government either to get to the border or to travel to their home villages. Consuls spurned all inquiries from those who had jobs in the United States, telling them they would not be provided with free vacations by the government. Other applicants for assistance were told in less bald terms that no money was available for purposes of repatriation: the emigrant had voluntarily placed himself in his current difficulties despite the many warnings of officials and it was now his sole responsibility to extricate himself. If the individual refused to come to the government by joining in its schemes to harness emigration, then the government had no obligation to aid the worker when he was in trouble. ${ }^{39}$

Help was usually forthcoming when large numbers of Mexicans were involved. In large part this exception to general policy was to save face. Great numbers of indigents abandoned by the government would raise questions as to political leaders' commitment to the welfare of Mexicans in general. Opposition newspapers and politicians might seize on these situations to make telling political points. Thus, when two or three thousand indigent braceros in Ciudad Juárez asked for transportation to their home villages in the central plateau, Secretary of Interior Calles provided a twenty-five car train for that 
purpose. Calles wrote Obregon that, although he was displeased with the request the "state of misery in which they arrive [home] will be the best propaganda to stem further similar attempts to emigrate." 40

Presidents following Carranza greatly expanded the drive to protect nationals who were already in the United States. As was the case during the first decade of the Revolution, the failure to keep workers in Mexico gave rise to a more intense effort to care for them in the United States. At the direction of Obregón in 1921 consuls were instructed to file a report with the Secretary of Foreign Relations concerning every migrant worker who had been jailed in their jurisdiction. The report was to contain the name, profession, and birthplace of the accused as well as the exact nature of the imputed crime. Consuls also had to file information about any irregularities in police and judicial procedures against the accused. Officials who had not given enough attention to these matters in the past were severely reprimanded and reminded to "omit no effort whatsoever" to aid and protect their fellow citizens. If, after study, the Secretary of Foreign Relations determined that due process had been denied, diplomatic action would be taken through the consuls who were to do all possible to redress wrongs and remind local authorities of the value of Mexican laborers to the vitality of the local economy. ${ }^{41}$

The scope of consular duties was also expanded. Consuls were to help unemployed braceros to find work and were responsible for obtaining material aid for them until a job could be found. To carry out the latter duty, officials made certain all possible sources of public and private charity were contacted for assistance. Consuls also kept an eye out for acts of discrimination. Especially in areas of south Texas, local American authorities attempted on many occasions to place migrants under the proscriptions of Jim Crow laws so that Mexicans could not frequent the same places that whites did. Instances of anti-Mexican propaganda, used at times by candidates for local office in attempts to attract nativist votes, were another related concern. To combat these forms of racial and ethnic hatred, consuls actively sought public forums to point out the fallacies of the bigots' arguments. They also lodged formal complaints, through the Secretary of Foreign Relations, with the federal government in Washington. ${ }^{42}$

Consular staffs were expanded whenever possible to fulfill these new obligations. Since there was usually not enough money to pay the salaries of additional employees, consuls designated certain braceros as their unpaid commissioners. These were individuals who were wary of ill treatment by Americans and who were anxious to provide assistance to the Mexican government. One commissioner, Simón Nájera, carried out this function for many years while employed by the Santa Fe Railroad in Arizona. On other occasions, special presidential. agents aided consuls in areas of heavy Mexican settlement to deal with especially pressing problems. ${ }^{43}$

Consuls and their assistants on their own initiative often provided the 
most effective protection for braceros in the United States. Their home government could not finance and coordinate an effective nationwide campaign, but many bureaucrats did not interpret those facts as excuses for their own inaction. Protective efforts continued to attempt rectification of many of the same type of problems present before 1920. Consuls regularly visited work camps of companies that employed large numbers of braceros. Manuel Payno, the Mexican representative in Phoenix, Arizona, went to job sites and spoke to hundreds of Mexican workers. He inquired about working conditions, payment for services rendered, and acts of prejudice and discrimination. In January 1929 Payno heard complaints from two employees of the Santa Fe Railroad. One alleged he had been injured in a scuffle with an American employee of the firm, and another bracero said the company had an outhouse which bore a "white men only" sign on its front. Payno ascertained that both men were telling the truth, and he promptly went to an official of the railroad and asked that something be done to rectify the two situations. The official said he would take immediate steps to remove the sources of irritation. ${ }^{44}$

Consuls placed heavy emphasis on the battle for civil rights. Consul General Alejandro Carrillo, for example, was refused service in a cafe in Granger, Texas, and invited with his party of guests to eat in the kitchen. Carrillo immediately petitioned Governor Miriam Ferguson to ban all racial discrimination against Mexicans so that similar occurrences would not happen in the future. Instances of brutality and murder drew intense attention from the Mexican diplomatic corps. In the period immediately following World War I an average of one Mexican a week was lynched in the state of Texas. In November 1922 vigilantes in Weslaco, Texas, took Elias Villareal Zarate from a jail where he was awaiting trial and hanged him. Consul General Eduardo Ruiz complained to Governor Neff about the atrocity but felt he received no satisfactory response. Ruiz contacted Manuel Tellez, First Secretary of the Mexican Embassy, who then lodged a protest with Secretary of State Charles Evans Hughes. Hughes wired Neff to tell him he must take all necessary steps to protect Mexican immigrants in his state. Neff then rushed one hundred special law enforcement officers to Weslaco to apprehend the lynchers and prevent similar tragedies in the future. By January 1923 Tellez called attention to generally improved conditions in Texas for braceros. Mexican diplomats had helped to induce a stunning turnaround of the conditions confronting their fellow nationals. ${ }^{45}$

In Johnstown, Pennsylvania, similarly outrageous behavior was ended. Mayor Joseph Cauffiel tried to expel two thousand Mexican and black residents of his city after white-black race riots had brought about several deaths. When informed of the danger Tellez complained to Governor Gifford Pinchot and promptly received assurances from Pinchot that no such thing would be allowed to happen within the Commonwealth of Pennsylvania. In Gary, Indiana, the Mexican consul was instrumental in halting local police from 
making mass arrests and harrassing braceros each time a crime occurred in their neighborhoods. Because of the strong responses of these and other consular officials the Secretary of Foreign Relations could report in 1926 that overt, hostile acts motivated by racial prejudice had "diminished notably" against braceros in the United States. ${ }^{46}$

The successes of the Honorary Commissions and Blue Cross groups did not draw such uniform praise. Their functioning in the United States was hampered by manifold, insurmountable problems. Neither institution was capable of coalescing permanently large numbers of migrant workers. A group in existence one summer dissappeared by the winter as Mexicans in the area left to go on to their next employment site. This extreme fluidity contributed to a usually small membership: Consul General Santibáñez found it rare to have a group with more than fifty members. This small number dictated that any sums of money held in common were very minor. Enrique González, Santibáñez's successor, pointed out other pervasive causes of failure after an extensive inspection tour throughout the United States in 1929. One major obstacle was the lack of compensation for people who served as officers. Too few were willing to work for the sake of altruism, and, as a result, many of the planned units had been unable to attract any personnel. González went on to point out other difficulties: a lack of cooperative spirit among members of the migrant communities; Catholic Church resistance to government-sponsored groups; lack of organizational ability; and the low educational level of braceros and their families. The unwillingness of workers to make monetary contributions was also of paramount importance in understanding the lack of successes. ${ }^{47}$

Although neither strong nor numerous, Blue Cross chapters did aid many Mexicans at times. The experience of Luis Murillo typified what could be done by Blue Cross personnel. American immigration authorities wanted to deport Murillo after local police had arrested him on a charge of vagrancy. Murillo was blind, and, as he stood in the doorway of his room, an officer apprehended him. Blue Cross officials explained that he had always worked in the United States and there was no reason to send him back to Mexico. Immigration officials released the man. Members of the Blue Cross unit then secured medical treatment for Murillo to see if something could be done to correct his blindness. ${ }^{48}$

Some units provided valuable help for large numbers of braceros. In the Imperial Valley region of southern California hundreds of participants contributed $\$ 2.00$ per month in dues to Blue Cross chapters in Brawley, Calexico, and El Centro. The common funds mounted quickly because of the large numbers of Mexicans in the area during its long growing season. The money was employed, among other things, to build social centers, to provide free medical care and drugs, to provide 50 percent of a member's monthly wages to him in time of need, and to support Mexican holiday celebrations. 
Similar functions were carried out in the San Antonio, Texas, region where, again, the large number of expatriates allowed for the necessary funding and sustained interest. ${ }^{49}$

The activities of Honorary Commissions also showed mixed results. These organizations were handicapped by many of the same limitations that affected the Blue Cross units. In addition, no single chapter could be stronger than the consul it served. Where local diplomats showed little concern for bracero welfare, no information was passed on to them. When consular interest ran high, there was a corresponding interest from members of the Honorary Commissions. A consul was usually made the honorary president of each commission in these instances and tried to keep in frequent touch with these bodies so as to receive information. Patriotic celebrations were frequently and successfully sponsored.$^{50}$

The outcome of a cultural and patriotic campaign encouraged by the Obregón and Calles administrations is illustrative of the problems which confronted the Blue Cross and Honorary Commission efforts. Overall results were scant because of the inability of Mexican governments to finance proposed undertakings in the United States. As early as 1924 it was evident to many observers in Mexico that large numbers of braceros were being Americanized. Their native language and culture were giving way to those of the United States. The "melting pot" meant de-Mexicanization, and political commentators denounced the failure of their leaders to do anything about it. As an "exporter of human meat," an editorial in Excelsior stated, the Secretary of Public Education had the obligation to establish and fund a system of schools throughout the United States in order to counteract the on-going deculturation. Despite these criticisms, Obregón and Calles could not find the money for such a vast project. Indeed, their private correspondence shows they were unable to fund less ambitious programs such as the establishment of libraries. ${ }^{51}$

Efforts along these lines were therefore left to the initiative of local people. Consul Roberto Garciá of Albuquerque, New Mexico, constantly encouraged patriotism by traveling throughout his district and dispensing money gained from requests to Mexican and Mexican American businessmen. When he combined these contributions with money out of his own pocket, García was able to support several hundred celebrations each year. Other agents of the government hired part-time teachers who offered classes in history and geography. More often than not, Mexican communities failed to observe national holidays at all. ${ }^{52}$

Exasperation resulted from these sporadic efforts and successes. Santibáñez in his book Ensayo acerca de la inmigración mexicana, published in 1929 , signaled his disgust with the status quo when he wrote that nobody helped the average bracero in the United States; all workers were left to their own devices to cope with life across the border. This statement reflected more 
than one man's opinion, as Santibáñez's book was published with the encouragement and approval of President Portes Gil and Acting Secretary of Interior Felipe Canales. As early as 1923 Obregón had written to Mayor E. R. Cockrell of Fort Worth that his government had done everything it could to control emigration and protect workers in the United States, although it was obvious that much more remained to be done. Other high officials excoriated braceros for not contributing their money and energies to Blue Cross and Honorary Commission projects. If they did what they were told to do by their leaders, most of their difficulties in the United States would not have happened. In short, if there were problems they were the fault of the emigrants not the government, which had done its best under the pressing circumstances. ${ }^{53}$

An international treaty with the United States was perceived as an answer to these dilemmas. By early 1929 Mexican policymakers had come to realize fully the weaknesses of their unilateral approaches. Whereas they had repeatedly brought forth a series of failures and frustrations, their counterparts in the United States had easily controlled the entry of immigrants as well as the status of illegal entrants. In February 1929 Secretary of Foreign Relations Estrada made the first formal request for some type of arrangement. He argued that the labor needs of both nations could be met in a timely and adequate fashion after a conference worked out the details of an international program to regulate migration. Other spokesmen such as Santibáñez called for similar treaty obligations; Manuel Gamio espoused similar proposals in his writings. ${ }^{54}$

There was little interest in the United States for such an arrangement. Personnel within the executive branch of the government saw more to lose than gain by the adoption of these proposals. It was generally believed that temporary, regulated migration would be opposed by organized labor, and that braceros, as they had done during the exemptions of the World War I period, would not live up to their obligations. Presidents Coolidge and Hoover in league with the Department of State had clearly shown that they already had firm control over the question of Mexican immigration. In short, the present system was desirable as it was "better to accept a known evil than one unknown." Only Secretary of Labor Davis favored the proposal, but his pleas fell on deaf ears. Mexico would have no semblance of control over emigration until the bracero program in $1942 .{ }^{55}$

This last failure of the Mexican government on the eve of the Great Depression was typical of what had transpired throughout the 1920s. The decade began with a new political dynasty in power and a sharpened awareness of Mexico's precarious position in controlling emigration. The population movement continued apace only if the needs of the United States' economy dictated such. When the recession began in late 1920, Obregón found himself totally unprepared for what suddenly confronted him. He 
lacked money and any coherent plan to deal with repatriation. What had been viewed by Carranza as a temporary phenomenon now was perceived as a permanent, long-term development dictated by the geographical proximity of the United States and Mexico.

Efforts throughout the decade were the story of Mexican leaders' attempts to exercise effective management of emigration. They failed to do this. They lacked money to reform the domestic economy so as to remove one important cause of the labor exodus. They were not able to hire bureaucrats to protect braceros and develop effective planning. In the face of the rural folk's desires to improve their lot in life as they saw fit, the rudimentary efforts of Obregón, Calles, and Portes Gil came to naught. Only the commitment and humanitarianism of individual diplomatic agents in the United States brought sporadic success for expatriates. By February 1929 Mexican planners admitted to themselves the fruitlessness of their efforts and turned for assistance to their American counterparts. But by that late date the executive branch of the United States' government had already determined the fate of emigration through its own unilateral efforts. 


\section{American Policy and Attitudes, 1918 to 1930}

The government of the United States acted quickly, efficiently, and decisively to control the flow of Mexican immigration. This is not to say that policymakers in Washington and along the border spoke for a unified consensus concerning braceros. Indeed, this issue caused one of the most intensely debated concerns in the twentieth century. Many business and church groups favored a continuation of immigration for different reasons. Protestant missionaries saw Mexicans as a great challenge. If they could be converted, the migrants would assimilate easily into the society of their new homeland if they decided to remain, or would change Mexico for the better if they decided to return. Spokesmen for the Catholic Church also encouraged this influx of population, believing it contributed strength for their religious organization. Employers of Mexican laborers argued their immediate economic needs as justification for an open-door policy along the border. Native workers continued to scorn farm work in the 1920s, and European immigrants did not come to the United States in large numbers because of the country's new, highly restrictive immigration laws. The health of large parts of the economy thereby became heavily dependent on braceros.

Republican administrations in the 1920 s allied themselves with these pro-immigration groups but for largely different motivations. Politicians, led by Herbert Hoover, viewed the question of the bracero within the wider context of expanding trade and investments throughout Latin America. If the United States was to be a good neighbor and a welcome investor, it had to treat Latin Americans as equals. They must not be singled out for discriminatory treatment. The treatment of the Mexican bracero in the United States, therefore, became a crucial test which measured the true intentions of 
the United States toward Latin America. Immigration was allowed to continue unabated through frequent noncompliance with federal statutes which would have limited the entry of Mexicans. Only under the threat of a nativist quota in the latter part of the decade did government leaders begin systematically to apply federal legislation on the Mexican border in order to forestall a worsening of diplomatic relations with Mexico in particular and Latin America in general.

Nativists in the tribal twenties doubtlessly represented the majority opinion of the country when they tried to include bracero immigration within the provisions of the Immigration Act of 1924. This legislation was the high tide of the belief that racial homogeneity was necessary to ensure the continuing progress of the United States. With this state of mind prevalent it was only natural that an attempt was made to exclude Mexicans from the United States. Restrictionists argued for their cause on economic grounds, saying the braceros depressed wages and frustrated the betterment of citizens. Their major contentions were based on the supposed racial inferiority of the Mexican immigrants. Southern and eastern Europeans, and earlier Asians, were excluded in 1924 because they were deemed unable to assimilate or, indeed, even to comprehend the basic mechanisms of Anglo-Saxon democracy. The Mexican, largely uneducated, of Indian background, and fleeing from a turbulent political scene at home, was claimed to be inferior to those classes on whom the door had been shut in 1924 .

The many attempts to legislate a quota failed because of the congruence of interests of many politically powerful groups. Of paramount importance was the federal government which through a series of political countermoves and arm-twisting saw to it that no quota bill ever passed both houses of Congress. Employers and missionaries exerted pressure-the one political, the other moral-and linked their fortunes with administration maneuvers in Washington. The Mexican government clearly showed that it had little interest in limiting emigration, and applauded efforts in the United States to preclude the passage of a quota law. Once the Coolidge administration began to enforce federal legislation which excluded braceros, revolutionary leaders, caught in their own rhetoric, had no cause for complaint: the United States was not singling out Mexicans for discriminatory treatment; legal emigration was being lowered. Thus did the groups which favored immigration begin the first effective cutback of the northward flow of Mexican workers.

Protestant missionaries were one of the most vocal exponents of the minority view favoring large-scale immigration. They based their arguments on faith in their various denominations' God-given mission of conversion. The Protestants' view of Mexican Catholicism added urgency to the divine command. In the opinion of Methodist minister Vernon McCombs, for example, the braceros' original religion had largely degenerated to a state of 
ignorance and superstition because of "cold, grasping, exigent, and unreasonable, and often immoral" priests. Robert McLean, a Methodist Episcopal worker with Mexican migrants, felt Catholicism was not only a sham but, more importantly, an obstacle to Americanization. How, he asked, could future citizens of the United States be trained properly by political refugees from Mexico who did not speak English, did not understand American ideals, and in many cases were hostile to them? Missionaries who knew and could impart the "proper" ideals were put forth as the alternative to priests and nuns. ${ }^{1}$

The Revolution of 1910 and its aftermath had created a unique opportunity for missionaries. They believed that Mexican history had come to a watershed which was destroying the old, evil ways. The Church, a scar of the past according to McCombs, took on particular importance in this interpretation of Mexico's evolution. Pre-conquest Indians had had the last true religion in Mexico because their beliefs, although pagan, were in strict accord with their level of cultural development and provided pervasive spiritual comfort. The Spanish conquest of 1521 imposed Christianity upon the Indians only at the point of a sword and the barrel of a gun. Inquisitorial persecution during the colonial period soon rooted out all public vestiges of the pagan religions. The Church thus offered only oppression, never salvation or a moral code to Mexicans. This static nature of religion, the missionaries believed, had been greatly jolted by the Revolution of 1910 which brought with it a search for newer and better spiritual guidance. Protestants were ordained by God to move into this vacuum not only to make religious converts but also to bring Mexicans the American way of life. As expressed by Samuel Guy Inman, probably the most prolific missionary polemicist of the time, the Revolution "is not a revolution to be crushed, but an evolution to be guided." 2

Nor did religious leaders doubt they lacked the human clay to mold in this conversion process. The Mexican Indian was seen as the equal of any other human being found in the United States. Indigenous peoples had built and sustained one of the most advanced civilizations in the world prior to 1521 , and in the twentieth century their descendants were "capable of accomplishing anything that the Creator may ask of His creatures." This was not to say there were not many obstacles to Americanization. Jay Stowell claimed that most braceros and their families were "un-American and unfitted both in principle and practice to the needs of the Twentieth Century." He went on to describe these undesirable traits as ignorance, bigotry, and superstition. In sharp distinction to nativists, however, missionaries ascribed the Mexicans' drawbacks to environmental factors and not to inherent genetic causes. Catholicism made the bracero a liar because the Church freely sold indulgences for sins and made him sexually promiscuous because of the artificially high charge for the marriage ceremony. If witchcraft abounded, it 
was because priests and nuns had provided no substitute for pagan practices. Poor health, ignorance of hygiene, and lack of energy were caused by unsanitary food, lack of education, and insufficient nutrition. ${ }^{3}$

The new environment of the United States would bring about the end of all these disabilities. The Reverend Edwin Brown of the American Baptist Home Mission Society summed up this hope when he wrote:

Here is the amazing spectacle of vast multitudes of unevangelized people living in the very shadows of the most missionary churches in the world. Now they find themselves in the land of the free, with old inhibitions and limitations suddenly removed, and their minds and hearts and souls open to the impact of the new, the strange, the different .... They represent a harvest field white and ready for the reaping .... We should get out the checkbook of missionary zeal, and drawing upon the illimitable funds of faith, purchase great harvesters, man them with adequate forces, and send them forth to reap. ${ }^{4}$

One important goal of the effort to bring in great harvests was the creation of upright citizens of the United States. The religious workers believed that Protestantism and the American way of life were one and indivisible; therefore, Mexican converts to their various denominations would not have to face the problems inherent in assimilation. Dedicated Christian service would beget pure Americans, and the secular education found in the United States would instill a further profound appreciation for its democracy and working institutions. $^{5}$

Appeals for understanding and toleration from the general public were part and parcel of this campaign of human regeneration. As a counter to strong nativist feelings, missionaries argued that citizens of Mexico and the United States had more similarities than differences. People in each group were imbued with a democratic spirit because of their long struggle to tame the wilderness of the New World. If this spirit had been largely latent in Mexico in the past, the Revolution of 1910 allowed it to come to the fore. Both groups were also said to be peace loving in contrast to the constant rivalries and wars in Europe; this shared characteristic was, again, attributed to the long ordeal of civilizing the Americas. Americans and Mexicans also had high hopes and abiding faith that the future held nothing but progress for both of their nations. "There are," Robert E. Speer pleaded to the public of the United States, "elements of union to bind us together across the chasm of race" once the American people decided to ignore braceros' biological antecedents. The all too common patterns of discrimination and prejudice had to be stopped and replaced with Christian love and understanding, the true ideals of America, the American people, and Protestantism. Once this transition had taken place, supposed traits of inferiority and superiority would evaporate; both peoples would live in complete harmony. The adopted country of the immigrants would benefit greatly by this rapid assimilative process. ${ }^{6}$ 
Proselytizers also believed that migration greatly benefited Mexico. One minister put forth Francisco I. Madero as a prime example of what education in the United States could do for Mexico. His training in Maryland at a Catholic high school and in California at the University of California at Berkeley had "plastered" him with the American ideals of progress and political reform which he had employed to end the Porfirian dictatorship and open up the new era in his homeland. As Bishop Wilber Thirkeld of the Methodist Episcopal Church told a reporter of the Pittsburgh Post: "They are an opportunity for America. If we'll set the American flag flying in their hearts, if we lift them up to our standards and ideals, we may send hundreds of them back as evangels of the new and larger life in Mexico." 7

Protestant leaders argued a further benefit for both countries: good diplomatic relations. Political leaders of both nations were said to be unmindful of the radical departure brought about by the Revolution. American politicians had to realize that there had been created a great opportunity to spread American ideals; Mexican leaders had to see this transformation process through the eyes of the missionaries. How was this to be accomplished? When thousands of braceros returned to Mexico after a pleasant stay in the United States, not only would they provide examples of the "new and larger" life but they would also act as ambassadors of goodwill. They would be so anxious to spread the word of the United States' good intentions that they would force their government to give up its obduracy in diplomatic dealings. ${ }^{8}$

The American government, too, must change its ways. Instead of concentrating upon the few American lives lost and the relatively small amount of property destroyed in Mexico, diplomacy should concentrate on more important, longer-lasting, matters. Most claims by private citizens against revolutionary governments should be paid by the Treasury Department in Washington and not be pressed upon the government in Mexico City. This would remove a constant irritant which had been blown out of proportion as domestic politicians exploited the issue for the sake of a few votes in their home districts. Immigration should continue unhindered by even minimal restrictions: at stake were Mexican souls, something no earthly institution could preclude from salvation. Public meetings criticized in bitter terms any suggestions that a quota be placed on future immigration. If this action were taken, the example of the United States would be denied to braceros, ill will would result between the United States and all Latin American countries, and the prospects of evangelization would be lessened. ${ }^{9}$

Protestants were political bedfellows with spokesmen for the Catholic Church on the issue of Mexican immigration. Catholics generally saw the United States as a much-needed sanctuary for those fleeing the unwarranted anticlericalism of revolutionaries. There was little fear that the efforts of Protestants would attract a substantial percentage of immigrants: in a tolerant 
atmosphere, braceros would practice the only religion they had known and believed in for centuries. Indeed, in the absence of organized repression Mexican Catholics soon became a strong pillar of the Church. The immigrant, historically the bedrock of strength in a largely Protestant nation, was sorely needed:

It is very probable that there has been no loss at all, beyond the defection of Catholics which ordinarily takes place among any population due to the weakness of human nature and the usual manifestations of the same.... It is due to immigration that the Catholic Church in America today [1925] stands out among her sister Churches of other nations, the equal of any .... [If this immigration had not taken place] the Church in the United States, scattered over the immense expanse of the nation, would very probably today be a replica of the Church of 1790 , a weak, anemic body. ${ }^{10}$

The Church west of the Mississippi was numerically weaker in comparison to areas in the eastern part of the nation. Catholics comprised a mere 7.5 percent of the West's total population but did account for 20 percent of all Catholics in the United States. In vast territorial areas proper religious services were lacking. There was only one priest for every 465 square miles of land; one church for every 380 square miles. In some districts the large area of individual parishes was astounding: each priest in Salt Lake City was responsible for 6,022 square miles; in Tucson, each priest had to service an area of 2,146 square miles. Within this setting, Churchmen welcomed Mexicans with open arms as a means to swell the numbers of their coreligionists, to increase Church wealth, and to provide a potential source for future religious workers, particularly among the Spanish-speaking groups of the West. The Church's Extension Society sent priests to work camps where they provided religious services and distributed money and food to workers and their families in times of need. In El Paso, the National Catholic Immigrant Aid organization helped facilitate the legal entry of braceros by providing clerical and legal assistance."

Businessmen whose continuing prosperity depended upon Mexican workers were the most ardent public advocates of unrestricted immigration and went to the most extreme lengths to effect a favorable climate of opinion in the United States in the 1920s. Employers were anxious to show that the Mexican presented little or no danger to the American way of life in order to ensure their supply of laborers and preclude the inclusion of Mexico within the restrictive provisions of the nativist Immigration Act of 1924. To persuade the majority of the validity of this position, they claimed that braceros were a unique docile group of people, denuded of ambition and complacent with their status in life as a result of centuries of servitude and brutal exploitation on the haciendas. As one farmer told Paul Taylor, "he's just like a dog; slap him 
and he'll lick your hand.' Moreover, this line of reasoning continued, Mexicans had no political ambitions and were content to live under the rule of American political bosses. ${ }^{12}$

It was claimed that the braceros' physical and mental makeup ideally suited them for manual labor. The hot climate of Mexico and the demanding tasks of hacienda labor had conditioned them to withstand high temperatures and carry out stoop labor. This being the case, the "betters" of society, the whites, were allowed to pursue occupations more appropriate to their superior station in life. Many interpreted the Mexican' generally swarthy skin as a mark of God. He intended dark skin coloring as a mark of inferior status. If He had not wanted the immigrants to be hewers of wood and drawers of water, He would have given them white coloring. C. V. Maddus, a spokesman for the Great Western Sugar Company, addressed himself to the psychological makeup of his company's thousands of farmhands from Mexico and called them a "God-fearing, family-loving, law-abiding set of people.' A supervisor for the Southern Pacific Railroad asserted braceros to be cheerful, humble, clean, religious, brave, sober, and music-loving. How could it be argued that they posed any potential threat for the American way of life? ${ }^{13}$

These beliefs concerning the Mexican were based upon the nearuniversal assumption of the time that certain races and ethnic groups manifested certain innate characteristics because of their unique genetic makeup. John Nance Garner, a representative from Texas, argued in 1920, for example, that braceros could never make particularly desirable citizens because of their innate inferiority to whites, but there was nothing to worry about in any event because of the genetically determined "homing pigeon" mechanism which carried most of them back to Mexico. Others claimed that Mexicans were people of a "tropical citizenship;" that is, if they remained in the United States for any length of time, the colder climate would cause them to die of consumption or, at the very least, to suffer terribly from pneumonia. ${ }^{14}$

Many other examples of the racial determinism of pro-immigration employers could be listed, but the point is that they, if anything, tried to outdo nativists in portraying the Mexican as an inferior being. One reason for this was the consensus regarding the inferiority of most "non-Nordic" peoples. Another, more important cause, was related to the employers' tactics in defeating quota legislation. They portrayed braceros as so inferior, so low on the scale of human abilities, so as to deny the presence of any political and social dangers for American civilization. Few truly wanted Mexicans in the United States, but many needed them.

The most persuasive and true argument of employers in the 1920s was that braceros were an indispensable element in the economy. As S. Parker Friselle, a representative of the California Federated Farm Bureau, expressed 
it to the House Committee on Immigration and Naturalization in 1926, "We, gentlemen, are just as anxious as you are not to build the civilization of California or any other western district upon a Mexican foundation. We take him because there is nothing else available to us .... We have no choice in the matter." 15 Without migrants to plant, tend, harvest, and process crops, large areas of agricultural production would have faced near-ruination within a short period of time. The president of the Orange County Farm Bureau spelled out the economic implications of a labor shortage in his area: the $\$ 38,000,000$ annual production of citrus fruits and other produce would almost disappear. In all of California bracero labor was largely responsible for an annual agricultural production of $\$ 466,000,000$ and a total investment in excess of $\$ 3,000,000,000$. Employers in other states had an equally heavy reliance on the Mexican. ${ }^{16}$

Dire predictions of disaster also came from other business groups. Chambers of commerce, whose members were heavily dependent on the prosperity of local rural economies, forecast a serious commercial depression if railroad workers from Mexico were not available to local farmers. Railroads claimed they would have to shut down if they were deprived of braceros. The attitude of the business community was best expressed in an intensive nationwide survey carried out by the United States Chamber of Commerce in 1929. It showed that without Mexican labor the continued economic development of the Southwest, large parts of the West, and sections of the Midwest would be severely impeded or suddenly halted. A quota on immigration would directly affect in an adverse manner employers such as railroads, hotels, packinghouses, mines, and factories. There simply was no other group of workers from any source available to fill the millions of unskilled, low-paid jobs needed for the continuing economic vitality of those industries. Indirectly, a cutoff of the supply of braceros would hinder those industries because of the depression which agricultural interests would suffer. This close relationship between rural and urban prosperity was put in the following analogy by Friselle in 1926: "You gentlemen know the importance of agriculture in America. You know that the cities are merely the service stations for the country. The back country is what keeps the ball rolling. If we are to develop your prosperity and ours, it depends upon the success of our agricultural program.",17

Employers became the most vociferous critics of any attempts to limit the number of Mexican immigrants. They comprised the bulk of the witnesses who spoke against congressional attempts to formulate a quota law in the late 1920s. Spokesmen for chambers of commerce, growers, irrigation projects, the tourist industry, mining and smelter interests, and food processors innundated legislators and members of the executive branch of the federal government with pleas and petitions not to limit the influx of braceros. Senators and Representatives also spoke up for the interests of their local districts, and, 
more importantly, voted against restrictionist quota bills when they came to the floor of their chambers. This relatively small group thus proved to be very powerful in obtaining what it wanted and needed from the national government. ${ }^{18}$

The policy of the federal government in the 1920s also favored migration from Mexico. This favorable attitude can best be understood in the context of Republican foreign policy. Beginning with the Revolution of 1910 in Mexico, diplomatic relations between the two countries had been characterized by mutual confusion and irritation as revolutionaries sought to end or alter certain Porfirian practices. In response to these often violent shifts, reactions from Washington were often varied and unstable. President Wilson's orders to occupy the port of Vera Cruz and send General Pershing into Mexico in search of Villa are the two most dramatic examples of the uncertainties of the period. When Wilson left office in March 1921 there were good reasons for ending this state of affairs. Secretary of Commerce Herbert Hoover mapped out a new Mexican policy which was designed, in part, to favor American businessmen. The principal goal was foreign economic expansion in the form of overseas investments and trade. ${ }^{19}$

Hoover manifested his interest in Latin America as soon as he assumed his post in the federal government in 1921 . His request that he be appointed Chairman of the Inter-American High Commission was granted by President Harding, and Hoover used that post to foster the growth of commercial relations with all Latin American countries. As he stated his purpose in 1921, "the more our intercommerce expands, the more certain is the development of our long established friendships [with Latin American nations].' Because of this post and his position as Secretary of Commerce, Hoover quickly established his control over New World economic affairs as they affected the United States. So successful were his efforts that by 1929 total American investments in Latin America exceeded $\$ 3,500,000 .^{20}$

Hoover's goals and methods were accepted by other important policymakers in the 1920s. Charles Evans Hughes, Secretary of State from 1921 to 1924 , opened a new era in relations between the United States and Mexico in 1923. His new policy was to grant automatic recognition to any Mexican government which exercised de facto power without applying Wilsonian moral judgments as to the mode of gaining power. The United States later repudiated the Roosevelt corollary to the Monroe Doctrine which sought to justify, on grounds of self-protection, intervention in Latin American internal affairs. Frank B. Kellogg, Secretary of State from 1925 to 1929, also was keenly interested in increasing trade with Latin America and viewed good relations with Mexico as a gauge of the United States' intentions to all Spanish-speaking areas. Hoover welcomed the appointment of Dwight Morrow as ambassador to Mexico in 1928. Morrow had been a partner in the J. P. Morgan investment house; he favored peaceful relations with Mexico in order 
to create a favorable climate for American trade and investments. Morrow established a good rapport with President Calles and helped to persuade the Mexican leader to slow down revolutionary programs which endangered stability and the legal status of foreign-owned enterprises. ${ }^{21}$

The question of Mexican immigration was a potential irritant to this grand design. Republicans on the whole were solidly in favor of keeping out foreigners and had supported the restrictionist laws of 1921 and 1924. In part, this had been done to curry favor with organized labor; in part, it was done as a reflection of the era's strong feeling of nativism. Hoover supported both of these sentiments in general terms, but difficulties arose, he wrote Representative John E. Raker in 1924, in determining the "proper methods" to achieve the goal. He regularly received copies of consular reports which analyzed the causes and directions of emigration and informed him that arbitrary steps to reduce immigration from Mexico would be ill received by revolutionary leaders who might retaliate by obstructing expanded trade and investments. For these reasons, the executive branch of the United States government took many steps in the 1920 s to facilitate the influx of braceros. ${ }^{22}$

Another motivation of Republican governments was to aid the stability of Mexico. It was realized that the outflow of unemployed men and women removed a potential source of rebels and troublemakers for revolutionary leaders and provided braceros with a livelihood unavailable in their own land. The large sums of money remitted by expatriates also helped family members who did not emigrate and provided an element of economic stability for Mexico. These effects of immigration to the United States added to the Mexican scene elements of stability and long-term growth and, by implication, the potential for trade and investment. At all costs a repetition of the horrendous destruction of the 1910-20 period with its baleful effects on American lives and property had to be avoided. ${ }^{23}$

The racial classification of incoming workers was a highly crucial issue. The Immigration Act of 1924 barred the entry of persons with more than 50 percent Indian blood. It is probable that Albert Johnson, the Representative who authored the bill, included this provision so as to bar the immigration of large numbers of Canadian Indians into his home state of Washington. Any attempts to apply this part of the law along the Mexican border might have resulted in disaster. There had been multiple instances of prejudice and discrimination against braceros, and these acts were a chronic sore point in relations between the two nations. Attempts to exclude Mexicans of Indian ancestry would be interpreted as support by the United States government of the racism of many of its citizens, and as arbitrary treatment. Furthermore, enforcement of the law might have given officials in the state of Texas one more reason to attempt to include braceros under the provisions of Jim Crow laws. Because of the great latitude in powers allowed the states under the doctrine of states' rights at the time, there would then be little the federal 
government could do to affect state actions, but the fine distinctions of American constitutional law made little difference to Mexican authorities. In any event, it would have been impossible to enforce the law because of the complexities, racially and culturally, of the immigrant group. Many people whom the Mexicans classified on a cultural level as mestizos were pure Indian by any biological test. Faced with thousands of laborers and dependents whose physical appearances ranged from "pure white" to "obviously Indian," who could decide those to be excluded? ${ }^{24}$

To preclude these difficulties, immigration authorities simply classified all incoming Mexicans as "white." The exclusion clause of the law of 1924 therefore became null and void along the Mexican border, and all branches of the federal government used this definition of the Mexican for all types of catagories. This policy prevented confusion at the border, avoided the "ill effects" of problems with the Mexican government, and prevented "a lot of work and diplomatic explaining," in the words of one consular official, to account for the actions of the state of Texas. ${ }^{25}$

The federal government also did what it could to ensure an ample supply of laborers for employers in order to aid domestic economic expansion. Political leaders in the 1920 s accepted at face value the argument that ruination would ensue for large areas of the economy if braceros were not available in large numbers. To facilitate the inflow of labor, legal restrictions on immigration were never vigorously enforced along the border until 1928, and members of the Border Patrol were kept preoccupied with the enforcement of customs and prohibition laws. The United States Department of Immigration also did what it could to keep wetbacks in the country. The Los Angeles Daily Times first exposed this practice in February 1926 when it printed an interview with I. F. Wixon, Chief of the Immigration Bureau. Wixon stated that illegal entrants had not been and would not be deported if they were apprehended by his employees. Instead, they or their employers had to pay $\$ 18.00$ to the nearest chamber of commerce. That organization then forewarded the money to Wixon's office to pay for the worker's visa $(\$ 10.00)$ and head tax charge $(\$ 8.00)$. The bracero was then brought to the nearest border entry point and allowed to enter the United States legally. When queried about this practice Commissioner General of Immigration Harry Hull made no apologies. He wrote that because of the Southwest's heavy dependence on Mexican labor, the strict enforcement of federal laws would only produce acute shortages of manpower and result in serious harm to the local economy. ${ }^{26}$

Rarely were attempts made to search for illegal entrants for the purpose of deportation. In the typical field office of the Immigration Bureau there were thousands or hundreds of thousands of wetbacks spread over a large geographical area. Many local citizens were heavily dependent on this source of laborers and would not have cooperated with a deportation campaign; 
Department of Labor employees who would have had to carry out this activity more often than not lacked the personnel and funds to do so. Illegal aliens were thus largely left alone to pursue their employment. The only exceptions to this general practice were braceros who came to official notice through arrests, court convictions, and applications for charity. In these latter instances Immigration personnel moved speedily to investigate and, if possible, deport the Mexican in question. Deportees made no contribution to the local economy: they had committed the error of trying to drain local resources. Since these relatively few acts to oust braceros were in compliance with federal statues, they occasioned no complaints from the Mexican government. ${ }^{27}$

The Department of Immigration also allowed private employers to lure braceros into the country illegally. In 1921, after the end of the wartime waiver, a representative of the Arizona Cotton Growers Association asked for the government's cooperation in securing field hands. He argued that cotton production would fall if an ample number of Mexicans were not brought across the border. Federal authorities accepted the growers' contention and gave them permission to send a recruiter into Mexico in search of workers. Once the recruiter found people willing to go to Arizona, he gave them a note which promised that the Association would pay the $\$ 8.00$ head tax stipulated by law. The paper was accepted by immigration officers, and the Association became liable for payment. This system of labor importation, in contravention of the contract labor law of 1885 and other statutes, lasted through 1922, and during the two years of its operation the growers were able to bring in about 4,000 braceros..$^{28}$

Many other steps were taken to foster the growth of the American economy and international goodwill. The head tax of $\$ 8.00$ paid by each legal immigrant was, of course, a heavy burden for many workers, particularly those who came with their families. Throughout the decade this law was not construed by officials of the Departments of State and Labor to apply to those who remained in the United States for less than six months. Thus, those who came to work for only one season were refunded this entry fee when they left the country. Samuel Sokobin, American consul in Saltillo, wrote a forty-page review of other practices carried out in the 1920s to facilitate immigration. He found that consuls generally gave a more than lenient interpretation to federal laws and regulations if an applicant for a visa had illegally resided in the United States prior to the time of application. Although this practice had no legal justification, diplomatic officers apparently felt that such people were well on their way to productive lives and should be allowed to legalize their status. Sokobin also criticized border area personnel for their lackadaisical attention to documents proffered by would-be immigrants. Often these "proofs" of civil status were blatant forgeries, but they were usually accepted at face value. ${ }^{29}$ 
In summary, the groups that urged an easy acceptance of Mexican immigration controlled governmental policy in the 1920s. Protestant and Catholic clergymen strongly supported the immense population movement with the expectation it would provide new sheep for their folds. Employers wished a continuation of the status quo for the more practical reason that braceros made up the bulk of the unskilled laboring force in the Southwest and in industries far from the border. Their hopes for continuing prosperity would not have been reflected in the federal government's policy had it not been for the congruence of their interests with those of Republican leaders. The benign attitudes of politicians and bureaucrats reflected a more basic concern than the vitality of the domestic economy: at stake was the desire to foster American economic influence through Latin America. The most immediate test of the good-neighbor policy took place along the border with Mexico. Hoover and his fellow Republicans saw to it that the test was passed successfully.

This course of action, however, was not without its critics. As immigration mounted, so too did a campaign to halt it. This development was not surprising. The decade saw the high point of nativism and its culmination in the Immigration Act of 1924. If racial and cultural homogeneity were generally accepted as prerequisites for national greatness and progress, there had to be an attempt to halt or at least to lower the number of Mexicans who immigrated. The intensity and seeming coherence of the efforts and arguments of restrictionists in the latter part of the decade brought about the most incisive questioning of the government's policy and, ultimately, its end.

Those who opposed the inflow of Mexican nationals based their arguments on three main points: economic, cultural, and racial. Organized labor was in the forefront of opposition for economic reasons. Samuel Gompers, president of the American Federation of Labor (AFL) until 1924, claimed that braceros, willing to work for comparatively low wages, depressed the entire western wage structure and caused suffering and hardship for local citizens. William Green, Gompers' successor, voiced similar complaints about the influx of low-paid foreign workers. Organized labor rejected the contention that domestic workers were unavailable for unskilled work. What was needed was an adequate wage for the work; if this were established, then an ample supply of labor would surface ${ }^{30}$

Influential friends of the labor union movement also joined in this sentiment. Early in 1927, Harry Hull publicly opposed Mexican immigration along with Secretary of Labor James Davis. Both men had become alarmed at the increasingly open border and the resultant threat implicit in the situation to all of the country's restrictive immigration laws. Both also said that braceros drove down wages and worsened the working and living conditions of the poor. These two men were the only important administration officials who publicly sided with the arguments of the groups advocating a Mexican quota. Hull became the most vehement spokesman for this cause when, in March 
1930, he condemned labor recruiters who ignored the practical effects of importing Mexican workers. He pointed out that rapid technological changes had lessened the need for manual labor and brought unemployment to many workers. With this situation it was disastrous not to give whatever work was available to the recently unemployed native citizens. The continuing importation, he warned, created a "moving drama in economics, social life, and citizenship which [was] ending with unneccessary tragedy for American workers." 31

Some who favored a quota also argued that the braceros ruined the agricultural system of the United States. Just as black slaves had driven a multitude of small farmers from their lands in the early nineteenth century, so too did Mexicans in the 1920s. Employers with large plots of land, because of their economic advantage with large numbers of low-paid workers, monopolized the rural landscape and gave rise to a modern plantation system. This social displacement forced Americans into a marginal existence, roaming aimlessly in rural areas or living tortured lives in urban areas. ${ }^{32}$

The most vehement and emotional opposition to immigration doubtlessly came from those who argued their point of view on the cultural and biological grounds of saving the American way of life. Biological theory provided the intellectual premise for this pseudoscientific stance. A strong strain of thought viewed the Mexican people as living fossils in the garden of evolutionary development. They had lost out in the struggle for existence and lacked not only the desire for personal gain, but, more importantly, the potential for civilization. The "best" people for the United States came from certain areas of northern and western Europe. They were:

the English, Dutch, Swedes, Germans, and even the Scotch-Irish, who constituted practically the entire immigration prior to 1890. [All these groups] were less than two thousand years ago one Germanic race in the forests surrounding the North Sea. Thus, being similar in blood and political ideals, social training and economic background, this "old" immigration has merged with the native stock fairly easily and rapidly. ${ }^{33}$

The Mexican stood in sharp contrast to these "good" immigrants. One striking feature of the genre of polemics which described Mexicans is the imagery of insects, animals, and germs. Several examples of this highly imflammatory rhetoric document the total contempt evinced for the Mexican. C. M. Goethe, president of the privately financed Immigration Study Commission, referred to the immigrants as "low-powered eugenically," and stated that "the peon problem, biologically, is akin to the English sparrow problem." To Frederick Russel Burnham the laborers and their families were a "creeping blight" much like the boll weevil which plagued southern cotton 
fields. Albert Johnson feared for the well-being of the Republic because of the arrival of "ever-recurring new foci of infection." 34

Statements of Mexican inferiority had developed well before the 1920s and may be traced to before the war between the two countries. What had changed by the third decade of the twentieth century was the near-universal nature of these claims and the allegedly scientific basis for them which relied upon the biological theory of the time. This idea of race determinism was first articulated to the general public in Madison Grant's The Passing of the Great Race, published in 1916. Grant posited the greatness of the United States as a reflection of the immigration of the Nordic races of northern and western Europe. Democracy flourished among these people because they were the white race par excellence; no other group had ever or could ever reach their level of attainment. In Grant's view the greatest danger facing the United States was the immigration of non-Nordic people who threatened to dilute and then destroy American civilization because of their alien religions, races, and political creeds. Mexicans, a "population of race bastards," were a prime example of the inferior races of the world. The more prolific Mexican Indian with his "bad" blood had bred out of existence the "good" white blood of the Spaniards. The resultant hybrid mestizo inherited only the bad traits of both parent groups: he was mentally and morally crippled and had no capacity for self-government. ${ }^{35}$

Later writers popularized and expanded upon Grant's ideas. Braceros, wrote Robert Foerster in a report submitted to the Secretary of Labor in 1925, had not developed an effective democracy in their own country because of innate inferiority. To allow the continuing immigration of this group of people to the United States courted the disasters of racial inundation and the end of the American way of life. There was no question in the racist mind of the prolific nature of immigrants. C. M. Goethe expressed this belief in the following terms: the average American family had three children while the Mexican family had nine or ten offspring. At this rate the former couple had 27 great-grandchildren while the latter had 729 . Within a few generations Mexicans would control the United States through the sheer weight of numbers because of this geometric rate of increase. The "English sparrow" would soon come to submerge the eagle. ${ }^{36}$

Ironically, the then-current pseudoscientific beliefs portrayed miscegination as an additional cause of Mexican inferiority. As if the undesirable traits of the Indian and the southern European Spaniard were not enough, the creation of the mestizo generated another layer of characteristics abhorred by nativists. The immigrant was often labeled as clannish, autocratic, and prone to strong drink. Why had the white racial component not washed out some of these "Indian" traits? Foerster admitted that the causes of this phenomenon were far from completely understood, but he wrote that a large body of presumptive knowledge showed that interbreeding between 
two races resulted in "various disharmonic or asymmetrical developments which prevent a normal and balanced life." In short, the Mexican could probably abide by life in the United States but not advance or sustain it ${ }^{37}$

Another claim of some nativists was that Mexicans were all potential political radicals. They could point to many instances of radicalism which grew out of the Revolution of 1910 and warn of its importation and the inherent dangers to Anglo-Saxon democracy. Proponents of a quota law attributed this trait to two causes. The bracero had had no contact with democratic institutions in his native land, and being "profoundly alien in blood, ideals, and outlook, [could only be] a destructive element" for his new homeland. Theodore Lothrop Stoddard then took this argument one step further and claimed that each and every immigrant was "potential revolutionary material, because he is a born communist. ${ }^{, 38}$

A strong current of popular opinion reflected the above opinions. The Chicago Daily Tribune, for example, held that southern and eastern Europeans had been rightly excluded from the country because of their inferiority and inability to assimilate. What was true of those white people was ten times so of Mexicans. Physically they were inferior, and their standard of living took for granted pervasive illiteracy and a tumultuous political tradition. If the brown men from Mexico were not kept out of the country, the editorialist concluded, every city in the United States would have its slum of unassimilable and unwanted Mexicans. Another writer expressed the fear that the entire Southwest was being Mexicanized and lost to the Anglo-Saxon people. What the United States had won by war in 1848 would be lost to it in the twentieth century through biological inundation. At times, state politicians ran for office on platforms which demanded that the federal government exclude "bloodthirsty" and "uncivilized" Mexicans who threatened to deprive "red-blooded" Americans of their rightful places in the scheme of things. ${ }^{39}$ This virulent racism was dramatically expressed by Dr. Roy Garis, a selfprofessed expert in eugenics and professor of economics at Vanderbilt University, when he wrote,

Their minds run to nothing higher than animal functions-eat, sleep, and sexual debauchery. In every huddle of Mexican shacks one meets the same idleness, hordes of hungry dogs, and filthy children with faces plastered with flies, disease, human filth, stench, promiscuous fornication, bastardy .... These people sleep by day and prowl by night like coyotes, stealing anything they can get their hands on, no matter how useless it may be .... Yet there are Americans clamoring for more of this human swine to be brought over from Mexico. ${ }^{40}$

Given the tone of these anti-Mexican beliefs, it was inevitable that efforts were made to limit the immigration of braceros. The times also appeared propitious for such a solution. Federal legislation had slowly but surely ex- 
panded the definition of those ineligible for entry into the United States beginning with the Chinese Exclusion Act of 1882. The literacy test imposed in 1917 had been proven very effective against certain Europeans but left Mexicans unaffected because of wartime exigencies. The quota laws of 1921 and 1924 permanently altered the ethnic composition of the nation's immigrant groups. The sense of these pieces of legislation, firmly supported by popular opinion, was for one major purpose: to keep most foreigners out of the country, especially those whose background was far removed from that of the citizens of the United States. Many efforts were made within this general context to limit the influx of Mexicans.

The earliest and most sustained efforts for immigration restriction came from leaders of organized labor. Samuel Gompers had accepted with great reluctance the federal government's decision to waive exclusionary laws for Mexican workers in 1917 and 1918. Immediately after the Allied victory in 1918 he stated that he no longer had "interest in Mexican labor other than to keep them from coming here to compete with our labor after the war." This position conformed to Gompers' general belief that most newcomers should be excluded from the United States in order to protect the wage structure and jobs of his union members. In 1919, with the strong support of other union leaders such as John L. Lewis of the United Mine Workers, the American Federation of Labor (AFL) went on record as strongly opposed to continuing Mexican immigration. ${ }^{41}$

Gompers' successor, William Green, continued this private campaign when he took office in 1925. Green enjoyed close ties with Luis Morones, head of the Confederación Regional de Obreros Mexicanos (CROM), and sought to have the Mexican labor leader agree to a policy of voluntary restriction. In August $1925 \mathrm{AFL}$ and CROM representatives met in Washington, D.C., in an attempt to reach a consensus. The differing interests of each organization, however, quickly made it clear that each had a different set of priorities. CROM spokesmen sought an end to discriminatory practices by AFL unions and asked that every bracero who crossed the border be given a membership card in an American union. The AFL delegates pressed for one major concession: that CROM would pressure the Calles government into taking strong measures to stop emigration, saying that the matter of Mexican union membership was left to the discretion of individual organizations and was not something which could be dictated. Since both parties were at loggerheads, their joint declaration at the end of the conference offered little in the way of keeping Mexican workers at home. In July 1928, after the assassination of President-elect Obregón, CROM's influence in Mexico waned as Morones was suspected of complicity in the crime. The AFL then abandoned Green's strategy and returned to its earlier policy of seeking to include Mexico in the provisions of the quota laws. ${ }^{42}$

Gompers had intensively lobbied for the inclusion of Mexico in the laws of 1921 and 1924. He found a willing ally in Secretary of Labor James Davis 
who also hoped to protect native workers and tighten up the generally lax enforcement of laws along the border. Gompers and Davis urged the inclusion of all New World countries in a quota so as to protect fully the United States against foreigners. Otherwise, the overall effect of the laws of 1921 and 1924 would be minimal considering the open "back door." Southern congressmen generally supported this position on the grounds of keeping out Latin Americans with their "colored blood." The Department of State in league with employers and missionaries fought against this amendment to the act, arguing that it would do irreparable harm to Pan American goodwill and the economy of the Southwest. ${ }^{43}$

Nativists accepted these positions in the early 1920 s, but only for reasons of political expediency. There was fear that if the question of bracero immigration was pressed in congress, large numbers of representatives from the West and Southwest would be forced to vote against the law of 1924 so as to protect the interests of their home districts. Representative Johnson, author of the bill, decided not to fight for this amendment because it might endanger passage of the entire law. For this reason, Mexico was excluded from the provisions of the law, but not without warnings from restrictionists that it was foolish to "leave the back door open" for braceros who were widely regarded as an inferior race. ${ }^{44}$

The congress of the United States became the arena of battle between advocates of restriction and free immigration after 1924. Three men led the pro-quota forces: Representatives John Box and Albert Johnson, and Senator William Harris. Johnson was first elected to congress in 1912 and in 1920 he became chairman of the House Committee on Immigration and Naturalization. Johnson was deeply concerned with racial purity. He often corresponded with Madison Grant and took The Passing of the Great Race as gospel. So deep was his concern regarding the dangers of "inferior" races that in 1923 Johnson accepted the presidency of the Eugenics Research Association. In the "Foreward" to Garis' book entitled Immigration Restriction, published in 1927, Johnson emphatically stated his purpose in extending the provisions of the law of 1924: "The United States is our land. If it was not the land of our fathers, at least it may be, and should be, the land of our children." 45

Box came to congress in 1920 and was a member of Johnson's committee. He was a native of Jacksonville, Texas, and the only one of the three men who had had personal contacts with Mexican workers. From his first term in congress, Box complained about the lack of enforcement of immigration laws along the border and the growing number of braceros in his home state. Box staked his political fortunes, in part, on adamant and racist statements which described braceros as ignorant, degraded, inferior, and savage. In 1928 he succinctly stated his views on the House floor, saying that "every reason which calls for the exclusion of the most wretched, ignorant, dirty, diseased, and degraded people of Europe or Asia demands that the illiterate, unclean, 
peonized masses moving this way from Mexico be stopped at the border." Harris represented Georgia in the Senate and pressed forth with similar views concerning non-Nordic immigrants: keep them out of the United States. ${ }^{46}$

By 1926, Johnson, Box, and Harris had given up hope that the administration would enforce even the provisions of the 1924 law along the length of the Mexican border. The stage was set for the inclusion of Mexico in the quota law. From 1926 to 1930 some proposed legislation was introduced in the congress every year. Three major bills surfaced. Johnson's proposal fixed a quota for all New World countries at a multiple of three times the number of United States citizens who emigrated to a particular country. This formula would have given Mexico an annual quota of about 2,175. Box's bill was even more stringent. It set an annual hemispheric quota of 50,000 and alloted only 1,500 of the total to Mexico. Harris's bill sought to apply the quota provisions of the Immigration Act of 1924 to Mexico alone. This would have limited the number of Mexican immigrants to about 1,800 a year. All these proposals were well within the mainstream of immigration legislation since 1882 , and a strong outpouring of public opinion supported some sort of quota against Mexico. ${ }^{47}$

The quota battle was fought on several levels. In congress five sets of hearings were held. Hundreds of witnesses who spoke as individuals or as representatives of special interest groups repeatedly presented the pro and con arguments discussed above. From the first series of debates in 1926 to the last in 1930 it was obvious a total deadlock existed. Neither faction conceded one point to the other: braceros were either the salvation of the American economy and a great opportunity for religious groups, or a looming threat to civilization in the United States. ${ }^{48}$

Members of the Coolidge and Hoover administrations publicly disagreed over the merits of a quota system once the issue had become a matter for congressional debate. Officials in the Department of Labor strongly endorsed some kind of limitation on the influx of Mexican workers. Commissioner Hull repeatedly appealed to the protection of the sovereignty of the nation. Since the "back door" was being kept open, the carefully drawn restrictive immigration laws of the country were becoming null and void. Mexicans and Europeans who were supposed to be excluded from the country streamed across the unguarded border. Hull freely heaped scorn upon congressmen for neglecting this long-overdue and pressing problem. Secretary of Labor Davis agreed with Hull's contentions and demanded immediate, urgent action to prevent what he called an impending breakdown of all immigration controls.$^{49}$

Davis was so vehement in his criticism that he was scolded by President Coolidge for his outcries. Secretary of State Frank B. Kellogg had written to Coolidge urging him to curb the actions of officials within the Department of Labor. If this were not done, Kellogg warned, Latin American nations would interpret the statements as an end of hemispheric goodwill. Coolidge, who 
relied heavily on Kellog and Hoover for foreign policy advice, wrote Davis that the question of immigration was a sensitive matter best left in the hands of spokesmen from the Department of State. Davis apologized to Coolidge, saying his statements were being made only with the best interests of the United States uppermost in mind; he had not attempted to intrude on diplomatic relations with other countries. ${ }^{50}$

Opponents of the quota were more numerous in the administration than those who supported it. Spokesmen from the Department of State took the lead in attacking the proposed legislation when they spoke before congressional committees and the public at large. Their arguments continued to revolve around Pan American goodwill and the profits to be gained from trade with Latin American countries. Officials from the Department of Agriculture and Bureau of the Interior also strongly spoke against any restrictions. To limit the supply of Mexican manpower, they said, would sharply curtail food production, irrigation projects, and the many other industries dependent on those two sectors of the economy. ${ }^{51}$

More than any other factor, the effect of a quota upon trade and investments stiffened the resolve of the executive branch to forestall any legislation at all. Kellogg ordered members of the diplomatic corps to ascertain governmental opinion in Latin America regarding this proposed action. This survey indicated the belief south of the Rio Grande that only the direst consequences would result. Latin Americans believed that international travel and communication should be as free as possible except for minor administrative regulations. "Very strong"' replies showed that a quota would "deeply wound" the feelings of Latin Americans, and they would feel obligated to take strong retaliatory measures. This reaction, Kellogg stated, would undo the long-term, arduous labors so dutifully done since 1920 and harm the national interests of the United States. At stake was an investment in excess of $\$ 9,000,000,000,34$ percent of the United States' exports and 33 percent of her imports. These facts alone, regardless of one's opinion as to immigration restriction, were sufficient to "avoid any unneccessary disturbance" of commercial and diplomatic relations. The termination of this special relationship between New World nations would benefit certain European countries which eagerly anticipated such an estrangement..$^{52}$

Certainly the reactions of Mexican leaders to congressional proposals bore out the worst fears of Kellogg and Hoover. Editorial opinions interpreted the proposed quota as a gross insult and a direct threat to amicable relations. For years, a writer on the staff of El Universal wrote, braceros from south of the border had been eagerly received by employers who used the migrant laborers to feather their own nests with profits and develop the economic infrastructure of their country. Suddenly, without rational cause, politicians had decided to label Mexicans as "undesirable," a threat to the nation they 
had helped build. In a more emotion-laden tone an article in Excelsior attacked the Box bill as an excellent measure of American racism. How, the writer asked, could the much-heralded spirit of friendship exist between the two countries when things like that were allowed to happen in Washington? President Emilio Portes Gil announced that he would view any quota law as totally unjustified and an indignity to the Mexican people. Other government spokesmen announced that they were studying the advisability of sending a formal note of protest. ${ }^{53}$

Privately, Mexican officials told Ambassador Morrow that his government should and must frustrate restrictionist sentiments. They told him that they had no plans to lower emigration because of the many benefits which accrued to Mexico from it. If the Coolidge administration could not do this to foster international goodwill, Americans should give serious thought to the amount of money they had invested in Mexico: if Mexicans were indeed inferior, there was then no reason to put investments into their native land ${ }^{54}$

There had to be some political compromise for this problem. Most proponents of the quota were motivated by a narrow bigotry which was clearly reflected in their proposed legislation. These ideas of racial purity and nationalism were a blatant affront to Mexican leaders and unacceptable to most members of the executive branch of the United States government. But these ideas were also too popular, too well believed in the 1920s to be ignored. Some policy had to be formulated which would serve a twofold purpose: to assuage nativist feelings and mitigate national suspicions in Mexico. The Department of State proved to be the logical bureaucratic arm of the government to effect this compromise.

Kellogg relied extensively on administrative measures to prove to congressmen that there was no need for a quota. The Secretary accepted the plan of Monnett B. Davis, Chief of the Visa Office, to solve the problem. Davis suggested the rigorous application of existing laws by consular officers when they processed requests to enter the United States legally; consuls must end immediately their more than liberal interpretation of rulings and laws which might exclude braceros. Instead, there must be a zealous denial of applications based on the "likely to become a public charge" provision of the law of 1917. In addition, the number of officers in the Border Patrol should be increased, and they should turn their attention to illegal entrants so that the number of aliens turned back at the border and deported from interior areas would greatly increase. All of these actions would vitiate attempts to legislate an arbitrary quota. Employers and possibly the Mexican government might complain, Davis concluded, but this was the path to be taken if a harsher outcome was to be avoided..$^{55}$

Kellogg accepted this proposal and ordered consuls to go beyond Davis' suggestions. He believed that Mexico could not object to this attitude as it 
was not singled out for special treatment: the new policies were merely applying existing law. In addition to Davis' suggestion of the application of the "likely to become a public charge" clause, Kellogg told diplomatic officers to reject applications on grounds of illiteracy and the prior contract proscription of the law of 1885 . Thus, illiterate peones and campesinos had their requests rejected outright, and when they said they had a job waiting in the United States the application was rejected because of the contract labor law. If the worker had no money and no job waiting, his application was denied on the grounds that he was a possible charity case. The new policy began in August 1928 and by December 1929 the number of visas granted had fallen dramatically. Consuls issued 832 permits to cross the border in the latter month compared to about 3,000 in December of the preceeding year. The Department of State gave full publicity to its curtailment of the number of legal immigrants, and, in the opinion of John Simmons, Chief of the Visa Office after Davis, had dampened "the ardor of the most rabid advocates of the quota. $"{ }_{56}$

Other administrative actions helped to decrease the number of illegal aliens in the United States. The Border Patrol was increased in size to allow it more men to prevent illegal entries. A deportation drive sent thousands of workers back to Mexico. By the early part of 1929 corporations began to complain that they suffered from acute shortages of labor. Contracting agencies found it more difficult to induce immigration. All their pleas for another formal exemption from federal legislation fell on deaf ears. American consuls reported that they were quite pleased with these aftereffects of their efforts. The success in curbing Mexican immigration even elicited a letter of praise from Albert Johnson to President Hoover. ${ }^{57}$

In Mexico City, as Hoover and Kellogg had hoped, there was no wave of hysteria against the actions of the American government. For many years revolutionary leaders had publicly expressed their desire that nationals stay home to aid Mexican reconstruction. The United States' administrative restrictions accomplished this end, and, in any event, it was an open secret that illegal immigration continued, although on a smaller scale. The labor exodus went on, along with the benefits it provided for Mexico, and Mexican governments praised Kellogg's policy. There had been no special quota act, the American authorities were simply exercising their unquestioned right to implement their legislative mandate, and the deportees had indeed violated the laws of their host country. The only request that the latter action elicited from the Mexican government was that great numbers of braceros not be deported at the same time and point on the border. If this were done, it would create the insoluble problem of feeding and transporting large numbers of nationals. ${ }^{58}$

Hoover and Kellogg simultaneously took steps on the floor of congress to defeat the restrictionists. In late 1928 allies of the administration introduced a 
bill in the House and Senate making it a felony to enter the United States in contravention of immigration laws. The bill stipulated a prison term of up to two years and a fine of $\$ 1,000$ for those convicted of illegal entry. Opponents of the quota supported the measure as an effort to assuage the strong nativist desire for stringent laws and to tighten up on immigration without making specific mention of Mexico. The bill rapidly gained approval in both chambers and with Hoover's signature became law on March 4, 1929. ${ }^{59}$

Hoover also did what he could to ensure an ample supply of laborers for southwestern employers. He did this by sponsoring the Registry of Aliens Act. This law's provisions stipulated that any illegally resident alien who had resided in the United States continuously prior to June 3, 1921, and was of good character could legalize his status upon presenting proof he met these requirements. This bill was signed by President Coolidge on March 2, 1929, with the urging of President-elect Hoover. Pro-quota forces had not been able to garner enough votes in the House or Senate to present any serious opposition. Hoover's intention to help employers bore fruit quickly. The President ordered Commissioner Hull in April 1929 to issue the following guidelines to satisfy the law's provisions: the only evidence needed was a sworn statement of two credible citizens that the alien's claims were true. Immediately, chambers of commerce and employer groups mounted extensive campaigns to inform braceros of their rights and induce them not to return to Mexico. Mexican consuls aided in this drive to legalize their fellow nationals' stay abroad. According to Richard Boyce, the American consul at Nuevo Laredo, thousands of illegal aliens, often on quite suspicious evidence, were thus allowed to remain in the United States and pursue their former course of employment. ${ }^{60}$

Hoover and his allies were most effective in directing and aiding the strategy of anti-quota forces in both the House and the Senate. Through a series of political deals and threats of executive disfavor for pet projects, advocates of a quota had only one favorable vote on their proposals in the period from 1926 to 1930. In fact, Johnson's Committee on Immigration and Naturalization never did get a restrictionist bill to the floor of the House; in the Senate the Immigration Committee reported favorably on a quota bill in 1928 , but no debate or action on the floor took place. In May 1930 the pro-quota forces reached the zenith of their success when the Senate passed the Harris bill by a vote of fifty-six to eleven. An analysis of this vote shows that even some senators from the far West voted for the measure. Hoover and his spokesmen had perhaps lobbied too hard for Pan Americanism and given rise to an intense feeling of nationalism. Many in the Senate felt as did Senator Heflin of Alabama when he said the right and power "to do what we feel best for our country regarding immigration constitute the thing necessary to preserve free government in America. ${ }^{61}$ 
Hoover then turned his attention to possible House action on the bill approved by the Senate. He publicly threatened to veto the measure if the House passed it once it had become evident that members of the lower chamber shared the intense national feelings of the Senate. Hoover's most decisive effort, however, was to pressure the all-powerful Rules Committee to block the bill from coming to the floor for a vote. In June 1930 the session ended without debate of the Harris bill. A restrictionist proposal had been defeated for the first time since 1882, and Congress turned its attention to other, more pressing matters of concern to the United States.$^{62}$

Immigration probably would have continued in its unregulated form if it had not been for this intense opposition to it. The outcry of nativists forced the Coolidge and Hoover administrations to decrease the number of braceros who legally entered the United States and to reveal the motivations behind their policy. Republican leaders had little love for the bracero. They made no pretense, or even mention, of Mexicans assimilating and becoming good citizens. Most officials, including Hoover, believed it right and proper for their country to restrict non-Nordic immigration if the issue was considered strictly within the purview of domestic policy. Of paramount importance, however, was the purpose braceros served for the foreign interests of the United States. Trade and investments could not increase in Latin America if Mexicans were maltreated as a matter of official governmental policy. This acid test of goodwill had to be-and was-successfully passed.

The administration's allies in the quota battle had decidedly mixed motivations. The missionaries' praise of the Mexicans' strengths and potential was not taken seriously by many people. The hearts and minds of the vast majority of the American people were not amenable to these suggestions in the 1920s. Many years would pass before the merit of the Protestants' arguments received the serious consideration they deserved. One reason for this failure was that missionaries misinterpreted the import of the Revolution of 1910. It was indeed a sharp break with the past in many ways, but the model sought by revolutionaries was a Mexican one, not the American-Protestant course of development. Employers of bracero labor were smack in the mainstream of popular thought when they argued the inferiority of their employees. If anything, they tried to "out nativist" the nativists to show that the Mexicans were so low in the scale of human development that they presented few of the dangers which had given rise to the law of 1924. This racist posture was frankly designed to help fill the void in manpower caused by the restrictionist laws of 1917, 1921, and 1924. This anti-Mexican posture was loudly proclaimed as long as immigration functioned to service the profits and investments of farmers and industrialists.

Restrictionists lost their battle in the latter part of the decade not because they lacked popular support, but because they did not have the leverage in 
Congress to pass their proposals. The alliance of most western representatives, administration officials, employers, and missionaries saw to it that only one bill passed the Senate in 1930. In the House, this bill never got to the floor for debate. This congruence of interests, often for radically different motives, allowed a small minority in the country to defeat the will of the majority. The federal government in particular showed itself to be politically astute when it lowered legal immigration in order to provide itself with an additional argument against the proposed quota. Just as legislative attempts waned, the depression of the 1930s, not new national laws, brought about all the nativists had hoped for and more. 


\section{8}

\section{The Great Depression: Emigration Halts and Repatriation Begins}

Emigration ended soon after the onset of the Great Depression in October 1929. Industrial and agricultural production slumped and their by-product of high unemployment caused very harsh conditions for braceros. The sudden surplus of labor filled the vacuum into which Mexicans had flocked since the turn of the century, and employers gave preference to American citizens for work that was available. There was no longer any need for Mexican laborers. As if massive layoffs did not inflict enough misery on the bracero community, agencies in all levels of government actively promoted repatriation for the formerly much-sought immigrants. The presence of the latter in the 1920s and before had been vociferously supported as a plus in the profit column of business enterprises, but by 1930 braceros formed only an additional drain on an already hard-pressed nation. It was widely believed that Americans owed little to Mexicans, that the best solution for all concerned was to send them back to their homeland. The volume of forced and voluntary repatriation peaked in 1931; by 1935 as many as 500,000 braceros-about one-half of those in the United States-may have returned to Mexico. These developments laid bare the failures of revolutionary governments during the preceding decade and showed again with renewed vigor the near-total control exercised over emigration by American attitudes and institutions. The disaster which Obregón had tried to deal with in 1921 and 1922 seemed mild in comparison to what confronted Presidents Emilio Portes Gil (1928-29) and Pascual Ortiz Rubio (1929-32).

The intensity of the downturn which began in late 1929 brought unparalleled economic paralysis to the United States. By January 1930 over $3,000,000$ workers had lost their jobs; by the end of the year the number of 
unemployed had doubled to $6,000,000$. In December 1932 the number of those without work was conservatively estimated at more than $11,000,000$. The lack of internal and external markets for industrial and agricultural products brought about a drastic drop in incomes for workers and their employers: factory wages plummeted from $\$ 12$ billion in 1929 to $\$ 7$ billion in 1932; farm income more than halved during the same period, falling from $\$ 12$ billion to $\$ 5$ billion. ${ }^{1}$

Mexican workers suffered disproportionately from this situation. At the urging of local, state, and federal spokesmen in early 1930, local employers laid off most of their bracero employees in order to give their jobs to American citizens. In Detroit, for example, the auto industry and most local, smaller businesses responded with wholesale layoffs of Mexicans; in New York City similar conditions of sudden, massive unemployment faced the immigrants. In most urban areas located far from the border the braceros' lack of income quickly resulted in misery. In Chicago, Gary, Toledo, and Bethlehem the slowdown in the iron and steel industries alone caused one out of every ten Mexicans to lose his job. Another 15 percent were thrown out of work by the disintegration of the construction industry. Charitable resources when available, offered only paltry amounts of money; many city and county welfare bureaus refused to give assistance to Mexicans or blacks so as to have at their disposal more money for unemployed whites. ${ }^{2}$

Similar conditions prevailed in the Southwest with its heavy concentrations of Mexican laborers. In late 1931 consular inspector Enrique A. González visited seventeen districts in order to assess the impact of the depression there. The conditions he found typified the disaster that had befallen braceros. In Phoenix 6,400 Mexican laborers out of a total of 45,000 had voluntarily returned to their native land. Many repatriated themselves at the insistence of local charity officials and employers. In San Bernardino, California, 5,200 braceros had been sent home out of a total population of 50,000 . The Chamber of Commerce and elected officials strongly pressured employers to fire all of their foreign workers - and were largely successful in their campaign. González found that unemployment among those Mexicans who had remained in the United States ranged from 20 to 50 percent, with the latter percentage being the most common. ${ }^{3}$

Corridos of the braceros evinced shock and dismay at these sudden reversals and expressed in more human terms the hard times. One balladeer lamented the lowered living standards in the following terms:

In these unhappy times depression still pursues us; lots of prickly pear is eaten for lack of other food. 
Probably everybody knows

about the many evils;

that there are homes without food, in which our children cry.

Some lose their houses because they can't pay rent; the fortunes have collapsed of some who lived in them.

No light is seen in the houses nor does water flow from the tap; the people are in tatters and in a deplorable state.

This sharp crisis

is defying the world; if you have nothing to eat don 't cry, keep on fasting.

And so I take my leave, may you be happy.

Here ends the song, but the depression goes on forever. ${ }^{4}$

The federal government helped where it could to rid the country of Mexicans. With huge labor surplus at hand, there was no need for the bracero. Latin American nations must accept the policy of the United States as it was designed merely to provide for its own citizens. There was no singling out of the bracero: all immigrants were deported if they were found to be in the country in defiance of the law. This campaign was vigorously supported by newspaper editorials. The San Francisco Call Bulletin, for example, urged Uncle Sam to rid the nation of undesirable elements. Aliens were said to prey on citizens by taking their jobs and money. Massive deportations were suggested as an easy way to spread out available employment opportunities.5

Nativists eagerly went along with this new policy. Charles Visel of Los Angeles thanked federal immigration authorities for their "efficiency, ag- 
gressiveness and resourcefulness" in searching for and deporting Mexicans who had broken some law in the United States. The Los Angeles Chamber of Commerce called for an even more effective deportation drive and even offered to pay the cost of passage back to the border. Members of the Chamber also "planted" stories in local newspapers and started a whispering campaign to the effect that all foreigners were to be deported. This tactic was carried out in collusion with immigration officials and resulted in large numbers of voluntary repatriates. ${ }^{6}$

The following ballad indicates some of the many minor infractions of local laws which could lead to deportation during this time:

If you are not legally married, a passport is of no use to you; the county authorities will take you to sleep there in the jail.

They take away the single women, and sometimes those who are not; poor little poppies cut down by the Border Patrol.

If you used to make beer and still operate a still, just scratch your head and don't admit anything. ${ }^{\text {? }}$

Mexicans who took advantage of local welfare resources became targets for deportation also. Instead of indefinitely supporting bracero families, charity officials figured it would be cheaper to mount repatriation drives. A contemporary observer estimated that the average cost of transporting a family from Los Angeles to the border amounted to $\$ 71.14$. One trainload of returnees-a total of 6,024 people-cost Los Angeles county only $\$ 77,249.25$. Had this group remained where they were the county would have had to spend $\$ 424,933.70$ to maintain them for one year. In many cities far from the border these local campaigns almost erased the Mexican presence in the early 1930 s. Mexican consuls were usually advised of impending repatriations, and they saw to it that once the families were back in Mexico railroad transportation was arranged to take them back to their native villages. ${ }^{8}$

The largest number of Mexicans, over 124,000, crossed back into Mexico in the year 1931 , and by 1935 about 500,000 braceros had gone back 
to their native land. The voluntary and forced return of so many people spread the news of lack of employment and unfriendly receptions in the United States. The clear message to would-be emigrants was to stay at home. By early 1932 these new circumstances had reduced emigration to a trickle of its former strength. At the most, only a few thousand braceros crossed the border in search of work by 1932. The negative forces of economics and American attitudes had brought about an end to the northward flow of population. The fate inflicted upon the workers quickly removed them from public consciousness in the United States. Federal officials along the border did not even bother to count the number of repatriates with any precision. Missionaries regretted the loss of potential converts but were helpless to do anything about it. President Hoover and his government turned attention to the more pressing problem of national economic reconstruction. For the time being, the bracero would stay in Mexico. ${ }^{9}$

Mexican policymakers and bureaucrats were totally unprepared for what confronted them. They, like their American counterparts, were unaware of the intensity of the economic downturn until it was an established fact. As discussed earlier, there had been a lack of planning and an absence of funds to prepare for such an eventuality. In addition to being unprepared, the revolutionaries were trapped in their own rhetoric: for years they had proclaimed to their nation an ardent desire to see all the braceros back home where they belonged; once the return migration began, in accordance with the letter of the law of the host nation, they could not decry the repatriation. Or, at least, they could not do so in public. Privately, consuls were admonished to do all in their power to keep as many workers in the United States as possible. The reception which awaited those who returned was as unsatisfactory as the government's attempts to control the exodus in the first place. ${ }^{10}$

Diplomatic representatives in the United States did what they could to finance and facilitate the return of their co-nationals. Francisco Pesquiera, the consul responsible for San Bernardino, California, turned to the self-help groups he and others had tried to nurture throughout the 1920 s. The Beneficencia Mexicana dipped into its treasury and purchased railroad tickets for about 50 repatriates. This minimal aid exhausted the finances of the workers' group which, in any event, folded up soon thereafter as most of its associates lost their jobs. In Los Angeles the consul received over 15,000 requests for aid from the unemployed, but he could not coax enough money from Blue Cross and Honorary Commission groups to aid more than a handful of people. In response to urgent requests for help from consuls, the Secretary of Foreign Relations cautioned that there was not one peso available for the succor of braceros in the United States. This lack of money meant that American sources must be looked to during the crisis. ${ }^{11}$

Consuls cooperated to the fullest with charity bureaus which carried out repatriation drives. In southern California, the area of the most intensive 
campaigns to get rid of Mexican workers, consuls explained the procedures to be used in sending local braceros back to their homeland, and frequently rode with the returnees to the border. There the consuls expedited the necessary paperwork with officials in the Mexican Department of Migration. The role of the diplomats apparently had a markedly calming effect on the workers. Consul Ricardo Hill of Los Angeles extended so much help to county repatriation officer Philip Robinson that Robinson commended his "very valuable assistance" in shipping his countrymen home. ${ }^{12}$

Consular aid to the repatriate caravan from Karnes City, Texas, is illustrative of the imaginative use of resources by diplomats. In September 1931 Consul Alejandro Martínez of Laredo received doleful news of the condition of the Mexican colony in Karnes City. About 800 families, a total of 4,000 people, were without work and had been refused aid by local charity sources. Collecting whatever vehicles they could lay their hands on, the braceros set off for Nuevo Laredo, Tamaulipas, across the border from Laredo where Martínez was stationed. Martínez was instructed by Consul General Eduardo Hernández to obtain whatever aid he could for the people heading his way. Martínez collected about $\$ 200.00$ from Blue Cross and Honorary Commission groups in Laredo, Brownsville, and San Antonio, and used the money to purchase food and gas for the repatriates and their 110 vehicles. He telegraphed the Mexican colonies in San Benito and Harlingen, Texas, seeking whatever aid those groups could provide. Merchants in San Antonio were asked for, and gave, 1,000 packages of food. When the caravan arrived at Laredo on October 28,1931 , and now reduced to 1,612 people, the consul had their entry permits all arranged and had secured a train to take them to the interior of Mexico. ${ }^{13}$

In other cases consuls made vigorous protests when instances of the ill treatment of braceros came to their attention. During the Border Patrol's careful screening of immigrants to ascertain possible deportees, many complaints were made by Mexicans that they were rudely handled and spoken to in a demeaning manner. Consuls lodged formal protests with the officers in question and asked that similar occurrences should not happen again. If this course of action did not result in satisfactory results, the Mexican Ambassador in Washington took up the matter with proper officials there. Another source of hardship for the repatriate was found when a deportation drive placed many of them at the border at one time and without sufficient warning to Mexican officials. Consuls, in league with their Ambassador, announced that they expected to be notified well in advance of the plans so that they could make proper arrangements to care for the repatriates once they had crossed into Mexico. ${ }^{14}$

The Mexican government assumed responsibility for the braceros and their families once they were out of the United States. Migration officials were ordered to do everything possible to facilitate the workers' return. Only an 
oral declaration was needed to establish nationality; no customs duties were levied upon goods brought into the country. Personnel of Mexican national railroads were to charge a minimal amount of money to carry the repatriates back to their native villages. The government had no program beyond these measures. As late as 1933 the Secretary of Foreign Relations and the Secretary of Interior had failed to formulate a workable plan to return the workers to a productive life in their homeland. All the schemes and hopes of the 1920s had come to naught. ${ }^{15}$

At best, returning workers faced very difficult conditions. When they arrived in Mexican border towns they usually had no money or food with them. Their government, pleading lack of funds, was unable to provide food, shelter, clothing, or needed medical care. On many occasions inhabitants of these cities had to sponser dances and other fund-raising functions in order to provide minimal amounts for their fellow citizens. Migration and railroad employees took advantage of the situation and tried to extort money from the hapless migrants. At one point B. V. Curry, head of the Los Angeles county welfare bureau, complained to the local consul about conditions in Cuidad Juárez. Curry said that red tape forced repatriates to wait four or five days for transportation back to the central plateau. In many cases the delay was caused by the returning families' inability to meet demands for small bribes made by railroad workers and migration inspectors. Other consuls filed similar complaints to the Secretary of Foreign Relations but the persistence of such reports indicates the problems were not alleviated. ${ }^{16}$

Nor was a new and better life found upon the repatriates' return to their native villages. Most found it very difficult to make the necessary adjustments. They had become used to the higher wages and better standard of living in the United States. One student of the repatriation movement talked to more than 100 returned Mexicans in the states of Michoacán and Guanajuato and quickly learned of their disillusion: "I don't like it here. You can't make a living. I want to go back there [to the United States]." Another typical complaint was that "in Los Angeles I always had some money in my pocket .... Here we are always broke." Others complained of the suspicion and ill treatment manifested by neighbors who had not emigrated. ${ }^{17}$

The following characterization of the repatriates proved to be all too typical:

I shall sing you a song of all who were deported, who came back speaking English from those wretches. 
They lop off their mustaches

and chew their tobacco;

it seems the thing to do

and they don't have a cent.

They cut their hair close

like a clipped donkey;

they go to second-hand stores

and buy worn-out clothes. ${ }^{18}$

Thus ended the braceros' sojourn. He was rejected by those in the United States who no longer had need of his labor and was sent back to his homeland. The castigations and lamentations of the workers and their fellow Mexicans clearly show the continuing lack of control exercised by revolutionary leaders. They could only respond to the situation as it developed. They lacked funds, bureaucracy, and planning, just as had Obregón. The decade ended as it had begun. 



\section{Notes}

\section{ABBREVIATIONS}

AHSRE

Calles papers

Calles papers, Series A

Carranza papers

Coolidge papers

DHRM

Harding papers

Hoover papers

Obregón papers

Obregón papers, Series A

Ortiz Rubio papers

Portes Gil papers

RG 59, $150 \ldots$
Archivo Histórico de la Secretaría de Relaciones Exteriores, Mexico City, file IV/524. File IV/524 deals with emigration matters.

Archivo General de la Nación, Papeles Presidenciales de Plutarco Elias Calles, Mexico City.

Archivo General de la Nación, Papeles Presidenciales de Plutarco Elías Calles, Serie A, Mexico City. Documents in this series have no file number.

Archivo Carranza, Fundación Cultural de Condumex, S.A., Mexico City. Items in this collection have no classification numbers and are arranged only in chronological order.

Library of Congress microfilm edition of the Calvin Coolidge papers.

Documentos históricos de la Revolución mexicana (Mexico: various publishers, 1964-76).

Warren G. Harding papers, Ohio Historical Society (microfilm edition).

Herbert Hoover collection, Hoover Library, National Archives and Records Service, West Branch, Iowa.

Archivo General de la Nación, Papeles Presidenciales de Álvaro Obregón, Mexico City.

Archivo General de la Nación, Papeles Presidenciales de Álvaro Obregón, Serie A, Mexico City. Documents in this series have no file number.

Archivo General de la Nación, Papeles Presidenciales de Pascual Ortiz Rubio, Mexico City.

Archivo General de la Nación, Papeles Presidenciales de Emilio Portes Gil, Mexico City.

General Records of the Department of State, Visa Division, Correspondence Regarding Immigration, 1910-1939, National Archives, Record Group 59, Washington, D.C. 
RG 59,811 . .

RG 59, $811 \ldots$

Mexico/ ...

RG 59, $812 \ldots$

RG 85

RG $85,812 \ldots$
Department of State Decimal File, 1910-1929, National Archives, Record Group 59, Washington, D.C.

General Records of the Department of State, Visa Division, General Visa Correspondence, 1914-1940, National Archives, Record Group 59, Washington, D.C.

Records of the Department of State Relating to the Internal Affairs of Mexico, 1910-1929, National Archives, Record Group 59, Washington, D.C.

Records of the Immigration and Naturalization Service, National Archives, Record Group 85, Washington, D.C.

Immigration and Naturalization Service, Central Office, Subject Correspondence, 1906-1932, National Archives, Record Group 85, Washington, D.C.

\section{CHAPTER 1}

1. Jorge Tamayo, Geografia general de México, 2 vols. (Mexico: Talleres Gráficos de la Nación, 1949); Carlos Díaz Dufoo, México y los capitales extranjeros (Mexico: Librería de la Vda. de Ch. Bouret, 1918), p. 167; Nathan Whetten, Rural Mexico (Chicago: University of Chicago Press, 1948), pp. 137, 576; Sumner Cushing, "The Distribution of Population in Mexico," Geographical Review 2 (April 1921): 227-42.

2. Walter Weyl, "Labor Conditions in Mexico." Bulletin of the Department of Labor 38 (January 1902): 32-33; Luis González y González et al., La República restaurada: La vida social, vol. 3 of Historia moderna de México, ed. Daniel Cosío Villegas (Mexico: Editorial Hermes, 1956), p. 168; Brantz Mayer, Mexico: Aztec, Spanish and Republican 2 vols. (Hartford: S. Drake \& Co., 1853), vol. 2, p. 30.

3. Mayer, Mexico, vol. 2, p. 31; González y González et al., La República restaurada: La vida social, pp. 168-69, 243, 319. González y González, pp. 149-369, summarize rural conditions on the eve of the Porfiriato.

4. Quoted in Eyler Simpson, The Ejido, Mexico's Way Out (Chapel Hill: University of North Carolina Press, 1937), p. 39.

5. Speech of December 3, 1912, in Diego Arenas Guzmán (ed.), Historia de la Cámara de Diputados de la XXVI Legislatura Federal 4 vols. (Mexico: Talleres Gráficos de la Nación, 1963), vol. 3, pp. 376 (quote), 371-80; Moisés González Navarro, La vida social en el Porfiriato, vol. 4 of Historia moderna de México (Mexico: Editorial Hermes, 1957), p. 217. The money conversion rate from 1900 to 1931 was two pesos for one United States dollar: México, Secretaria de la Presidencia y Nacional Financiera, 50 años de la Revolución mexicana en cifras (Mexico: Editorial Cultura, 1963), p. 115. Hereafter all money will be given in U.S. dollars unless otherwise noted.

6. Andrés Molina Enríquez, Los grandes problemas nacionales (Mexico: Instituto Nacional de la Juventud Mexicana, 1964), pp. 106-07.

7. Friedrich Katz, "Labor Conditions on Haciendas in Porfirian Mexico: Some Trends and Tendencies," Hispanic American Historical Review 54 (February 1974): 25-26 (quote), 24-26.

8. Manuel Gamio, The Mexican Immigrant: His Life Story (Chicago: University of Chicago Press, 1931), pp. 149-50. 
9. González Navarro, La vida social, p. 72; Weyl, "Labor Conditions in Mexico," pp. 68-69.

10. Luis Cossío Silva, "La agricultura," vol. 7, pt. 1 of Historia moderna de México (Mexico: Editorial Hermes, 1965), pp. 5, 10, 16-17.

11. Gamio, The Mexican Immigrant, p. 92.

12. Lesley Byrd Simpson, Many Mexicos, 3rd ed. (Berkeley: University of California Press, 1966), pp. 11-19; Weyl, “Labor Conditions in Mexico," pp. 66-68.

13. Molina Enríquez, Los grandes problemas, p. 108.

14. Weyl, "Labor Conditions in Mexico," p. 82 (quote); José Covarrubias, Algunas observaciones acerca de la inmigración y de la colonización en las naciones independientes de América (Mexico: Secretaría de Fomento, 1906), pp. 14, 149, passim.

15. George McBride, The Land Systems of Mexico (New York: American Geographical Society, 1923), pp. 75-76; Simpson, The Ejido, p. 29; Wistano Luis Orozco, Los ejidos de los pueblos (Mexico: Ediciones El Caballito, 1975 [1914], pp. 191-93.

16. Simpson, The Ejido, p. 28.

17. McBride, The Land Systems of Mexico, p. 155; John Womack, Zapata and the Mexican Revolution (New York: Vintage Books, 1970), pp. 42-47.

18. Paul Friedrich, Agrarian Revolt in a Mexican Village (Englewood Cliffs: Prentice-Hall, 1970), pp. 1-49.

19. Ibid., pp. $45-46,144$.

20. Manuel Gamio, Introducción, sintesis y conclusiones de la obra La población del Valle de Teotihuacán (Mexico: Secretaría de Educación Pública, 1922), pp. 14, 19; Manuel Gamio et al., La población del Valle de Teotihuacán 3 vols. (Mexico: Secretaría de Educación Pública, 1922).

21. Gamio et al., La población del Valle de Teotihuacán, vol. 1, p. xviii; vol. 2, pp. 585-86.

22. Molina Enríquez, Los grandes problemas, pp. 145-46; John M. Hart, Anarchism \& the Mexican Working Classes, 1860-1931 (Austin: University of Texas Press, 1978), pp. 61-3, 86.

23. González Navarro, La vida social, pp. 19-20; Clark Reynolds, The Mexican Economy (New Haven: Yale University Press, 1970), pp. 20-21.

24. Gamio, The Mexican Immigrant, p. 45 (quote); Lucio Mendieta y Núñez, El problema agrario de México 7th ed. (Mexico: Porrua, 1959), p. 117; Jean Meyer, Problemas campesinos y revueltas agrarias 1821-1910 (Mexico: SepSetentas, 1973), pp. 222-23; Frank Tannenbaum, The Mexican Agrarian Revolution (New York: Archon Books, 1968 [1929]), pp. 74-90.

25. International Bureau of American Republics, Mexico (Washington: GPO, 1904), passim; Revista Mercantil, "Cuadro estadístico de varias mercancias extractado de nuestra Revista 'Mercantil" (Guadalajara: n.p., 1911); Jan Bazant, Cinco haciendas mexicanas: tres siglos de vida rural en San Luis Potosí, 1600-1910 (Mexico: Colegio de México, 1975), pp. 172-78; Cumberland, Mexico, p. 224; Weyl, "Labor Conditions in Mexico," pp. 57-58, 70 (first quote); Molina Enríquez, Los grandes problemas, p. 260 (second quote). 
26. Quoted in Moisés Gonzalaz Navarro, La colonización en México, 1877-1910 (Mexico: Colegio de México, 1960), pp. 20-21.

27. Antonio Manero, El antiguo regimen y la revolucion (Mexico: Tipografía y Litografía 'La Europea," 1911), pp. 211-13; Reynolds, The Mexican Economy, pp. 23-26; Rodney D. Anderson, Outcasts in Their Own Land: Mexican Industrial Workers, 1906-1911 (DeKalb: Northern Illinois University Press, 1976), pp. 216-17.

28. Francisco Calderón, La vida económica, vol. 2 of Historia moderna de México (Mexico: Editorial Hermes, 1957), pp. 282-89; Oscar J. Martínez, Border Boom Town: Ciudad Juárez Since 1848 (Austin: University of Texas Press, 1978), pp. 15-17, 27-31, traces the development of the free zone.

29. U.S. Bureau of Commerce, Highways of Commerce (Washington: GPO, 1895), pp. 44, 48; Bernard Moses, The Railway Revolution in Mexico (San Francisco: The Berkeley Press, 1895), pp. 46-47; John Coatsworth, "Railroads, Landholding, and Agrarian Protest in the Early Porfiriato," Hispanic American Historical Review 54 (February 1974): 48-71.

30. Francisco Calderón, "Los ferrocarriles," vol. 7, pt. 1 of Historia moderna de México, pp. 483-634; Matías Romero, Mexico and the United States (New York: Knickerbocker Press, 1898), pp. 115-19. Sources for the maps are Map 1: Calderón, "Los ferrocarriles," p. 515; Map 2: Ibid., passim; Map 3: American Heritage Publishing Company, The American Heritage Historical Atlas (New York: American Heritage, 1966), pp. 254-55.

31. Eric Wolf, Peasant Wars of the Twentieth Century (New York: Harper \& Row, 1969), pp. 20-21 (quote); U.S. Senate, Committee on Foreign Relations, 66th Congress, 2nd Session, Investigation of Mexican Affairs, 2 vols. (Washington: GPO, 1920), vol. 2, pp. 201-202; U.S. Bureau of Commerce, Commercial Relations of the U.S. with Foreign Countries During the Year 1898, 2 vols. (Washington: GPO, 1899), vol. 1, p. 566; Katz, "Labor Conditions on Haciendas in Porfirian Mexico," pp. 32-34.

32. Clarence Senior, Land Reform and Democracy (Gainesville: University of Florida Press, 1958), p. 56; González Navarro, La vida social, p. 147; U.S. Bureau of Commerce, Commercial Relations of the U.S. with Foreign Countries During the Years 1890 and 1889 (Washington: GPO, 1892), pp. 495-97; Moses, The Railway Revolution in Mexico, pp. 76-78, 84-85; Martínez, Border Boom Town, pp. 19-25.

33. U.S. Bureau of Commerce, Commercial Relations ... 1898, vol. 1, pp. 571, 582; Guadalupe Nava Oteo, "La minería," vol. 7, pt. 1 of Historia moderna de México, pp. 249-50.

34. U.S. Bureau of Commerce, Commercial Relations ... 1898, vol. 1, p. 566; Weyl, "Labor Conditions in Mexico,"' p. 55; Colegio de México, Estadísticas económicas, p. 151; Marvin D. Bernstein, The Mexican Mining Industry, 18901950 (Albany: State University of New York Press, 1965), p. 86.

\section{CHAPTER 2}

1. Donald Meinig, Southwest: Three Peoples in Geographical Change, 1600-1970 (New York: Oxford University Press, 1971), pp. 41-42; Orris Herfindahl, "De- 
velopment of the Major Mining Industries in the United States from 1839 to 1909," in National Bureau of Economic Research, Employment and Productivity in the United States After 1800 (New York: Columbia University Press, 1966), p. 316.

2. U.S. Congress, Senate, Report of the United States Immigration Commission, 42 vols. (Washington: GPO, 1911), 61st Congress, 2nd Session, vol. 25, pt. 2, p. 233; Harold Barger and Hans H. Landsberg, American Agriculture, 18991939 (New York: National Bureau of Economic Research, 1942), pp. 90, 334; E. J. Foscue, "Agricultural History of the Lower Rio Grande Valley," Agricultural History 8 (March 1934): 124-37; Bureau of the Census, Abstract of the Twelfth Census of the United States, 1900, 3rd. ed. (Washington: GPO, 1904), pp. 270, 296; idem, Thirteenth Census of the United States, Vol. 5: Agriculture (Washington: GPO, 1913), pp. 692, 829, 845.

3. Varden Fuller, "The Supply of Agricultural Labor in California," report in U.S. Congress, Senate, Hearings Before a Subcommittee of the Committee on Education and Labor, Violations of Free Speech and Rights of Labor (Washington: GPO, 1940), pp. 19,778, 19,883.

4. Carey McWilliams, Factories in the Fields (Boston: Little, Brown, 1939), passim.

5. Mary Roberts Coolidge, Chinese Immigration (New York: Arno Press, 1969), pp. 342, 498-500; Stuart Creighton Miller, The Unwelcome Immigrant: The American Image of the Chinese, 1785-1882 (Berkeley: University of California Press, 1969), p. 168 (quote); Yamato Ichihashi, Japanese in the United States (New York: Arno Press, 1969).

6. John Higham, Strangers in the Land: Patterns of American Nativism 1860-1925 (New Brunswick: Rutgers University Press, 1955), p. 4 (quote), passim.

7. Higham, Strangers in the Land, pp. 24-26; Cecil Robinson, With the Ears of Strangers: The Mexican in American Literature (Tucson: University of Arizona Press, 1963), pp. 135-51; Stanton Davis Kirkham, Mexican Trails: A Record of Travel in Mexico, 1904-07, and a Glimpse at the Life of the Mexican Indian (New York: G. P. Putnam's Sons, 1911), pp. 10-11; Victor Clark, "Mexican Labor in the United States," Bulletin (United States Bureau of Labor) 78 (September 1908): 512.

8. Clark, "Mexican Labor in the United States," p. 496; Report of the United States Immigration Commission, vol. 25, pt. 2, p. 110; Justin H. Smith, The War With Mexico, 2 vols. (New York: The Macmillan Co., 1919), vol. 2, p. 125 (quotes); John R. Commons, Races and Immigrants in America (New York: The Macmillan Co., 1907), pp. 6-7, 132; Edward A. Ross, "The Causes of Race Superiority," Annals (American Academy of Political and Social Sciences) 18 (July 1901): 67-89; Marvin Bernstein, The Rise of Anthropological Theory (New York: Thomas Y. Crowell Company, 1968), p. 140.

9. Clark, "Mexican Labor in the United States," pp. 466, 505.

10. Fuller, "The Supply of Agricultural Labor in California," p. 19,861 (quote); Clark, "Mexican Labor in the United States," pp. 491, 511-12; Commons, Races and Immigrants in America, p. 132; Report of the United States Immigration Commission, vol. 25, pt. 2, p. 22; Mario T. García, "Americanization and the Mexican Immigrant, 1880-1930,' The Journal of Ethnic Studies, 6 (Summer, 1978), pp. 19-20, 25. 
11. Barger and Landsberg, American Agriculture, pp. 201-09; Paul S. Taylor, $A$ Mexican-American Frontier: Nueces County, Texas (Chapel Hill: University of North Carolina Press, 1934), p. 105.

12. Harry Schwartz, Seasonal Farm Labor in the United States (New York: Columbia University Press, 1945), pp. 103-04, 108.

13. Paul S. Taylor, Mexican Labor in the United States: Valley of the South Platte, Colorado, University of California Publications in Economics, VI, number 2 (Berkeley, 1929), p. 99; Report of the United States Immigration Commission, vol. 25, pt. 3, pp. 26-27.

14. Paul S. Taylor, Mexican Labor in the United States: Imperial Valley, California, University of California Publications in Economics, VI, number 1 (Berkeley, 1928), p. 12 (quotes); Fuller, "The Supply of Agricultural Labor in California," p. 19, 893; Gerald Nash, The American West in the Twentieth Century (Englewood Cliffs: Prentice-Hall, 1973), p. 20.

15. Frank C. Pierce, A Brief History of the Lower Rio Grande Valley (Menasha, Wisconsin: Banta Publishing, 1917), pp. 128-239; Martínez, Border Boom Town, pp. $159-63$.

16. Taylor, Nueces County, pp. 84-85, 92, 95; Nash, The American West, pp. 18-43, gives a good overview of the new agriculture in the West.

17. Clark, "Mexican Labor in the United States," pp. 470, 474; Report of the United States Immigration Commission, vol. 25, pt. 2, p. 50; Antonio Lomeli, El Paso consul, to Ignacio Mariscal, Secretary of Foreign Relations, March 7, 1910, (72:73)/18-25-62; Martínez, Border Boom Town, p. 34.

18. Clark, “Mexican Labor in the United States," pp. 477, 487, 496, 519.

19. Paul S. Taylor, A Spanish-American Peasant Community: Arandas in Jalisco, Mexico (Berkeley: University of California Press, 1933), p. 35; Louis and Richard Perry, A History of the Los Angeles Labor Movement (Berkeley: University of California Press, 1963), p. 71; Paul S. Taylor, Mexican Labor in the United States: Chicago and the Calumet Region, University of California Publications in Economics, VII, number 2 (Berkeley, 1932), p. 27; Juan Gómez-Quiñones, "Piedras contra la Luna, México en Aztlán y Aztlán en México: Chicano-Mexican Relations and the Mexican Consulates, 1900-1920," in James W. Wilkie et al. (eds.), Contemporary Mexico: Papers of the IV International Congress of Mexican History (Berkeley: University of California Press, 1976), p. 500; Mario T. Garcia, "Obreros: The Mexican Workers of El Paso, 1900-1920," (Ph.D. dissertation in History, University of California, San Diego, 1975), pp. 89-98.

20. Report of the United States Immigration Commission, vol. 25, pt. 3, pp. 128-31, 190-91, 194; N. Ray and Gladys Gilmore, "Bracero in California," Pacific Historical Review 32 (August 1963): 268.

21. John Peavey, Echoes from the Rio Grande: 1905 to Now (n.p., 1963), p. 185; U.S. Bureau of Commerce, Highways of Commerce, p. 458; U.S. Department of Justice, The Border Patrol (Washington: GPO, 1967), pp. 2-3.

22. Clark, "Mexican Labor in the United States," pp. 471, 476.

23. Ibid. (quotes); Taylor, Nueces County, p. 105.

24. Clark, "Mexican Labor in the United States," pp. 474-75. 
25. Luis d'Olwer et al, La vida económica, vol. 7, pt. 2 of Historia moderna de México, pp. 1067, 1103; U.S. Bureau of Commerce, Commercial Relations ... 1898, vol. 1, p. 115; Marvin Bernstein, The Mexican Mining Industry, 1890-1950 (Albany: State University of New York, 1965), pp. 74-76.

26. Toribio García, Naco consul, to Mariscal, October 18, 1908, AHSRE, 12-5-79; Report of the United States Immigration Commission, vol. 25, pt. 3, p. 25.

27. El País, October 22, 1901; ibid., April 1 and May 8, 1906; ibid., October 30, 1907; El Comercio, July 1, 1906, clipping in AHSRE, 18-24-134; México Internacional, June 13, 1909, in Isidro Fabela et al. (eds.), DHRM, 11, p. 167.

28. El País, October 20 and December 14, 1907; ibid., January 20, 1909.

29. Oscar J. Braniff, Observaciones sobre el fomento agricola (Mexico: Imprenta Lacaud, 1910), in Jesús Silva Herzog (ed.), La cuestión de la tierra, 4 vols. (Mexico: Instituto de Investigaciones Económicas, 1960-1962, vol. 1, p. 64; Romulo Escobar, "Indicaciones relativas a colonización," Boletín (la Secretaría de Fomento), 1911, ibid., p. 316; González Navarro, La colonización en México, p. 123.

30. DHRM, 10, pp. 49, 54, 61 (first quote); Jesús Silva Herzog, El agrarismo mexicano y la reforma agraria, 2nd ed. (Mexico: Fondo de Cultura Económica, 1959), pp. 156-57 (second quote).

31. El Imparcial, August 30, 1905; ibid., November 10, 1906; ibid., October 22, November 2, 4, 16, 1907.

32. Alberto Leal, Douglas consul, to Mariscal, September 27, 1907, AHSRE, 18-2435; García to Mariscal, October 18, 1908, and April 5, 1910, ibid., 12-5-79; Escobar, "Indicaciones relativas a la colonización," p. 316.

33. Díaz report of April 1, 1908, to the Mexican Congress in Coahuila, Periódico Oficial 16 (April 4, 1908): 1; Martínez, Border Boom Town, pp. 34-6.

34. Unsigned memorandum of July 6, 1910, in AHSRE, 30-50-35; Ambassador Francisco León de la Barra to Enrique Creel, Secretary of Foreign Relations, June 19, 1910, ibid., 17-10-358.

35. Manuel Calero, Subsecretary of Development, to Creel, June 29, 1910, ibid., 18-25-32; El Imparcial, April 10, 1909; ibid., February 26, March 4, June 19, and August 20, 1910.

36. Ricardo Bravo, Phoenix consul, to Mariscal, November 9, 1909, AHSRE, 3073-7; García to Mariscal, October 18, 1908, ibid., 12-5-79; Federico Gamboa, Subsecretary of Foreign Relations, to De la Barra, July 20, 1910, ibid., 12-6-14.

37. Report of the United States Immigration Commission, vol. 1, pp. 41, 689, 691 (quote).

38. Congressional Record 36 (December 8, 1902): 104 (quotes); Prescott F. Hall, Immigration and Its Effects Upon the United States, 2nd ed. (New York: Henry Holt and Company, 1913), pp. 270-271, n. 22.

39. Congressional Record 36 (December 8, 1902): 100; Report of the Secretary of Commerce and Labor and Reports of Bureaus, 1905 (Washington: GPO, 1906), pp. 606, 630-632; Report ... Commerce and Labor . . 1907, pp. 146, 184-86; Report ... Commerce and Labor ... 1908, pp. 231-38. 
40. Report ... Commerce and Labor ... 1910, p. 314; Clark, "Mexican Labor in the United States,"'pp. 466, 521.

41. Report ... Commerce and Labor ... 1910, p. 230; Report of the United States Immigration Commission, vol. 25, pt. 3, p. 26; Moisés González Navarro, "Los braceros en el Porfiriato," Estudios Sociológicos del Quinto Congreso Nacional de Sociología, vol. 5, tomo segundo (1954), p. 263.

42. Report ... Commerce and Labor ... 1910, pp. 107, 129-32; Bureau of the Census, Twelfth Census of the United States: 1900, Supplementary Analysis and Derivative Tables (Washington: GPO, 1906), p. 177.

43. Thirteenth Census of the United States Taken in the Year 1910, vol. I: Population, pp. 875, 879; Fifteenth Census of the United States: 1930, Population: Volume 2, p. 27.

\section{CHAPTER 3}

1. José Puig Casauranc, De nuestro México (Mexico: n.p., 1926), p. 97; Charles C. Cumberland, Mexican Revolution: The Constitutionalist Years (Austin: University of Texas Press, 1972), pp. 39, 123, 139, 400, passim; Luis González y González, San José de Gracia: Mexican Village in Transition, Trans. John Upton, 2nd ed. (Austin: University of Texas Press, 1974), pp. 129-38; William B. Davis, Experiences and Observations of an American Consular Officer During the Recent Mexican Revolutions (Los Angeles: Author, 1920), pp. 145-51.

2. Angel Caso, Derecho agrario (Mexico: Porrua, 1950), pp. 486-98; Manuel González Ramírez (ed.), Fuentes para la historia de la Revolución mexicana, 4 vols. (Mexico: Fondo de Cultura Económica, 1954-1957) vol. 4, passim, has decrees of other revolutionary chieftains; Salvador Lira López et al., La pobreza rural en México (Mexico: Banco de Crédito Ejidal, 1945), p. 21; Tannenbaum, The Mexican Agrarian Revolution, pp. 399-401.

3. Ricardo Bravo, Del Rio consul, to Headquarters, September 23, 1912, AHSRE, 16-8-90; Commissioner General of Immigration, Annual Report, 1914 (Washington: GPO, 1915), p. 340.

4. Gamio, The Mexican Immigrant, pp. 2-3, 6, 58 (quote).

5. Ibid., p. 217; Puig Casauranc, De nuestro México, p. 97; Commissioner General of Immigration, Annual Report, 1914, p. 340; Arizona Gazette, May 2, 1911, in AHSRE, “Ramo de la Revolución mexicana,"'III/513 “911,"' R-43-17, 73-37.

6. Memorandum of November 17, 1917, [name illegible] to Carranza, Carranza papers; Cumberland, Constitutionalist Years, pp. 397-98; Michael C. Meyer, Huerta: A Political Portrait (Lincoln: University of Nebraska Press, 1972), pp. 180-81; Martínez, Border Boom Town, p. 41; Davis, Experiences and Observations, p. 36.

7. Merle E. Simmons, The Mexican Corrido as a Source for Interpretive Study of Modern Mexico (Bloomington: Indiana University Press, 1957), pp. 142-43.

8. "Cost of Living in Mexico, 1910, and February to May, 1921," Monthly Labor Review 13 (September, 1921): 71-72; Carranza papers, passim; El Universal, November 13 and 17, 1916; ibid., November 20, 1918; Fernando González Roa, El aspecto agrario de la Revolución mexicana (Mexico: Talleres Gráficos de la Nación, 1919), 170; Edwin Kemmerer, Inflation and Revolution: Mexico's Experience of 1912-1917 (Princeton: Princeton University Press, 1940), pp. 46-61; Bernstein, Mexican Mining Industry, pp. 99-105, 118-23. 
9. Gamio, The Mexican Immigrant, pp. 87-89.

10. Quoted in Simmons, The Mexican Corrido, p. 142.

11. Ibid., p. 169 (quote).

12. Edwin Lieuwin, Mexican Militarism (Albuquerque: University of New Mexico Press, 1968), p. 37 (first quote); Ernesto Galarza, Barrio Boy (Notre Dame: University of Notre Dame Press, 1971), p. 168 (second quote); Simmons, The Mexican Corrido, p. 168; Carranza papers, passim.

13. Harry A. Franck, Tramping Through Mexico, Guatemala and Honduras (New York: The Century Co., 1916), p. 159; Emile J. Dillon, Mexico on the Verge (New York: George H. Doran Co., 1921), p. 27.

14. Commissioner General of Immigration, Annual Report, 1912, pp. 224-25 (first quote); idem, Annual Report, 1916 (second quote); idem, Annual Report, 1917, p. 83; Report ... Commerce and Labor ... 1911, p. 314.

15. San Diego Union, May 8, 1911, in AHSRE, "Ramo de la Revolución mexicana," III/513 “911”'/R-43-20; El Paso Herald, December 16, 1910, ibid., III/H/513 “910”-20-1. L-E-620; New York Times, January 12 and 13, 1914; ibid., January 5, 1915; Robert McLean and Grace Petrie Williams, Old Spain in New America (New York: Council of Women for Home Missions, 1916), pp. 62-63, 155-58, 131-38; Ricardo Romo, "Mexican Workers in the City: Los Angeles, 1915-1930," (Ph.D. dissertation in History, University of California, Los Angeles, 1975), pp. 189-92.

16. Nash, The American West in the Twentieth Century, pp. 66-67, 76-77, 96-98; Jesús González, Nuestros problemas (Mexico: México Moderno, 1921), p. 28; Rosalio Moisés, The Tall Candle (Lincoln: University of Nebraska Press, 1971), p. 75; Yves Lelevier, Globe consul, to Cándido Aguilar, Secretary of Foreign Relations, August 17, 1917, AHSRE, 13-14-40; El Universal, March 3, 1920; U.S. Senate, Investigation of Mexican Affairs (2 vols.; Washington: GPO, 1920), vol. 2, p. 2162.

17. Frank L. Polk, Acting Secretary of State, to Marion Letcher, Foreign Trade Advisor of the Department of State, January 2, 1918, RG 59, 811.504/85; Truman G. Palmer to Robert Lansing, Secretary of State, August 8, 1917, ibid., 811.504/ 42; U.S. Congress, House Committee on Immigration and Naturalization, Temporary Admission of Illiterate Mexican Laborers (Washington: GPO, 1920), pp. 19, 30, 37, 169-70; Commissioner General of Immigration, Annual Report, 1918, p. 317.

18. Roy Garis, Immigration Restriction: A Study of the Opposition to and Regulation of Immigration into the United States (New York: Macmillan, 1927), pp. 125 (quote), 118.

19. Ibid., pp. 159, 164.

20. Commissioner General of Immigration, Annual Report, 1918, p. 319.

21. William Wilson, Secretary of Labor, to Anthony Caminetti, Commissioner General of Immigration, May 23, 1917, RG 59, 811.504/28; Avery Turner to John Silliman, Guadalajara consul, November 12, 1918, ibid., 811.504/139.

22. Ibid.; C. M. Rork to Lansing, June 17, 1917, ibid., 811.504/104; Polk to Embassy, Mexico City, July 26, 1918, ibid., 811.504/120a.

23. Report of the Secretary of Labor, 1918, pp. 692-93.

24. Otey Scruggs, "The First Farm Labor Program, 1917-1921," Arizona and the West 2 (Winter 1960): 321. 
25. Ibid., pp. 323-24; Excelsior, December 10, 1917; ibid., December 25, 1918.

26. Galarza, Barrio Boy, pp. 200-02; Rodolfo Acuña, Occupied America (New York: Canfield Press, 1972), pp. 6-122, details Anglo-Mexican border tensions and hatreds. Robert McLean, That Mexican! (New York: Revell \& Co., 1928), and Alden Case, Thirty Years with the Mexicans (New York: Revell \& Co., 1917), are accounts by two Protestant missionaries.

27. Public Law 12 (May 18, 1917), Selective Service Act, Statutes at Large, 60, pp. 78, 80; Gamio, The Mexican Immigrant, p. 56; El Paso del Norte (El Paso, Texas), May 23, 1917.

28. Lelevier to Aguilar, August 24, 1917, AHSRE, 13-14-3; Douglas Daily Dispatch, August 25, 1917, ibid.; Consul General Teódulo Beltrán to Carranza, July 27, 1917, Carranza papers.

29. El Paso del Norte, June-July, 1917, passim; George Chamberlain, Consul General, to Lansing, May 19, 1917, RG 59, 811.504/23.

30. Eagle Pass, Texas Chamber of Commerce to Lansing, May 26, 1917, RG 59, 811.504/86; El Paso del Norte, August 23, 1917.

31. Posters in RG 59, 811.504/86; William Hanna, Consul General, to Lansing, May 24, 1917, ibid., 811.504/24; Hanna to Lansing, June 4, 1917, ibid., 811.504/29.

32. Wilbur Carr, Director of the Consul Service, to Lansing, June 6, 1917, ibid., 811.504/23; Hanna to Lansing, August 21, 1917, ibid., 811.504/49; El Universal, July $15,1918$.

33. Caminetti to Boaz Long, Chief of the Division of Mexican Affairs of the Department of State, January 4, 1919, RG 59, 811.504/145; Report of the Secretary of Labor, 1919, pp. 707-09; House Committee on Immigration and Naturalization, Temporary Admission of Illiterate Mexican Laborers, passim, for arguments for the continuation of wartime waivers.

34. House Committee, Temporary Admission of ... Laborers, passim, for the uses of bracero labor; Taylor, Mexican Labor ... Imperial Valley, p. 8; Report of the Secretary of Labor, 1920, p. 693.

35. Report of the Secretary of Commerce and Reports of Bureaus, 1920, pp. 197-98, 200, 208, 223; Bureau of the Census, Fourteenth Census of the United States Taken in the Year 1920, Vol. 2: Population (Washington: GPO, 1922), pp. 891, 897; New York Times, June 20, 1920; McLean and Williams, Old Spain in New America, p. 54; Bureau of the Census, Fifteenth Census of the United States: 1930, Population: Vol. 2, p. 27.

\section{CHAPTER 4}

1. Womack, Zapata and the Mexican Revolution, passim; Rafael Hernández, Política agraria, julio de 1911 a junio de 1912 (Mexico: Imprenta de la Secretaría de Fomento, 1912), in Silva Herzog (ed.), La cuestión de la tierra, vol. 2, p. 117; Escobar, "Indicaciones relativas a la colonización," ibid., vol. 1, pp. 315-16; Toribio Esquivel Obregón, El problema agrario de México (Mexico: Imprenta de la Vda. de Ch. Bouret, 1912), ibid., vol. 2, p. 132; Michael C. Meyer, Huerta, pp. 164-65.

2. Hernández, Política agraria, julio de 1911 a junio de 1912, p. 117; Moisés Gon- 
zález Navarro, Población y sociedad en México, 1900-1970, 2 vols. (Mexico: UNAM, 1974), vol. 2, p. 151.

3. González Navarro, Población y sociedad en México, vol. 2, pp. 224-25; Enrique Llorente, El Paso consul, to Madero, January 20, 1912, Ramo Madero, Archivo General de la Nación, Mexico City, file 667-2.

4. Manuel Bonilla, Apuntes para el estudio del programa agrario (Hermosillo: Imprenta del Estado, 1914), p. 26; El Universal, August 13, 1920.

5. Diario Oficial 8 (November 7, 1917): 395.

6. González Navarro, Población y sociedad en México, vol. 1, p. 120 (first quote); Narciso Bassols Batalla, El pensamiento político de Alvaro Obregón, 2nd ed. (Mexico: El Caballito, 1970), p. 74 (second quote); González Navarro, Población y sociedad, vol. 2, p. 179 (third quote); El Universal, December 12, 1916; Gustavo Durán, "Importancia de la agricultura y del fraccionamiento de tierras," paper read to the Antonio Alzate Scientific Society, September, 1911, in Silva Herzog (ed.), La cuestión de la tierra, vol. 1, pp. 190-91; Francisco Loria, Algunas consideraciones acerca del problema agrario (Mexico: Tip. de la Escuela Industrial de Húerfanos, 1916); idem, Lo que causa el atraso y la miseria de nuestro pueblo y la manera de aliviarlo (Mexico: Secretaría de Fomento, 1915).

7. Diario de los debates del Congreso Constituyente, 1916-1917, 2 vols. (Mexico: Secretaría de Gobernación, 1960), vol. 2, pp. 833, 860, 863.

8. Diario Oficial 7 (November 11, 1917): 395; ibid. 14 (March 17, 1920): 1225-26; ibid. (March 23, 1920): 1345-47.

9. Aguilar to Manuel Aguirre Berlanga, Secretary of Interior, June 14, 1918, AHSRE, 16-24-25; El Universal, March 17, 1920 (quote); New York Times, July $20,1918$.

10. A large body of scholarship deals with diplomatic relations during the first decade of the Revolution. See, for example, Robert Quirk, An Affair of Honor: Woodrow Wilson and the Occupation of Veracruz (Lexington: University of Kentucky Press, 1962); Berta Ulloa, La Revolución intervenida: relaciones diplomáticas entre México y Estados Unidos (1910-1914) (Mexico: Colegio de México, 1971); Robert F. Smith, The United States and Revolutionary Nationalism in Mexico, 1916-1932 (Chicago: University of Chicago Press, 1972); Lorenzo Meyer, Mexico and the United States in the Oil Controversy, 1917-1942, Trans. Muriel Vasconcellos, 2nd ed. (Austin: University of Texas Press, 1977).

11. Memoria de la Secretaria de Gobernación correspondiente al periodo revolucionario comprendido entre el 19 de febrero de 1913 y el 30 de noviembre de 1916, 2 vols. (Mexico: n.p., 1933), vol. 2, p. 509; Manuel González Ramírez, La Revolución social de México, 3 vols. (Mexico: UNAM, 1960), vol. 2, p. 387 (quote); McBride, The Land Systems of Mexico, p. 33; Fletcher to Lansing, March 6,1918 , in U.S. Department of State, Papers Relating to the Foreign Relations of the United States, 1918 (Washington: GPO, 1930), pp. 606, 635-36.

12. Diario Oficial 14 (March 10, 1920): 1089-90 (quote); ibid. (March 9, 1920): 1057-58; Adolfo de la Huerta, Sonora governor, to Carranza, September 10, 1916, Carranza papers; Alfonso Fábila, El problema de la emigración de obreros y campesinos mexicanos (Mexico: Talleres Gráficos de la Nación, 1929); El Universal, 1916-20, passim, for newspaper propaganda.

13. Aguilar to Jesús Acuña, Secretary of Interior, June 17, 1916, AHSRE, 17-20-21; Diario Oficial 8 (April 18, 1918): 1139; El Universal, April 15, 1918. 
14. Diario Oficial 14 (March 24, 1920): 1372; Alberto Ruiz Sandoval, El Paso Consul, to Aguilar, undated, AHSRE, 11-19-24. Typical examples of Yankeephobia include Querido Moheno, Cosas del Tio Sam (Mexico: Revista Mexicana, 1916), pp. 55-57; Fábila, El problema de la emigración, passim.

15. Ferris to Lansing, March 11, 1920, RG 59, 811.504/203; Diario Oficial 8 (January 23, 1918): 196; Juan Gómez-Quiñones, "The First Steps: Chicano Labor Conflict and Organizing, 1900-1920,' Aztlán, 3 (Spring, 1972), 13-49.

16. Thomas Brennan, Monterrey consul, to Lansing, March 20, 1920, RG 59, 811.504/201; Silliman to Turner, November 23, 1918, ibid., 811.504/213.

17. Undated clipping from Baja California Periódico Oficial, RG 59, 811.504/213; Lansing to Henry Ashurst, October 6, 1917, ibid., 811.504/56.

18. Diario Oficial 14 (March 17, 1920): 1225-26, gives a resume of circulars sent to Department of Migration officials.

19. Diario Oficial 14 (March 17, 1920), 1225-26; ibid. (March 24, 1920): 1373.

20. El Universal, March 17 and June 18, 1920.

21. Ibid., September 21, 1917 (quote); circular \# 13, November 10, 1916, AHSRE, 22-14-1.

22. Circular \# 14, November 11, 1916, AHSRE, 22-14-1.

23. Diario Oficial 8 (January 23, 1918): p. 196; Lelevier to Aguilar, August 27, 1917, AHSRE, 13-14-30.

24. Gamio, The Mexican Immigrant, pp. 56, 137, 216 (quote).

25. Unsigned memorandum of June 10, 1922, entitled "Mexicanos emigrantes, medidas sugeridas para controlar sus energías," Obregón papers, 711-M-30; Enrique Colunga, Chief of the Legal Office of the Department of Migration, to Obregón, March 18, 1921, ibid., 822-M-1; U.S. Department of State, annual Registers for the names and jurisdictions of Mexican consuls.

26. Diario Oficial 14 (March 17, 1920): 1225; Aguirre Berlanga to Ramón P. Denegri, Consul General, June 14, 1918, AHSRE, 16-24-25.

27. Lelevier to Aguilar, August 27, 1917, AHSRE, 13-14-30.

28. Bonillas to Polk, January 22, 1919, Department of State Decimal File, National Archives, Washington, D.C., RG 59, 311.12/380; New York Times, September 16, 1919.

29. Beltrán to Aguilar, May 25, 1918, AHSRE, 13-14-22.

30. Manuel Rico, Tucson consul, to Andrés Garcia, Inspector General of Consulates, October 8, 1917, ibid., 13-13-55; Aguilar to Raúl Dominiguez, San Diego consul, October 22, 1917, ibid.; Adelaido Ortiz, Denver consul, to Aguilar, ibid.

31. Bonillas to all consuls, September 22, 1917, ibid., 13-14-3; García to Aguilar, August 21, 1917, ibid.; Mexico, Foreign Office, Diplomatic Dealings of the Constitutionalist Revolution of Mexico (Mexico: Secretary of Foreign Relations, 1919), p. 417.

32. Rafael Calvo y Arias, Baltimore consul, to Aguilar, September 3, 1918, AHSRE, 1451; Ornelas-Bonillas correspondence, dated September 11 to 20, 1917, ibid., 13-14-3; Hernández to Garcia, August 28, 1917, ibid., 62-R-2; Lelevier to Aguilar, July 20,1917 , ibid. 


\section{CHAPTER 5}

1. Alexander Weddell, Consul General, to Headquarters, March 23, 1927, RG 59, 150.126/165; González y González, San José de Gracia, pp. 142, 158 (quote); Gamio, The Mexican Immigrant, p. 43; Jean A. Meyer, The Cristero Rebellion: The Mexican People Between the Church and State, 1926-1929 (New York: Cambridge University Press, 1976), pp. 178-79; John W. F. Dulles, Yesterday in Mexico (Austin: University of Texas Press, 1961), passim, for a factual account of the various outbursts of violence during this period.

2. Sindicato de Obreros y Campesinos de Michoacán to Obregón, March 7, 1923, Obregón papers, 818-S-235; Francisco and Antonio Garfías to Calles, June 11, 1925, Calles papers, 818-A-170; Silva Herzog, El agrarismo mexicano y la reforma agraria, pp. 287, 364 .

3. Governor of Guanajuato to Calles, January 28, 1926, Calles papers, 818-C-148; Macario Franco to Emilio Portes Gil, December 20, 1929, Portes Gil papers, 6/837/707.

4. A. R. Gómez to Obregón, November 8, 1922, Obregón papers, 101-P-12; Lieuwin, Mexican Militarism, pp. 59-61, 95, 99; Heather Fowler Salamini, Agrarian Radicalism in Veracruz, 1920-38 (Lincoln: University of Nebraska Press, 1978), p. 39.

5. Ricardo Treviño, La acción mexicana frente de la actual situación (Mexico: Talleres La Lucha, 1927), pp. 19-20; El Universal, February 23, 1930; Cumberland, Mexico, p. 367; Secretaría de la Presidencia y Nacional Financiera, 50 años en cifras, p. 52.

6. Melesio Díaz to Obregón, April 6, 1923, Obregón papers, 818-S-228; Silva Herzog, El agrarismo mexicano y la reforma agraria, pp. 322, 340; Lorenzo Meyer, El conflicto social y los gobiernos del Maximato (Mexico: Colegio de México, 1978), pp. 34-5, 173-210.

7. México, Secretaría de Industria, La industria, el comercio y el trabajo en México, 5 vols. (Mexico: Tip. Galas, 1928), vol. 3, pp. 64-65; Ernest Gruening, Mexico and Its Heritage (New York: Appleton-Century-Crofts, 1928), pp. 136-37.

8. México, Secretaría de Industria, Monografía sobre el estado actual de la industria en México (Mexico: Talleres Gráficos de la Nación, 1929), pp. 63-66; Reynolds, The Mexican Economy, pp. 44, 102-05, 163; Jean Meyer, Estado y sociedad con Calles (Mexico: Colegio de México, 1977), pp. 151-74.

9. Simmons, The Mexican Corrido, pp. 193-94 (first quote), 178 (second quote).

10. Ibid., p. 179.

11. González to Obregón, March 7, 1921, Obregón papers, 817-S-37; Escalante to Calles, July 20, 1927, Calles papers, 818-C-199; Taylor, Mexican Labor ... Chicago, p. 260 (quote).

12. Quoted in Simmons, The Mexican Corrido, p. 348.

13. Quoted in Paul S. Taylor, "Songs of the Mexican Migration," in J. Frank Dobie (ed.), Puro Mexicano (Austin: Texas Folk-Lore Society, 1935), pp. 238-39.

14. Ibid., pp. 222-24, (quote).

15. Palacios to Portes Gil, August 9, 1929, Portes Gil papers, 5/619/805; Lima to 
Calles, November 25, 1925, Calles papers, 724-L-1; C. González to Calles, July 20, 1927, ibid., 822-G-14; Taylor, Arandas, p. 39.

16. G. R. Carreón to Calles, January 1, 1928, Calles papers, Serie A; Taylor, Mexican Labor ... Chicago, p. 263.

17. Taylor, Mexican Labor ... Chicago, pp. 271-72 (first and second quotes); Gamio, The Mexican Immigrant, pp. 133-34 (third quote).

18. Quoted in Manuel Gamio, Mexican Immigration to the United States (Chicago: University of Chicago Press, 1930), pp. 93-94.

19. Quoted in Vicente Mendoza, Lírica narrative de México: el corrido (Mexico: UNAM, 1964), pp. 396-97.

20. Macedonio Navarro et al., to Calles, January 5, 1928, Calles papers, 213-CH-I; Francisco Santiago to Obregón, July 9, 1921, Obregón papers, 213-S-1.

21. Quoted in Gamio, Mexican Immigration, p. 107; I have corrected the verb tense in line five.

22. Ibid., pp. 52-55; Gamio, The Mexican Immigrant, pp. 176 (quote), 177, 179, 185-86; ibid., pp. 46, 48-49, 109, 119; interview with Gilberto Loyo, July 19, 1971, Mexico City.

23. Quoted in Taylor, "Songs of the Mexican Migration," pp. 241-43.

24. Except as noted, these and other statistics are from the Annual Reports, 1920 to 1929.

25. Gamio, Mexican Immigration, pp. 30-32; Postmaster General of the United States, Annual Reports, 1920 to 1929.

26. Garis, Immigration Restriction, p. 146.

27. Ibid., p. 170 (first quote); Jones, American Immigration, p. 277 (second and third quotes).

28. Gamio, Mexican Immigration, p. 204.

29. Commissioner General of Immigration, Annual Report, 1928, p. 69; idem, Annual Report, 1926, pp. 52-53; Mary Rak, Border Patrol (Boston: Houghton Mifflin, 1938), passim.

30. Gamio, Mexican Immigration, pp. 205-07.

31. Ibid., pp. 11-12.

32. Francis I. Jones, Director General of the United States Employment Service, to Warren G. Harding, June 23, 1923, Harding papers, roll 140, file 15; Bureau of the Census, United States Census of Agriculture, 1925. Part III: The Western States (Washington: GPO, 1927), pp. 38, 46-47; Carter Goodrich et al., Migration and Planes of Living, 1920-1934 (Philadelphia: University of Pennsylvania Press, 1935), pp. 59-60.

33. U.S. Congress, Senate, Committee on Immigration, Restriction of Western Hemisphere Immigration, 70th Congress, 1st Session, 1928, pp. 89-91, 111 (quote).

34. Taylor, Mexican Labor ... Chicago, pp. 71-72; Anita Jones, Conditions Surrounding Mexicans in Chicago (San Francisco: R \& E Research Associates, 1971), p. 66. 
35. Taylor, Mexican Labor ... South Platte, pp. 114-16; U.S. Congress, House, Committee on Immigration and Naturalization, Seasonal Agricultural Laborers from Mexico, 69th Congress, 1st Session, 1929, pp. 29-30, 120-23; Mark Reisler, By the Sweat of Their Brow: Mexican Immigrant Labor in the United States, 1900-1940 (Westport: Greenwood Press, 1976), pp. 77-126, for a good account of employment patterns in the 1920s.

36. Richard Boyce, Nuevo Laredo consul, to Kellogg, September 19, 1928, RG 59, 811.111 Mexico/100; Paul S. Taylor, Mexican Labor in the United States: Dimmit County, Winter Garden District, South Texas, University of California Publications in Economics, VI, number 5, (Berkeley, 1930), p. 325; idem, Mexican Labor ... Imperial Valley, pp. 16-17.

37. Schwartz, Seasonal Farm Labor, pp. 113-14; Jane Addams, The Second Twenty Years at Hull House (New York: MacMillan, 1930), p. 282; Paul S. Taylor, Mexican Labor in the United States: Bethlehem, Pennsylvania, University of California Publications in Economics, VI, number 2 (Berkeley, 1930), passim.

38. Seasonal Agricultural Laborers, pp. 13-15; Stowell, The Near Side, pp. 40-41.

39. Paul S. Taylor, "Unpublished Field Notes on Mexican Labor in the United States," Paul S. Taylor papers, Bancroft Library, University of California, Berkeley, passim; Charles Hufford, The Social and Economic Effects of Mexican Migration into Texas (San Francisco: R \& E Research Associates, 1971).

40. Gamio, Mexican Immigration, pp. 37 (quote), 38-41, 45-46.

41. Ibid., pp. 38, 41; see also L. G. Villalpando, Kansas City consul, to Secretary of Industry, May 9, 1922, in Boletín del Archivo General de la Nación, 3rd series, 2 (enero-marzo, 1978), pp. 15-7.

42. McLean, That Mexican!, pp. 125 (quote), 135, 141; Taylor, Mexican Labor... South Platte, pp. 170-71; J. B. Gwin, "Social Problems of Our Mexican Population," Proceedings (National Conference of Social Work), 1926 (Chicago: University of Chicago Press, 1926), p. 332; Fact-Finding Committee, Mexicans in California, p. 191.

43. A. F. Beddoe to Calles, February 18, 1928, Calles papers, 121-R-E-I.

44. Fact-Finding Committee, Mexicans in California, p. 192; John O'Grady, Catholic Charities in the United States (Washington: National Conference of Catholic Charities, 1930), pp. 301-02.

45. Gamio, The Mexican Immigrant, pp. 198 (quote), 198-200.

46. Bureau of the Census, Fifteenth Census of the United States: 1930, Population: Vol. II (Washington: GPO, 1933), passim; Commissioner General of Immigration, Annual Reports, 1925 to 1929; Taylor, Mexican Labor ... Chicago, p. 2.

47. Gamio, Mexican Immigration, p. 156 (quote); Taylor, Mexican Labor ... Chicago, pp. 166-71; Taylor, Mexican Labor ... Dimmitt County, p. 370; idem, Mexican Labor . . . Imperial Valley, p. 72.

48. Constantine Panunzio, How Mexicans Earn and Live, A Study of the Incomes and Expenditures of One Hundred Mexican Families in San Diego, California (Berkeley: University of California Press, 1933), pp. 48-49, 52, 55, 67, passim.

49. Fact-Finding Committee, Mexicans in California, p. 77; Bureau of the Census, Special Report on Foreign-Born White Families by Country of Birth of Head (Washington: GPO, 1933), pp. 201, 211-12. 
50. O. Douglas Weeks, "The League of United Latin-American Citizens: A TexasMexican Civic Organization," Southwestern Political and Social Science Quarterly 10 (December 1928): 257-68; Matt. S. Meier and Feliciano Rivera, The Chicanos: A History of Mexican Americans (New York: Hill and Wang, 1972), pp. 240-41.

51. Andres Landa y Piña, El Servicio de Migración en México (Mexico: Talleres Gráficos de la Nación, 1930), pp. 19, 23; Gamio, Mexican Immigration, pp. $7-12$.

52. Commissioner General of Immigration, Annual Report, 1920, p. 709; Davis to Cole, April 15, 1924, Congressional Record (April 1925): 1366-67; Estrada to Portes Gil, June 5, 1929, AHSRE, 33-42-19.

53. Bureau of the Census, Fifteenth Census of the United States: 1930, Population: Vol. II, pp. 2, 25-27; Arthur F. Corwin, "¿Quien Sabe? Mexican Migration Statistics," in Arthur F. Corwin (ed.), Immigrants - and Immigrants: Perspectives on Mexican Labor Migration to the United States (Westport: Greenwood Press, 1978), pp. 109, 115, 130.

\section{CHAPTER 6}

1. 'President's Conference on Unemployment,"' Monthly Labor Review 13 (November 1921): 128; John D. Hicks, Rehearsal for Disaster: The Boom and Collapse of 1919-1920 (Gainesville: University of Florida Press, 1961), pp. 77-78.

2. El Universal, February 21 and 23, August 5, 1921; Los Angeles Times, February $17,1921$.

3. Los Angeles Times, March 10, 1921; Secretary of Labor, Annual Report, 1921, p. 16; Commissioner, Montreal, Canada, to Anthony Caminetti, Commissioner General of Immigration, December 23, 1920, RG 85, 11212/28; Inspector in charge to Commissioner, Montreal, Canada, February 22, 1921, ibid., 2106/G.

4. Pereda to Thompson, April 25, 1921, RG 85, 55091/6; W. Frank Persons, American Red Cross, to Walter W. Husband, Commissioner General of Immigration, May 9, 1921, ibid.; Hampton to Department of State, February 14, 1921, ibid., 54261/202-P; El Universal, December 23, 1920.

5. Robert Bondy, Director of the Southwestern Division of the American Red Cross, to Husband, April 15, 1921, RG 85, 55091/6; Hampton to Charles Johnston, Division of Mexican Affairs of the Department of State, March 28, 1921, ibid.; Hampton to Representative Joseph Fordney, March 19, 1921, ibid., 54261/202-P.

6. Cockrell to Obregón, May 18, 1921, Obregón papers, 822-M-1.

7. Dulles, Yesterday in Mexico, pp. 106-07; El Universal, December 10, 1921.

8. Aarón Sáenz, Subsecretary of Foreign Relations, to Adolfo de la Huerta, Secretary of Treasury, May 11, 1921, Obregón papers, 822-M-1; Obregón to Alberto J. Pani, Secretary of Foreign Relations, February 6, 1921, ibid., 121-R-M; a copy of the memorandum is in Obregón papers, 822-M-1; unsigned memorandum of January 1923, in AHSRE, 36-16-318.

9. Documentation for events in Ray is a series of telegrams exchanged between Obregón and Pecina from April 2 to May 2, 1921, in Obregón papers, 121-R-M and 814-R-5. 
10. Obregón to Ruiz, January 29, 1921, ibid., 407-A-2; Scruggs, “First Farm Labor Program," p. 325.

11. Ruiz to Obregón, February 9, 1921, Obregón papers, 429-P-2; Obregón to Priego, April 23, 1921, ibid., 822-M-1.

12. Series of telegrams between Obregón and Gaxiola dated May 3 to June 9, 1921, ibid.

13. Ruiz to Obregón, December 31, 1921, ibid.; Norman Humphrey, "Mexican Repatriation from Michigan: Public Assistance in Historical Perspective,' Social Service Review 15 (September 1941): 500.

14. Inspector in charge to Commissioner, Montreal, Canada, February 22, 1921, RG 85, 2106/G; Ruiz to Obregón, May 4, 1921, Obregón papers, 822-M-1; Obregón to President, Southern Pacific Company, May 4, 1921, ibid.; F. S. McGinnis, General Passenger Agent, Southern Pacific Company, to Los Angeles County Charities, May 6, 1921, ibid. (copy only).

15. Sáenz to Obregón, January 24, 1921, ibid.; Pecina to Obregón, May 2, 1921, Obregón papers, 822-M-1; William Kemper, President Kansas City, Mexico and Orient Railway, to Obregón, June 2, 1921, ibid.; Francisco Alatorre, national Railroad Administration, to Obregón, June 2, 1921, ibid.; El Universal, September 2, 1921.

16. Obregón to Denver, Colorado Mexican colony, February 15, 1922, Obregón papers, 822-C-424; Obregón to Governor of Chihuahua, February 15, 1921, ibid.; El Universal, March 12, 1922; Mercedes Carreras de Velasco, Los mexicanos que devolvió la crises 1929-1932 (Mexico: Secretaría de Relaciones Exteriores, 1974), pp. 48-49.

17. Gamio, Mexican Immigration, pp. 57, 71, 128, 177-78.

18. Ibid., pp. 74-75, 114-17.

19. El Universal, March 29 and July 6, 1927 (first and second quotes); Excelsior, March 20, 1924 (third and fourth quotes); Gustavo Durón González, Problemas migratorios de México (Mexico: Talleres de la Cámara de Diputados, 1925), pp 71, 117. Gilberto Loyo (ed.), El inmigrante mexicano (Mexico: UNAM, 1969).

20. Rafael Muñoz, "El Repatriado," in his Si me han de matar mañana (Mexico: Ediciones Botas, 1934), pp. 177-92; F. Rand Morton, Los novelistas de la Revolución mexicana (Mexico: Editorial Cultura, 1949), pp. 142-43. For similar baleful fiction see Ignacio Muñoz, La verdad sobre los gringos (Mexico: Ediciones Populares, 1927).

21. El Universal, March 12, 1923 (first quote), July 6, 1927; Excelsior, September 12 , 1927 (second quote), February 22 and May 25, 1929.

22. Gilberto Loyo, Emigración de mexicanos a los Estados Unidos (Rome: Instituto Poligráfico dello Stato, 1931), passim; Gilberto Loyo, La política demográfica de México (Mexico: Talleres Tipográficos de S. Turanzas del Valle, 1935), pp. 375-76; Santibáñez, Ensayo, pp. 48-49; González Navarro, Población y sociedad, vol. 2, pp. 181-82.

23. Obregón to Pani, May 19, 1921, Obregón papers, 814-R-5.

24. Pani to Calles, April 5, 1922, AHSRE, 36-16-318; Enrique González, Consul General, to Genaro Estrada, Secretary of Foreign Relations, January 20, 1930, ibid., 18-22-7; Kaye Lynn Briegel, “Alianza Hispano-Americana, 1894-1965: A 
Mexican American Fraternal Insurance Society," (Ph.D. dissertation in History, University of Southern California, 1974), pp. 1-107.

25. Headquarters to all consuls, September 3, 1926, AHSRE, 73-1-1, circular number 5630; Colunga to Obregón, March 18, 1921, Obregón papers, 822-M-1.

26. Gamio, Mexican Immigration, p. viii; Calles to Arturo Butchart, Gran Liga de Resistencia de Nacionales Sin Trabajo, July 15, 1925, Calles papers, 711-L-21; Santibánez to all consuls, February 15, 1929, AHSRE, 015-73-46/1.

27. Congreso de los Estados Unidos Mexicanos, Cámara de Diputados, Proyecto de Ley de Migración enviado por el Poder Ejecutivo (Mexico: Imprenta de la Cámara de Diputados, 1923); Secretaría de Gobernación, Ley de Migración de los Estados Unidos Mexicanos. Edición Oficial (Mexico: Talleres Gráficos de la Nación, 1926); González Navarro, Población y sociedad, vol. 2, pp. 38-39; Bassols Batalla, El pensamiento político de Alvaro Obregón, pp. 74-75.

28. "Ley de Migración de los Estados Unidos de México," Diario Oficial 61 (August 30, 1930): supplement, pp. 1-12; Estrada to Ambassador José Puig Casauranc, January 27, 1931, AHSRE, 016/1/238-7.

29. Unsigned memorandum of June 10, 1922, in Obregón papers, 711-M-30 (quote and substance); Smith, The United States and Revolutionary Nationalism, pp. 200-202; Karl M. Schmitt, Mexico and the United States, 1821-1973 (New York: John Wiley \& Sons, Inc., 1974), p. 162.

30. Schmitt, Mexico and the United States, p. 162; Estrada to Santibáñez, February 27, 1929, AHSRE, 015-73-46/1; Lorenzo Meyer, Mexico and the United States in the Oil Controversy, 1917-1942, trans. Muriel Vasconcellos (Austin: University of Texas Press, 1977), pp. 81-104.

31. Silva Herzog, El agrarismo mexicano y la reforma agraria, pp. 285 (quote), 287.

32. Meyer, The Cristero Rebellion, pp. 24-29; San Antonio, Texas, La Prensa clipping dated October 1929, in Portes Gil papers, 4/724/217; González Navarro, Población y sociedad, vol. 2, p. 163.

33. Fábila, El problema de la emigración, pp. 8-11, 13, 26, 30, 32-34, passim.

34. Obregón to Calles, March 7, 1923, Obregón papers, 822-C-5; Calles to Canales, January 26, 1928, Calles papers, 822-L-5; Kellogg to Davis, June 26, 1926, RG $59,150.128 / 70$.

35. Harper to Kellogg, September 17, 1925, RG 59, 812.5611/1; David Meyers, Durango consul, to headquarters, March 7, 1924, ibid., 150.126/141.

36. Dwyre to Kellogg, May 12, 1930, ibid., 811.111 Mexico/373; Diario Oficial 28 (September 3, 1924): 11; ibid., 29 (April 17, 1925): 1873.

37. González Navarro, Población y sociedad, vol. 2, p. 208; Secretaría de Gobernación, Memorias, 1928-1929, pp. 152, 147; ibid., 1929-1930, p. 277.

38. Memorandum of January 1923 [?] in AHSRE, 36-16-318.

39. Obregón to Ponciano Carrera, February 24, 1922, Obregón papers, 822-D-2730 (quote); Obregón to Denver, Colorado Mexican colony, ibid.; Calles to Javier Cabrera, May 7, 1928, Calles papers, 217-C-121; all are illustrative of the hundreds of denials.

40. Calles to Obregón, March 7, 1923, Obregón papers, 822-C-5. 
41. Circular number 31 dated October 21, 1921, AHSRE, 2214-1 (quote); Pani to all consuls, November 1, 1922, ibid.

42. Pani to Calles, April 5, 1922, ibid., 36-16-318; Pani to Calles, December 6, 1926, Calles papers, 121-R-E-I; Luis Pérez Abreu, San Antonio consul, to Santibáñez, March 1, 1927, ibid., 241-R-F.

43. Manuel Payno, Phoenix consul, to Estrada, January 10, 1929, AHSRE, 26-1-929; Obregón to Carlos Dávila, July 24, 1924, Obregón papers, 822-C-9.

44. Payno to Estrada, January 10, 1929, AHSRE, 26-I-929.

45. Seasonal Agricultural Laborers, p. 336; New York Times, November 16, 17, 18, 23, 1922, January 31, 1923.

46. New York Times, September 17, 20, 21, 1923; Obregón to Sociedad Protectora Mexicana de Gary, Indiana, April 3, 1924, Obregón papers, 822-M-1; Secretaría de Relaciones Exteriores, Memorias, 1925-1926, p. 151 (quote).

47. Santibáñez, Ensayo, pp. 56-57; González to Estrada, January 20, 1930, AHSRE, 18-22-7.

48. Gamio, The Mexican Immigrant, p. 10.

49. Pascual Ortiz Rubio to Julio Lozano, President of the Cruz Azul Mexicana of San Antonio, December 30, 1930, Ortiz Rubio papers, 49/1123; Taylor, Mexican Labor ... Imperial Valley, pp. 61-64.

50. Gamio, Mexican Immigration, p. 132; Taylor, Mexican Labor ... Valley of the South Platte, pp. 184-85; Secretaria de Relaciones Exteriores, Memorias, 19251926, p. 149, and 1929-1930, vol. 2, p. 1712.

51. Excelsior, March 20, 1924 (quote); Francisco Alva to Obregón, December 27, 1920, Obregón papers, 805-A-1.

52. Garcia to Calles, December 2, 1927, Calles papers, 241-R-N; New York Times, April 9, 1924.

53. Obregón to Cockrell, March 24, 1923, Obregón papers, 822-F-[sic]; Estrada to Santibáñez, February 27, 1929, AHSRE, 015-73-46/1; Santibáñez, Ensayo, p. 52 and preface.

54. Memorandum of conversation between Estrada, Monnett Davis, and Mr. Morgan, Counselor of the American Embassy, February 28, 1929, RG 59, 811.111 Mexico/144; Santibáñez, Ensayo, pp. 104-05; Gamio, Mexican Immigration, pp. 184-85; idem, “Migration and Planning,"'Survey 66 (May 1, 1933): 174-75.

55. William Cochran, Mexico City vice consul, to headquarters, December 23, 1932 , RG 59, 811.111 Mexico/942 (quote and substance); Davis to Hoover, December 4, 1929, Hoover papers, "Immigration-Correspondence, 1929 April-December;" Richard Craig, The Bracero Program (Austin: University of Texas Press, 1971), passim.

\section{CHAPTER 7}

1. Vernon McCombs, From Over the Border (New York: Council of Women for Home Missions and Missionary Education, 1925), p. 136; McLean, That Mexican!, pp. 70-182. 
2. McLean, That Mexican!, pp. 64-65; McCombs, From Over the Border, pp. 77-78; Case, Thirty Years with the Mexicans, p. 242; Samuel Guy Inman, Intervention in Mexico (New York: George H. Doran Company, 1919), p. 209 (quote); Jay Stowell, The Near Side of the Mexican Question (New York: George H. Doran Company, 1921), pp. 67-69.

3. McLean and Williams, Old Spain in New America, p. 19 (first quote); Stowell, The Near Side of the Mexican Question, pp. 79 (second quote), 45-49; Case, Thirty Years with the Mexicans, p. 244.

4. Edwin Brown, "The challenge of Mexican Immigration," The Missionary Review of the World 49 (March 1926): 192-94, 196.

5. Stowell, The Near Side of the Mexican Question, pp. 80-82; McCombs, From Over the Border, p. 155; Joseph Dawson, "Among the Mexicans in Texas,"'The Missionary Review of the World 50 (October 1927): 758; J. T. Larsen, "A Needy Field,' ibid. 53 (May 1930): 364; Case, Thirty Years with the Mexicans, pp. 265, 244.

6. Robert Speer, Race and Race Relations: A Christian View of Human Contacts (New York: Fleming H. Revell Co., 1924), pp. 418 (quote), 391-92, 418-20; McLean, That Mexican!, pp. 23-24; Stowell, The Near Side of the Mexican Question, pp. 115-21.

7. McCombs, From Over the Border, pp. 124-26 (first quote); Pittsburgh Post clipping of June 4, 1923, in Obregón papers, 104-R1-E-19 (second quote).

8. Louise Shields, "Mexican Ambassadors of Good Will," The World Tomorrow 11 (February 2, 1928): 81; Investigation of Mexican Affairs, vol. 1, pp. 7, 68-69, 144; Schmitt, Mexico and the United States, p. 141; Smith, The United States and Revolutionary Nationalism, p. 156.

9. "Resolutions of the National Conference Concerning Mexicans and SpanishAmericans in the United States, December 11-16, 1926, " Calles papers, 121-RE-1; George Hinman, American Missionary Society, to Calles, January 12, 1927, ibid., 711-M-30; New York Times, December 14, 1924.

10. Gerald Shaughnessy, Has the Immigrant Kept the Faith? (New York: The Macmillan Company, 1925), pp. 221-22 (quote), 214; Gamio, Mexican Immigration, pp. $120-22$.

11. John Murphy, An Analysis of the Attitudes of American Catholics Toward the Immigrant and the Negro, 1825-1925 (Washington: The Catholic University of America Press, 1940), pp. 93-94; Shaughnessy, Has the Immigrant Kept the Faith?, pp. 259-61.

12. Taylor, Nueces County, p. 133 (quote); Carey McWilliams, North From Mexico (New York: Greenwood Press, 1968), p. 190; U.S. Congress, House, Committee on Immigration and Naturalization, Seasonal Agricultural Laborers from Mexico, 69th Congress, 1st Session, 1926), p. 265.

13. Seasonal Agricultural Laborers from Mexico, pp. 6, 62, 243 (quote); Taylor, Nueces County, p. 300; William Kirkbride, "Mexican Migration,"' The Commonwealth 21 (March 23, 1926): 14-15.

14. Temporary Admission of Illiterate Mexican Laborers, pp. 4-6, 13, 20 (quote); Seasonal Agricultural Laborers from Mexico, pp. 6, 62.

15. Seasonal Agricultural Laborers from Mexico, p. 7. 
16. Ibid., pp. 4-5, 7, 32, 88, 103; Temporary Admission of Illiterate Mexican Laborers, p. 64; Mexicans in California, pp. 153, 167, 171.

17. Comisión de Inmigración, Cámara de Comercio de los E.U., "La inmigración mexicana," in Archivo Histórico de la Secretaría de Hacienda, Mexico City; Francisco Pesquiera, Los Angeles consul, to Estrada, May 8, 1929, AHSRE, 16-V-929; Seasonal Agricultural Laborers from Mexico, p. 7 (quote).

18. Seasonal Agricultural Laborers from Mexico, pp. 42-44, 50, 52, 53-55; John Dye, Ciudad Juárez consul, to Kellogg, November 22, 1927, RG 59, 812.5611/16; San Antonio Chamber of Commerce to Kellogg, December 6, 1926, ibid., $150.126 / 151$.

19. Joan Wilson, American Business and Foreign Policy, 1920-1933 (Lexington: University of Kentucky Press, 1971), pp. 161-66; Kenneth Grieb, The Latin American Policy of Warren G. Harding (Fort Worth: The Texas Christian University Press, 1976), passim.

20. Herbert Hoover to Milton Florsheim, September 22, 1924, "Commerce Papers," Hoover papers; Alexander DeConde, Herbert Hoover's Latin-American Policy (New York: Octagon Books, 1970), p. 6 (quote); Joan Wilson, Herbert Hoover: Forgotten Progressive (Boston: Little, Brown and Company, 1975), pp. 108-09, 199-200; Joseph Tulchin, The Aftermath of War: World War I and U.S. Policy Toward Latin America (New York: New York University Press, 1971), pp. 79-81 and passim.

21. Joseph Grew, Turbulent Era: A Diplomatic Record of Forty Years, 1904-1945, 2 vols. (Boston: Houghton Mifflin Co., 1952), vol. 1, pp. 634, 638, 663; Elting Morison, Turmoil and Tradition: A Study of the Life and Times of Henry L. Stimson (Boston: Houghton Mifflin Co., 1960), pp. 314-15; Louis Ethan Ellis, Frank B. Kellogg and American Foreign Relations, 1925-1929 (New Brunswick: Rutgers University Press, 1961), p. 23; Harold Nicolson, Dwight Morrow (New York: Harcourt, Brace and Co., 1935), pp. 294-347; Robert Zieger, Republicans and Labor, 1919-1929 (Lexington: University of Kentucky Press, 1969), pp. 59-60, 63, 271-73; Meyer, Estado y sociedad con Calles, pp. 35-8, 270-5.

22. Hoover to John Raker, February 19, 1924, "Commerce papers," Hoover papers; John Dye, Commercial Attache, Mexico City Embassy to Ambassador Warren, April 5, 1924, ibid.; Weddell to Kellogg, February 11, 1925, RG 59, 811.504/282; Zieger, Republicans and Labor, pp. 83-86.

23. Morrow to Kellogg, December 13, 1928, RG 59, 812.5611/24; H. F. Arthur Schoenfield, Mexico City consul, to Kellogg, June 22, 1927, ibid., $/ 32$.

24. "Stenographic Notes of Immigration and Visa Discussions at the Consular Conference, Mexico City, October 15-19, 1937,"' RG 59, 811.111 Mexico/1261. This conference was a review of policy in the 1920s. See also Higham, Strangers in the Land, pp. 313-15.

25. Stenographic Notes of Immigration and Visa Discussions.

26. Everett Drumwright, vice consul Ciudad Juárez, to headquarters, September 3, 1931, ibid., /665; Davis to Cole, April 15, 1925, in Congressional Record (January 6, 1925): 1366-67; Report of the Secretary of Labor, 1926, p. 113; Congressional Record (April 15, 1926): 5878-79; Martínez, Border Boom Town, pp. 66-7.

27. W. R. Mansfield, District Director Immigration Service, Denver, Colorado, to 
Husband, August 8, 1924, RG 85, 4007/1; Mansfield to Caminetti, February 4, 1921, ibid., 54261/202; Husband to Rep. Thomas Blanton, April 5, 1922, ibid., 55091/6; Robe White, Assistant Secretary of Labor, to W. T. Mathews, District Attorney, Elko, Nevada, April 13, 1923, ibid., 55091/8.

28. Interview with E. J. Walker, former employee of the Arizona Cotton Growers Association, April 30, 1929, Taylor, “Unpublished Field Notes,"'pp. 497-98.

29. Edwin Keith, Acting Chief of the Division of Mexican Affairs of the Department of State, to Manuel Tellez, First Secretary of the Mexican Embassy, September 15, 1921, RG 59, 150.123/15a; Sokobin to Stimson, July 11, 1932, ibid., 811.111 Mexico/852.

30. Samuel Gompers, "America Must Not Be Overwhelmed," American Federationist 29 (November 1924): 313-14; Harvey Levenstein, "The AFL and Mexican Immigration in the 1920's: An Experiment in Labor Diplomacy," Hispanic American Historical Review 48 (May 1968): 207-09; U.S. Congress, Senate, Committee on Immigration, Restriction of Western Hemisphere Immigration, 70th Congress, Ist Session, 1928, p. 9.

31. Commissioner General of Immigration, Annual Report, 1927, pp. 185-188; Annual Report, 1929, p. 16; New York Times, December 3, 1928.

32. Max Handman, "The Mexican Immigrant in Texas," Proceedings (National Conference of Social Work) 53 (1926): 334; Theodore Roosevelt, "Immigration," National Republic 17 (1929): 34; Seasonal Agricultural Laborers from Mexico, pp. 297, 344.

33. Garis, Immigration Restriction, pp. 203-04; Benjamin Keen, The Aztec Image in Western Thought (New Brunswick: Rutgers University Press, 1971), p. 381; Marvin Harris, The Rise of Anthropological Theory (New York: Thomas Y. Crowell Co., 1968), pp. 118-41.

34. C. M. Goethe, "Immigration from Mexico," in Madison Grant and Charles Davison (eds.), The Alien in Our Midst or "Selling Our Birthright for a Mess of Pottage" (New York: The Galton Publishing Co., Inc., 1930), pp. 140-41; Frederick Burnham, "The Howl for Cheap Mexican Labor," ibid., p. 45; Albert Johnson, “The Opponents of Restricted Immigration," ibid., p. 10; Mark Reisler, "Always the Laborer, Never the Citizen: Anglo Perceptions of the Mexican Immigrant During the 1920s, " Pacific Historical Review 45 (May 1976): 231-54 gives a lengthy catalog of stereotypes.

35. Madison Grant, The Passing of the Great Race, or the Racial Basis of European History (New York: Charles Scribner's Sons, 1916), pp. 15, 69, 80-81, 150.

36. Robert Foerster, The Racial Problems Involved in Immigration from Latin America and the West Indies to the United States (Washington: GPO, 1925), pp. 13-14, 48, 60-61; C. M. Goethe, "Peons Need Not Apply,"'World's Work 59 (November 1930): 165-70; Glenn Hoover, "Our Mexican Immigrants," Foreign Affairs 8 (October 1929): 104.

37. Foerster, The Racial Problems Involved in Immigration from Latin America and the West Indies to the United States, pp. 43, 46 (quote); Theodore Lathrop Stoddard, The Rising Tide of Color Against White World-Supremacy (New York: Charles Scribner's Sons, 1920), pp. 107-08; idem, Re-Forging America: The Story of Our Nationhood (New York: Charles Scribner's Sons, 1927), p. 258.

38. Stoddard, Re-Forging America, p. 216 (quotes); Stoddard, The Rising Tide of Color, p. 220; Temporary Admission of Illiterate Mexican Laborers, pp. 6, 303. 
39. Chicago Daily Tribune, May 13, 1925, clipping in Calles papers, 721-S-39; Cruz Zabala to Obregón, August 24, 1924, Obregón papers, 104-T-10; Remsen Crawford, "Six Years of Immigrant Quotas," Saturday Evening Post 200 (October 29, 1927): 122; Stoddard, Re-Forging America, pp. 258-60.

40. Quoted in Acuña, Occupied America, p. 140.

41. Harvey Levenstein, Labor Organizations in the United States and Mexico: A History of Their Relations (New York: Greenwood Publishing Co., 1971), pp. 55-57, 98 (quote).

42. Levenstein, "The AFL and Mexican Immigration in the 1920's," pp. 209-19.

43. Annual Report of the Secretary of Labor, 1923, pp. 61, 105, 170, 175; Higham, Strangers in the Land, p. 325; Levenstein, Labor Organizations in the United States and Mexico, pp. 99-100.

44. Rep. Adolph Sabath to President Harding, May 17, 1921, Harding papers, roll 178, file 114; Rufus Tucker, Bureau of Foreign and Domestic Commerce, to Hoover, February 14, 1924, "Commerce papers," Hoover papers; Congressional Record (April 18, 1924): 6621, 6623-24, 6630.

45. "Foreword" in Garis, Immigration Restriction, p. viii.

46. Congressional Record (May 23, 1928): 9609; John Box, Imported Pauper Labor (Washington: GPO, 1921), passim.

47. Charles Howland, Survey of American Foreign Relations (New Haven: Yale University Press, 1931), pp. 225-26; Jones, American Immigration, pp. 262-65, 269-70, 276-77; Madison Grant, "America for the Americans," Forum 74 (September 1925): 346-55; Roy Garis, "National Origins and Deportations," Scribner's Magazine 83 (January 1928): 52-56.

48. Seasonal Agricultural Laborers from Mexico; Restriction of Western Hemisphere Immigration; U.S. Congress, House, Committee on Immigration and Naturalization, Immigration from Mexico, 71st Congress, 2nd Session, 1930; ibid., Western Hemisphere Immigration; ibid., Immigration From Countries of the Western Hemisphere.

49. Commissioner General of Immigration, Annual Report, 1927, pp. 185-87; idem, Annual Report, 1929, p. 16; idem, Annual Report, 1930, p. 17; Annual Report of the Secretary of Labor, 1928, pp. 135-44; New York Times, May 13, 1926, and December 3, 1928.

50. Kellogg to Coolidge, July 21,1927 , Coolidge papers, file 133, reel 79; Coolidge to Davis, July 25, 1927, ibid., file 20D, reel 20; Davis to Coolidge, July 29, 1927 , ibid.

51. Immigration from Mexico, p. 3; Davis to Hoover, April 29, 1929, "Presidential Papers, Immigration Correspondence, 1929 April-December," Hoover papers; Levenstein, Labor Organizations in the United States and Mexico, p. 125; New York Times, March 6, 1928.

52. Kellogg to Coolidge, February 13, 1928, and April 10, 1928, Coolidge papers, file 133 , reel 79.

53. El Universal, December 18, 1928; Excelsior, March 3, 1928; New York Times, May 19 and 20, 1929.

54. Morrow to Kellogg, November 15, 1927, RG 59, 812.5611/11; Kellogg to Morrow, July 5, 1928, ibid., 811.111 Mexico/82. 
55. Monnett Davis to Carr, April 10, 1928, ibid., /36 1/2.

56. Western Hemisphere Immigration, p. 28; John Simmons, Chief of Visa Division, to William Dawson, Consul General, December 30, 1929, RG 59, /305 1/2.

57. Maurice Altaffer, Nogales consul, to Kellogg, September 12, 1929, ibid., /272; Johnson to Hoover, July 13, 1929, "Presidential Papers, Immigration Correspondence, 1929 April-December," Hoover papers; El Universal, May 29, 1929; New York Times, July 3, 1929.

58. Alejandro Lubbert, Consul General, to Estrada, October 16, 1929, AHSRE, 4-Y1-919; Plutarco Calles, Informe rendido ante el Congreso de la Unión el I de septiembre de 1928 (Mexico: Talleres Gráficos de la Nación, 1928), p. 26; El Universal, February 3, 1930.

59. Congressional Record (February 16, 1929): 3614-21; Arthur F. Corwin, "A Story of Ad Hoc Exemptions: American Immigration Policy Toward Mexico," in Corwin (ed.), Immigrants - and Immigrants, pp. 146-48.

60. Hull to all personnel, April 6, 1929, RG 85, 55598/496; Richard Boyce, Nuevo Laredo consul, to Kellogg, November 1, 1929, RG 59, 811.111 Mexico/285.

61. Congressional Record (April 21, 1930): 7325 (quote); ibid. (May 13, 1930): $8841-44$.

62. Robert Divine, American Immigration Policy, 1924-1952 (New Haven: Yale University Press, 1957), pp. 65-66.

\section{CHAPTER 8}

1. William E. Leuchtenburg, The Perils of Prosperity, 1914-32 (Chicago: University of Chicago Press, 1958), pp. 247-48, 254; Joseph Dorfman, The Economic Mind in American Civilization, 5 vols. (New York: The Viking Press, 1946-59), vol. 5, p. 621; Murray Rothbard, America's Great Depression (Princeton: Van Nostrand, 1963), p. 290.

2. Ignacio Batiza, Detroit consul, to Tellez, March 7, 1930, AHSRE, 73-14/17. IV-76-3; Jose Bejarano, Mexican Commercial Agent in New York City, to Luis León, Secretary of Industry, April 5, 1930, Ortiz Rubio papers, 2/217/47766; Leuchtenburg, The Perils of Prosperity, p. 252; Abraham Hoffman, Unwanted Mexican Americans in the Great Depression: Repatriation Pressures, 1929-1939 (Tucson: University of Arizona Press, 1974), pp. 120-22; Mercedes Carreras de Velasco, Los mexicanos que devolvió la crisis 1929-1932 (Mexico: Secretaría de Relaciones Exteriores, 1974), pp. 58-59.

3. González to Secretary Tellez, January 1, 1932, AHSRE, 41-26-139; Santibáñez to all consuls, October 27, 1930, ibid., 73-46-32; Santibáñez to Estrada, October 25, 1930, ibid., 73-84-1; González to Ortiz Rubio, April 4, 1932, Ortiz Rubio papers, 250; Martínez, Border Boom Town, pp. 80-82, 89-90.

4. Quoted in Taylor, "Songs of the Mexican Migration," pp. 232-33.

5. Ray Wilbur and Arthur Hyde, The Hoover Policies (New York, Charles Scribner's Sons, 1937), p. 144; Call Bulletin editorial, July 31, 1930, in Hoover papers, "Immigration-Clippings 1930," and passim for other clippings. 
6. Charles Visel to Wilson, March 19, 1931, RG 59, 811.55739/674; Carr to Hull, June 17, 1930, ibid.; Hoffman, Unwanted Mexican Americans, pp. 39-48.

7. Quoted in Taylor, "Songs of the Mexican Migration," pp. 234-35.

8. Carey McWilliams, "Getting Rid of the Mexicans," American Mercury 28 (March 1933): 322-24; Norman D. Humphrey, "Mexican Repatriation from Michigan: Public Assistance in Historical Perspective," Social Service Review 15 (September 1941): 497-513; Hoffman, Unwanted Mexican Americans, pp. 116-17 and passim.

9. Dwyre to Henry L. Stimson, Secretary of State, July 20, 1934, RG 59, 811.111 Mexico/141; Robert McLean, "Goodby, Vicente!,' Survey 66 (May 1, 1931): 182; Divine, American Immigration Policy, p. 77; Hoffman, Unwanted Mexican Americans, p. 126; Moisés González Navarro, "Efectos sociales de la crises de 1929,' Historia Mexicana 18 (abril-junio, 1970): 536-58; Commissioner General of Immigration, Annual Report, 1931, p. 9.

10. J. Reuben Clark to Stimson, February 20, 1931, RG 59, 150.126/245; Carreras de Velasco, Los mexicanos que devolvió la crisis, p. 74.

11. Pesquiera to Estrada, June 2, 1931, AHSRE, IV-362-46; Estrada to Rafael de la Colina, Los Angeles consul, May 11, 1931, ibid., IV-339-18.

12. Robinson to Hill, April 12, 1932, ibid., IV-549-1.

13. Letters and telegrams between Martínez and other parties, ibid., IV-360-28.

14. José Puig Casauranc, Mexican Ambassador, to Stimson, November 23 and December 2, 1931, ibid., 32-76-29; Eduardo Villaseñor, Chief of Consular Department, to Puig, November 12, 1931, ibid.

15. Tellez to Santibáñez, May 21, 1932, ibid., IV-361-25; Carreras de Velasco, Los mexicanos que devolvió la crisis, p. 98; Hoffman, Unwanted Mexican Americans, pp. $139-40$.

16. Colina to Tellez, March 13, 1932, AHSRE, IV-549-1; Fernando Alatorre, San Bernardino consul, to Estrada, ibid., IV-362-46; Los Angeles La Opinión clipping of October 28, 1932, ibid., IV-549-1.

17. James C. Gilbert, "A Field Study in Mexico of the Mexican Repatriation Movement" (Master's thesis, Department of Sociology, University of Southern California, 1934), pp. 62, 69 (quotes); Carreras de Velasco, Los mexicanos que devolvió la crisis, pp. 135-38; Meyer, El conflicto social, pp. 35, 83-88, 173-210.

18. Quoted in Taylor, “Songs of the Mexican Migration," p. 236. 



\title{
BIBLIOGRAPHIC ESSAY
}

\author{
Primary Sources
}

\section{Manuscript collections}

There were several research limitations to this study. I was denied access to the Department of Migration archives which are located in the Ciudadela in Mexico City. The Secretariat of Interior, through its Department of Migration, was responsible for all matters related to the entry and exit of Mexicans at frontier points. This was only a small part of its jurisdiction. Interior was also charged with vigilance over such politically sensitive matters as public order, press censorship, elections and candidate certification, organized religion, and the adherence of local, state, and federal officials to the rights and duties of their offices. It was also responsible for the implementation of all presidential decrees. The legal and moral shortcomings of shaky revolutionary governments are, in all probability, documented in this archive. It is doubtful that any investigator will be allowed to see these files as long as federal governments claim to be the legitimate heirs of the Revolution of 1910 .

I was also denied access to the records of several major corporations which employed thousands of Mexican workers prior to the Great Depression. My letters to more than twenty companies were not answered for the most part; the few responses received stated there were no archives available for public scrutiny. Perhaps, with the passage of time, historians may be able to carry out their investigations in the files of some of these organizations.

Despite these limitations, the materials described below were sufficient enough in quantity and quality to write the history of Mexican emigration from 1897 to 1931. 


\section{MEXICO}

The Archivo Histórico de la Secretaría de Relaciones Exteriores (AHSRE) was the richest source for this study. By 1940 the Mexican government maintained more than fifty consular districts in the United States and had sponsored the investigations of hundreds of other special diplomatic and commercial agents in the neighboring country. Personnel employed in these posts grew steadily from the turn of the century, and their reports remitted to the Secretary of Foreign Relations in Mexico City amount to hundreds of thousands of documents now in the AHSRE.

There are several catalogs in the archive to help locate materials. There is a name index to find reports by individual consuls or agents as well as by the thousands of emigrants and their children who contacted them. A geographic index is indispensable for obtaining materials that relate to a specific locale. A chronological guide gives the decimal numbers for documents according to the date they were written. Lastly, Berta Ulloa's Revolución Mexicana, 1910-1920 (Mexico: Secretaría de Relaciones Exteriores, 1963) provides a valuable, thorough guide to the 259 volumes which constitute the set entitled "Ramo de la Revolución Mexicana." Although this collection does not deal primarily with emigration matters, it does contain scattered documents, especially newspaper clippings, reporting on Mexicans in the United States.

Decimal file IV/524 contains almost all AHSRE materials pertaining to emigrants and government efforts to deal with the problem. These firsthand reports not only refer to Mexican citizens but also attempt to describe the situations where bracero labor contributed to the development of the American economy. There are countless, more restricted studies which can be based upon these materials. State and local studies of expatriate communities are two of the most obvious.

The Obregón-Calles papers in the Archivo General de la Nación in Mexico City were next in importance as sources for this study. The papers of the two leaders, totaling 226 large bundles, are physically bound together in two series. The first and larger series has far more documents from the Obregón administration (1920-24) than from Calles's reign (1924-28). In "Series A" there are 2 bundles; none of the documents have a decimal number. No reliable index exists for the Obregón-Calles papers, and one must patiently wade through them one by one. My "The Presidential Papers of Alvaro Obregón (1920-1924) and Plutarco Elías Calles (19241928 ) in the Archivo General de la Nación, Mexico City," The Americas, 37 (1980) is an attempt to provide future scholars with a general guide to these papers.

Scattered throughout the Obregón-Calles papers, and especially in bundles 1 to $2-1,7-1$ to 8,63 to $66-1,73$ to $88-1$, and $112-1$ of the main series, are thousands of letters from citizens, many of them in the United States. These 
letters-often replete with poor spelling and bad grammar-provide a poignant source of the hopes, fears, and feelings of members of the Mexican lower class. The simplicity and clear exposition of motives for emigration found in these writings have provided a crucial element for this study. The social historian of twentieth century Mexico who taps this largely unused source will go far in aiding our understanding of the Revolution and its aftermath.

Bundle number 112-1 in the larger set, where most of the documents bear file number $822-\mathrm{M}-1$, is the largest concentration of governmental documents regarding emigration. Bundles 1-0 and 1-Y of Series $A$ have many materials dealing with the status and protection of expatriate Mexicans. Both Presidents Obregón and Calles had a keen interest in the labor exodus, and the proof of that interest lies in their papers; hundreds of other sources, scattered throughout their papers without any apparent plan, provided further documentation.

Papers of other presidents in the Archivo General de la Nación were a disappointment. By far the most complete set was that of Emilio Portes Gil, provisional president from 1928 to 1929 . His archive, a jumbled mass without order, consists of forty bundles with only scattered materials of interest. What little remains of the papers of Pascual Ortiz Rubio (1929-32) and Abelardo Rodríguez (1932-34) was of little value. It is hoped that the new ordering and care of the priceless treasures of the Archivo General, as reported in its Boletín, 3rd series, vol. 1 (abril-junio 1977), will proceed apace.

The last collection was that of Venustiano Carranza, president from 1917 to 1920. His papers, assembled in notebooks and placed in chronological order, are housed in the library of Condumex, S.A., in the northern industrial section of Mexico City. They contain only incidental information for emigration but did have a great deal of correspondence relating to the social and economic ills which beset Mexico during the first decade of the Revolution. This set, like those of other chief executives, lacks almost entirely all materials bearing on personal matters and politically sensitive affairs. Family members or political associates may well have these archives. If ever made accessible to researchers, they will surely open many new vistas in our understanding of modern Mexico.

\section{UNITED STATES}

American political leaders were important in determining the fate of emigration. I consulted documents of many members of the Woodrow Wilson administration for explanations of policy toward Mexican immigrants during the 1913-21 period. The Library of Congress microfilm edition of the Calvin Coolidge papers, the Warren G. Harding microfilmed papers (Ohio Historical Society), and the Herbert Hoover papers maintained by the National Archives and Records Service in West Branch, Iowa, had few documents on emigration. But what was in these three presidential archives was pivotal to understanding policymaking at the highest levels of the federal government. 
The richest documentation came from the records of the federal agencies which dealt with the emigrants on a day-by-day basis. Department of State documents in the National Archives Record group 59 either in Washington, D.C., or at the Federal Records Center in Suitland, Maryland, fall into four major categories. Decimal file 150, Visa Division, Correspondence Regarding Immigration, 1910-39, has scattered materials on Mexican immigration from the general public as well as a few consular reports. File number 811 , Department of State Decimal File, 1910-29, provided the bulk of information in the form of many consular reports based on day-by-day observation of the emigrants as they trekked toward the United States. Documents in file $811 \ldots$ Mexico/, contained diplomatic correspondence from high level officials such as the Consul General and Ambassador and provided digests of monthly consular reports to the Embassy in Mexico City. File 812, Records of the Department of State Relating to the Internal Affairs of Mexico, 1919-29, has a disappointingly small amount of relevant material given the preoccupation of American officials with such matters as oil and political developments. Record Group 85, Records of the Immigration and Naturalization Service, was an important repository for understanding public reaction to Mexican immigration, the working out to final form of the 1917-21 waivers, and the effects of the postwar recession.

\section{Published documents}

There is no volume of published primary sources dealing with emigration per se, despite the need for such a research tool. One must comb through more general publications for illustrative materials. The work edited by Jesús Silva Herzog, La cuestión de la tierra (4 vols.; Mexico: Instituto de Investigaciones Económicas, 1960-62), is a gold mine of rare pamphlets and speeches which deal with the land problem during the earliest phases of the Revolution. The following collections deal largely with the political manifestations of the Revolution as they affected Mexico: Isidro and Josefina Fabela et al. (eds.), Documentos históricos de la Revolución mexicana (27 vols.; Mexico: various publishers, 1964-76); and Manuel González Ramírez (ed.), Fuentes para la historia de la Revolución mexicana (4 vols.; Mexico: Fondo de Cultura Económica, 1954-57).

Official statements of policy are best found in the Memorias, or annual reports, of concerned Mexican governmental agencies. This is particularly true for the Secretaries of Interior and Foreign Relations. The Diario Oficial reports the actions and plans of the executive branch of the government. The Annual Reports of the Secretaries of Labor, Commerce, and the Commissioner General of Immigration of the American government are more meaningful in detail and also include rationale for policy to a far greater degree than is true in the publications of their Mexican counterparts. 


\section{Contemporary accounts}

Contemporary chroniclers provided an important source of information for this study. The divisiveness of opinion concerning the presence of Mexican workers in the United States caused many official committees, scholars, and other interested people to take to the fields, mines, railroads, and hearing rooms in attempts to judge the matter for themselves. Congressional concern gave rise to many hearings. The most valuable of these for the pros and cons on the issue include U.S. Congress, House Committee on Immigration and Naturalization, Temporary Admission of Illiterate Mexican Laborers (hearings on the extension of the wartime waivers), 66th Congress, 1st Session (Washington: GPO, 1920); idem, Seasonal Agricultural Laborers from Mexico, 69th Congress, 1st Session (Washington: GPO, 1929); idem, Immigration From Mexico, 71st Congress, 2nd Session (Washington: GPO, 1930); U.S. Congress, Senate Committee on Immigration, Restriction of Western Hemisphere Immigration, 70th Congress, 1st Session (Washington: GPO, 1928). The Fall Committee hearings, U.S. Congress, Senate Committee on Foreign Relations, Investigation of Mexican Affairs, 66th Congress, 2nd Session (Washington: GPO, 1920), although heavily weighted with testimony unfavorable to the revolutionaries, has much firsthand information regarding labor contracting, Protestant missionary attitudes, and conditions of anarchy.

Other government publications of value include volume 25 of U.S. Congress, Senate, Report of the United States Immigration Commission (42 vols.; Washington: GPO, 1911), where the belief in the benign nature of Mexican immigration is best expressed. Robert Foerster's The Racial Problems in Immigration from Latin America and the West Indies to the United States (Washington: GPO, 1925) is a restrictionist argument originally submitted in report form to Secretary of Labor Davis and later circulated in an attempt to affect public opinion. Two articles published in 1908 complement each other well: Victor S. Clark, "Mexican Labor in the United States," Bulletin of the United States Bureau of Labor, 78 (September 1908), a relatively dispassionate account of immigrants who had gone as far as Wyoming and Kansas at the time of publication; and Walter Weyl, "Labor Conditions in Mexico," ibid. (January 1908). In the Congressional Record for the period there are a number of pages devoted to the immigrants, but one must be careful not to rely on the series' inadequate index. The twelfth through fifteenth census reports (1900-30) provide much needed data, despite their often obvious inaccurate information. Not to be overlooked is the unique state assessment found in California: Report of Governor C. C. Young's Mexican Fact-Finding Committee, Mexicans in California (San Francisco: Department of Industrial Relations, 1930).

Special mention must be made of the works of Paul S. Taylor and Manuel Gamio. Most of economist Taylor's writings were published under the general 
title of Mexican Labor in the United States, and they contain extensive field observations which detail conditions of labor, housing patterns, and American attitudes, to mention only a few of the topics in these works. They include Imperial Valley, California, University of California Publications in Economics, VI, number 1 (Berkeley, 1928); Valley of the South Platte, Colorado, ibid., number 2 (Berkeley, 1929); Dimmit County, Winter Garden District, South Texas, ibid., number 5 (Berkeley, 1930); Chicago and the Calumet Region, ibid., VII, number 2 (Berkeley, 1932). The same author's $A$ Mexican-American Frontier: Nueces County, Texas (Chapel Hill: University of North Carolina Press, 1934), A Spanish-American Peasant Community: Arandas in Jalisco, Mexico (Berkeley: University of California Press, 1933), and "Songs of the Mexican Migration," in J. Frank Dobie (ed.), Puro Mexicano (Austin: Texas Folklore Society, 1935), amplify information in the Mexican Labor in the United States series. Taylor's care, precision, and disinterested approach have resulted in a large number of primary documents which will provide standard fare for historians for many years to come.

Gamio's two most important works are Mexican Immigration to the United States (Chicago: University of Chicago Press, 1930) and The Mexican Immigrant: His Life Story (Chicago: University of Chicago Press, 1931). The latter contains parts of interviews carried out in 1926 and 1927 with fiftyseven immigrants in many parts of the United States. The larger part of the field notes collected by Gamio and his staff were deposited with the Social Science Research Council, the sponsoring agency for both books. These documents would provide invaluable information on the larger trends of assimilation and social mobility in the immigrant community. The former study is a synthesis of all the interviews. It provides an in-depth study of conditions in the late 1920s as well as Gamio's conclusions.

The more polemical but still useful literature of the period includes Roy Garis's Immigration Restriction (New York: Macmillan, 1927), the classic nativist statement, and Alfonso Fábila's El problema de la emigración de obreros y campesinos mexicanos (Mexico: Talleres Gráficos de la Nación, 1929), equally opposed to emigration but for different reasons of national pride. Andrés Landa y Piña, in El Servicio de Migración en México (Mexico: Talleres Gráficos de la Nacion, 1930) presents another defense of the failures of various Mexican governments to deal with the labor exodus. Gilberto Loyo, in Emigración de mexicanos a los Estados Unidos (Rome: Instituto Poligráfico dello Stato, 1931), makes a short (15-page) plea for a propopulationist policy which was not attempted until the administration of President Lázaro Cárdenas (1934-40). Missionary writings were generally favorable to Mexican immigration and espoused an environmentalist explanation of cultural differences. Two examples of this genre include: Robert McLean, That Mexican! (New York: Revell \& Co., 1928), and Vernon McCombs, From Over the Border (New York: Council of Women for Home Missions and Missionary Education, 1925). 
Three contemporary studies are crucial to an understanding of rural poverty as a stimulus for emigration. The classic Los grandes problemas nacionales (Mexico: Instituto Nacional de la Juventud Mexicana, 1964), originally published in 1909, presents Andrés Molina Enríquez's clear exposition of all that was rotten in rural Mexico on the eve of the Revolution. $L a$ población del Valle de Teotihuacán (3 vols.; Mexico Secretaría de Educación Pública, 1922) by Manuel Gamio et al. is a unique field study which provides factual data for generalizations regarding rural peoples. George McBride's The Land Systems of Mexico (New York: American Geographical Society, 1923 ) is a convenient source in English of agrarian developments, although the author did not sense the implications of peasant demands for the restitution of their ejidos.

\section{Secondary Works}

\section{General}

We lack an adequate historical synthesis of twentieth century Mexico owing to the lack of solid monographic studies. Charles Cumberland's Mexico: The Struggle for Modernity (New York: Oxford University Press, 1968) is now outdated. La Revolución social de México (3 vols.; Mexico: UNAM, 1960), by Manuel González Ramírez, is also dated but gives an adequate description of the social concerns of political leaders. David C. Bailey, in "Revisionism and the Recent Historiography of the Mexican Revolution," Hispanic American Historical Review, 58 (February 1978), points out some of the many lacunae of the field.

Porfirian Mexico has been given a much overdue analysis in the history by Daniel Cosío Villegas et al.: Historia moderna de México (9 vols.; Mexico: Editorial Hermes, 1955-72). Based principally on published sources, this set provides many insights into the hitherto misunderstood complexities of turn-of-the-century Mexico and raises a multitude of further research possibilities. Moisés González Navarro's La colonización en México, 1877-1910 (Mexico: Colegio de México, 1960) is an extensive treatment of rural changes and the government policy which motivated them. The Estadisticas económicas del Porfiriato (Mexico: Colegio de México, n.d.) is a convenient collection of extant data from census reports and other sources, especially since the census of 1895; Friedrich Katz's article, "Labor Conditions on Haciendas in Porfirian Mexico: Some Tendencies," Hispanic American Historical Review, 54 (February 1974), is the necessary starting point for the scholar of rural developments.

Post-1910 Mexican history has drawn the attention of surprisingly few researchers. Clark Reynolds, in The Mexican Economy (New Haven: Yale University Press, 1970), provides the contours of general economic growth in terms a layman can understand. Moisés González Navarro's work, Población y sociedad en México (1900-1970) (2 vols.; Mexico: UNAM, 1974), stresses 
social changes in the twentieth century. The convoluted history of agrarian reform, long lacking an update by scholars, is best dealt with by Jesús Silva Herzog in El agrarismo mexicano y la reforma agraria (2nd ed.; Mexico: Fondo de Cultura Económica, 1959). Two excellent local studies of rural communities, which, it is hoped, will be models for others like them, are: Luis González y González, San José de Gracia: Mexican Village in Transition, trans. John Upton (2nd ed.; Austin: University of Texas Press, 1974); and Paul Friedrich, Agrarian Revolt in a Mexican Village (Englewood Cliffs: Prentice-Hall, 1970), a study of the ejido and its inhabitants in Naranja, Michoacán.

Political developments are dealt with in most general works. John W. F. Dulles's Yesterday in Mexico (Austin: University of Texas Press, 1961) is a chronicle of the 1919-36 period with no attempt at synthesis. For the most part, we even lack sound biographies of the presidents of revolutionary Mexico. There are outstanding exceptions: Charles Cumberland's Mexican Revolution: Genesis Under Madero (Austin: University of Texas Press, 1952) and Stanley R. Ross's Francisco I. Madero: Apostle of Mexican Democracy (New York: Columbia University Press, 1955), both provide excellent coverage of the period from 1904 to 1913. Michael C. Meyer, Huerta: A Political Portrait (Lincoln: University of Nebraska Press, 1972) ably unravels the history of the much misunderstood 1913-16 period. Cumberland's Mexican Revolution: The Constitutionalist Years (Austin: University of Texas Press, 1972), the second volume of his uncompleted trilogy, carries the political story up to 1920 . After the latter date, we enter what is largely a scholarly desert. Merle Simmons's The Mexican Corrido as a Source for Interpretive Study of Modern Mexico (Bloomington: Indiana University Press, 1957) is a yeoman effort to survey the opinions of the lower classes as expressed in their news medium, the folk song. The Colegio de México's projected 23 volume Historia de la Revolución mexicana, initiated by the late Daniel Cosio Villegas, has two volumes which were useful here because of the extensive research and tempered judgments of the authors: Lorenzo Meyer's El conflicto social y los gobiernos del Maximato (Mexico: El Colegio de México, 1978) and Jean Meyer's Estado y sociedad con Calles (Mexico: El Colegio de México, 1977). This series will doubtlessly serve the same didactic function as Cosío Villegas' earlier multi-volume set on the Porfiriato.

Numerous studies by competent scholars deal with the development of the recent West. Gary Nash, in The American West in the Twentieth Century (Englewood Cliffs: Prentice-Hall, 1973), and Harold Barger and Hans H. Landsberg, in American Agriculture, 1899-1939 (New York: National Bureau of Economic Research, 1942), provide a wealth of information regarding the economic and demographic trends of the area. Donald Meinig, in Southwest: Three Peoples in Geographical Change, 1600-1970 (New York: Oxford University Press, 1971), approaches the same themes from a different perspective. 
Historians have subjected the tribal twenties to close scrutiny. The fresh approaches of Joan Hoff Wilson, in Herbert Hoover: Forgotten Progressive (Boston: Little, Brown, and Co., 1975), and Robert Zieger, in Republicans and Labor, 1919-1929 (Lexington: University of Kentucky Press, 1969), have provided valuable points of departure for this study. John Higham's Strangers in the Land: Patterns of American Nativism, 1860-1925 (New Brunswick: Rutgers University Press, 1955) still remains the best account of this important trend in American history.

\section{Diplomatic histories}

There is no single account of the diplomacy of Mexican immigration to the United States. Nor is there much mention of the population movement in any of the more general works. The best account is Robert Freeman Smith's The United States and Revolutionary Nationalism in Mexico, 1916-1932 (Chicago: University of Chicago Press, 1972). Revisionist perspectives for the 1920s include the following works: Kenneth Grieb, The Latin American Policy of Warren G. Harding (Fort Worth: The Texas Christian University Press, 1976); and Joan Hoff Wilson, American Business and Foreign Policy, 1920-33 (Lexington: University of Kentucky Press, 1971). Much general information on personalities and policies may be gained from Louis Ethan Ellis's Frank B. Kellogg and American Foreign Relations, 1925-1929 (New Brunswick: Rutgers University Press, 1961). Atypical within this category is Harvey Levinstein's Labor Organizations in the United States and Mexico: A History of their Relations (New York: Greenwood Press, 1971), in which the author's careful research details efforts of union leaders to resolve the conundrum of labor emigration.

\section{Other accounts of emigration}

There are two major attempts to write the history of emigration before the Great Depression. An unrevised Ph.D. dissertation from 1957 has been reprinted: John Martinez, Mexican Emigration to the U.S. 1910-1930 (San Francisco: R and E Research Associates, 1971). For this pioneering effort, the author did not have access to Mexican archives, which has led to an uncritical and unmerited acceptance of the rhetoric of various Mexican leaders. Nor does the author make more than brief mention of the root causes of emigration before 1910. Mark Reisler's By the Sweat of Their Brow: Mexican Immigrant Labor in the United States, 1900-1940 (Westport: Greenwood Press, 1976) is based on extensive research in the National Archives in Washington, D.C., but neglects available Mexican resources. This second study, as the title indicates, is more a view of ethnic relations and labor patterns than it is a survey of causes of emigration; one must use Reisler's conclusions with care.

Other published works are indicated in Arthur F. Corwin's article, "Mexican Emigration History, 1900-1970: Literature and Research,' Latin American Research Review, 7 (Summer 1973). Of great value for this study were: 
Ernesto Galarza, Barrio Boy (Notre Dame: University of Notre Dame Press, 1971), the memoirs of an emigrant; and Rosalio Moisés, The Tall Candle (Lincoln: University of Nebraska Press, 1971), in which there are recorded conversations with a Yaqui Indian who worked from time to time in the United States. The publication of similar reminiscences would provide a very fertile source for future research. This need is partially met by James $C$. Gilbert in "A Field Study in Mexico of the Mexican Repatriation Movement," an unpublished Master's thesis from 1934, written for the Department of Sociology at the University of Southern California. Other repatriation studies include: Abraham Hoffman, Unwanted Mexican Americans in the Great Depression: Repatriation Pressures, 1929-1939 (Tucson: University of Arizona Press, 1974), a model study which concentrates on the Los Angeles area; and Mercedes Carreras de Velasco, Los mexicanos que devolvió la crisis, 1929-1932 (Mexico: Secretaría de Relaciones Exteriores, 1974), a less satisfactory study which attempts to show the reaction of the Mexican government to the repatriation movement.

Several additional studies lend a deeper understanding to the dynamics of emigration. Robert Divine, American Immigration Policy, 1924-1952 (New Haven: Yale University Press, 1957) is valuable for its analysis of the late 1920s. Maldwyn Allen Jones, in American Immigration (Chicago: University of Chicago Press, 1960), gives a broader perspective on the history of immigration throughout the development of the United States. There is also Carey McWilliams's North From Mexico (New York: Greenwood Press, 1968), a reprint of a 1948 book; although written by a crusading journalist it has many insights to offer the scholar who wishes to study the Mexican in this country. A rare survey of newspaper opinion is given by Moisés González Navarro in “'Los braceros en el Porfiriato,"' Estudios Sociológicos del Quinto Congreso Nacional de Sociología, vol. 5, tomo segundo (1954).

A few scholarly accounts deal with the impact of Mexican immigration on established communities and institutions. Oscar J. Martínez's Border Boom Town: Ciudad Juárez Since 1848 (Austin: University of Texas Press, 1978) shows the important role played by immigrants in the development of the Ciudad Juárez-El Paso region. "Obreros: The Mexican Workers of El Paso, 1900-1920," a Ph.D. dissertation by Mario Trinidad Garcia, provides an in-depth look at one city, and Ricardo Romo's dissertation, "Mexican Workers in the City: Los Angeles, 1915-1930" provides a study of another urban area. Kaye Lynn Briegel's "Alianza Hispano-Americana, 1894-1965: A Mexican American Fraternal Insurance Society," a third dissertation, gives a unique insight into attempts by minority group members to cope with the larger majority. Arthur F. Corwin's edited book Immigrants-and Immigrants: Perspectives on Mexican Labor Migration to the United States (Westport: Greenwood Press, 1978) has much information and is pregnant with suggestions for further research. 


\section{Newspapers}

The central repository for newspapers in Mexico is the Hemeroteca in Mexico City. El Imparcial was anything but impartial as it shifted its opinion in close accord with the dictates of the Díaz government. El País was a Catholic organ which did its best to subject emigration to a searching analysis, much to the displeasure of Porfirian officials. For the post-1910 period $E l$ Universal and Excelsior, despite a generally pro-government stance on most issues, both evinced editorial concerns about the dangers of emigration. Scattered copies of El Paso del Norte, which served Mexican readers in the Southwest, are located in the Basave collection in the Biblioteca de México at the Ciudadela in Mexico City. The New York Times proved to be the most reliable source for events in the United States. 



\section{Index}

Anarchy, 43-44, 71-73

Attitudes toward emigration: Mexico, 57-59, 103-5; United States, 20-22, $98,124-25,131-38$

Border Patrol, 84

Brigadas de la Cruz Azul (Brigades of the Blue Cross), 106, 115-6, 148

Calles, Plutarco, 73, 75

Carranza, Venustiano, 57-61

Catholic Church in United States, 123-24

Clark, Victor, 26, 28-29

Comisiones Honorificas (Honorary Commissions), 106, 116, 148

Consuls, Mexican, 32-33, 65-69, 106-7, 113-15, 148-49. See also Mexico, government policy

Coolidge, Calvin, 137-38

Coyotes. See Labor recruiters

Díaz, Porfirio, 5, 30, 32

Dillingham Commission, 25, 33-34

Ejidos, 2, 5-9, 72

Emigrants: assimilation of, 92-93; demographic profile of, 82 ; motives of, $41-43,62,74-78,80-82$; occupational profile of, 82-83; settlement patterns of, 26-27,
91-92; view of United States,

78-80, 145-47. See also

Employment patterns in United States

Employment patterns in United States, 19-20, 24-27, 45-49, 84-87, 125-27

Food, 4-5, 41-42, 73

Gamio, Manuel, 9, 10, 87, 90, 93, 103-4, 117

Great Depression, 144-45

Hacienda, 2-3 , 4, 39-41

Honorary Commissions. See Comisiones Honoríficas

Hoover, Herbert , 127-28, 140-42

Immigration Act of $1885,28,34$

Immigration Act of 1903, 34

Immigration Act of 1907, 34

Immigration Act of 1917, 46-48

Immigration Act of 1921, 83

Immigration Act of 1924, 83-84, 124-25

Inflation, 42

Investments in Mexico, 29

Labor recruiters, 27-29, 84-85

Loyo, Gilberto, 80, 105 
Madero, Francisco, 31, 38-39, 55-57

Mexico, government policy, 31-33, 55-57, 59-66, 107-13, 116-18, $139,149-50$.

See also Consuls, Mexican

Migration Law of 1908 (Mexico), 107

Migration Law of 1926 (Mexico), 107

Migration Law of 1930 (Mexico), 107-8

Obregón, Alvaro, 58, 73, 98-103, 105-6, 117

Population, 9-10

Portes Gil, Emilio, 73, 117, 139

Protestant missionaries, 45, 90-91, 121-23

Railroads, 13-17

Recession of 1907,32

Recession of $1921,97-99$

Repatriation, 99-103, 112-13, 145-48, 150-51
Restriction of immigration, 135-36. See also Attitudes toward emigration; United States, government policy

Selective Service Act of 1917, 49-51, 68-69

Special Mexican commissioners, 99-101. See also Mexico, government policy.

Statistics of emigration, 12, 29, 32, $34-36,40,52-53,93-95$

Taylor, Paul S., 26, 92

United States, government policy, $33-34,44-48,51-52,127-31$, 138-42

Wages: in Mexico, 10, 14, 17, 73-74, 87; in United States, 22-23, 27, 45, 73-74, 82, 87-89

Welfare services, 90 



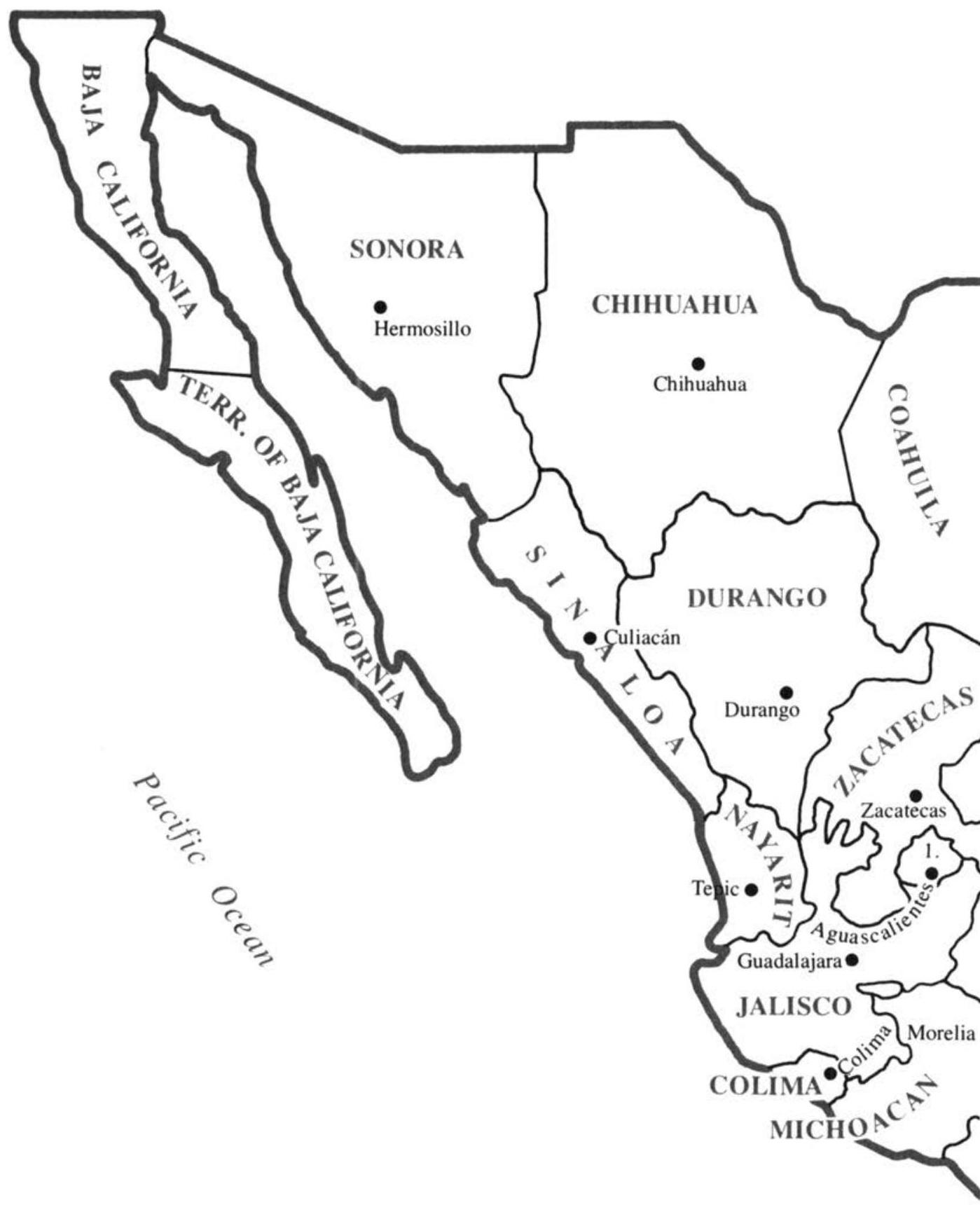

Mexico, 1931 
— State Boundaries $\star$ National Capital $\bullet$ Capital Cities

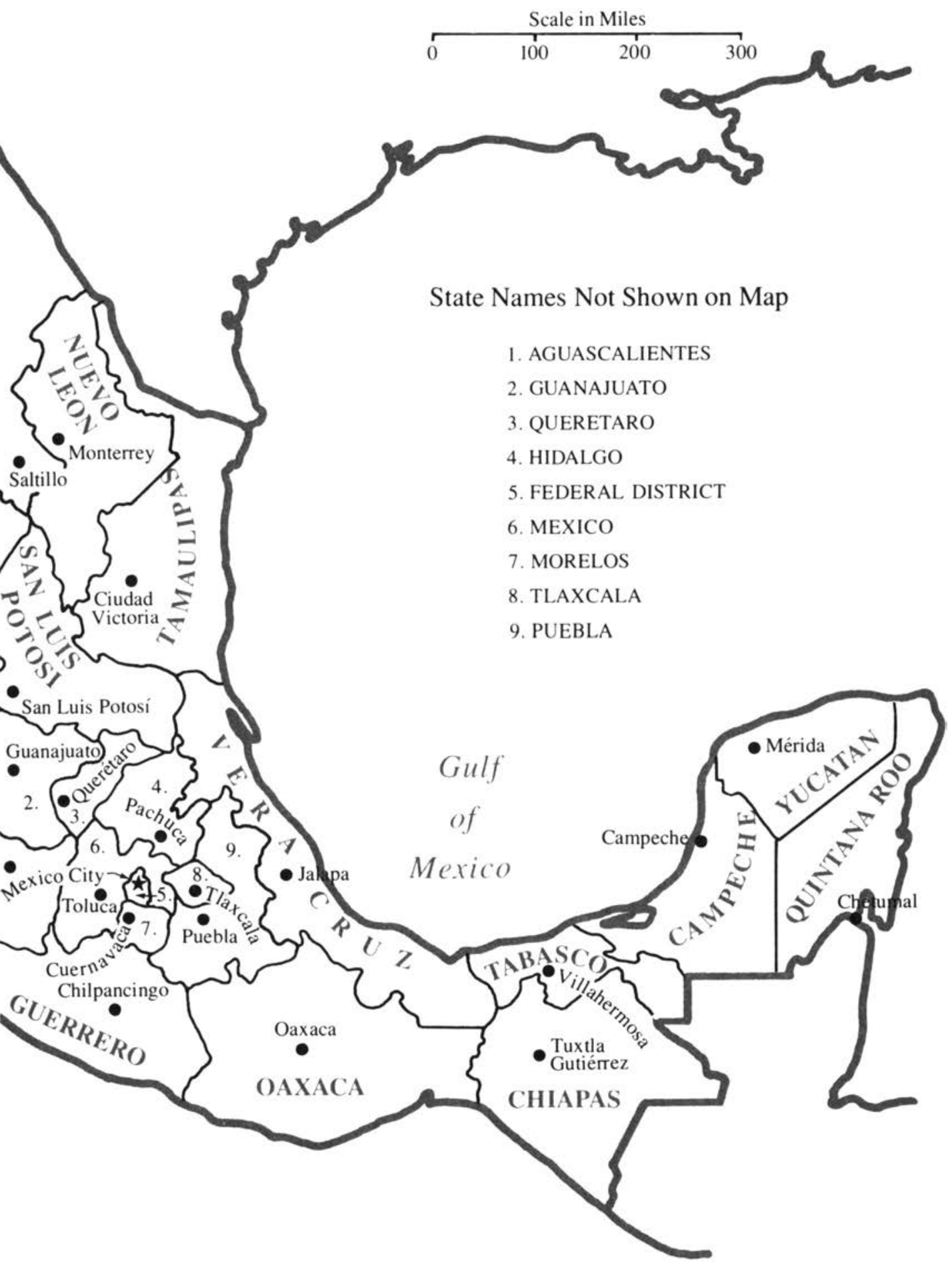


